\title{
Life on Jackson Creek, Smith County, Texas: Archeological Investigations of a 14th Century Caddo Domicile at the Leaning Rock Site (41SM325)
}

Mark Walters

Heritage Research Center, Stephen F. Austin State University

Leslie G. Cecil

Department of Anthropology, Geography, and Sociology

Linda S. Cummings

J. Phil Dering

Jeffery R. Ferguson

See next page for additional authors

Follow this and additional works at: https://scholarworks.sfasu.edu/ita

Part of the American Material Culture Commons, Archaeological Anthropology Commons, Environmental Studies Commons, Other American Studies Commons, Other Arts and Humanities Commons, Other History of Art, Architecture, and Archaeology Commons, and the United States History Commons

Tell us how this article helped you.

This Article is brought to you for free and open access by the Center for Regional Heritage Research at SFA ScholarWorks. It has been accepted for inclusion in Index of Texas Archaeology: Open Access Gray Literature from the Lone Star State by an authorized editor of SFA ScholarWorks. For more information, please contact cdsscholarworks@sfasu.edu. 


\title{
Life on Jackson Creek, Smith County, Texas: Archeological Investigations of a 14th Century Caddo Domicile at the Leaning Rock Site (41SM325)
}

\author{
Authors \\ Mark Walters, Leslie G. Cecil, Linda S. Cummings, J. Phil Dering, Jeffery R. Ferguson, Michael D. Glascock, \\ Timothy K. Perttula, LeeAnna Schniebs, Harry J. Shafer, Jesse Todd, and Chester P. Walker \\ Creative Commons License \\ (c) (1) (9)
}

This work is licensed under a Creative Commons Attribution-NonCommercial 4.0 International License 


\title{
Life on Jackson Creek, Smith County, Texas: Archeological Investigations of a 14 th Century Caddo Domicile at the Leaning Rock Site (41SM325)
}

\author{
Mark Walters \\ with contributions from Leslie G. Cecil, Linda Scott Cummings, J. Phil Dering, \\ Jeffrey R. Ferguson, Michael D. Glascock, Timothy K. Pertula, LeeAnna Schniebs, \\ Harry J. Shafer, Jesse Todd, and Chester P. Walker
}

HISTORY OF THE LEANING ROCK SITE (41SM325)

The 14th century Caddo Leaning Rock site was initally discovered in the Fall of 2004. It was located during reconnaissance to search out a location for the survey portion of the Texas Archeological Society's Academy 101 held in Tyler in February 2005 (Pertula and Walters 2007). This was not a formal survey with transect lines; nor one using regularly spaced shovel tests, but was rather more of a "windshield" type survey, consisting of driving across pasture lands looking at gopher mounds and checking for evidence of archeological deposits on likely looking landforms.

In this area, landform and soil type seem to be the major determining factors in locating Caddo sites. The sandy soils in the scattered gopher mounds appeared almost white, especially in droughty conditions that prevailed at the time, causing an area with darker mounds of soil to catch my attention. Pocket gophers (G. breviceps) can play havoc with buried archeological deposits but can also be useful in bringing buried soils along with archeological materials to the surface from their underground tunnel system. While this dark area could have been the result of past historic land clearing and burning activities, a closer inspection revealed burned bone, mussel shell, and Caddo sherds mixed in the dark brown soils in the scattered gopher mounds.

The next step was to record the site with the State of Texas, obtaining the trinomial 41SM325. It is common practice to also give sites informal names and after recording several hundred sites, selecting a name becomes a challenge. One large sandstone slab, part of the R-horizon that is exposed around the margins of Leaning Rock, was unearthed during prior landclearing activites and pushed up against a lonely pine tree on the northern margins of the site; consequently the nom de plume "Leaning Rock."

\section{NATURAL SETTING}

Northeast Texas is a region in the northeast corner of the state of Texas, lying within the Gulf Coastal Plain. Smith County is in the central part of northeastern Texas, and the Leaning Rock site (41SM325) lies in the eastern portion of Smith County.

The regional climate is warmer and wetter than most of Texas and its geography is more hilly and forested. The modern average daily temperature maximums are 75.5 degrees, daily minimums are 51.7 degrees, and the average tempreture is 63.6 degrees. This masks the fact, as the area Chamber of Commerce fails to advertise. 
that this portion of Texas has uncomfortably hot and humid summers, mostly due to moist tropical air from the Gulf of Mexico, Precipitation averages around 44 inches a year with $50 \%$ or more falling between April and September, the peak growing season for most crops (see Perttula and Nelson [2004:7-10] for a more detailed study of past climates in Northeast Texas).

The vegetation in this part of Northeast Texas is the Pineywoods, a mixed forest of deciduous and coniferous flora. The Pineywoods cover 23,500 miles $^{2}\left(60,900 \mathrm{~km}^{2}\right)$ of gently rolling or hilly forested land. These woods are part of a much larger region of pine-hardwood forest that extends into Louisiana, Arkansas, and Oklahoma. This forest is dominated by several species of pine, including Longleaf Pine (although absent this far north in the Pineywoods), Shortleaf Pine, and Loblolly Pine, as well as several varieties of hardwoods including Hickory and Oak.

Leaning Rock is situated on a finger ridge of an interstream divide in the uplands. At the crest of the divide the elevation is $485 \mathrm{ft}$. amsl, Jackson Creek at $377 \mathrm{ft}$ amsl in elevation is on the west side of the divide, while $1 \mathrm{~km}$ to the east and running parallel to it is Caney Creek. The elevation in the center of Leaning Rock is $405 \mathrm{ft}$ amsl. The finger ridge covers approximately $6500 \mathrm{~m}^{2}(1.6 \mathrm{acres})$, and drops off sharply on the west and south into the Jackson Creek floodplain. Present day use of the site is improved pasture sodded with Bahia grass.

Soils at the Leaning Rock site are part of the Cuthbert series: gently sloping soils that formed under dominately pine forests on uplands. They are well drained sandy soils that have a loamy subsoil. A typical pedon of Cuthbert fine sandy loam (Hatherly 1993:75) is comprised of the following soil horizons:

A- 0 to 4 inches $(0-10 \mathrm{~cm})$; dark brown (10YR4/3) fine sandy loam;

E-4 to 9 inches $(10-23 \mathrm{~cm})$; yellowish brown (10YR5/4) fine sandy loam;

Bt $1-9-17$ inches $(23-43 \mathrm{~cm})$; red $(2.5$ YR $4 / 6)$ clay.

At Leaning Rock, the soils vary in depth and composition. Around the southern and western margins, toward the Jackson Creek floodplain, the slope increases dramatically and the soils are thinner and contain more angular sandstone and ironstone gravels. Also around the margins of the landform are exposed sandstone deposits. Towards the north, starting around the middle of the excavation units, the soil has less gravel and the depth to the red strongly acid clay loam is greater than $1 \mathrm{~m}$. There are few artifacts in this area and the Caddo could have had their agricultural fields here to take advantage of the deeper, sandier soils.

Not all similar landforms in this area have deep soils, many being gravelly with exposed clay subsoils, and these seem to have been avoided by the Caddo. The surface of Leaning Rock is stable; that is, weathering has been the dominant process and material has not been transported nor deposited (Holliday 1992:206) onto the site. The dark soils associated with the prehistoric Caddo occupation at Leaning Rock are the result of organic clastic particles transported to the site. Organic material or soil organic matter (SOM) is the accumulation of dead plant and animal remains, partially decayed plant and animal residues, and humus. SOM accumulates on the surface and over time mixes with the parent material to produce the A-horizon, and is sometimes transported downward into the parent material and accumulates in subsurface horizons (Holliday 1992:196).

It is difficult to judge the impact that the development of Caddo agriculture may have had on the landscape at Leaning Rock. Farming is the replacement of the natural vegetation community with some sort of artificial vegetation: an agroecosystem (Holliday 2004:324). There are far-reaching effects brought on by this activity, including loss of soll organic matter: the reduction of nitrogen and phosphorus; erosion by wind 
and water due to loss of the original plant cover; increased competition from invasive plants; and reduction of soil porosity and infiltration. Soils formed under forest conditions, such as those at Leaning Rock, have shallow A-horizons and are subject to leaching and erosion once the fragile surface layer is removed. We know the Caddo were sedentary but were also mobile on some basis, perhaps generationally, but we do not fully understand the reasons behind their settlement dynamics. This strategy is unlike slash-and-burn cultiva tion in which the forest is cleared by buming to provide lacking nutriments. Slash-and-burn cultivation is a shifting system of agriculture in which field (not necessarily villages) systems move over time as forest is cleared, exploited, then left fallow, allowing the forest to regenerate and soils to replenish themselves. However. it is a daunting undertaking to approach a 100 year old oak with a modern chainsaw, much less with a small hand-sized stone celt or axe. More realistically the Caddo probably girded large trees by chopping or burning. Once the tree was dead, even though still standing, sunlight would be allowed in for crops, plus the dead tree would have provided a long-term supply of dry wood for cooking fires. There seems to be no evidence that the Caddo during this time period regularly returned to reclaim fallow fields. Why the Caddo abandoned Leaning Rock may have had as much to do with social reasons as it did with agricultural practices or paleoenvironmental changes.

Two soil samples from Leaning Rock were submitted to the Texas A\&M University Station at Overton, Texas, for pH analysis. Sample \#1 was taken at N130/E100 (20-25 cm bs), an area outside a midden area. The soil was a dark yellowish-brown sandy loam $(10 Y R 3 / 6)$ with a medium pH of 5.56. Sample \#2 was taken at N110/ E90, within a midden deposit, at a depth of $20-25 \mathrm{~cm}$ bs. Soils at this depth were a very dark brown sandy loam (10YR2/2) and contained burned bone and charcoal flecks. The pH of this sample was 6.47 , slightly acid. It has been demonstrated that "activity centers have higher $\mathrm{pH}$ values compared with site peripheries, further

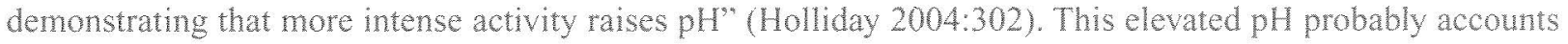
for the excellent preservation of plant and animal remains at Leaning Rock. These soils have been described as "anthrosols" which typically have significant chemical inputs as well as obvious physical changes resulting from human activities (Holliday 2004:26).

As previously mentioned, Leaning Rock is located on Jackson Creek, one of the minor tributaries of Prairie Creek which drains in a northeastern direction some $15 \mathrm{~km}$ to the Sabine River. Jackson Creek, a first order stream (Leopold et al. 1965:134), is $3.5 \mathrm{~km}$ in length and originates in a small natural upland pond. During excavations at Leaning Rock in 2005, a year with below normal rainfall, Jackson creek stopped flowing and only had water in small pockets. The headwaters of Prairie and Jackson creeks form a divide. Streams south of this divide flow in a southeastern direction into Mud Creek and eventually the Angelina River, while those to the north flow in a northeastern direction toward the Sabine River.

For some reason the Caddo in this part of the Sabine River basin during the time period (A.D. 1200-1400) when the Leaning Rock site was occupied seemed to have deliberately chosen these headwater areas for places to live. Such settings resemble the coves and hollows that my ancestors, the Southern Highlanders, chose to settle on in the Appalachian Mountains in the eastern United States. There are numerous recorded Caddo habitation sites in the immediate area in similar settings. Artifacts from these Caddo sites indicate that these nearby sites were generally contemporous with the Leaning Rock Caddo occupation.

Jackson Creek probably provided adequate drinking water, possibility supplemented by small seeps and springs that the Caddo may have utilized along the margins of the valley. It is certainly possible that the Caddo could have utilized their ceramic jars to catch runoff from the eves of their houses, as early Anglo-American settlers used rain barrels. Our modern day water usage leads to a misconception concerning the amount of water that is actually needed for human survival. Daily water requirements vary depending on body weight, exercise. 
etc., but for a 140 pound person, and moderate exercise, the daily requirement is $2.5-3$ liters (or approximately 85-101 flud ounces)(Gleick 1996).

Jackson Creek or the upper reaches of Prairie Creek could not have supported much in the way of aquatic resources. Nevertheless, the Caddo folks at Leaning Rock evidently knew about such resources, judging from the recovery of large mussel shells and large fish bones found in the midden (see Schniebs and Todd, this article), and made trips, probably to the Sabine River, to obtain such resources.

\section{ARCHEOLOGICAL INVESTIGATIONSAT LEANING ROCK}

Following the discovery of the Leaning Rock site, I decided to conduct limited investigations for the purpose of gaining a better understanding of how the Caddo people were living in this portion of East Texas. Caddo sites in this area with middens and well preserved plant and animal remains are rare and few have been studied to any degree.

Since this was the winter season and pasture grasses at the site were dormant, the site was first disked to expose as much of the surface as possible. A $6 \mathrm{ft}$. tandom disk behind a tractor was used to chop up the grass cover. Following a rain, the area was marked off in $5 \times 5 \mathrm{~m}$ blocks and all the surface prehistoric artifacts were collected and tabulated for each block (Figure 1).

Disking also allowed the areas of darker soil to be mapped (see Figure 1). During the 2005 Tyler TAS Academy Survey (Pertula and Walters 2007), a 1 x $1 \mathrm{~m}$ test unit was opened by TAS members Bo Nelson and Bryan Boyd. (Bryan is also a member of the Texas Archeological Stewardship Network and Bo is an advisor to that group.) Test Unit 1 revealed midden soils extending from the surface to $40 \mathrm{~cm}$ bs. The majority of the artifacts came from the midden. Artifact density was high at 1617.3 artifacts per $\mathrm{m}^{3}$, including 214 sherds and 468 pieces of bone. A total of $29.6 \mathrm{~g}$ of charred nutshell were collected from the archeological deposits and a radiocarbon date from nutshell collected from $30-40 \mathrm{~cm}$ bs yielded calibrated age ranges at 2 sigma of AD 1200-1320 and AD 1350-1390(Beta-204576).

Following the Academy Survey, remote sensing (see Walker, this article) was conducted in the Spring of 2005. Preliminary results of that work were inconclusive, but additional processing and mulling over the remote sensing data has proved to be informative. Work continued with additional units excavated around TU I exposing Feature 1, a hearth.

In all, thirteen test units with a total of $30 \mathrm{~m}^{2}$, or $11.35 \mathrm{~m}^{3}$, were excavated at Leaning Rock (Figure 2). In addition, six shovel tests were excavated for an additional $0.74 \mathrm{~m}^{2}$ or $0.44 \mathrm{~m}^{3}$ of archeological deposits.

Extremely dry soll conditions made the identification of features difficult during the excavations. Units were excavated to the bottom of the midden and work was terminated at this point with the hope that the site would receive rainfall, allowing features (if present) to be identified. However, the dry conditions continued through the remainder of 2005 and the decision was made (and seconded by a trip to the by-pass doctors) to cover the excavations with plastic and backfill the units. I am leaving open the possibility of retuming to Leaning Rock in the future, but the present article is a comprehensive report on the work conducted to date at Leaning Rock. 


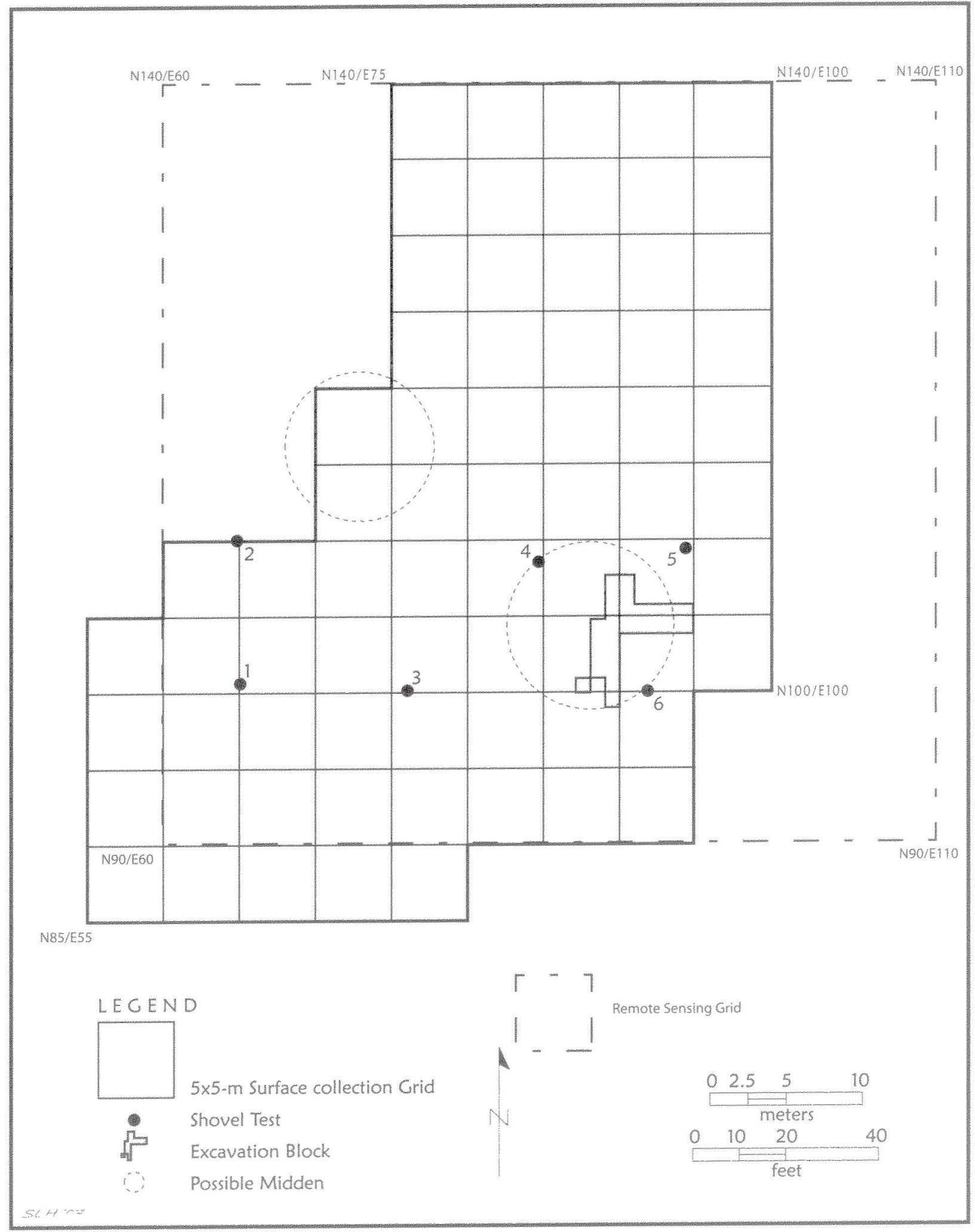

Figure 1. Map with surface collection grid, remote sensing grid, shovel tests, test units/excavation block, and possble midden areas. 


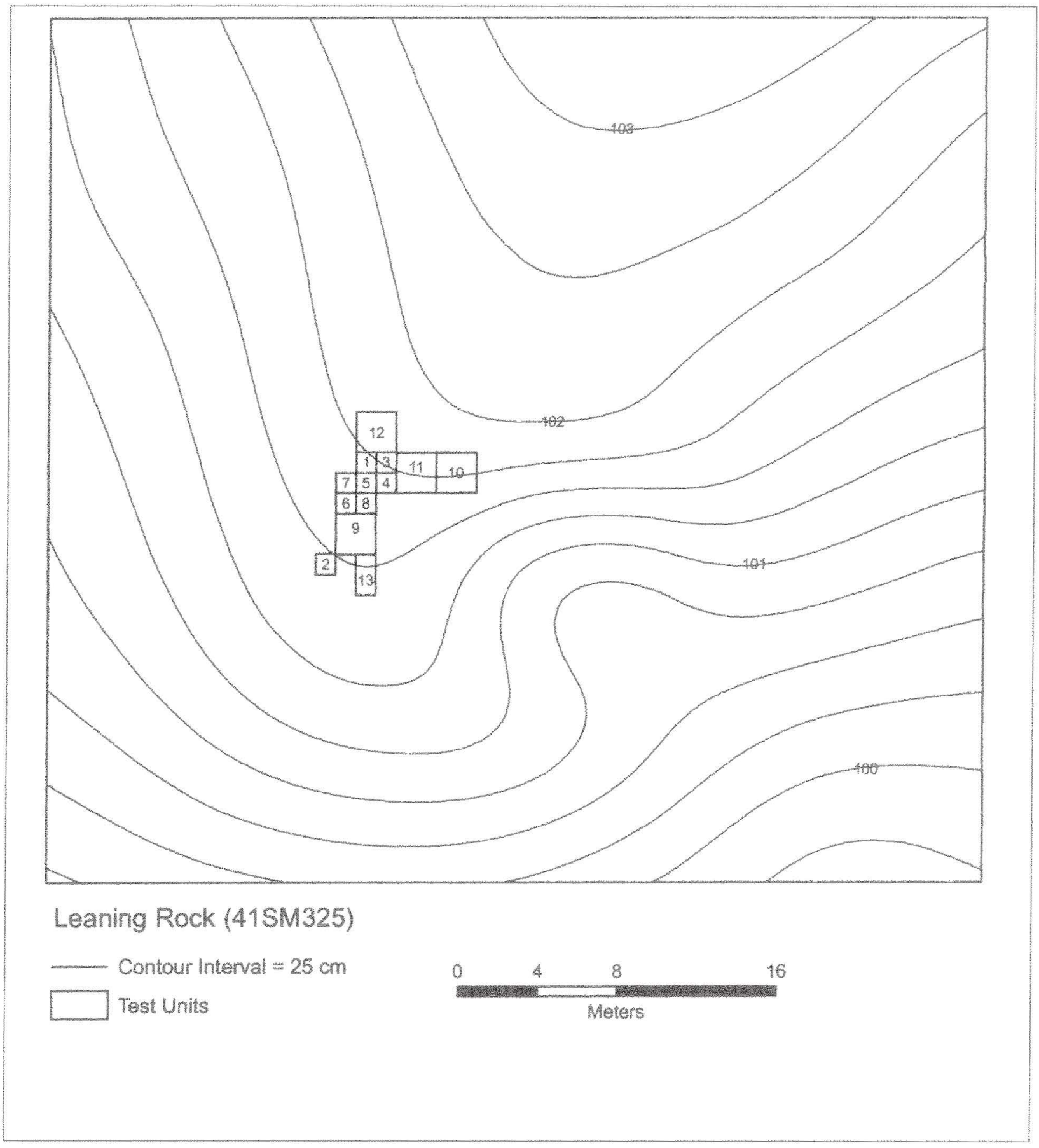

Figure 2. Unit plan map superimposed over site contour map. 


\section{CESIUM MAGNETOMETER SURVEY AT THE LEANING \\ ROCK SITE (4ISM325)}

\section{Chester P. Walker}

\section{INTRODUCTION}

Survey using a cesium magnetometer was conducted in order to identify potential prehistoric Caddo archeological features at the Leaning Rock site (41SM325). Data was collected with a GeoMetrics 858 dual sensor cesium magnetometer and a GeoMetrics 856 portable proton procession magnetometer base station. Two grids totaling $2,500 \mathrm{~m}^{2}(0.6$ acres $)$ were collected. This section presents the findings from this survey and compares it to findings from the archeological excavations (ground penetrating radar studies were done at Leaning Rock by Bergstrom et al, see Appendix 1).

\section{AREAS OF INVESTIGATION AND GENERAL METHODOLOGY}

A Sokkia set 5 a total data station (TDS) was used to lay out a $50 \times 50 \mathrm{~m}$ collection area that was divided into two $50 \times 25 \mathrm{~m}$ grids. The site datum was used (N100 E100) and the southwest corner of the area was N90 E60. Collection area comers were laid out using the TDS. Tapes were used to place stakes at $10 \mathrm{~m}$ intervals on the north-south sides of the collection grids (Figure 3). A 10 minute data set was recorded and later post-processed using data from the CORES web site and Thales software application Mobile Mapped Office. The result is a sub-meter (or better) UTM reading.

\section{SUMMARY OF TECHNICAL INFORMATION}

Archeo-geophysics employs a range of techniques for the non-destructive prospecting of archeological deposits. These techniques have been developed for a range of applications, mostly geological in nature, but have been adapted for specific use in archeology through rigorous field collection techniques and unique data processing programs specifically developed for archeongeophysics.

In general, all techniques map, record, or sense different variables or properties of the soll and the objects within the soil. The instruments are differentially affected by variables such as moisture,

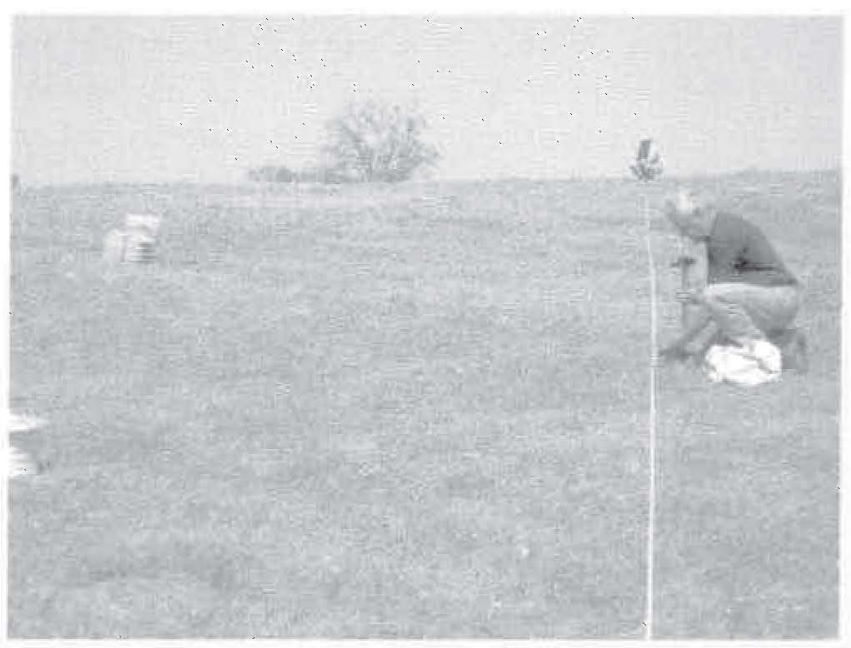

Figure 3. Mark Walters establishing the site collection grid at the Leaning Rock site. the natural iron content of the archeological sediments, metal trash or debris, and transmission of signals such as cell phones and transmission lines. Data collection is also impacted differently for each of the geophysical instruments by physical impediments such as trees, pavement. fences, and vegetation. 
Magnetometer and gradiometer surveys are non-invasive and passive, and measure slight variations in the magnetic properties of soil. Magnetometers have become the primary tool for the archeo-geophysicist working on Caddo sites, as well as other sites in Texas, in part due to the fact that large sets of data can be collected and processed quickly and when conditions are right magnetometers have proven useful in locating negative relief features such as pits and post holes as well as thermally-altered features such as burned clay or rock hearths and burned structures (Bruseth and Pierson 2004; Creel et al. 2005; Frederick and Abbott 1992; Lockhart 2007; Schambach 2001, 2002; Schambach and Lockhart 2003; Walker and Perttula 2007a, 2007b; Walker and Schultz 2006; Walker et al. 2003).

Magnetometers record the minute fluctuations that sediments and objects have on the earth's magnetic field. This is known as induced magnetism because the object does not maintain its own magnetic field. If the effects of this induced magnetism are strong enough compared to the surrounding soil matrix, pit features or post holes can be identified or resolved in the geophysical data. A second type of magnetism called remnant magnetism is created when an object maintains its own magnetic field. In the case of prehistoric archeology, this occurs when objects are thermally altered, thus creating a magnetic state called thermoremanent magnetism (Kvamme 2006b:207).

\section{FIELD METHODS}

The specific settings used for the instruments differ greatly depending on the dimensions and nature of the target; however, there are a few general concepts of data collection that apply in all cases. The density of the data set is controlled by two factors: (1) traverse interval: the distance between the passes the instrument makes as it zigzags back and forth across the collection area; and (2) sample interval: the distance between readings the instrument records as it passes along each traverse. There are standard starting points for these settings, but ultimately this depends on many factors, including the size and depth of the target, the nature of the sediment matrix, land use of the collection area, duration of the survey, as well as the investigative scope of the research design. In the case of the Leaning Rock geophysical investigations, the scope of the research design was to attempt to locate and identify magnetic anomalies and/or areas of magnetic enhancement within the boundaries of the known archeological deposits, and provide initial archeological interpretations of the size and likely character of these targeted anomalies.

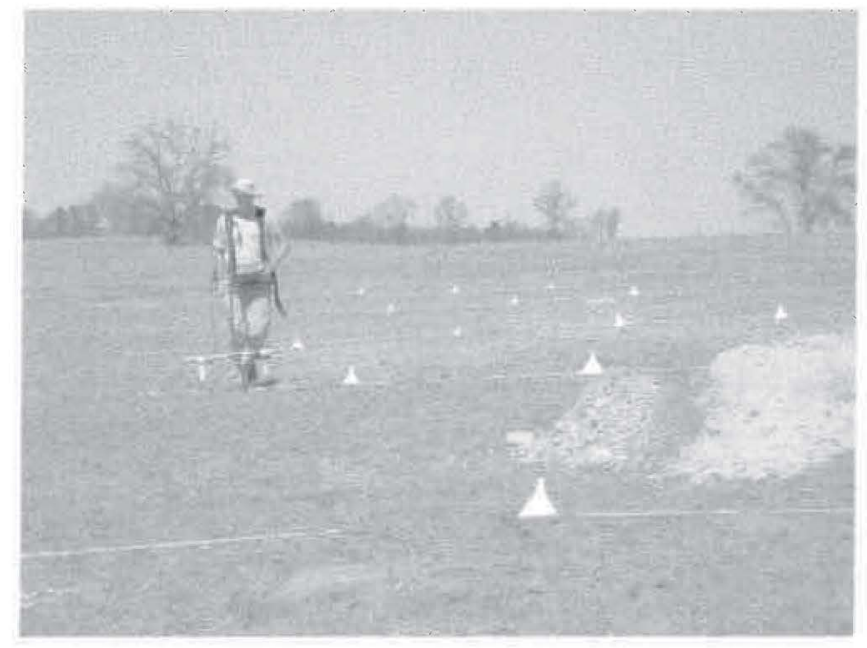

Figure 4. T. Clay Schultz collecting magnetic data at the Leaning Rock site.
Magnetic data was collected using a $1 \mathrm{~m}$ traverse interval with a $0.5 \mathrm{~m}$ sensor separation, resulting in two lines of data per $m$. The sample interval was 10 readings per second and was collected in a zigzag or back and forth pattern. Data was collected along the north-south axis of the grids. Ropes were placed on $10 \mathrm{~m}$ intervals running east to west. A plastic cone was moved in $1 \mathrm{~m}$ increments along the ropes to guide the surveyor. A fiducial mark was entered into the data set every $10 \mathrm{~m}$ as the surveyor passed over the eastwwest running ropes (Figure 4). 


\section{DATA PROCESSING}

All data were processed and filtered to remove extraneous false readings (spikes and drop-outs). Processing levels the data sets so adjacent grids are combined into a single image with no "grid lines." Data sets were processed to enhance the visibility of the target features at Leaning Rock through statistical manipulation of the recorded data as well as through image processing of the image file output.

The general goal of data processing is to lessen the effects of background "noise" and to enhance the quality of the "signal" or "target." In field geophysics in general, and archeo-geophysics in particular, the term noise is used to discuss any return that is not thought to be a direct result of the object under investigation: the latter is referred to as the "target" or "signal," and may include cultural features or anomalies as well as areas of magnetic enhancement that are thought to be the product of a past human occupation. Hence, in some cases what is discussed as noise can in another case become the signal or target (Milsom 2005:13-14). Accuracy of the geophysical readings are not as important for resolving targets as is the contrast between the target and its surrounding matrix.

I follow the dictates of Kvamme (2006c:236) in the general approach to data processing of geophysical data from the Leaning Rock site, specifically (a) collect high-density geophysical data over a large area; (b) computer process the magnetic data to identify and clarify regular and culturally-interpretable spatial patterns; and (c) employ pattern recognition principles to aid in the interpretative process. "In general, anomalies exhibiting regular geometric shapes (lines, circles, squares, rectangles) tend to be of human origin" (Kvamme 2006c:236). The major data processing techniques are outlined in Table 1.

Table 1. Data processing steps for magnetometer data at Leaning Rock (41SM325).

Clip at 3 SD

Clip at $3 \mathrm{SD}$

DeStripe Median Traverse: Grids: All

Low pass Gaussian filter: Window: 3 × 3

After each processing step the results are closely compared to their previous state to assure that data manipulation is not in fact decreasing the clarity and quality of the data, thus avoiding remote sensing patterns that are simply the product of data processing. Clipping replaces all values outside a specified minimum and maximum range. These minimum and maximum values are specified in either absolute values or \pm Standard Deviations (SD). This process is used to remove extreme data point values and aids in normalizing the histogram of the data. Archeological details are subtle, and having a normal distribution of data allows the fine detail to show through with clarity.

Destriping is a process used to equalize the underlying differences between grids caused by instrument drift, inconsistencies during setup, delays between surveying adjacent grids, or heading error from magnetic instruments. The mean, mode, or median of each grid or traverse is subtracted from the grid or traverse, effectively zeroing the mean, mode, or median. When the mean is used, thresholds are set to exclude extreme data points.

High and low pass filters are used to remove high or low frequency components in a geophysical survey. A high pass filter calculates the mean of a window of a specified size, then subtracts this mean from the center 
value. A low pass filter calculates the mean of a window of a specified size, and replaces the center value with the mean. Either filters can use Uniform or Gaussian weighting. With Uniform weighting means, all values within the window are given equal weight. Gaussian weighting gives a higher weight to values closer to the center of the window. One of the most common applications of the high pass filter is to remove the geological background from resistivity data (Somers 2006:118-119). Low pass filters are more commonly applied to lessen the effects of background noise. Both filters should be used with caution and close attention should be made to their resulting affects, thus assuring that no processing artifacts are created, or no significant anomalies removed as a result of their application (Kvamme 2006c).

After data was processed in ArchaeoSurveyor 2.0 , images were imported into ArcGIS 9.2 (Figure 5). The image was geo-referenced using the site grid. Archeological plan maps were then digitized and overlaid on the remote sensing.
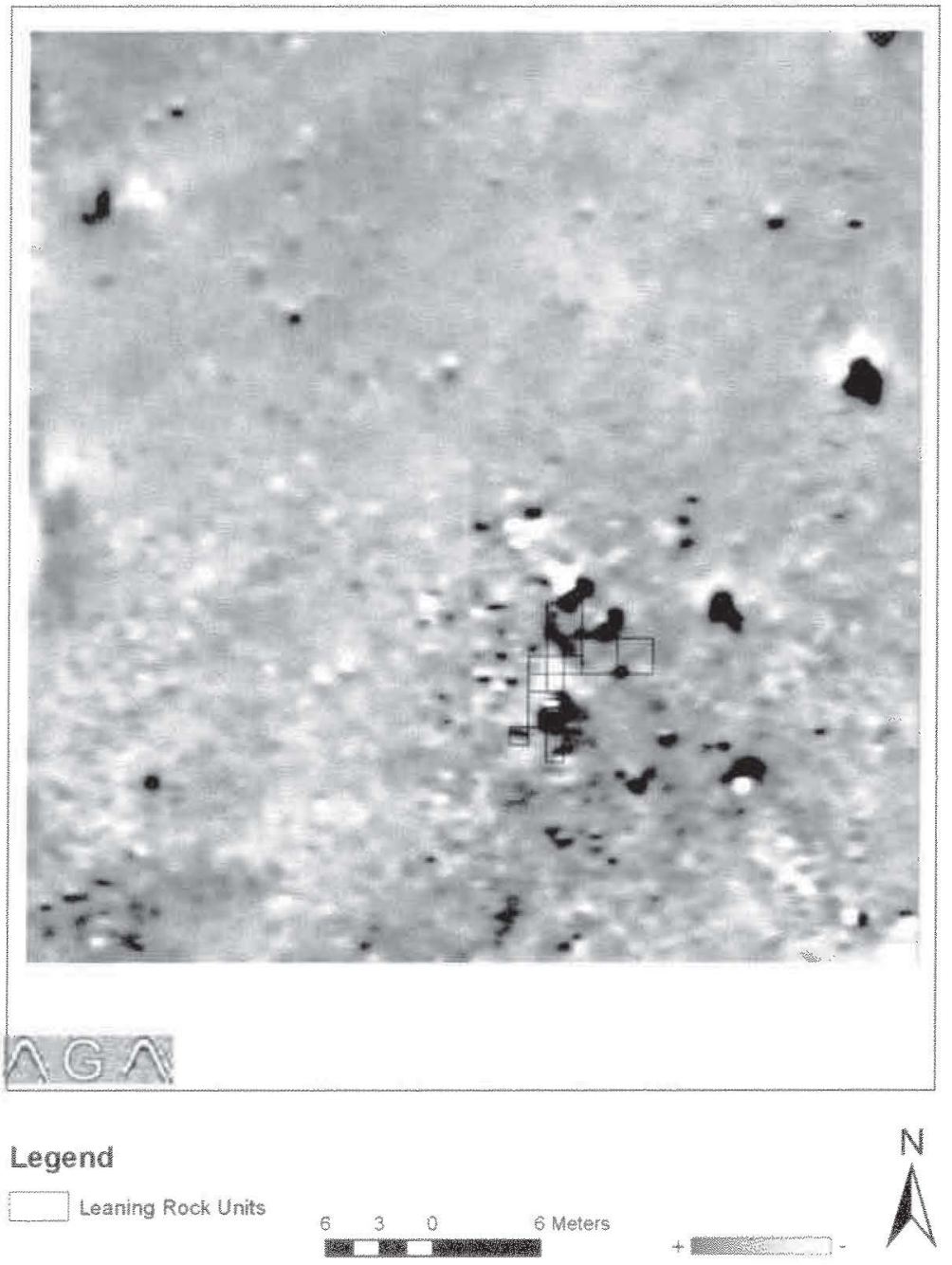

Figure 5. Magnetometer results after ArchaeoSurveyor 2.0 processing and geo-referencing at the Leaning Rock site.

\section{RESULTS}

The most obvious trend in the magnetometer data from the Leaning Rock site is the area of general magnetic enhancement located in the southeastern portion of the collection area (Figure 6). This area corresponds approximately to the area of highest artifact densities. This pattern has been observed in magnetometer data sets at other Caddo sites (see Walker and Perttula 2007b), where it appears that densities of pottery sherds and burned organic materials raised the magnetic background. It is unclear what exactly is causing this magnetic enhancement: the clay bodies of the sherds themselves, the high densities of such sherds in subsurface contexts, or the simple fact that they have been fired? Lipo et al. (2004:80) have also suggested that "positive magnetization also occurs in organic-rich materials such as midden deposits, as these conditions may cause authigenic mineral growth." Further experiments, and additional geophysical investigations on sites with and without midden deposits, will hopefully resolve the details of this phenomena.

Several dipole returns are scattered across the collection area (see Figure 6). These dipoles are mostly clustered 
in the area of magnetic enhancement discussed above; however, they are not limited to this area. Dipole returns are usually interpreted as metal debris although ground truthing is needed to determine this for certain. Thermally altered rock cooking features can product similar magnetic returns. The magnetic properties of ferruginous materials, especially plinthite, increase significantly when heated, sometimes producing stronger signatures than metal.

Detailed interpretations were not easy at Leaning Rock, primarily because of the small size of identified features. It was not until after excavations had taken place and their findings were plotted onto the magnetometer data (Figure 7) that it was possible to discern the difference between background noise and the archeological data. Even with detailed plots of excavated features it is still difficult to resolve some of the magnetic anomalies.

The area of magnetic enhancement (see Figure 6) corresponds closely to the observed extent of the midden deposits in the southeastern part of

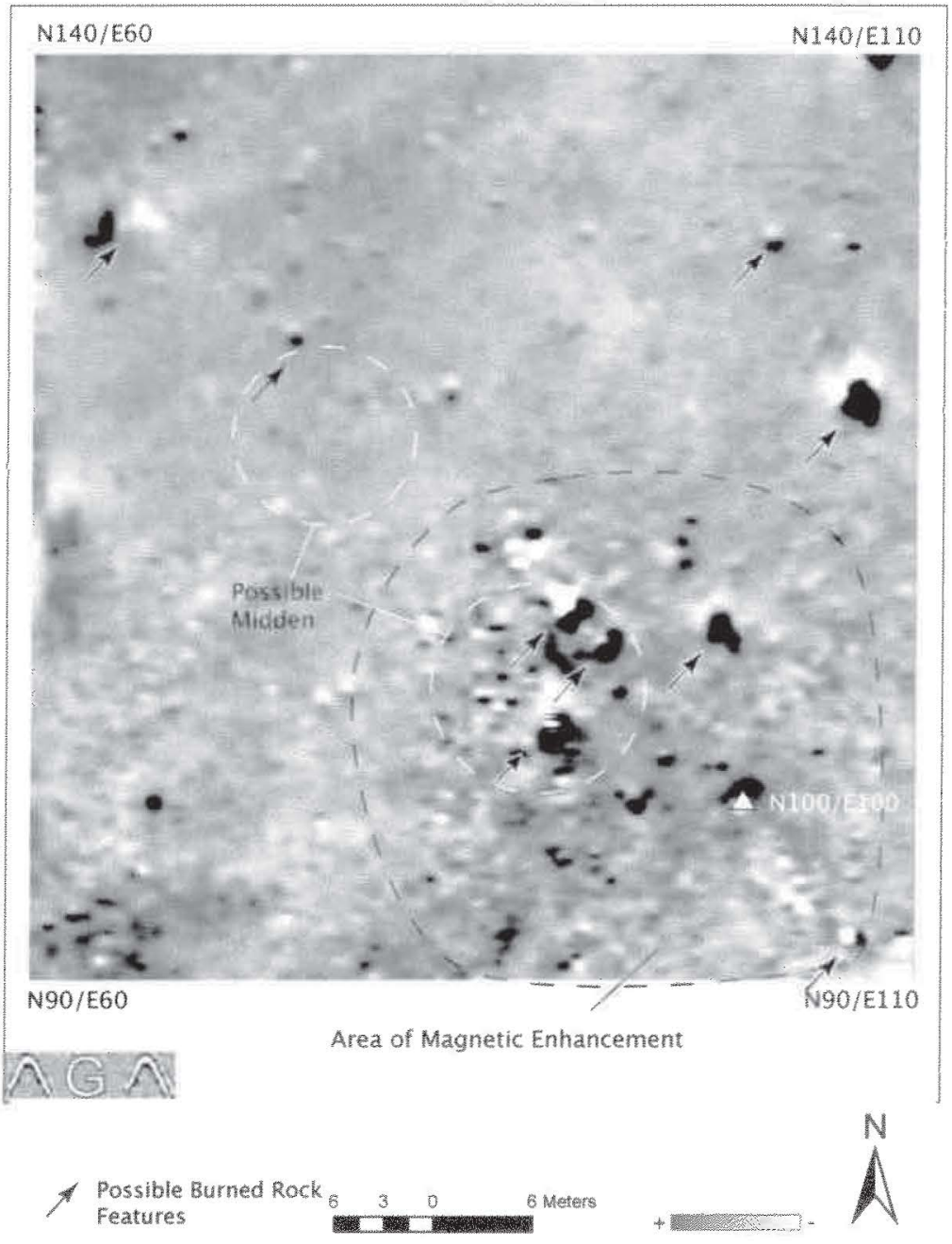

Figure 6. Area of magnetic enhancement at the Leaning Rock site and locations of possible bumed rock features the surface collection grid (see Figure

1). Feature I (see Figure 7) is a hearth feature-with considerable ash-consisting of a $15 \mathrm{~cm}$ thick deposit of compact ash. This feature would likely show up in most saturations, and this feature is clearly apparent as an area of high positive magnetism.

Feature 4 is a possible post from $50-70 \mathrm{~cm}$ bs. It is indicated as a low magnetic return (see Figure 7 ). It is possible that this low magnetic return is caused by the contrast of the strong high magnetic returns located around this feature and is not actually representing the possible post.

Feature $\xi$ is a pit $(50-75 \mathrm{~cm}$ bs) and extends into the north wall of Unit 12. This feature corresponds well with the large positive magnetic anomaly that extends to the northeast from Unit 12 . The magnetic data suggests that Feature 5 is at least $1 \mathrm{~m}$ in diameter (see Figure 7 ).

Feature 6 is a possible post hole that extends from $50-75 \mathrm{~cm}$ bs. This stain corresponds with a small positive magnetic anomaly (see Figure 7). Like Feature 4, it is uncertain if this pattern is indeed the post hole stain or if it is the extension of the large positive magnetic anomaly to the north. 


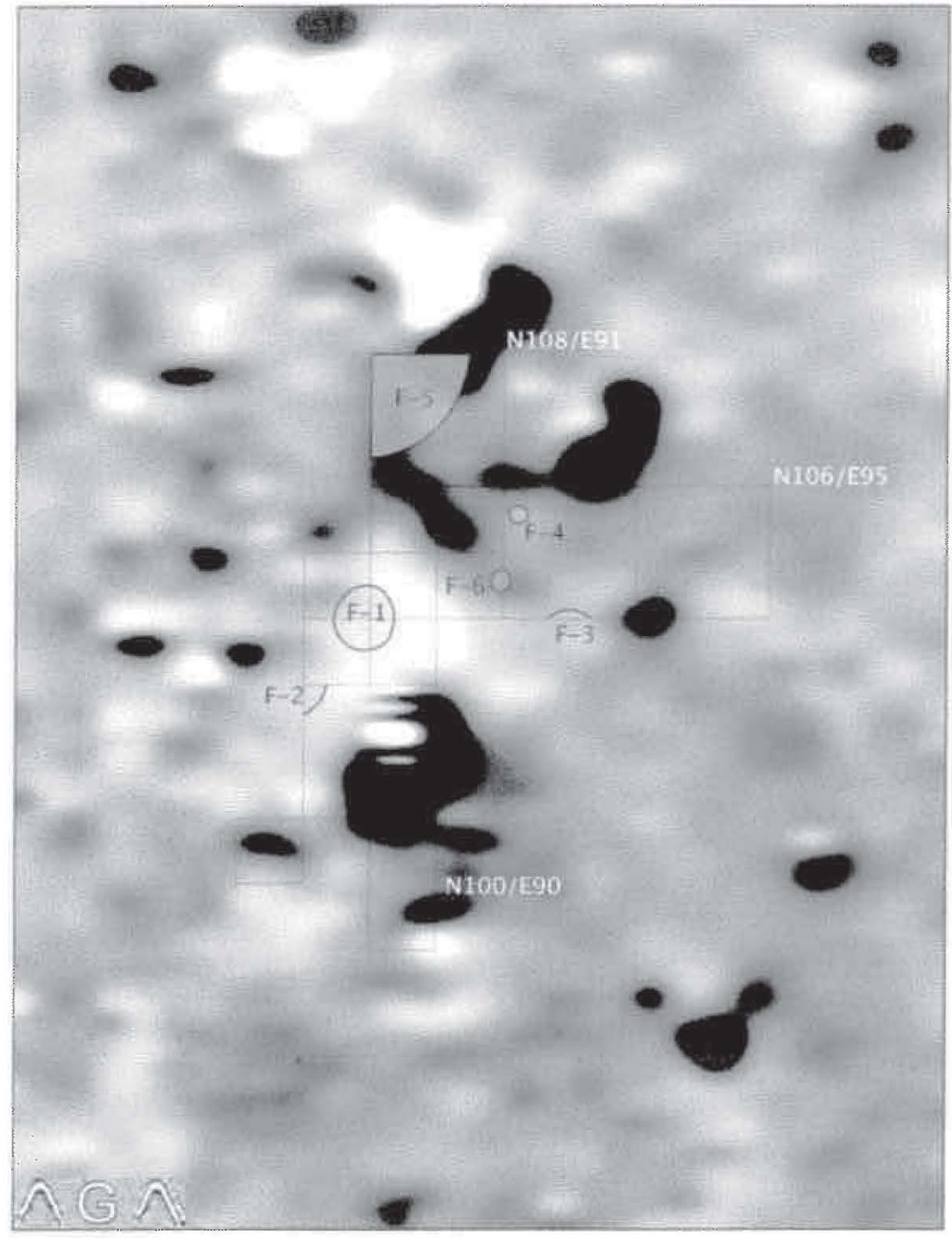

\section{Legend}

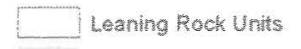

Leaning Rock Foatures

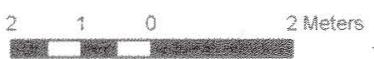

Figure 7. Close-up of magnetic data with block excavations and feature locations.
Features 2 and 3 could not be clearly detected even after they were plotted on the magnetometer data, although they do occur in areas of generally positive magnetism (see Figure 7); neither feature probably contains sufficient burned materials to produce a high magnetic signature. Feature 2 was a shallow pit from $24-34 \mathrm{~cm}$ bs that extends into the west wall of Unit 9. Feature 3 is a deeper pit $(50-88 \mathrm{~cm}$ bs) that extends into the south wall of Unit 11 .

\section{Summary of the Geophysical Findings}

Survey using a cesium magnetometer was conducted in order to identify potential Caddo archeological features at the Leaning Rock site (41SM325). The magnetometer data from Leaning Rock is a good example of the magnetic signature of a small Caddo site in the sandy soil found throughout East Texas. While no clear cut architectural patterns are obvious in the geophysical data from the site, a closer look reveals a fair amount of archeological information. Whether it is caused by the actual magnetic properties of sherds, general magnetic enhancement of anthropogenic deposits, or is a simple geological phenomena, there appears to be an area of magnetic enhancement

that corresponds to the overall distributions of artifacts at this Middle Caddo period residential settlement. Plots of excavation units and features also show that despite the overall noisy nature of the data there indeed are legible and interpretable archeological features present in the Leaning Rock magnetometer data.

\section{FEATURES}

In retospect, all of the features at the Leaning Rock site were probably enclosed in a larger midden feature. The use and strategic placements of middens at habitation sites seems to be one defining factor of Caddo culture. There were six features identifed as a result of investigations at Leaning Rock (Figure 8).

The term midden here refers to a dump for domestic waste relating to day-to-day human life. A refuse heap or 


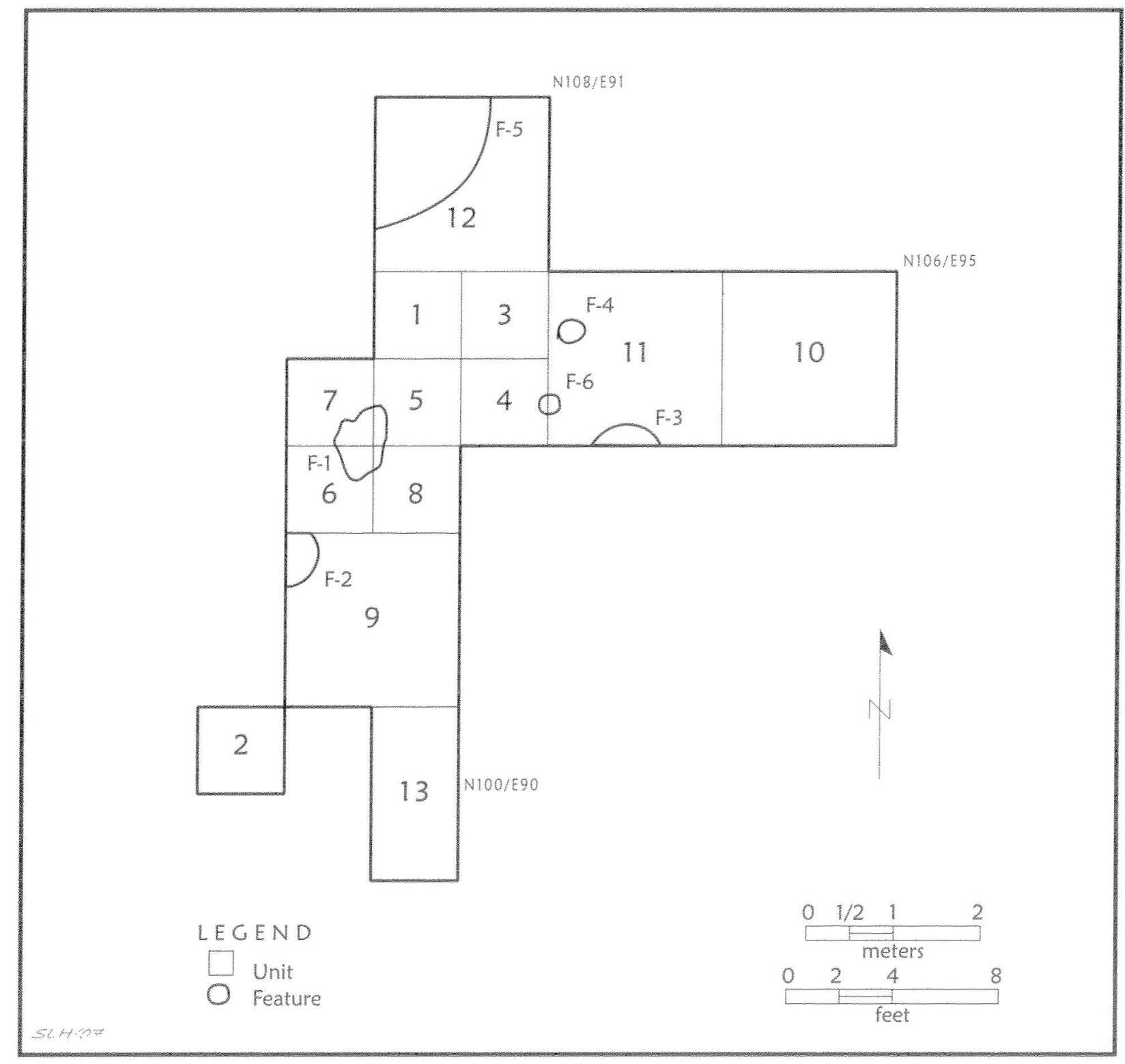

Figure 8. Plan map of excavations with features.

discrete deposit is often referred to as a "kitchen" midden as opposed to helter-skelter disposal of trash. Modern lifestyles minamize the problem of waste with trash pick-up, garbage disposals, and flushing toilets. Also prepackaged foods eliminate the waste that comes from food processing. Middens are useful to archeologists who wish to study the diet and habits of past societies. Middens are a product of the number of people living at a location; the length of time involved; the types and forms of plant and animal products that are brought to a site for processing; and the particular soil processes that influence the preservation of the remains. Over time, decomposed organic matter mixes with the parent material to produce the A-horizon which is often, as at Leaning Rock, thickned as a result. At Leaning Rock a midden area approximately $12 \mathrm{~m}$ in diamerer (see Figure 1) is loosely defined by dark soils and artifact concentrations; a second possible midden is about $10 \mathrm{~m}$ to the northwest. Excavations in this first area confirm that there are midden deposits up to $40 \mathrm{~cm}$ in depth. This is also the area where a hearth (Feature 1) and other features were identified below the midden zone. Though investigations were limited at Leaning Rock, one possible scenario is that the midden was the location of a 
house, probably the original structure during an initial Caddo occupation, that burned and then the area was used as a trash dump. There is evidence, although scant, to support this idea: (a) the presence of fired mud dauber nests (commonly found in structures); (b) quantities of charcoal and charcoal-stained soils; and (c) fire-altered (cracked) stone tools that fit together, suggesting they were burned in place.

Most of the excavations at Leaning Rock were concentrated around and in the $12 \mathrm{~m}$ diameter midden area, but there is evidence that there may be additional midden or habitation areas at the site. Located at the western boundary of the collection area is one such midden or habitation area, also approximately $12 \mathrm{~m}$ in diameter, marked by higher surface artifact densities and dark brown soil (see Figure 1). Shovel test 2 was located in that area (although not in it), and the finds there noted a possible midden deposit with dark brown soil to $30 \mathrm{~cm}$ bs; from $20-40 \mathrm{~cm}$ bs were eight sherds, eight charred nutshells, and one animal bone fragment.

The Feature 1 hearth was exposed in portions of Units 5-8 (Figure 9 and Table 2). It was first identified at 14 $\mathrm{cm}$ bs as a compact gray (10YR5/1) ash deposit. There was no evidence that the hearth was prepared or claylined. The ash deposits were collected for flotation and fine-screen processing. The ash contained mainly very small bone fragments, too small to be of any use in identifying animal species. The bone would be what would be expected from emptying cooking pots in the hearth. Perhaps the Leaning Rock folks sieved the ash, as they cleaned the hearth periodically, for bone fragments to add as temper to their pottery.

Underneath the ash deposits was a $4-5 \mathrm{~cm}$ thick layer of oxidized strong brown soil (7.5YR5/8). There was no evidence of a post underneath the hearth as have been found in some Caddo house construction. The soil directly underneath the hearth, $31 \mathrm{~cm}$ bs and below, was a yellowish-brown (10YR5/4) sandy loam and represents the original E-horizon. The original A-horizon was probably obliterated by the hearth and subsequent cleanings.

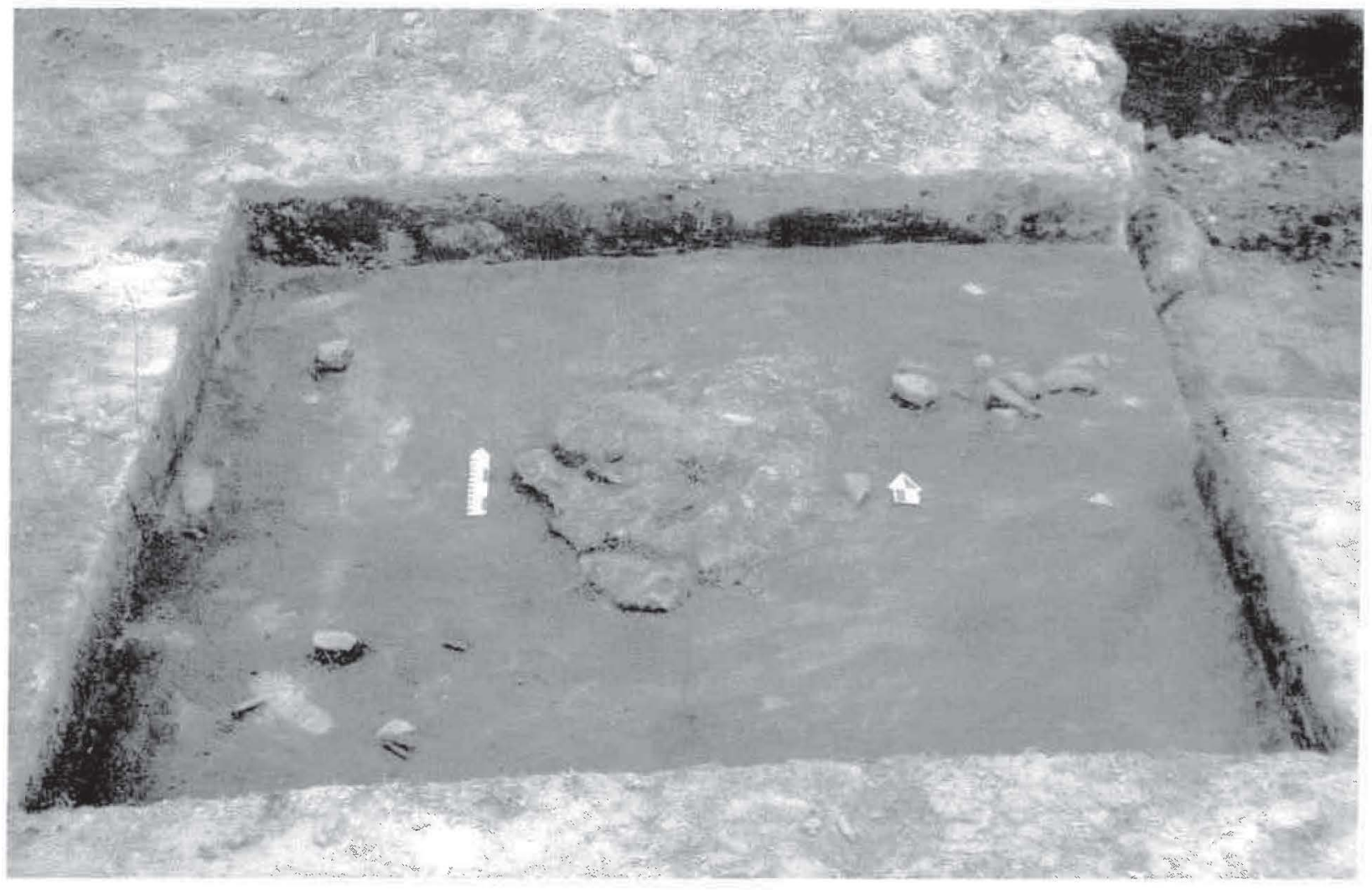

Figure 9. Feature 1 hearth. 
Table 2. Leaning Rock Features.

\begin{tabular}{|c|c|c|c|c|}
\hline Feature & Provenience & $\begin{array}{l}\text { Dimensions } \\
(\mathrm{cm})\end{array}$ & $\begin{array}{l}\text { Approx. Total } \\
\text { Feature Volume } \\
\text { (liters) }\end{array}$ & $\begin{array}{l}\text { Total } \\
\text { Depth }\end{array}$ \\
\hline Feature 1 & N104/E89 & $\begin{array}{l}88 \mathrm{~N} / \mathrm{S} \\
58 \mathrm{E} / \mathrm{W}\end{array}$ & 86.8 & $14-31 \mathrm{~cm} \mathrm{bs}$ \\
\hline Feature 2 & N103/E88 & $\begin{array}{l}65 \mathrm{~N} / \mathrm{S} \\
65 \mathrm{E} / \mathrm{W}\end{array}$ & 93.0 & $22-44 \mathrm{~cm} \mathrm{bs}$ \\
\hline Feature 3 & N104/E92 & $\begin{array}{l}65 \text { E/W } \\
\text { Extends into } \\
\text { South wall }\end{array}$ & 160.5 & $50-88 \mathrm{~cm} \mathrm{bs}$ \\
\hline Feature 4 & $\mathrm{~N} 105.5 / \mathrm{E} 91.5$ & $30 \mathrm{~cm}$ in diameter & 27.0 & $50-70 \mathrm{~cm} \mathrm{bs}$ \\
\hline Feature 5 & N108/E89 & $150 \mathrm{~cm}$ in diameter & 1282.5 & $50-107 \mathrm{~cm} \mathrm{bs}$ \\
\hline Feature 6 & N104.5/E91 & $30 \mathrm{~cm}$ in diameter & 22.5 & $50-75 \mathrm{~cm} \mathrm{bs}$ \\
\hline
\end{tabular}

This zone, Zone III in the profile, was devoid of any cultural materials and indicates the hearth was part of the original Caddo occupation at Leaning Rock. Zone III-A soils on either side of the hearth at the same level were a brown (10YR5/4) sandy loam stained by organic residues leaching down from the overlying midden zone (Zone II). The compact ash deposit of the hearth probably protected the soils directly underneath it. The midden ranged in chroma from very dark brown (10YR2/2 to black (10YR2/1) (Figure 10).

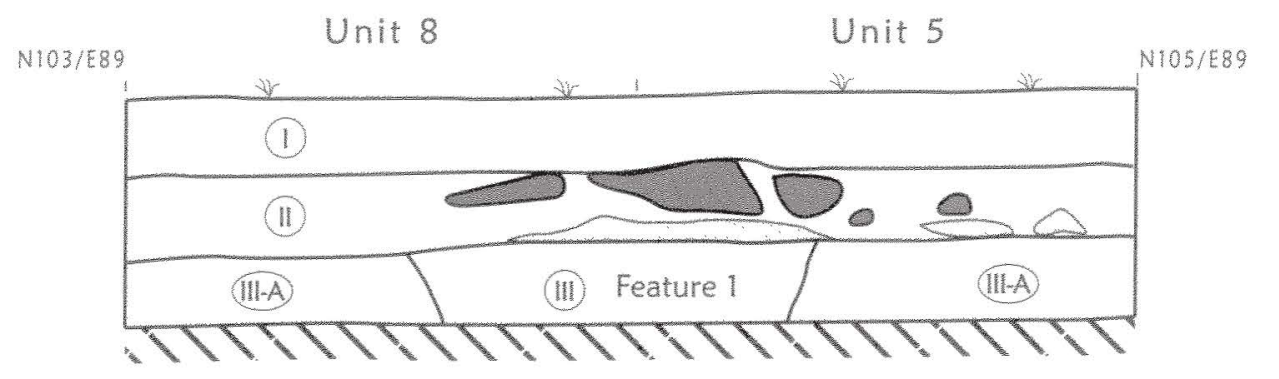

LEGEND

- Ash

Oxidized Soll

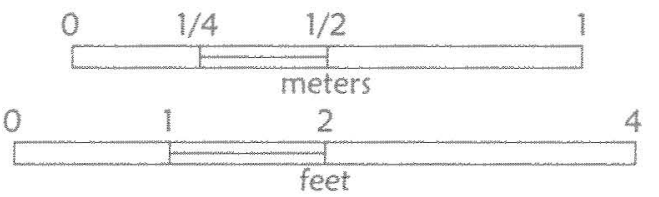

$56+40$

Figure 10. Profle of the Feature 1 hearth. 
The hearth at Leaning Rock was very similar to a hearth excavated at the Redwine site, which was not prepared nor had any post extending below it (Walters et al. 1998). Like at Leaning Rock. there were not enough excavations at Redwine to determine if the hearth there was located inside a structure but it was also surrounded by similar features (large and small pits and possible post holes). It is suspected that the hearths at both Leaning Rock and Redwine were indoor hearths, "used almost exclusively for warming, as suggested by white ash smoldering fires, which are less suitable for cooking than the higher-intensity outdoor fires with their constant flow of oxygen to fuel the flames" (Shafer 2003:37).

Alhough not usually associated with Caddo artifact assemblages, there was a large collection of fire-crackedrock (FCR) and ground stone tools (including several cup or nutting stones) in and around Feature 1 (Figure 11). Several of the ground stone tools had also been cracked as a result of thermal alteration. Some of the broken pieces of ground stone fit together, suggesting that they may have been on a house floor or occupation surface that burned.

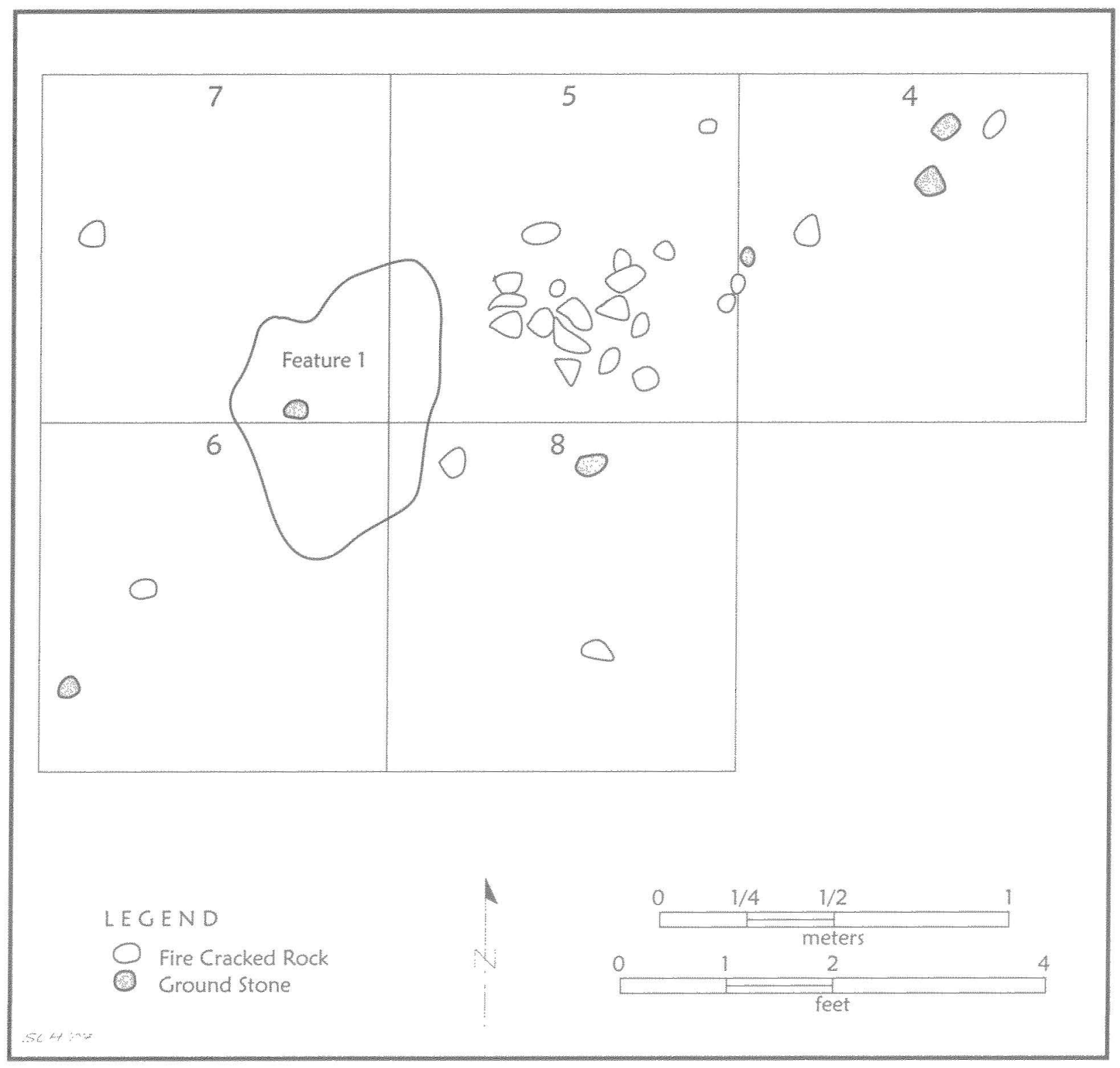

Figure 11. Plan view of Feature I hearth, ground stone tools, and FCR. 
Feature 2 was a circular pit that was identified at $22 \mathrm{~cm}$ bs in the northwest comer of Unit 9 . The fill was dark brown $(10 \mathrm{YR} 2 / 2)$ and contained a portion of a plain carinated bowl that extended from $24-36.5 \mathrm{~cm}$ bs. There was a FCR (128 g) at a bottom depth of $34 \mathrm{~cm}$ bs, and an unburned deer scapula at $37 \mathrm{~cm}$ bs. The deer scapula was buried quickly as it was not rodent chewed. The pit may have been a shallow depresssion dug in a house floor to cover up trash, or dug for another purpose, then filled with trash. The fill from Feature 2 was collected for fine screen and contained:

$\begin{array}{ll}\text { Decorated sherds } & 10 \\ \text { Plain sherds } & 20 \\ \text { Lithic debris } & 1 \\ \text { Mussel shell fragments } & 5 \\ \text { Bone fragments } & 211 \\ \text { Burned clay } & 1 \\ \text { Charred maize cobs } & 3 \\ \text { Charred nutshell } & 118 \\ \text { Charred wood fragments } & 170\end{array}$

Feature 3 was noted below the midden zone at $50 \mathrm{~cm}$ bs in Unit 1 and extended into the south wall (see Table 2). The feature was bisected at the south wall and fill was screened through $1 / 4$-inch hardware cloth. The top of the feature was not well defined as it blended with the overlying midden. There was a darker $(10 \mathrm{YR} 2 / 1)$ portion of the feature from $50-88 \mathrm{~cm}$ bs that contrasted with the remainder of the feature, which was very dark brown (10YR2/2) with charcoal and bone flecks. The surrounding soil was yellowish-brown (10YR5/4) sandy loam. Artifacts collected from Feature 3 include:

$\begin{array}{ll}\text { Decorated sherds } & 3 \\ \text { Plain body sherds } & 13 \\ \text { Lithic debris } & 1 \\ \text { Smoothing pebble } & 1 \\ \text { Bone fragments } & 18 \\ \text { Mussel shell } & 4 \\ \text { Charred nutshell } & 8 \\ \text { Charred wood fragments } & 7\end{array}$

One whole mussel shell (Tritogonia verrucosa) was submitted for radiocarbon dating from Feature 3 (Beta-218526).

Feature 4 was a dark yellowish-brown (10YR3/4) circular stain with bone and charcoal flecks that was noted at $50 \mathrm{~cm}$ bs in. Unit 11 (Figure 12). It extended to $70 \mathrm{~cm}$ bs and had a rounded bottom. The feature was bisected north-south and the east portion was dry screened through 1/4-inch hardware cloth to recover artifacts. Artifacts collected include one decorated sherd and seven plain body sherds.

Feature 5 was a large circular pit that was noted at $50 \mathrm{~cm}$ bs in Unit 12 and extended into the north and west walls (Figure 13), as well as beyond the unit (see Figure 7). Its fill was a dark yellowish-brown (10YR3/4) with flecks of charcoal. The feature had sloping sides and a flat bottom that extended into the red $(2.5 \mathrm{YR} 5 / 6)$ sandy clay subsoil (Figures 14-15). 


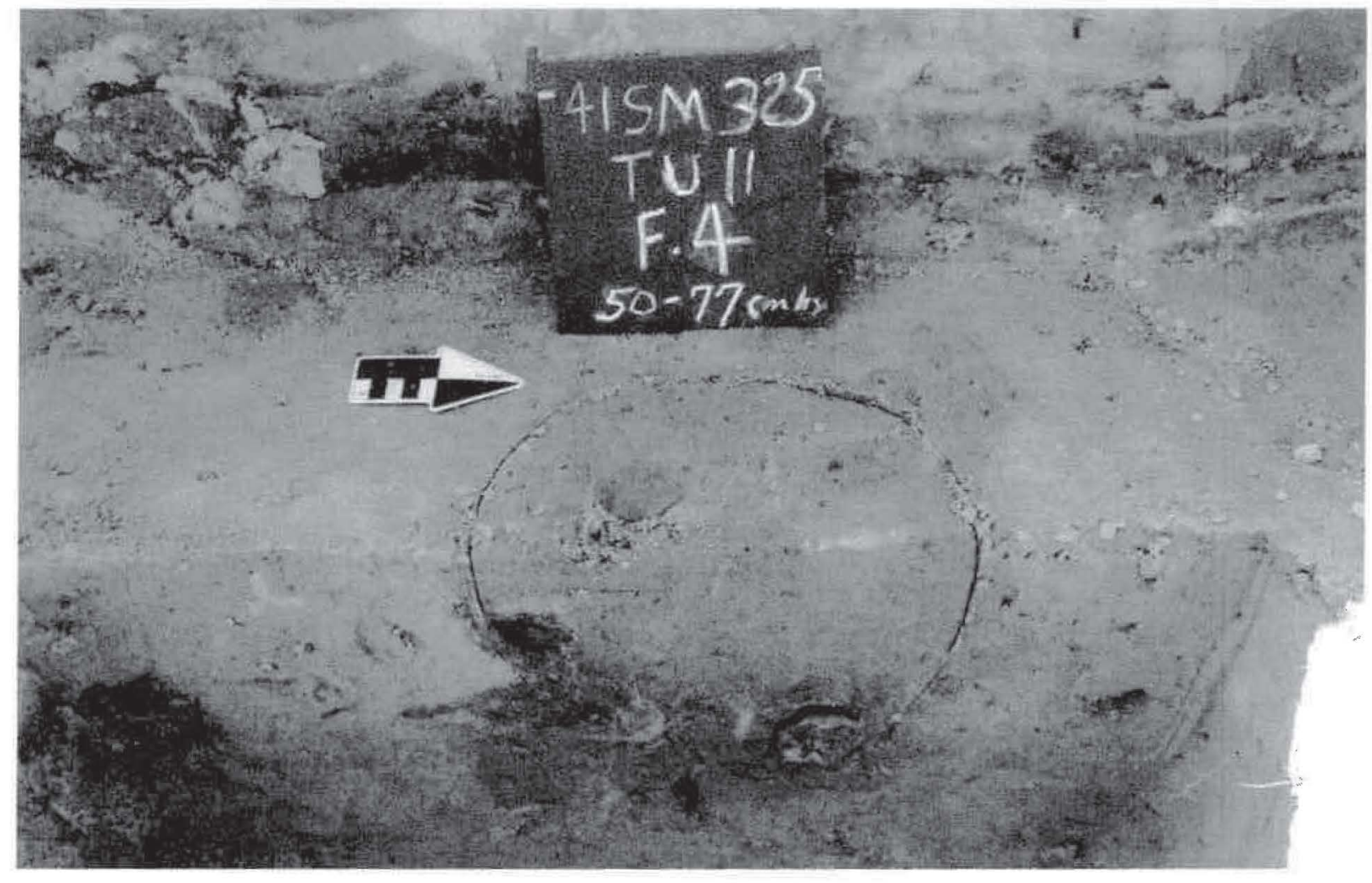

Figure 12. Photograph of Feature 4.

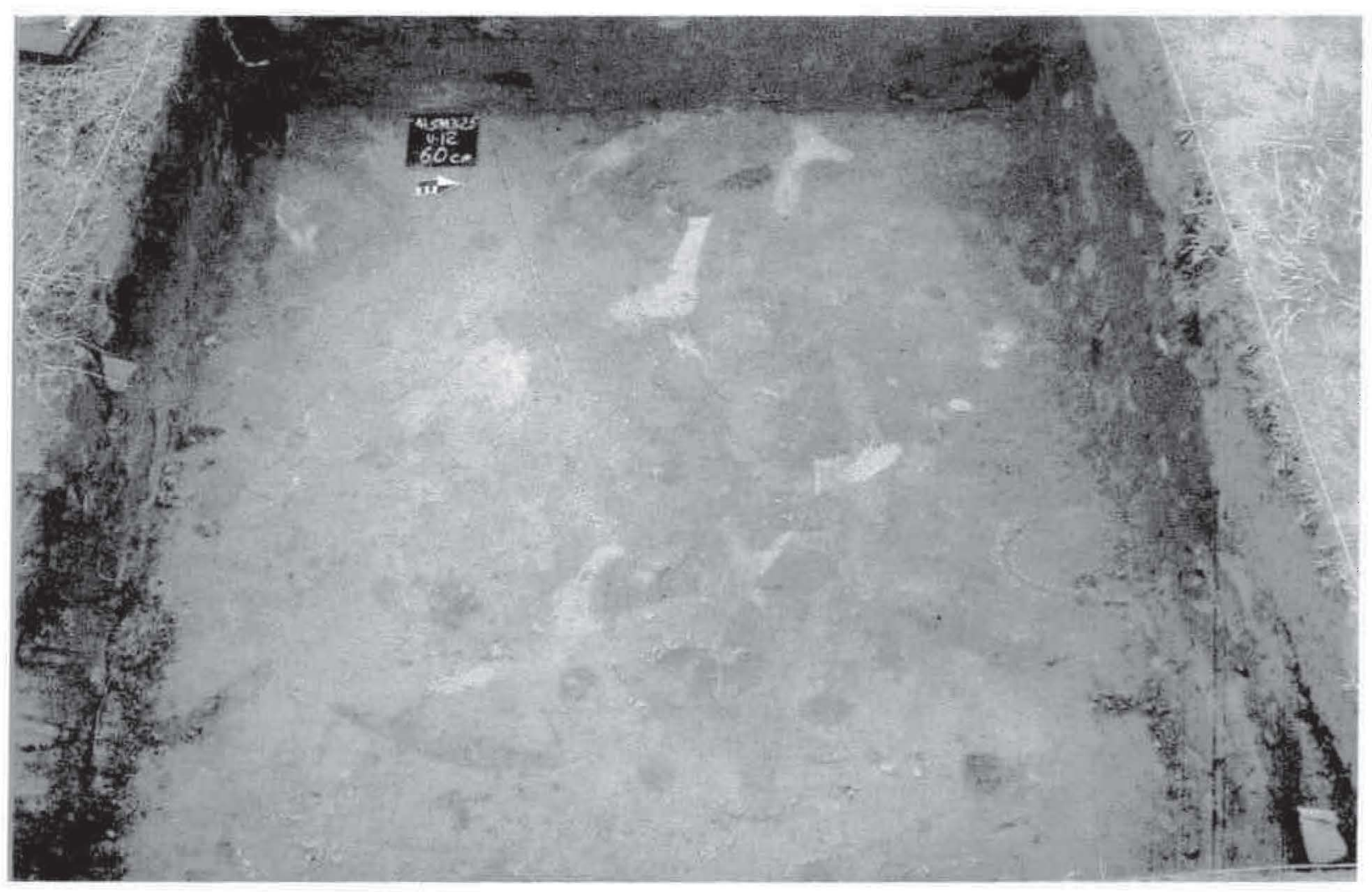

Figure 13. Photograph of Feature 5 at $60 \mathrm{~cm}$. 


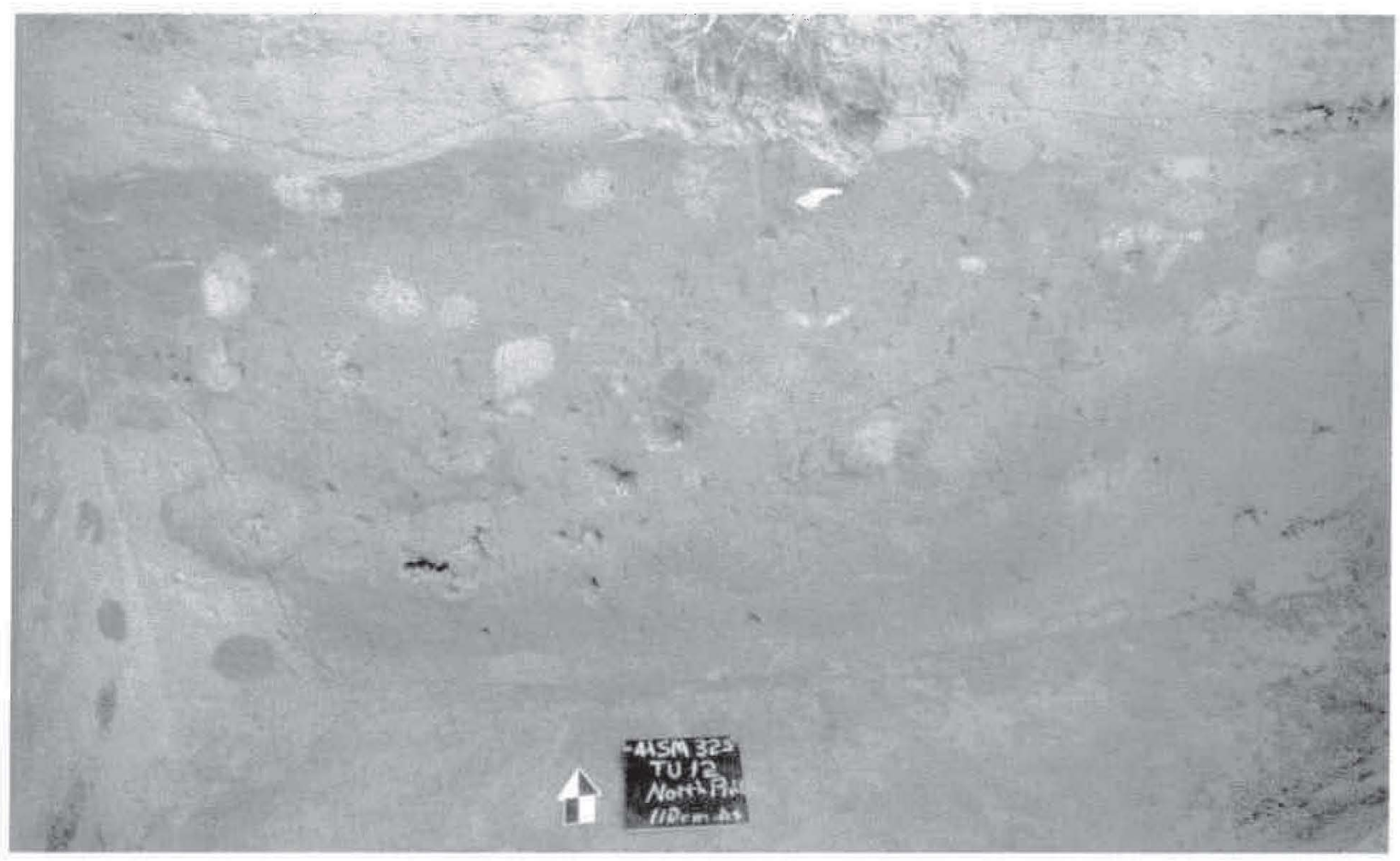

Figure 14. Feature 5 at $107 \mathrm{~cm}$ bs.

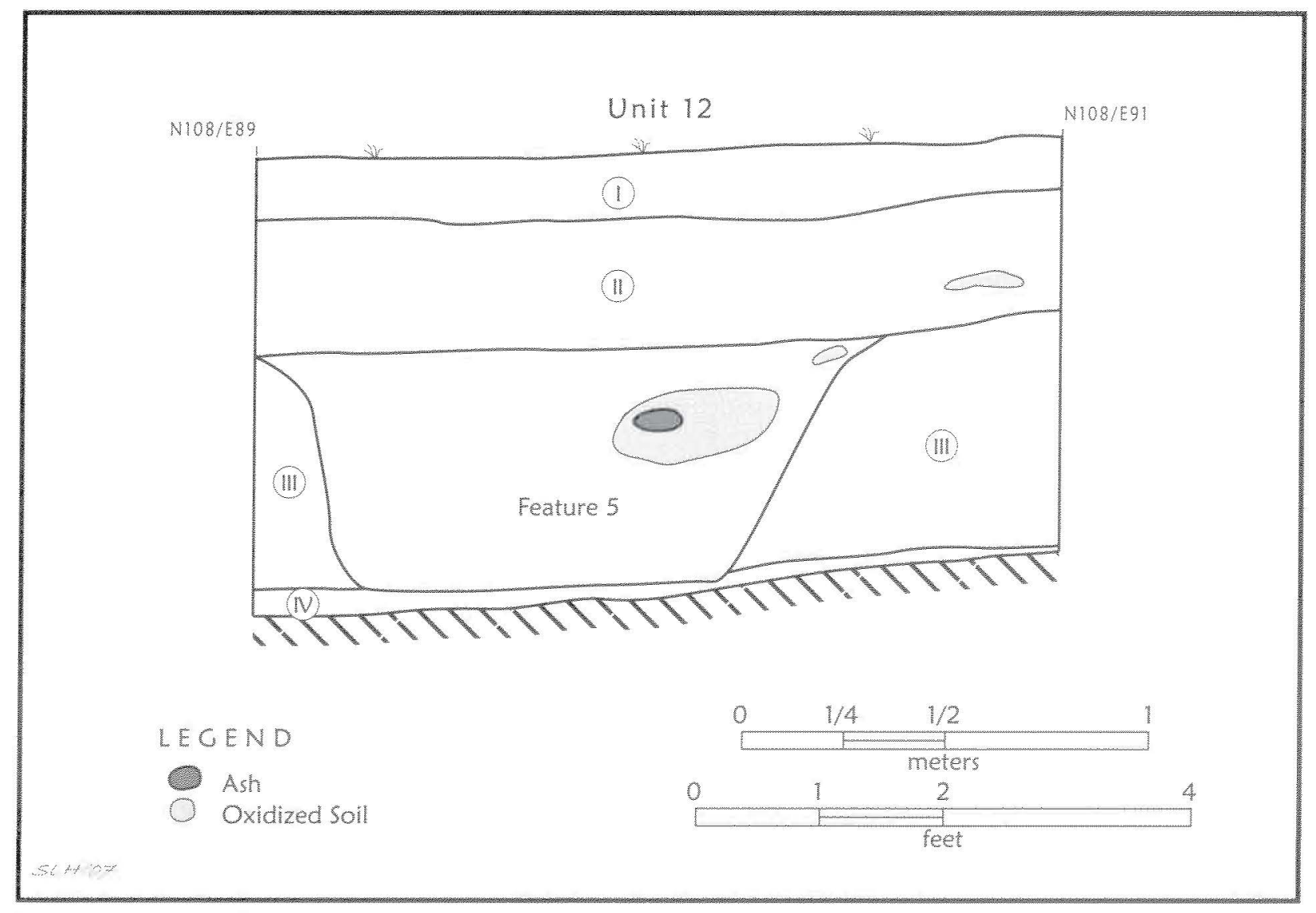

Figure 15. Profile of Feature 5. 
Artifacts recovered in Feature 5 include:

$\begin{array}{ll}\text { Decorated sherds } & 62 \\ \text { Plain body sherds } & 134 \\ \text { Lithic debris } & 11 \\ \text { Dart point } & 1 \\ \text { Mussel shell (including } 2 \text { whole) } & 141 \\ \text { Sandstone abraiders } & 2 \\ \text { Fire-cracked-rock } & 2(212.1 \mathrm{~g}) \\ \text { Bone fragments } & 830 \\ \text { Charred nutshell } & 320.5 \mathrm{~g} \\ \text { Charred wood fragments } & 37.4 \mathrm{~g}\end{array}$

A total of $11.4 \mathrm{~g}$ of nutshell from $50-60 \mathrm{~cm}$ bs was submitted to Beta Analytic for radiocarbon dating (Beta-218500).

Feature 6 was a dark brown (10YR3/3) circular stain that was noted at $50 \mathrm{~cm}$ bs between Unit 4 and Unit 11 . At $55 \mathrm{~cm}$ bs it had a diameter of $20 \mathrm{~cm}$. Feature 6 was bisected along a north-south profile and half of the fill was screened through 1/4-inch mesh. In profle, Feature 6 had straight sides with a rounded bottom at $75 \mathrm{~cm}$ bs, resembling a possible post hole for a wall post (Figure 16).

Only a few artifacts were recovered from Feature 6, among them one decorated sherd, three bone fragments, and three charred nutshells.

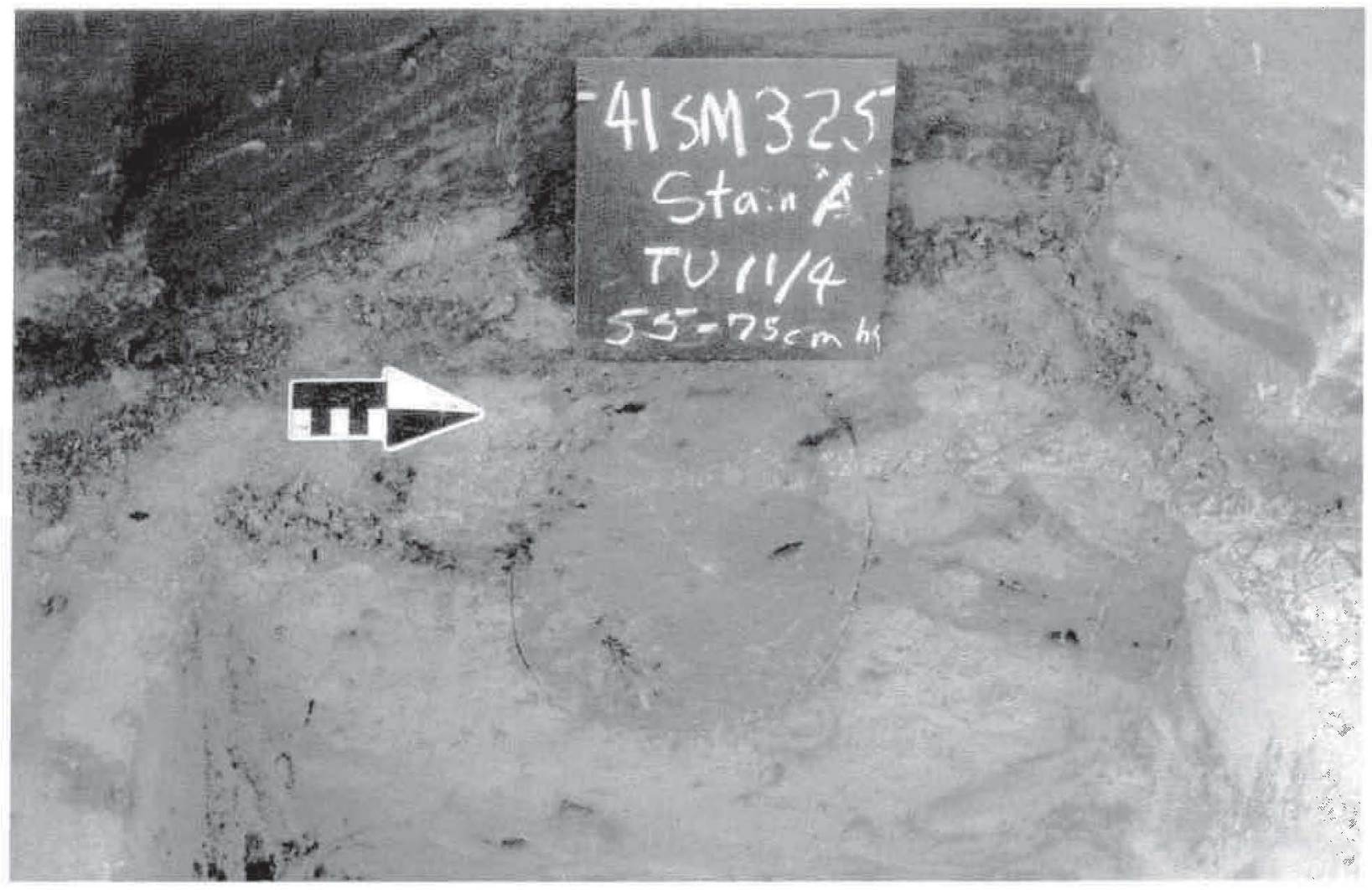

Figure 16. Feature 6 


\section{RADIOCARBON DATES FROM THE LEANING ROCK SITE}

There are six radiocarbon dates from Leaning Rock. All of the dates with one exception (see below) are in a fairly tight range at either 1 or 2 sigma. The average age of the calibrated radiocarbon date intercepts is cal AD 1349, with a range from $A D$ 1280-1420 (Tables 3-4).

Four dates are from charred Carva sp. nutshell from features and/or arbitrary levels in test units. One (Beta-210925) was an AMS date on a charred maize cob from Unit 3.

Another radiocarbon date (Beta-218526) was from a large intact mussel shell from Feature 3 (see Table 3). Due to a reservoir effect, the date is some 200-300 years too old. The reservoir effect is a process whereby "old carbon" is recycled and incorporated into shellfish, inflating their actual age is some cases by several hundred years (Culleton 2006). Unfortunately, there are no regional reservoir correction rates developed for this area, so the date has to be discounted as being of any value in dating prehistoric cultural activities at Leaning Rock. There is the beginning of a correction rate, however, because we have radiocarbon dates on mussel shell and charred nutshells from several other sites in East Texas. At the Kah-hah-ko-wha site (41CE354), for instance, the mussel shell dates are 300-350 years too old (Perttula and Nelson 2007:63), while mussel shell dates from the Buddy Hancock site (41SY45) are 340-480 years too old. At the Robert Griffin site (4ISY41), a mussel shell date is more than 600 years older than the Caddo archeological deposits from which it came.

Table 3. Radiocarbon Dates from the Leaning Rock Site.

\begin{tabular}{|c|c|c|c|}
\hline Beta & Provenience & $\begin{array}{l}1 \text { sigma cal } \\
\text { (A.D.) age range }\end{array}$ & $\begin{array}{l}2 \text { sigma cal } \\
\text { (A.D.) age range }\end{array}$ \\
\hline Beta 204576 & $\begin{array}{l}\text { Unit } 1 \\
30-40 \mathrm{~cm} \text { bs }\end{array}$ & $\begin{array}{l}\text { Cal AD } 1260-1300 \\
\text { Cal AD } 1350-1390\end{array}$ & Cal AD $1200-1320$ \\
\hline Beta-204577 & $\begin{array}{l}\text { Unit } 3 \\
30-40 \mathrm{~cm} \text { bs }\end{array}$ & Cal AD $1290-1400$ & Cal AD $1270-1420$ \\
\hline Beta-210925* & $\begin{array}{l}\text { Unit } 3 \\
30-40 \mathrm{~cm} \text { bs }\end{array}$ & Cal AD $1410-1440$ & Cal AD $1400-1450$ \\
\hline Beta-218500 & $\begin{array}{l}\text { Feature } 5 \\
50-60 \mathrm{~cm} \text { bs }\end{array}$ & $\begin{array}{l}\text { Cal AD } 1320-1350 \\
\text { Cal AD } 1390-1420\end{array}$ & Cal AD $1300-1430$ \\
\hline Beta-218526\# & $\begin{array}{l}\text { Feature } 3 \\
50-60 \mathrm{~cm} \text { bs }\end{array}$ & Cal AD 1010-1180 & Cal AD 980-1240 \\
\hline Beta-224873 & $\begin{array}{l}\text { Feature } 2 \\
30-44 \mathrm{~cm} \text { bs }\end{array}$ & Cal AD 1260-1290 & $\begin{array}{l}\text { Cal AD } 1210-1320 \\
\text { Cal AD } 1350-1390\end{array}$ \\
\hline $\begin{array}{l}\text { *AMS date on } \\
\text { \# Mussel shell }\end{array}$ & $\begin{array}{l}\text { ecob } \\
1.1996)\end{array}$ & & \\
\hline
\end{tabular}


Table 4. Calbrated radiocarbon date intercepts.

\begin{tabular}{|c|c|}
\hline Beta & $\begin{array}{l}\text { Intercept of radiocarbon age } \\
\text { with calibration curve }\end{array}$ \\
\hline 204576 & Cal AD 1280 (Cal BP 670) \\
\hline 204577 & $\begin{array}{l}\text { Cal AD } 1310(\mathrm{Cal} \mathrm{BP} 640) \text { and } \\
\text { Cal AD } 1370(\mathrm{Cal} B \mathrm{P} 580) \text { and } \\
\text { Cal AD } 1380(\mathrm{Cal} B P 570)\end{array}$ \\
\hline $210925^{*}$ & Cal AD 1420 (Cal BP 530) \\
\hline 218500 & Cal AD 1400 (Cal BP 550) \\
\hline $218526^{* * *}$ & Cal AD 1040 (Cal BP 910) \\
\hline 224873 & Cal AD 1280 (Cal BP 670) \\
\hline \multicolumn{2}{|c|}{$\begin{array}{l}\text { Maize, } 13 \mathrm{C} / 12 \mathrm{C} \text { Ratio is }-10.1 \% \\
* \text { Mussel shell, } 13 \mathrm{C} / 12 \mathrm{C} \text { Ratio is }-13.1 \% \\
\text { Charred nutshell } 13 \mathrm{C} / 12 \mathrm{C} \text { ratios range from }-25.0 \% \text { to }-25.6 \%\end{array}$} \\
\hline
\end{tabular}

Provisionally, then, a correction rate of $300-480$ years may be a reasonable first approximation of the years that would need to be added to anomalously old mussel shell dates from East Texas Caddo sites to arrive at an accurate absolute age.

\section{LEANING ROCKARTIFACTS}

Not including charred plant remains and animal bones (both burned and unburned), a total of 3486 artifacts have been recovered from the Leaning Rock site in the present investigations (Table 5). Plain and decorated sherds comprise more than 91 percent of all the recovered artifacts, with various lithic artifacts accounting for another 8 percent of the total. There are only trace amounts of ceramic pipe sherds, fired clay/daub, or mud dauber nests in the artifact assemblage.

The rarity of chipped stone tools - especially arrow points - and lithic debris is particularly notable at the Leaning Rock site. It seems clear that not much tool manufacture or hunting (at least using chipped stone tools) took place here during the 14 th century Caddo occupation. 
Table 5. Summary of the Prehistoric Artifacts recovered from the Leaning Rock site.

\begin{tabular}{|lcc|}
\hline Artifact Class & No. & Percent of Assemblage \\
\hline Dart points & 7 & 0.2 \\
Arrow points and preforms & 5 & 0.1 \\
Chipped stone tools & 16 & 0.5 \\
Ground stone tools & 28 & 0.8 \\
Lithic debitage & 165 & 4.8 \\
Fire-cracked rock & 67 & 1.9 \\
& 693 & 19.8 \\
Decorated Sherds & $2490 *$ & 71.4 \\
Plain Sherds & 1 & Trace \\
Pipe sherds & 4 & 0.1 \\
Mud dauber nest & 10 & 0.3 \\
Fired clay/daub & 3486 & 100.0 \\
\hline Totals & \\
\hline * including six spindle whorl sherds & \\
\hline
\end{tabular}

\section{SUMMARY OF THE LEANING ROCK SITE (41SM325) LITHICS}

\section{Harry J. Shafer}

Shafer (2007) provides a detailed analysis of the chipped and ground stone lithic artifacts recovered from the excavations at the Leaning Rock site. I summarize those findings here (see also Table 5).

First, the lithic sample from the Leaning Rock site indicates a multi-component occupation. Diagnostic point types were Big Sandy, Gary, Perdiz-Bassett, and Friley. The most prominent components are a Woodland assemblage identified by Gary dart points and a Middle Caddo assemblage marked by arrow point types Perdiz Bassett. A single Friley point may hint of a very brief Early Caddo presence at the site as well. The small sample of projectile points provides some limited stylistic information that is substantiated at other Middle Caddo sites (Rogers and Perttula 2004:167-174). The small sample of dart points also indicates the site was probably a shortterm encampment for a small Late Archaic or Woodland group. The sample is dominated by Gary points; this point type can be found on virtually every hill or knoll in proximity to water throughout East Texas. The bow and arrow replacement of the atlat spear probably took place during the Middle-Late Woodland transition at ca. AD 600-800, and may have defined a Late Woodland phase along with changes in ceramic styles (Perttula 2004a:376). 
The Big Sandy point would suggest either a thin Early Archaic component (predating ca. 8000 years ago) was represented at Leaning Rock, or the artifact was picked up and introduced in the site by the Caddo or Late Archaic-Early Woodland groups. Collecting from earlier sites was not uncommon among the Caddo (Shafer 1973:181-187). The admixture of dart points and arrow points at the Leaning Rock site deposits is attributed to mixing due to the nature of the relatively shallow and bioturbated deposits.

Weapons for hunting and warfare were obviously maintained by all occupants of the Leaning Rock site as indicated by the presence of projectile points. Woodworking implements are well represented by bipolar wedges or battered pieces, a small makeshift adze or celt, and celt fragments. Utilized flakes were surprisingly rare, and their rarity may be attributed to the paucity of suitable raw material, and to the historically known fact that the Caddo used the sharp edges of highly silicate native cane as knives.

Pot polishing stone were also found at the site. These highly polished and striated pebbles were the products of polishing or burnishing the surfaces of leather-hard ceramics. Their presence in the sample stands as circumstantial evidence that some of the ceramics at the site were locally produced. These tools do not provide useful chronological information because they are associated with ceramic technology, and may occur with any ceramic component.

Finally, the lithic artifact sample from the Leaning Rock site provides some possibly significant, if not vague, hints of resource utilization through time. The resource utilization probably relates to relative degrees of mobility or sedentary lifestyles. For example, the single Big Sandy point is a high quality chert, probably of Edwards formation origin (Banks 1990:59 62). The Big Sandy is an Early Archaic point style associated with groups who practiced highly mobile lifestyles. The Gary points, arrow points, and debitage, on the other hand, are of materials regarded here as locally available in Northeast Texas, including orthoquarzites, small chert pebbles, and silicified wood. Gary points are regarded as being associated with Woodland period occupations; Woodland grouns were probably seasonally mobile, with more restricted mobility compared to the Early Archaic groups. Caddo groups were probably even more restricted in their movements compared to the Woodland groups. With trends toward reduced mobility through time, we might expect more intensive uses of local as opposed to non-local resources, and the importation of non-local resources occurring mostly in the form of finished items (see Shafer 1973:337-364).

\section{GROUND STONE TOOLS}

Numerous hematite (ferruginous sandstone) ground stone tools were recovered at Leaning Rock (Figure $17 \mathrm{a}-\mathrm{c}$ and Table 6), beyond the polishing stones and celts

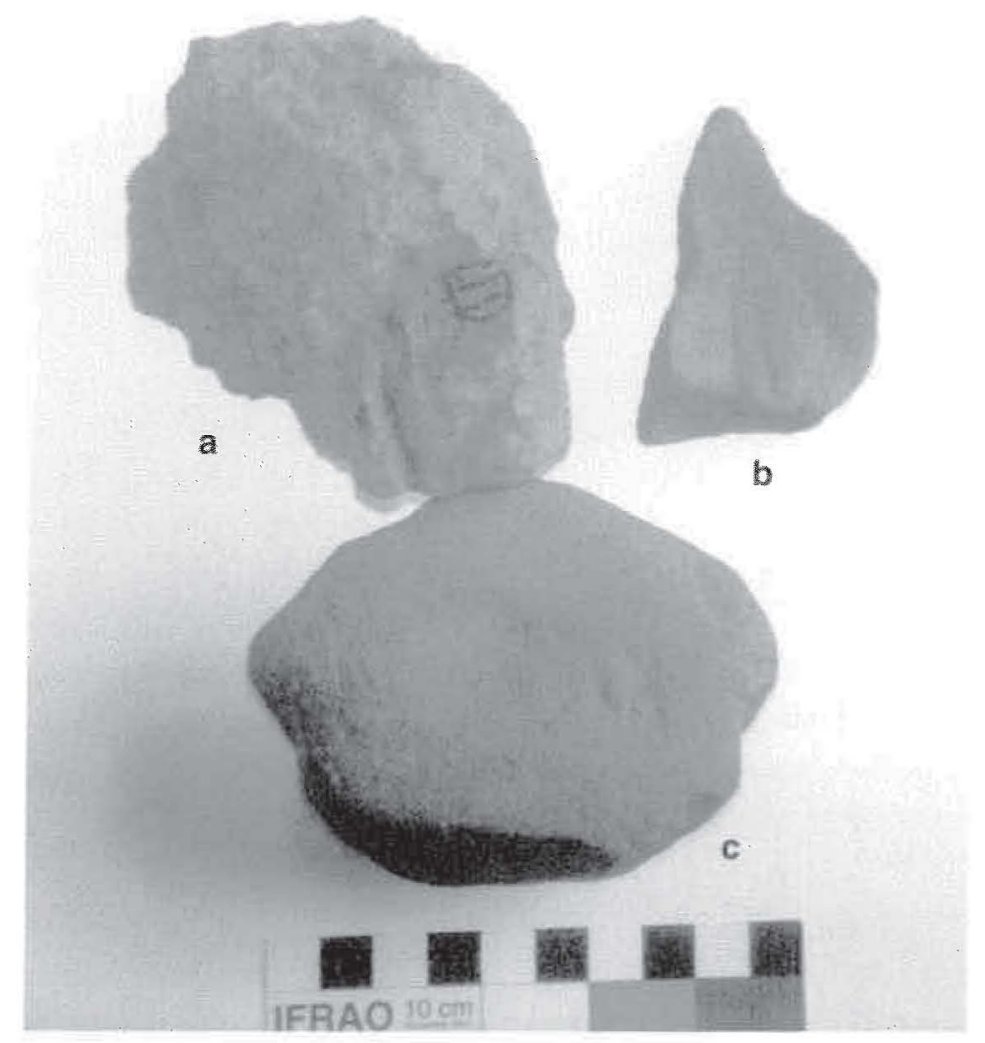

Figure 17. Nutting stone and abraders: $a-b$, abraders; $c$, nutting stone. 
Table 6. Leaning Rock Ground Stone Tools.

\begin{tabular}{|c|c|c|c|}
\hline Location & $\begin{array}{c}\text { Bottom } \\
\text { Depth }(\mathrm{cm})\end{array}$ & $\begin{array}{l}\text { Weight } \\
(\mathrm{g})\end{array}$ & Comments \\
\hline U.1 & 45 & 266.5 & $\begin{array}{l}\text { Nutting stone, } 8.5 \times 6 \times 4 \mathrm{~cm}, 3.5 \mathrm{~cm} \text { diameter } \\
\text { depression on one side }\end{array}$ \\
\hline U.2 & $0-10$ & 67.8 & Mano frag., $5.5 \times 3 \times 3 \mathrm{~cm}$. smooth one side \\
\hline U.3 & $10-20$ & 46.2 & Metate frag., $5.5 \times 3.5 \times 1 \mathrm{~cm}$, smooth one side \\
\hline 0.3 & $10-20$ & 60.6 & $\begin{array}{l}\text { Metate frag., } 4.5 \times 3.5 \times 1.5 \mathrm{~cm} \text {, smooth on } \\
\text { one side }\end{array}$ \\
\hline U.3 & 26 & 490.0 & $\begin{array}{l}\text { Nutting stone, } 10 \times 7 \times 4 \mathrm{~cm} \text {, smooth one } \\
\text { side with } 3 \mathrm{~cm} \text { diameter depression }\end{array}$ \\
\hline U.3 & 46 & 775.0 & Metate, $14 \times 9 \times 5 \mathrm{~cm}$, smooth one side \\
\hline U.4 & $10-20$ & 34.4 & Metate frag. $5 \times 2.5 \times 1.5 \mathrm{~cm}$, smoothed one side \\
\hline 0.4 & 28 & 109.5 & Mano frag., $4 \times 3 \times 4 \mathrm{~cm}$, smooth 2 sides \\
\hline U.4 & 29 & 383.2 & Abrader, parallel linear deep grooves \\
\hline U.4 & 27 & 73.8 & Abrader, three $0.3 \mathrm{~cm}$ wide grooves \\
\hline U.5 & 26 & 490.0 & $\begin{array}{l}\text { Nutting stone, } 10 \times 7 \times 4 \mathrm{~cm} \text {, smooth one } \\
\text { side with concave } 3 \times 3 \mathrm{~cm} \text { circular depression }\end{array}$ \\
\hline 0.6 & $20-30$ & 227.2 & Metate frag., $10 \times 5 \times 3 \mathrm{~cm}$, smooth one side \\
\hline U.6 & 33 & 420.0 & Mano, $7 \times 7 \times 3 \mathrm{~cm}$, smooth one side \\
\hline U.8 & 24 & 93.1 & Metate frag., $6 \times 4 \times 3 \mathrm{~cm}$, smooth one side \\
\hline U.7 & 18 & 38.9 & Metate frag.. $5 \times 4 \times 1.5 \mathrm{~cm}$, smooth one side \\
\hline 0.9 & $20-30$ & 24.6 & Mano (?) frag., $6 \times 2 \times 1.5 \mathrm{~cm}$, smooth one side \\
\hline U.11 & $10-20$ & 61.7 & Metate frag, $5 \times 4.5 \times 1.5 \mathrm{~cm}$, smooth two sides \\
\hline U.11 & $20-30$ & 35.8 & Metate spall, $6 \times 6 \times 1 \mathrm{~cm}$, smooth one side \\
\hline 0.12 & $60-70$ & 266.5 & $\begin{array}{l}\text { Abrader, } 13 \times 10 \times 4 \mathrm{~cm} \text {, four linear } 4 \mathrm{~mm} \\
\text { wide grooves }\end{array}$ \\
\hline U.12 & 75 & 590.0 & $\begin{array}{l}\text { Abrader, } 9 \times 6 \times 2 \mathrm{~cm} \text {, six v-shaped linear } \\
\text { grooves on one side, one opposing side }\end{array}$ \\
\hline
\end{tabular}

discussed by Shafer (2007). Containing rounded or angular quartz grains of various sizes, this native material was well suited for food processing; tool manufacture and maintence; and all-around grinding/smoothing activities. It was also readily available in exposed beds nearby as cobbles or tabular slabs.

The 20 ground stone tools listed in Table 6 include nine metates or metate fragments, four manos, four abraders, and three nutting stones. Plant grinding and crushing/pulverizing activities were obviously important tasks during the 14 th century Caddo occupation at the Leaning Rock site. 


\section{FIRE-CRACKED AND HEATED ROCK}

There were 65 ferruginous sandstone fire-cracked rock (FCR) with a total weight of $11.47 \mathrm{~kg}$ collected from excavations at Leaning Rock (Table 7). Most of these FCR came from the midden zone and were in association with other Caddo artifacts. In the discussion of Feature 1 it was noted that there were several FCR surrounding the hearth. One was a large unmodified sandstone $(30 \times 25 \times 15 \mathrm{~cm}$ ) "kitchen rock" (weighing $15.4 \mathrm{~kg}$ ) that was severely altered by exposure to heat. It probably served as a working platform to roast objects or hold vessels.

Table 7. Fire-cracked and heated rocks.

\begin{tabular}{|c|c|c|}
\hline Provenience & $\begin{array}{l}\text { Bottom } \\
\text { depth }(\mathrm{cm})\end{array}$ & Weight (g or $\mathrm{kg}$ ) \\
\hline U.1/3 & 45 & $15.4 \mathrm{~kg}^{*}$ \\
\hline U.1 & $30-40$ & $71.9 \mathrm{~g}$ \\
\hline U.4 & 37 & $158.5 \mathrm{~g}$ \\
\hline U. 4 & 26 & $85.2 \mathrm{~g}$ \\
\hline U.4 & 26 & $53,4 \mathrm{~g}$ \\
\hline U.4 & 32 & $400.0 \mathrm{~g}$ \\
\hline U.4 & 26 & $88.4 \mathrm{~g}$ \\
\hline U.5 & 24 & $88.2 \mathrm{~g}$ \\
\hline U.5 & 26 & $88.2 \mathrm{z}$ \\
\hline U.5 & 29 & $86.9 \mathrm{~g}$ \\
\hline U.5 & 20 & $490.0 \mathrm{~g}$ \\
\hline 0.5 & 22 & $259.5 \mathrm{~g}$ \\
\hline U.5 & 22 & $109.5 \mathrm{~g}$ \\
\hline 0.5 & 22 & $550.0 \mathrm{~g}$ \\
\hline U.5 & 24 & $258.9 \mathrm{~g}$ \\
\hline U.S & 26 & $257.2 \mathrm{~g}$ \\
\hline U.5 & 22 & $150.0 \mathrm{~g}$ \\
\hline U.5 & 13 & $127.5 \mathrm{~g}$ \\
\hline U.5 & 22 & $177.3 \mathrm{~g}$ \\
\hline U.5 & 22 & $266.3 \mathrm{~g}$ \\
\hline U.5 & 23 & $140.0 \mathrm{~g}$ \\
\hline U.5 & 24 & $380.0 \mathrm{~g}$ \\
\hline U.6 & 30 & $75.4 \mathrm{~g}$ \\
\hline U.6 & 33 & $70.8 \mathrm{~g}$ \\
\hline U.7 & 19 & $103.1 \mathrm{~g}$ \\
\hline 0.7 & $24 / 26$ & $159.1 \mathrm{~g}(2)$ \\
\hline U.8 & 23 & $180.8 \mathrm{~g}$ \\
\hline U.8 & 0.10 & $43.6 \mathrm{~g}(2)$ \\
\hline U.8 & $10-20$ & $16.5 \mathrm{~g}$ \\
\hline 09 & $20-30$ & $45.3 \mathrm{~g}$ \\
\hline U.9 & $30-40$ & $42.3 \mathrm{~g}(2)$ \\
\hline U.9 & Fea. 2 & $128.0 \mathrm{~g}$ \\
\hline 0.10 & $10-20$ & $81.2 \mathrm{~g}$ \\
\hline$U, 10$ & $20-30$ & $83.6 \mathrm{~g}$ \\
\hline
\end{tabular}


Table 7. (Contimued)

\begin{tabular}{|ccc|}
\hline Provenience & $\begin{array}{c}\text { Bottom } \\
\text { depth }(\mathrm{cm})\end{array}$ & Weight $(\mathrm{g}$ or kg) $(\mathrm{N})$ \\
\hline U.11 & $20-30$ & $3.05 \mathrm{~kg}(11)$ \\
U.11 & $30-40$ & $661.5 \mathrm{~g}(2)$ \\
U.12 & $20-30$ & $107.0 \mathrm{~g}(4)$ \\
U.12 & $40-50$ & $205.4 \mathrm{~g}(2)$ \\
$\mathrm{U} 12$ & $70-80$ & $212.1 \mathrm{~g}(2)$ \\
\hline .13 & $30-40$ & $1.9 \mathrm{~kg}(8)$ \\
\hline
\end{tabular}

FCR are usually associated with indirect heating, which is one technology (and an old one in the Caddo area of East Texas) in the science of preparing food. Rocks would have been heated and then added to containers containing water and plant and animal matter. As a result of thermal altering during the heating/cooking prom cess, the heated rocks often crack and after reaching too small a size to be practical are discarded. It is usually assumed that with the increased usage of ceramics there would be a decrease in use of indirect heating, but clearly this technology was still being practiced by the Caddo at Leaning Rock.

\section{THE DECORATED CADDO VESSEL SHERDS AND PLAIN VESSEL RIMS FROM THE LEANING ROCK SITE (4ISM325), SMITH COUNTY, TEXAS}

\section{Timothy K. Perttula}

\section{INTRODUCTION}

A total of 693 decorated ceramic vessel sherds and a single decorated pipe sherd comprise the collection of decorated sherds from the archeological excavations at the Leaning Rock site. This prehistoric Caddo site was occupied during the 14 th century A.D. The mean average of five calibrated radiocarbon dates, at 2 sigma, is AD 1297-1389. The mean intercept of the calibrated dates is AD 1349. The plain: decorated sherd ratio is 3.59. The total assemblage of all sherds numbers 3183 (see Table 5).

The analysis of these decorated sherds follows the methods and procedures defined by Perttula and Nelson (2003:85-86) and in numerous other ceramic vessel sherd analyses of East Texas Caddo sites. I focus on differences in the sherds in paste and temper; type of sherd (rim, body, and base); rim and lip form; decoration (i.e.. techniques, elements, and motifs); surface treatment; and oxidation patterns/firing conditions.

\section{HORIZONTAL AND VERTICAL CHARACTER OF THE SAMPLE OF DECORATED SHERDS}

The 693 decorated sherds are from the following contexts at Leaning Rock: shovel tests $(n=8)$, surface collection $(n=101), 1 \times 1,1 \times 2$, and $2 \times 2$ m excavation units $(n=527)$, and features within those units ( $n=57)$. Table 8 lists the number of decorated sherds by unit and by feature. 
Table 8. Number of decorated sherds from the Leaning Rock site (4ISM325),

\begin{tabular}{|c|c|c|c|}
\hline Unit & $\begin{array}{l}\text { No of decorated } \\
\text { sherds }\end{array}$ & Feature No. & $\begin{array}{c}\text { No. of decorated } \\
\text { sherds }\end{array}$ \\
\hline 1 & 42 & 2 & 5 \\
\hline 2 & 22 & 3 & 2 \\
\hline 3 & 26 & 4 & 1 \\
\hline 4 & 40 & 5 & 48 \\
\hline 5 & 10 & 6 & 1 \\
\hline 6 & 17 & & \\
\hline 7 & 17 & & \\
\hline 8 & 21 & & \\
\hline 9 & 70 & & \\
\hline 10 & 74 & & \\
\hline$\|$ & 69 & & \\
\hline 12 & 72 & & \\
\hline 13 & 47 & & \\
\hline
\end{tabular}

By depth, in the excavation units, almost $80 \%$ of the decorated sherds are from $10-40 \mathrm{~cm}$ bs, with another $13 \%$ from $0-10 \mathrm{~cm}$ bs. The remainder of the decorated sherds were recovered from $40-60 \mathrm{~cm}$ bs. The density of decorated sherds is 21.8 sherds per $\mathrm{m}^{2}$. By volume, the density is 48.5 sherds per $\mathrm{m}^{3}$.

From surface contexts, the decorated sherds are found over a ca. 40 (north-south) $\mathrm{x} 45$ (east-west) $\mathrm{m}$ area ( 1800 $\mathrm{m}^{2}$ or $0.45 \mathrm{acres}$ ) of the surface collection grid (Figure 18). Based on the high densities of decorated sherds from the N85 to N90 grid units, it is clear that the distribution of the Caddo decorated sherds extends some unknown distance to the south of the surface collection grid. The highest densities of decorated sherds are concentrated over a ca. $750 \mathrm{~m}^{2}(0.19$ acres) area centered on N100/E85 (see Figure 18).

\section{OVERALL CHARACTER OF THE DECORATED SHERDS FROM THE LEANING ROCK SITE}

Five decorative methods are well represented in the decorared ceramic vessel sherds from Leaning Rock: incised $(35.8 \%)$, brushed $(17.0 \%)$, engraved $(16.3 \%)$, punctated $(16.3 \%)$, and incised-punctated $(8.2 \%)$. The other $6.4 \%$ of the decorated sherds are comprised of 11 other decorative techniques (Table 9). The total proportion of brushed sherds in this assemblage is $21.5 \%$, including $8.4 \%$ of the rims in the collection. Almost $84 \%$ of the decorated sherds are from utility wares, including $83 \%$ of the rims.

More than $41 \%$ of the rims are from incised utility ware vessels, followed by punctated $(17.6 \%)$ and incisedpunctated $(11.4 \%)$ rims from other vessels. Fine ware sherd rims comprise $16.8 \%$ of the rim sample, and fine wares account for $18.2 \%$ of all of the Leaning Rock sherds. 


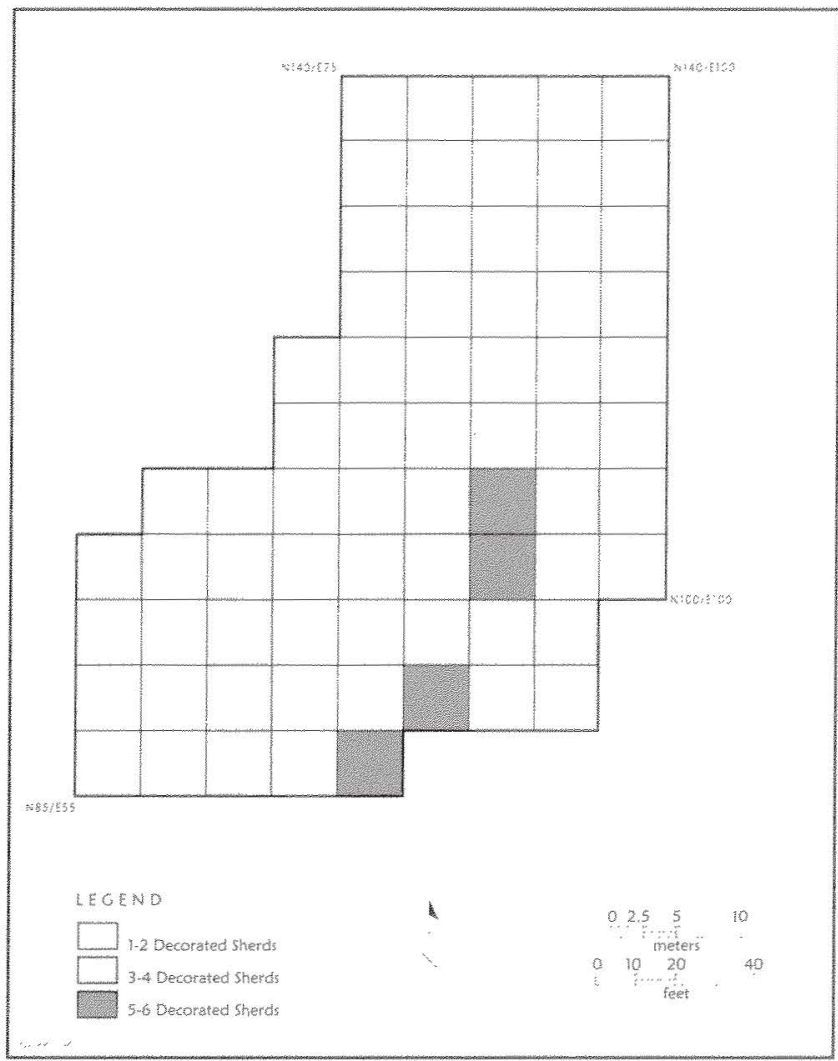

Figure 18. Distribution of decorated sherds.

Table 9. Decorated sherds from the Leaning Rock site (4ISM325).

\begin{tabular}{|lccc|}
\hline Decorative Method & Rim & Body & N \\
\hline Incised & 54 & 194 & 248 \\
Brushed & 6 & 112 & 118 \\
Punctated & 23 & 90 & 113 \\
Engraved & 22 & 91 & 113 \\
Incised-Punctated & 15 & 42 & 57 \\
Brushed-Punctated & 4 & 10 & 14 \\
Brushed-Incised & 1 & 12 & 13 \\
Washington Square Paneled & 3 & 1 & 4 \\
Pinched & 1 & 2 & 3 \\
Red-slipped & 0 & 2 & 2 \\
Appliqued & 1 & 1 & 2 \\
Brushed-Pinched & 0 & 2 & 2 \\
Brushed-Appliqued & 0 & 1 & 1 \\
Appliqued-Punctated & 0 & 1 & 1 \\
Brushed-Incised-Punctated & 0 & 1 & 1 \\
Lip notched & 1 & 0 & 1 \\
\hline & & & \\
\hline Totals & 131 & 562 & 693 \\
\hline
\end{tabular}




\section{DESCRIPTION OF DECORATED SHERD ASSEMBLAGE FROM THE LEANING ROCK SITE}

There are five principal decorated sherd categories at the Leaning Rock site: incised $35.5 \%$ of all decorated sherds and $41.2 \%$ of the decorated rim sherds), brushed $(17.0 \%$ and $4.6 \%$, respectively), punctated (16.3\% and $17.6 \%$, respectively), engraved (16.3\% and $16.8 \%$ of the rims), and incised-punctated $(8.2 \%$ and $11.4 \%$ of the rims). Utility wares are much more common in the sherd assemblage when compared to the engraved fine wares. In the discussions that follow of the decorated wares, beginning with the fine wares, I focus primarily on the decorative elements apparent on the rim of the vessel because at least on these sherds the orientation and relationship of decorative elements is apparent. I do not overlook the body sherds, however, since prehistoric Caddo potters are well known to have decorated rims differently from the body on many vessels--when the body is actually decorated, which it usually is by Middle Caddo period times-and this analysis is intended to fully characterize the stylistic diversity in Caddo vessel decorations as discerned from the Leaning Rock site sherds.

\section{Fine Wares}

The 119 fine ware ceramic vessel sherds (including 25 rims) are either engraved, paneled (Washington Square Paneled, see Hart 1982), or slipped. As in other prehistoric and historic Caddo vessel sherd assemblages in East Texas, the fine wares are dominated by the engraved vessel sherds.

\section{Engraved bowl and carinated bowl sherds}

Engraved rim sherds have geometric, panel, and curvilinear elements. The less complicated decorative elements at Leaning Rock include sets of horizontal engraved lines $(n=6,27 \%)$, cross-hatching $(n=3,14 \%)$ (Figure 19e), opposed (Figure 19d), and diagonal lines (single or multiple lines, $n=2,9.1 \%$ ). There are two rims with horizontal engraved lines that have a series of long diagonally ticked lines: these distinctive rims have been classified here as Leaning Rock Engraved. One other rim has sets of horizontal engraved lines with excised pendant triangles (Figure 19a), and another simply has excised triangles. There is a rim from Unit $9(10-20 \mathrm{~cm}$ bs) that has a vertical engraved panel with at least one triangular hatched corner, similar to engraved decorative treatments on some varieties of Poynor Engraved.

About $27 \%$ of the rims have curvilinear or semi-circular engraved motifs/elements. The most distinctive rim (Unit $3,20-30 \mathrm{~cm}$ ) has a rayed and hatched circle element next to a negative S-shaped scroll (see Figure 19f). This scroll element has a series of hatched pendant triangles.

Two engraved rims have large semi-circular elements, either open or filled with hatched lines. The three curvilinear engraved rims have sets of concentric curvilinear lines (see Figure 19i), and one has a hatched engraved ladder on the rim above large curvilinear elements (see Figure 19b).

Engraved body sherds from bowls and carinated bowls indicate that fine ware vessels have primarily geometric designs. These include opposed engraved lines ( $n=8$ ), parallel (i.e., horizontal or vertical, $n=12$ ), and crosshatched ( $n=9$ ). One other has a cross-hatched panel, and two have diagonal lines. There is one Leaning Rock Engraved sherd with a series of short parallel lines on it.

Other common engraved elements include narrow hatched panels $(n=4)$. Iadders $(n=2)$, or opposed and hatched elements $(n=1)$. A different body sherd has engraved chevrons on it, and one unique sherd has both parallel 


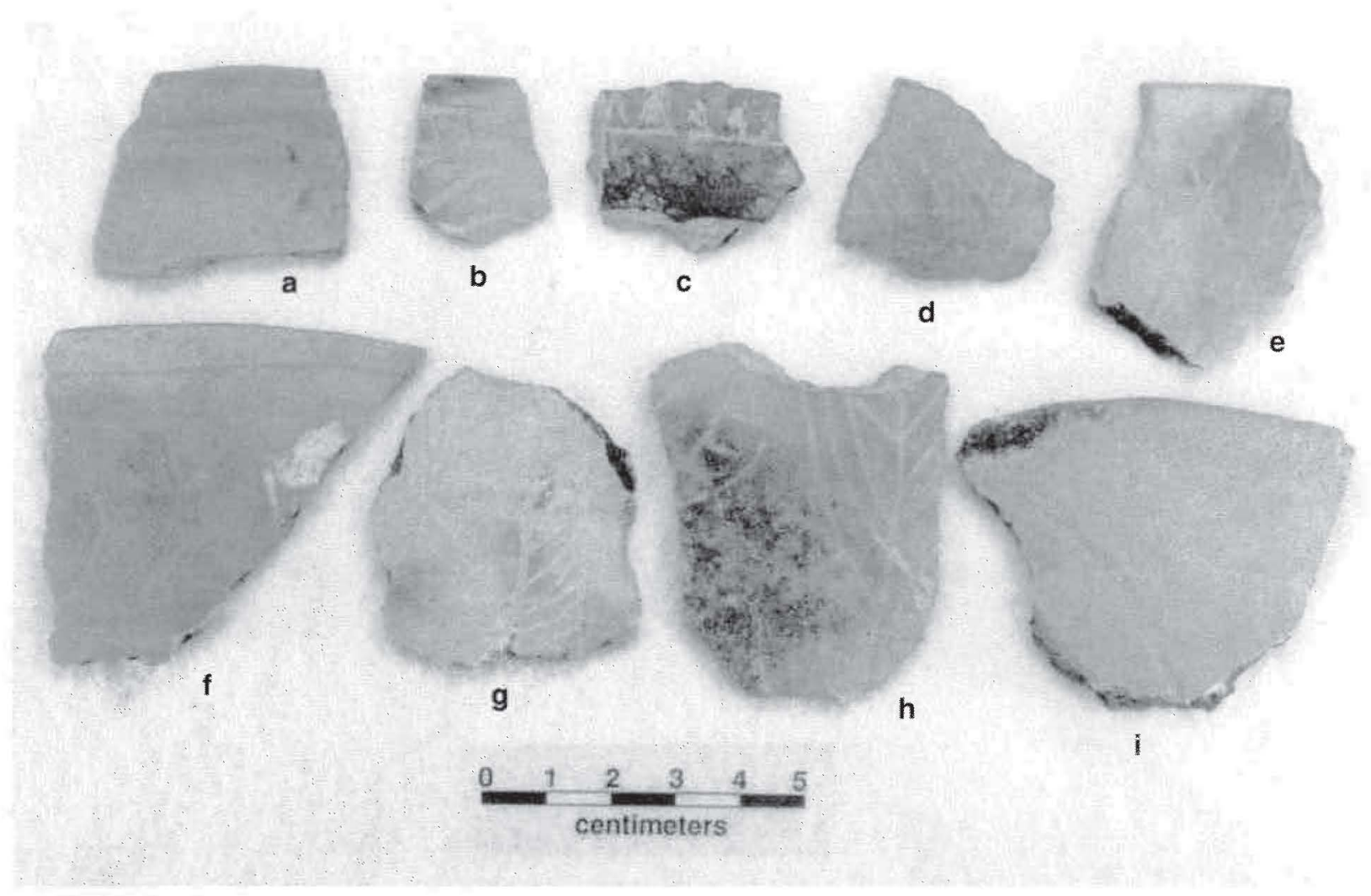

Figure 19. Engraved rim and body sherds: $a-f, i$, carinated bowl sherds; g-h, bottle sherds. Provenience: a, Unit 10, Iv. $5 ; b$, Unit 12, Iv. 4; e, Feature 5, Iv. 9; d, Unit 2, Iv. 3; e, Unit 1, lv. 3; f, Unit 3, Iv. 3; g, Unit 12, Iv. 3; h, Feature 2; 1. Unit 10. Iv. 3.

engraved lines and a rectilinear oval surrounded by a cross-hatched zone. Six body sherds have excised triangular elements. Five have a row of excised triangles above or below a single horizontal engraved line (see Figure 19c), probably placed along the rim-body juncture.

Curvilinear engraved lines are only infrequently seen on bowls and carinated bowls $(n=6)$ from the Leaning Rock site.

\section{Engraved bottle sherds}

There are 28 engraved bottle sherds at Leaning Rock. Certainly the most distinctive are two body sherds with portions of engraved rattlesnake motifs on them. One (Feature 2,30-44 cm bs) appears to have part of the rattlesnake head with two eyes (see Figure 19h), and the other is a cross-hatched chevron from the body of the rattlesnake. The rattlesnake sherds from Leaning Rock are part of the Sabine cluster of engraved rattlesnake vessels defined by Walters (2006: Figures $30 \mathrm{~b}$ and 31 ).

Other engraved bottle sherds include sets of straight $(n=1)$, parallel $(n=4)$, or curvilinear lines $(n=4)$, usually closely spaced on the bodies of bottles. More complicated bottle elements have combinations of horizontal and curvilinear sets of engraved lines $(n=2)$ or opposed engraved lines $(n=2)$. One curvilinear engraved bottle sherd has pendant triangles on one of the lines, and a more distinctive engraved bottle element on another sherd-resembling the decorative elements on Nacogdoches Engraved vessels (see Hart 1982)--has a cross-hatched zone adjacent to curvilinear lines. 
Five bottle sherds have either hatched or cross-hatched triangle elements, cither by themselves as part of a chevron design, or as an excised triangular element pendant from parallel engraved lines.

The remaining engraved bottle sherds have hatched elements. These include hatched triangles pendant from straight ( $n=2$ ) or curvilinear lines ( $n-1)$; opposed curvilinear and hatched engraved lines $(n=1)$; along with one panel element filled with hatched lines (see Figure $19 \mathrm{~g}$ ).

\section{Use of red clay pigments}

Approximately $8 \%$ of the engraved sherds have a red hematite-rich clay pigment that has been smeared in the engraved decoration. Almost $90 \%$ of these sherds are from bottles, while the other is from a carinated bowl with a distinctive rayed circle and S-shaped scroll motif (see Figure 19f). Roughly similar proportions of red pigment use on engraved pottery has been documented at the Nawi haia ina site $(7.7 \%$, Perttula and Nelson 2003) and Oak Hill Village (3.5\%, Pertula 2004), and pigment use was common (although unquantified) at the Redwine site (Walters et al. 1998:10). Campbell (1936: Table 7) noted the regular use of both red and white clay pigments in his study of decorated Caddo ceramic vessels from East Texas, with $14 \%$ of decorated Caddo vessels in the region having pigmented designs.

\section{Washington Square Paneled sherds}

There are four Washington Square Paneled vessel sherds (including three rims) from the Leaning Rock site. This type was defined by Hart (1982:71) from sherds and vessels recovered from Middle Caddo period archeological deposits at the Washington Square Mound site (4INA49) in Nacogdoches County, Texas.

The type has rectangular rim panels (either straight or convex-sided) decorated either by incised, engraved, or punctated lines, and the space between the rectangular panels is filled with the same decorative elements (Hart 1982: Figure 3-12). The Leaning Rock Washington Square Paneled sherds have incised or engraved panels filled with fingernail punctates (Figure 20a-c). The three rims have a pie crust shape (i.e. peaks and scallops) with distinctive vertical incised lines or punctations above the panels and below the lip (Figure 20d). There is an engraved bowl and a plain vessel with similar pie crust rims from the Redwine site (4ISM193, Walters et al. 1998:12,26 and Figure 11i) and 4IRK276, another Middle Caddo site in the middle reaches of the Sabine River basin (Pertula 200la: Figure 32). Suhm and Jelks (1962:Plate 39g) illustrate a Holly Fine Engraved vessel from the George C. Davis site, on the Neches River, with a pie crust rim.

\section{Red-slipped sherds}

Both slipped sherds from the Leaning Rock site are body sherds from carinated bowls that have an exterior hematite-rich clay slip. Slipped sherds-from either carinated bowls or bottles--are rare in studied Middle Caddo sites in the middle reaches of the Sabine River basin, not amounting to even $1 \%$ of the decorated sherds (see below). This contrasts markedly with upper Sabine and upper Cypress basin Middle Caddo sites where red-slipped vessels can comprise more than $10 \%$ of the decorated sherds in a ceramic vessel assemblage.

\section{Lip notched}

One rim from Feature $3(50-88 \mathrm{~cm}$ bs) has regularly spaced notching along the lip. The vessel rim is otherwise plain. The lip notches are spaced at $5.4 \mathrm{~mm}$ intervals along the lip, and are short and perpendicular to the lip. 

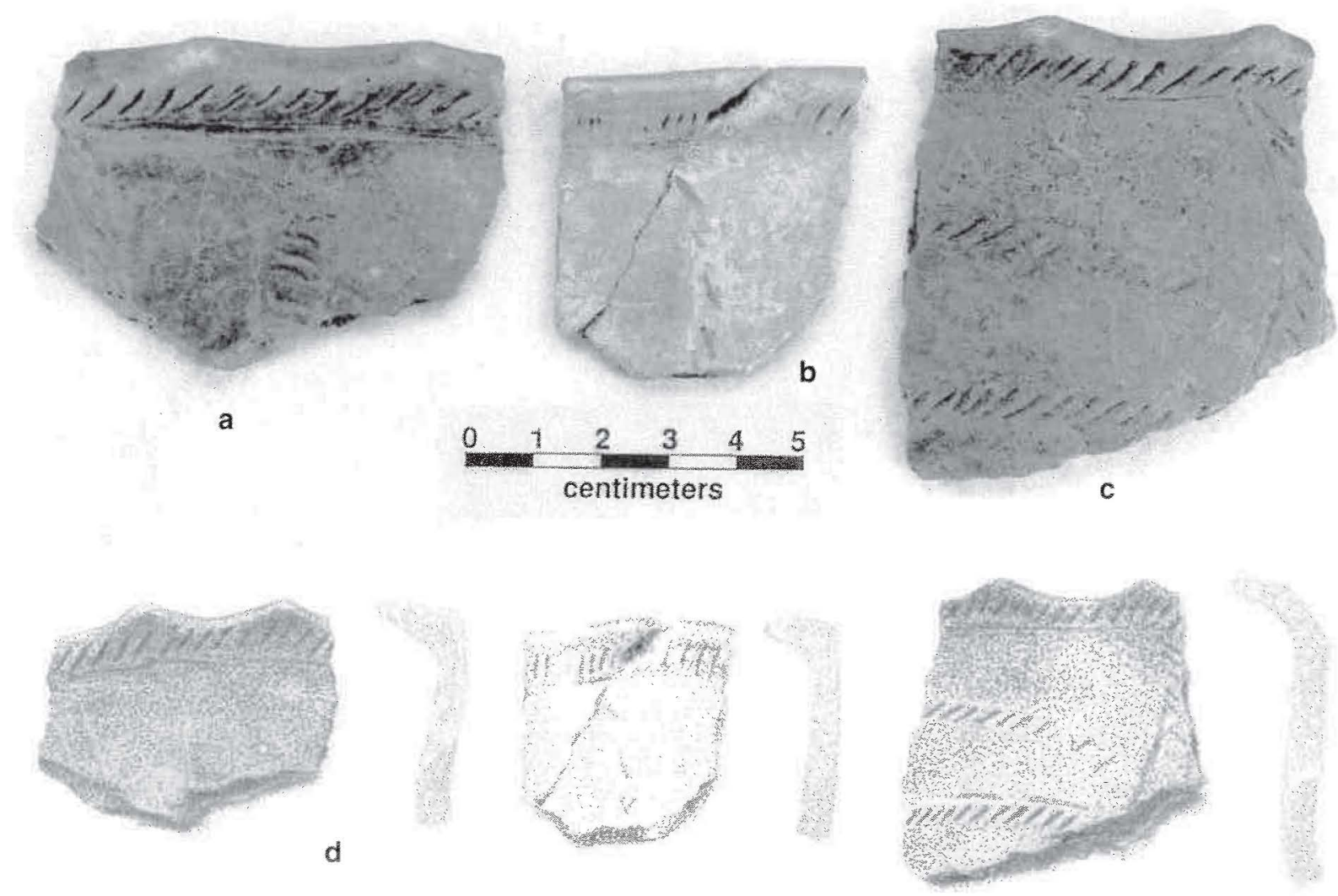

Figure 20. Washington Square Paneled sherds from Leaning Rock. Provenience: a, Unit 4, Iv. 4; b, Unit 9, Iv. 3; c, Unit 11, Iv. $3 ; \mathrm{d}_{4}$ drawings of Washington Square Paneled rims and rim/lip profiles, by Bryan Boyd.

Lip notching is a relatively rare lip treatment in Middle and Late Caddo vessels on Caddo sites in the Sabine, Neches, and Big Cypress drainages in East Texas. For example, at the contemporaneous Nawi haia ina site (41RK170) in Rusk County, 2.5\% of the rims in the assemblage are lip notched (Perttula and Nelson 2003: $96-97,103)$.

\section{Utility Wares}

There are 574 utility ware sherds in the Leaning Rock ceramic vessel assemblage. As mentioned above, this is approximately $83 \%$ of all the decorated sherds from the site. Other contemporaneous Caddo sites in the middle part of the Sabine River basin have similar proportions of utility wares (78-93\%). Sherds from vessels decorated with incised lines, tool or fingernail punctates, brushing marks, or incised-punctated elements are the most abundant utility wares at Leaning Rock, as they are at other Middle Caddo sites in this region.

\section{Incised sherds}

There are a variety of relatively simple incised decorative motifs on utility ware vessel rims from the Leaning Rock site. By far the most common are cross-hatched incised lines $(n=27,50 \%)$ (Figures 21 and 22a, $c$ )including several with cross-hatched incised panels defined by a single horizontal incised line at the base of the rim. Also popular are rims with sets of diagonal incised lines pitched either to the left or right $(n=14,26 \%)$ and sets of diagonal opposed incised lines $(n=6,11 \%$ ) (Figure $22 \mathrm{~d}$ ). Four rims $(7.4 \%)$ have sets of horizontal incised lines (Figure 22b), and three (5.5\%) have multiple diagonal opposed lines. 


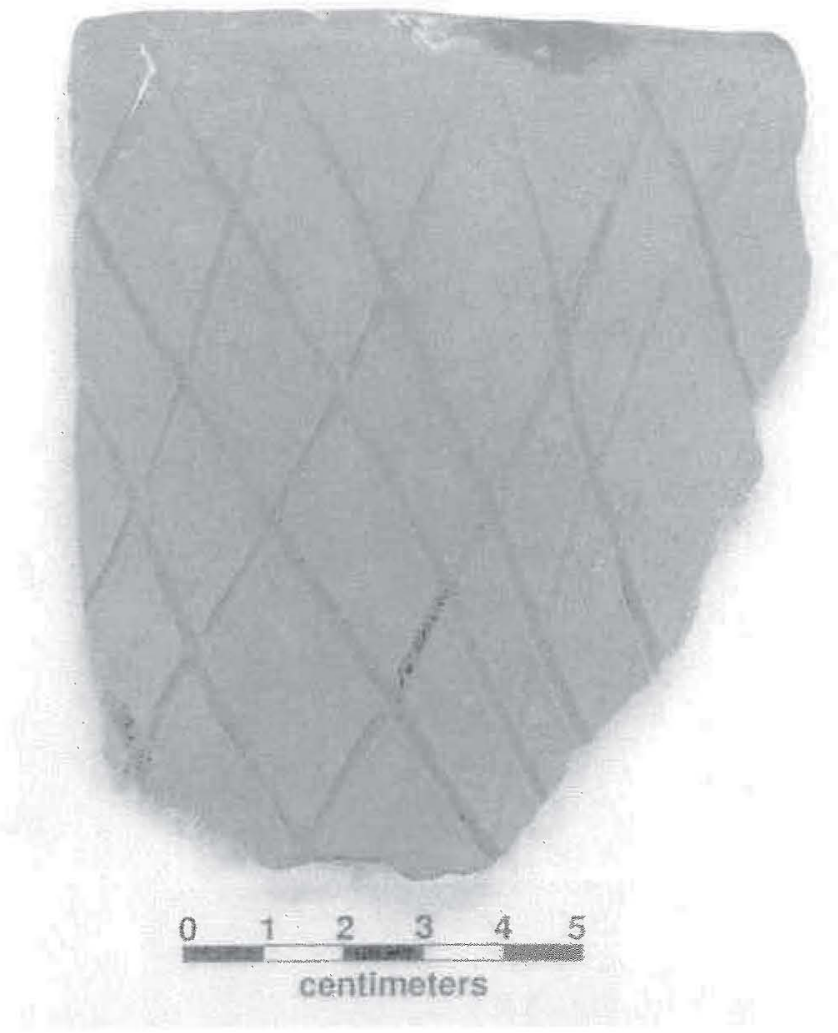

Figure 21. Cross-hatched incised rim, Unit $11,23 \mathrm{~cm}$ bs.

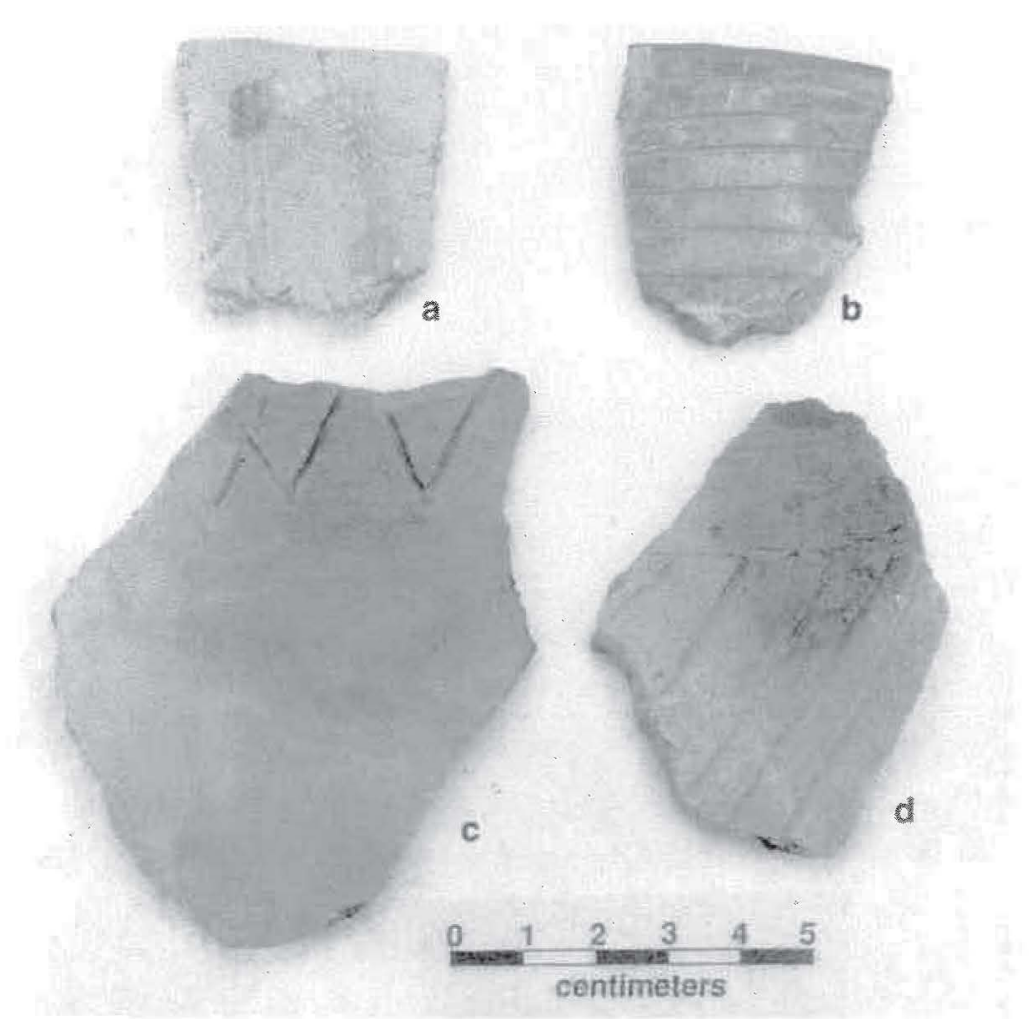

Figure 22. Incised rim and body sherds. Provenience: a, Feature $5.1 \mathrm{v}, 10 ; \mathrm{b}$, Unit 1, Iv, 6; c, Unit 12, $26 \mathrm{~cm}$ bs; d, Unit II. IV. 3. 
The body sherds (or the lower part of the rim itself) from utility ware vessels indicate that most of them were decorated with cross-hatched $(n=78)$ or opposed $(n=37)$ incised lines. A few have cross-hatched incised panels placed above a single horizontal incised line $(\mathrm{n}=8)$ that must have encircled the vessel at the rimbody juncture. Sets of horizontal incised lines, spaced either closely or widely apart, on vessels are marked by 33 body sherds with parallel lines. Only one body sherd has diagonal incised lines, and five others have curvilinear lines.

\section{Brushed Sherds}

Brushed vessels are jars that have brushing marks covering both the rim and body. At Leaning Rock, it is apparent that the brushing on utility ware vessels is often accompanied by other forms of decoration on either the rim or the body (see below).

On the rim, the brushing is primarily horizontal (Figure 23a), but there is one rim with diagonal brushing marks. On the bodies of brushed vessels, the brushing marks (made with grasses or frayed sticks) are usually parallel to each other (Figure 23b-d)-most likely with a vertical orientation and extending to the vessel base-but occasionally the brushing marks are overlapping or partially smoothed over.

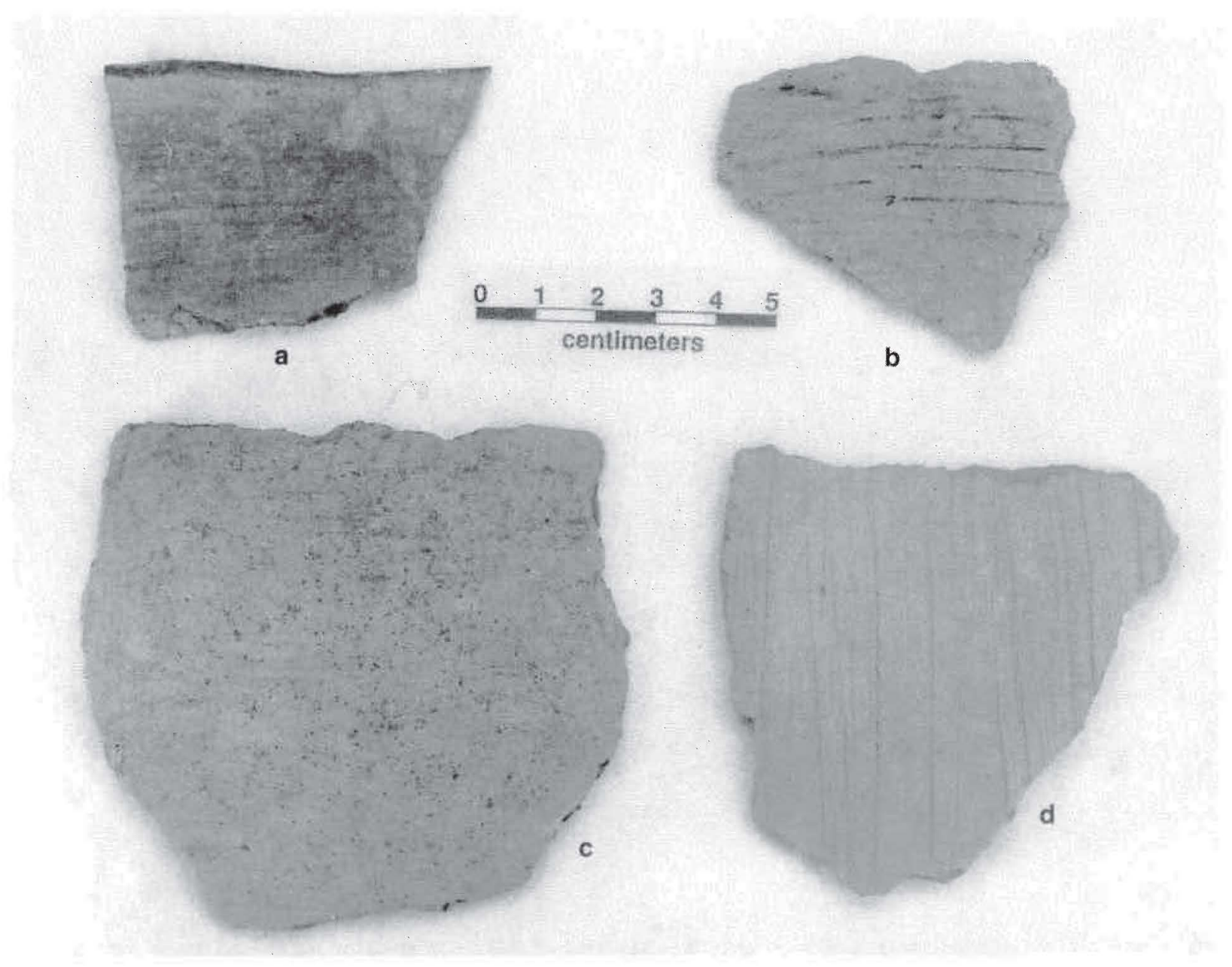

Figure 23. Brushed sherds: a, horizontal brushed tim; b-d, parallel brushed body. Provenience: a. c, Unit 11, Iv. 3; b. Unit 13. IV. 4: d. Unit 11. IV. 2 . 


\section{Punctated sherds}

Punctated vessels at the Leaning Rock site have rows of tool $(n=17)$, fingernail $(n=3)$, and cane $(n=3)$ punctates (Figure 24a-d). In most cases, the punctations occur in horizontal rows across the rim or under the lip, but there are also diagonal rows on the rim $(8.7 \%)$ or sets of horizontal and vertically-oriented tool punctations.

Among the body sherds, approximately $96 \%$ have rows of tool punctations. These rows probably covered most, if not all, of the body surface of utility ware vessels. The few remaining punctated body sherds have fingernail $(2 \%)$ or cane punctated $(2 \%)$ elements.

\section{Incised-Punctated sherds}

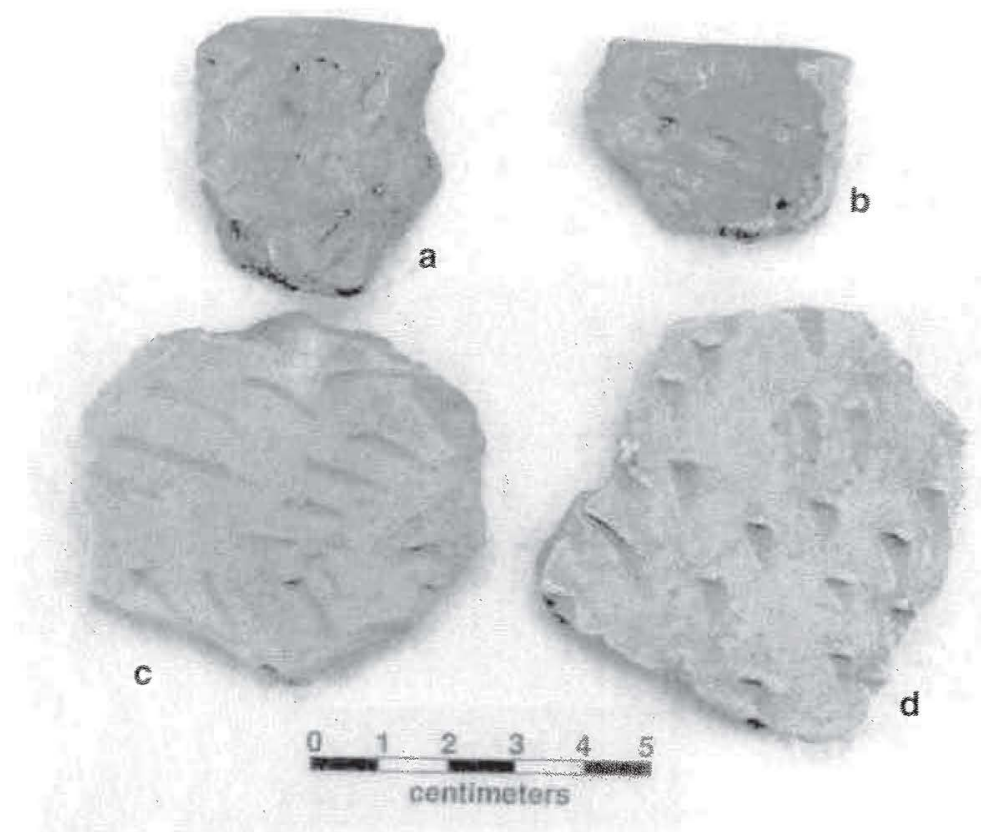

Figure 24. Punctated sherds: $a, d$, tool punctated; $b$, cane punctated; c. fingernail punctated. Provenience: a, Feature $5,65-75 \mathrm{~cm}$ bs; $b$, Unit 12 Iv. 5; c, B39, surface; d, Unit 2, 1v. 3.

Most of the incised-punctated vessel

rims $(n=10,66.7 \%)$ have triangular incised zones filled with tool punctations. The incised triangles are either pendant from the rim or pendant from the rim-body juncture, and may alternate in orientation along the rim. The tool punctated-filled zones have at least one or two diagonal or sets of opposed incised lines separating each of the triangular punctated zones (Figure $25 \mathrm{a}_{4} \mathrm{c}-\mathrm{d}$ ).

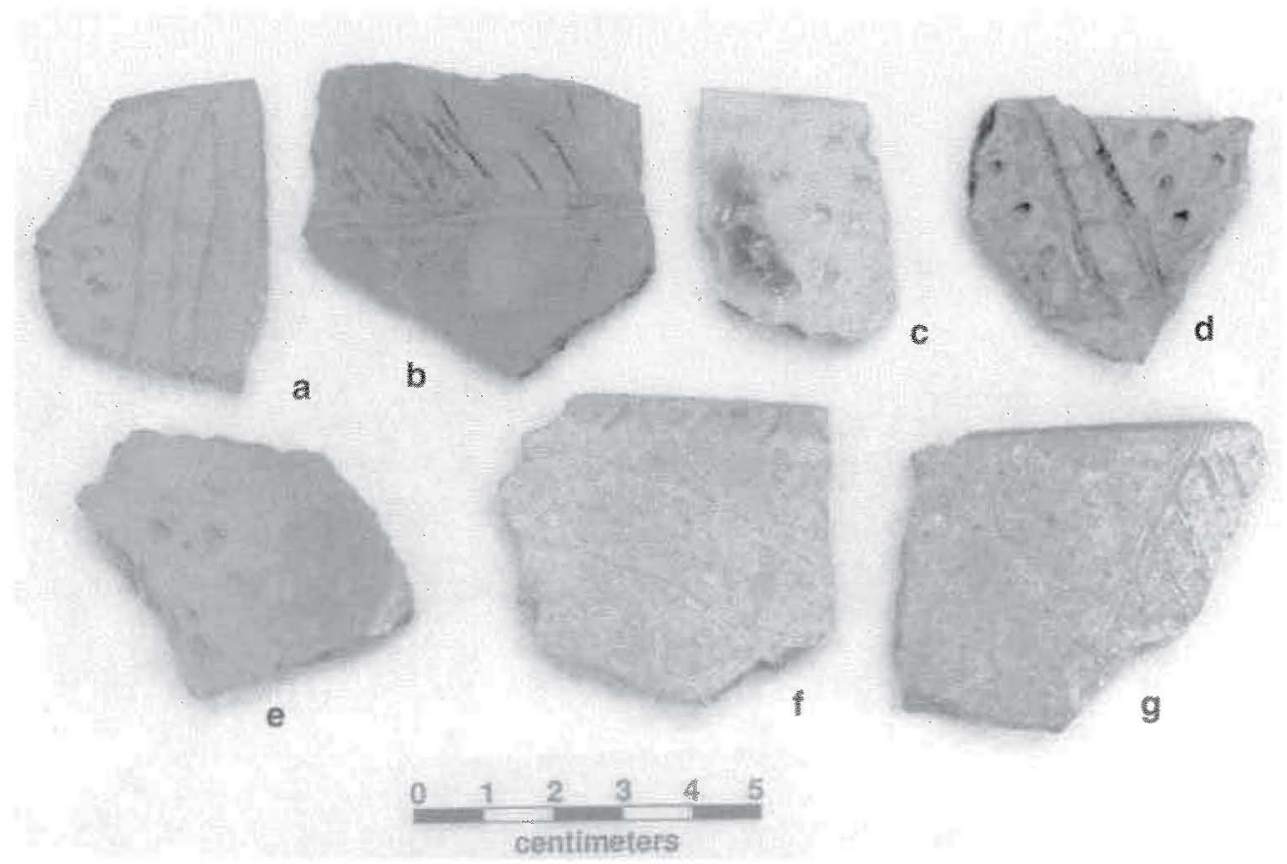

Figure 25. Incised-punctated rim and body sherds. Proventence: a, Unit 8, Iv, 3; b, B62, surface: c. Unit 1, W. 4: d, Unit 13, Iv. 4: e, Unit 4, Iv. 4; f, Feature 5, Iv. 9: ynit 12, Iv. 4. 
A second but decidedly minor decorative motif among the incised-punctated sherds includes horizontal rows of tool punctations separated by horizontal incised lines $(n=2,13.3 \%)$. Another incised-punctated rim decoration includes sets of vertical incised panels between rectangular areas filled with tool punctations (see Figure 25e). Two other rims have sets of circular or curvilinear incised lines, along with tool punctated zones dividing the circular incised elements (see Figure 25f). At least one body sherd has a series of concentric circles around a tool punctated circle.

Decorated incised-punctated body sherds are predominantly comprised of triangular incised zones (76\%) filled with tool punctates (72\%). Fingernail punctated (19\%) (see Figure $25 \mathrm{~b}$ ) or cane punctated $(9 \%)$ elements are much less popular in the Leaning Rock pottery, as are circular or curvilinear motifs (19\%) or incised-punctated panels $(5 \%)$.

\section{Brushed-punctated sherds}

Brushed-punctated utility ware vessels at the Leaning Rock site are decorated in two different ways. The first consists of parallel or horizontal brushing decorations with rows of tool or fingernail punctated rows pushed through the brushing. Other vessels have brushing (horizontal or diagonal brushing marks) on the rim and body, with tool punctated rows under the lip and at the rim-body juncture, as well as pushed through the brushing on the rim (Figure 26a-b). One body sherd has vertical panels of brushing divided by a single row of tool punctates.

\section{Brushed-incised sherds}

The potters at Leaning Rock decorated utility ware vessels with brushed and incised decorations on both the body and the rim. The one rim sherd has horizontal brushing marks with overlying diagonal incised lines. The vessel bodies typically have parallel (i.e., vertical) brushing-incised lines, but two have opposed brushing marks overlaid with opposed incised lines (Figure 27b).

\section{Pinched sherds}

The pinched rim and body sherds are from two units between $10-40 \mathrm{~cm}$ bs. The rim has vertical pinched ridges on

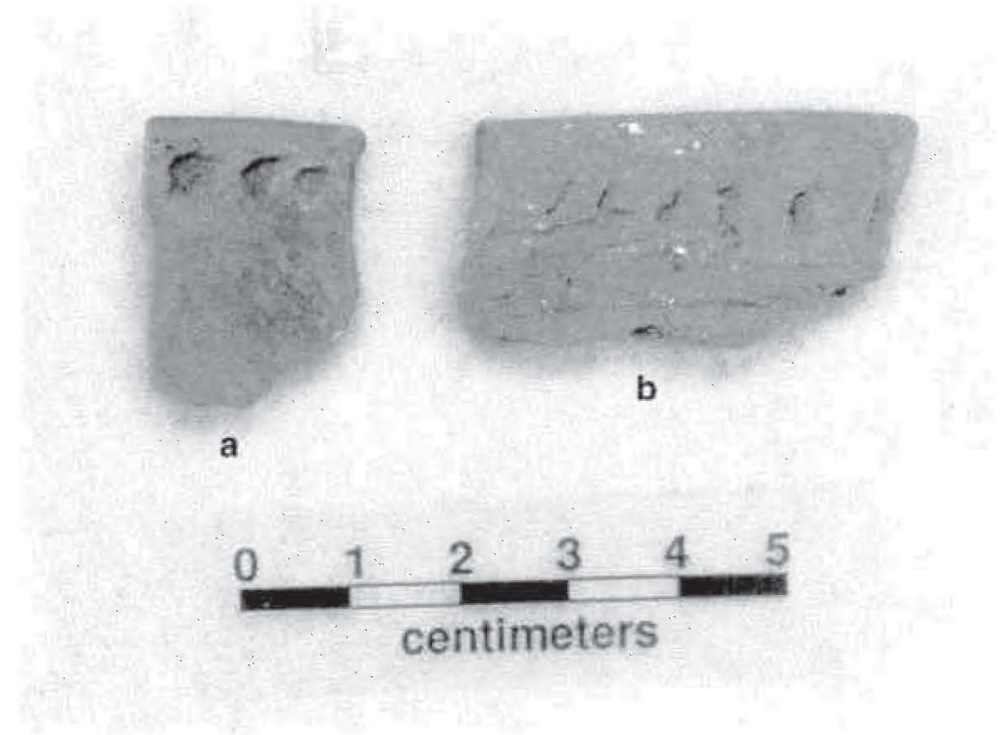

Figure 26. Brushed-punctated rim sherds. Provenience: a, Unit 9, Iv. 4; b, Unit 12, Iv. 2. it, while one of the body sherds has both vertical and curvilinear pinched decorative elements (see Figure 27a). These sherds are probably from two different Killough Pinched jars.

\section{Appliqued sherds}

One small jar rim from the surface has an appliqued node on the lip (see Figure 27d). The rim is interior beveled along the lip, suggesting it has a pie crust or scalloped lip. The appliqued body sherd consists of a single straight appliqued ridge with tool punctations on it (see Figure 27f). 

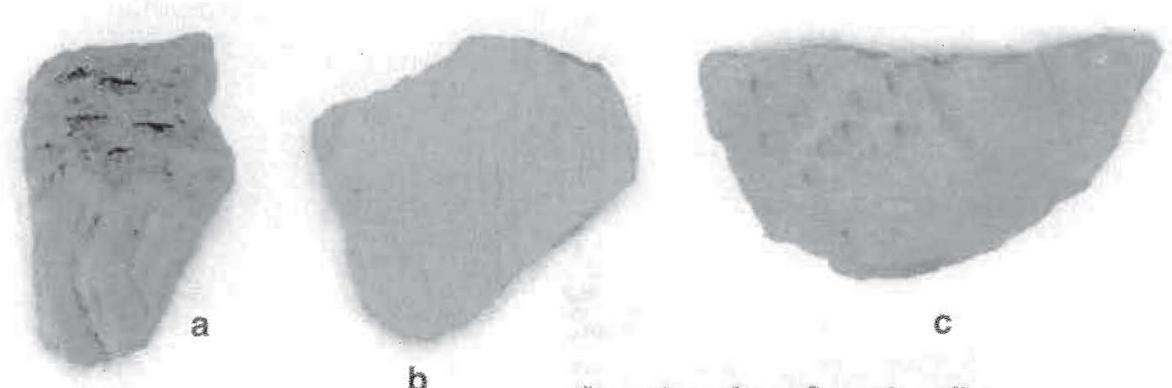

$\mathrm{c}$

b
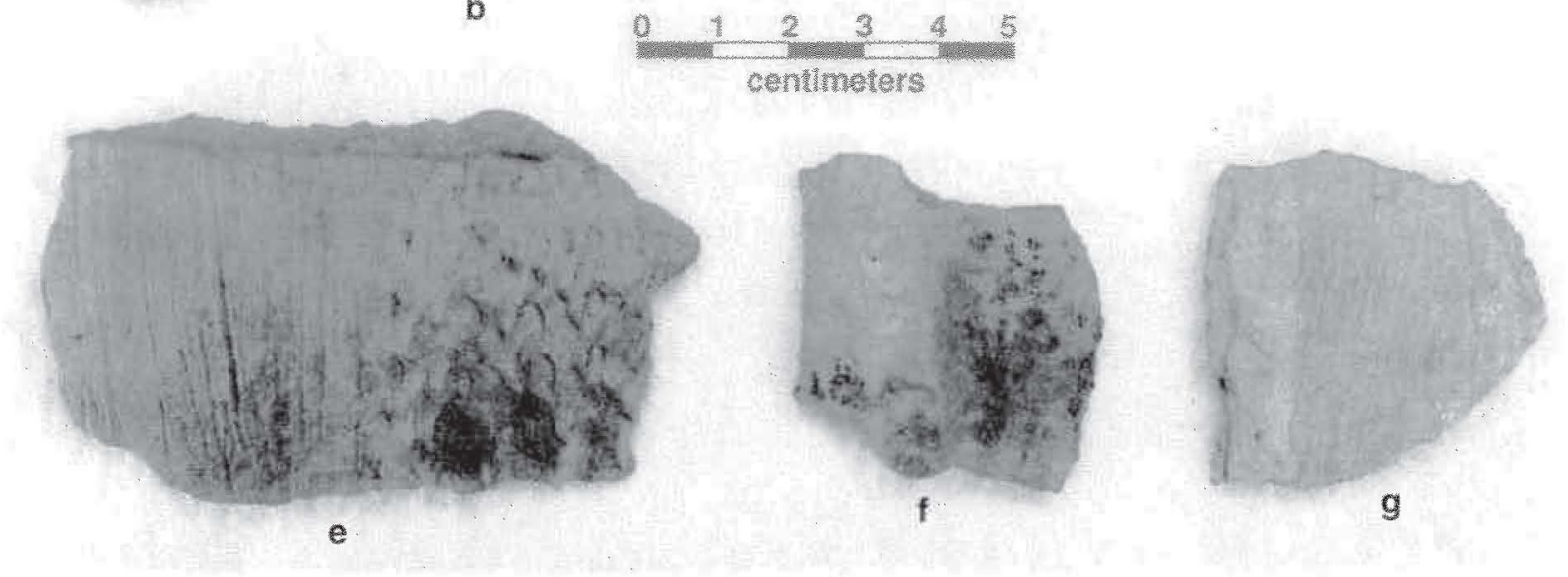

Figure 27. Other decorated utility ware sherds: a, pinched; b, brushed-incised; c, brushed-incised-punctated; $\mathrm{d}, \mathrm{f}$, appliqued; e, brushed-pinched; g, brushed-appliqued. Provenience: a, Unit 4, Iv, 4; b, Unit 11, Iv, 4; c, Unit 5, Iv, 1; d, Surface; e, Unit $2,1 v, 3 ; \mathrm{fig}$, Unit 11, lv. 3 .

\section{Brushed-pinched sherds}

Two body sherds have distinctive brushed-pinched decorations on the bodies of utility ware jars. The vessel decoration consists of vertical brushing and vertical pinched ridges that probably extend from the rim-body juncture to near the base. One of the body sherds has a vertical row of tool punctations that effectively divides the vessel body into distinct brushed or pinched panels (see Figure 27e).

\section{Brushed-appliqued sherds}

The one body sherd with a brushed-appliqued decoration has parallel brushing marks on either side of a single straight appliqued fillet (Unit 11,20-30 cm bs) (see Figure 27g). It is likely that the brushing ran vertically on a jar, and the jar body was partitioned by vertical appliqued fillets, dividing the vessel body into panels filled with brushing marks.

\section{Appliqued-punctated sherds}

One jar sherd (Unit 11,20-30 cm bs) has an appliqued-punctated decoration on the vessel body; the rim decoration is not known. This sherd has a vertical and straight appliqued ridge with a series of tool punctations on the ridge. There is also at least one diagonal tool punctated row adjacent to the appliqued ridge.

\section{Brushed-incised-punctated sherds}

The brushed-incised-punctated sherd (Unit $5,0-10 \mathrm{~cm}$ bs) is from a jar with horizontal brushing marks on the body and an incised punctated motif on the rim (see Figure $27 \mathrm{c}$ ). This motif consists of opposed sets of diagonal 
incised lines that have created triangular zones filled with rows of cane punctations. This is a cooking jar based on the preserved organic residue on the interior sherd surface.

\section{PLAIN RIM SHERDS}

There are 130 plain rim sherds in the Leaning Rock ceramic sherd assemblage. This is indicative of the fact that plain wares comprise a significant part of the ceramic vessels in use during the Caddo occupation. The ratio of plain to decorated rims is $1: 1(130: 131)$.

Plain rims come from the surface $(n=13)$, features $(n=14 ; 13$ are from Feature 5 and the other is from Feature $3)$, and hand excavation units ( $\mathrm{n}=103)$. The plain rims in the surface collection are found along the margins of the spatial distribution of the decorated sherds (Figure 28), but the sample of surface sherds is small.

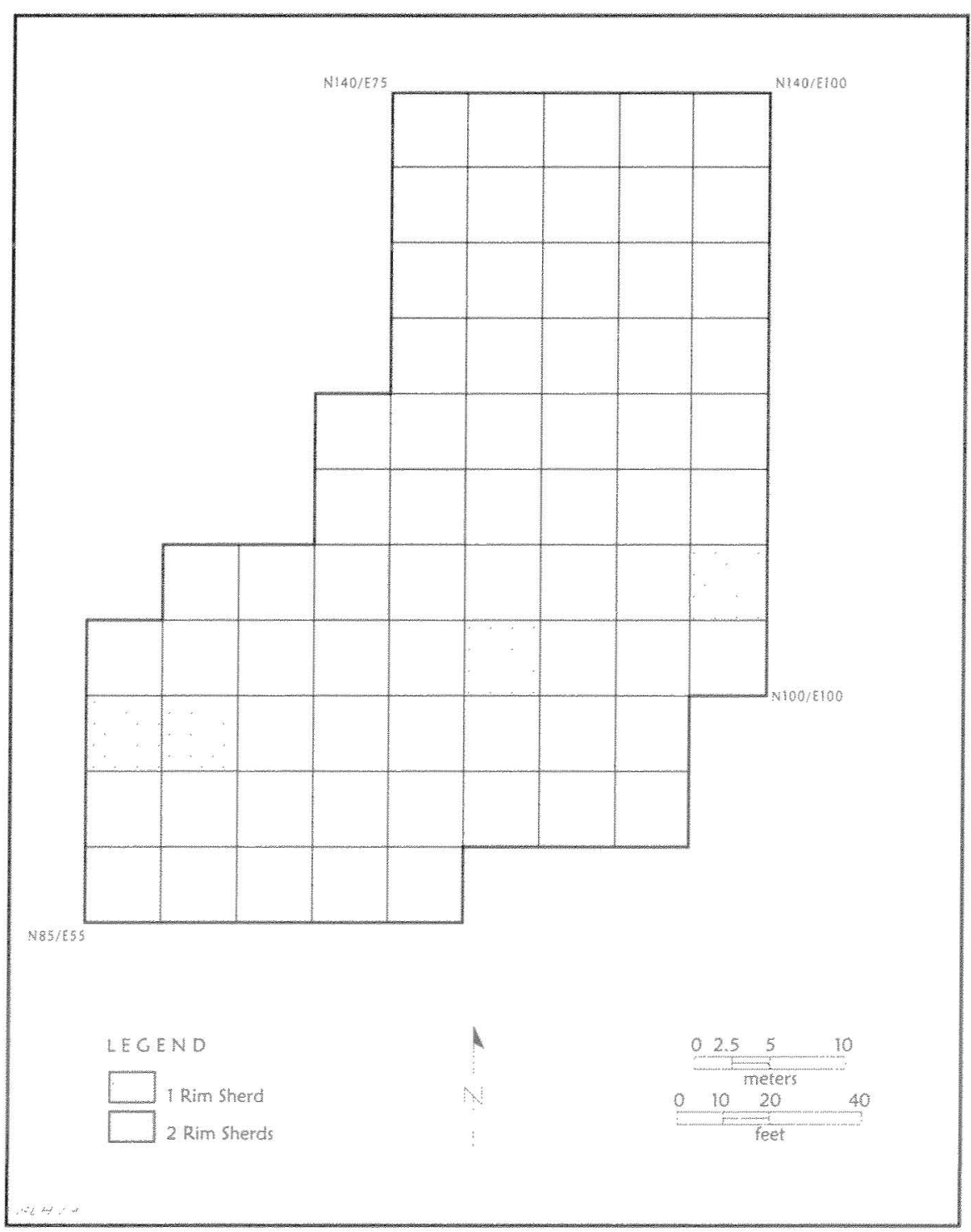

Figure 28. Distribution of plain rim sherds in the surface collection. 


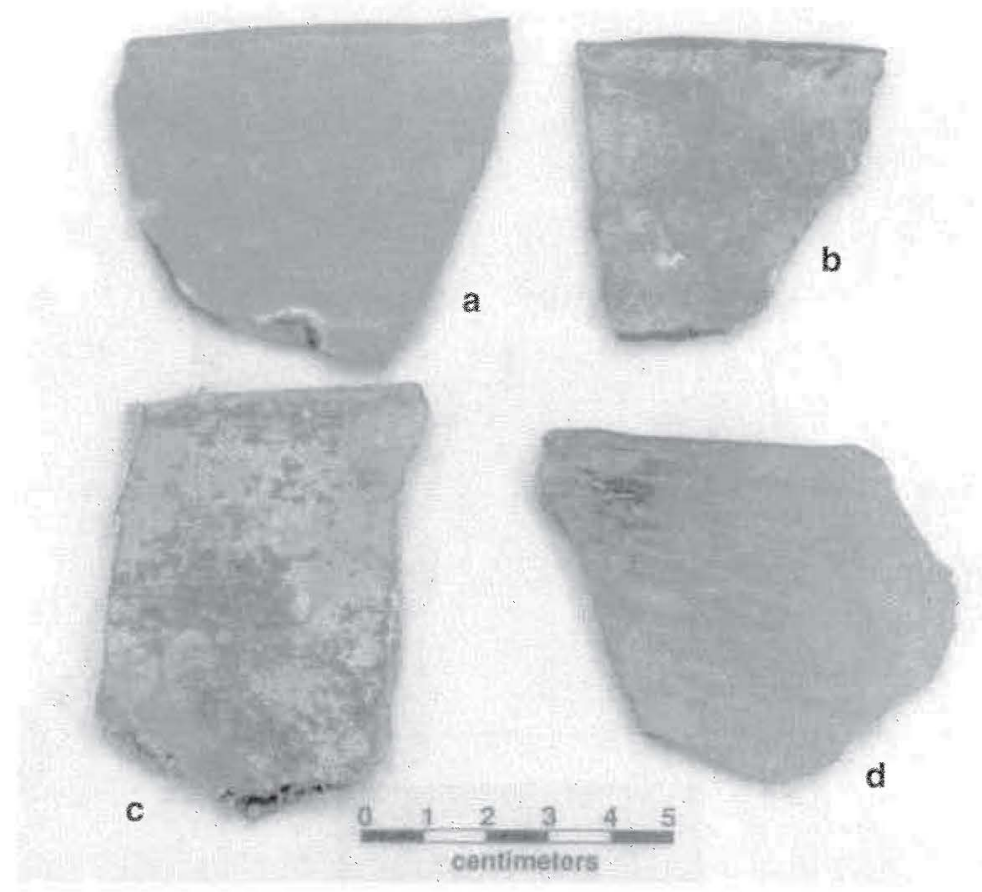

Figure 29. Plain tim sherds. Provenience: a, Unit 9, Iv. 3; b, Unit 1, Iv, 6; c, Unit 1, 1v. 4; d, Unit 6,29 cm bs.

burnished on both interior and exterior surfaces (Figure 30a-b). The rim is direct with a flat lip, and the vessel has a flat disk base.
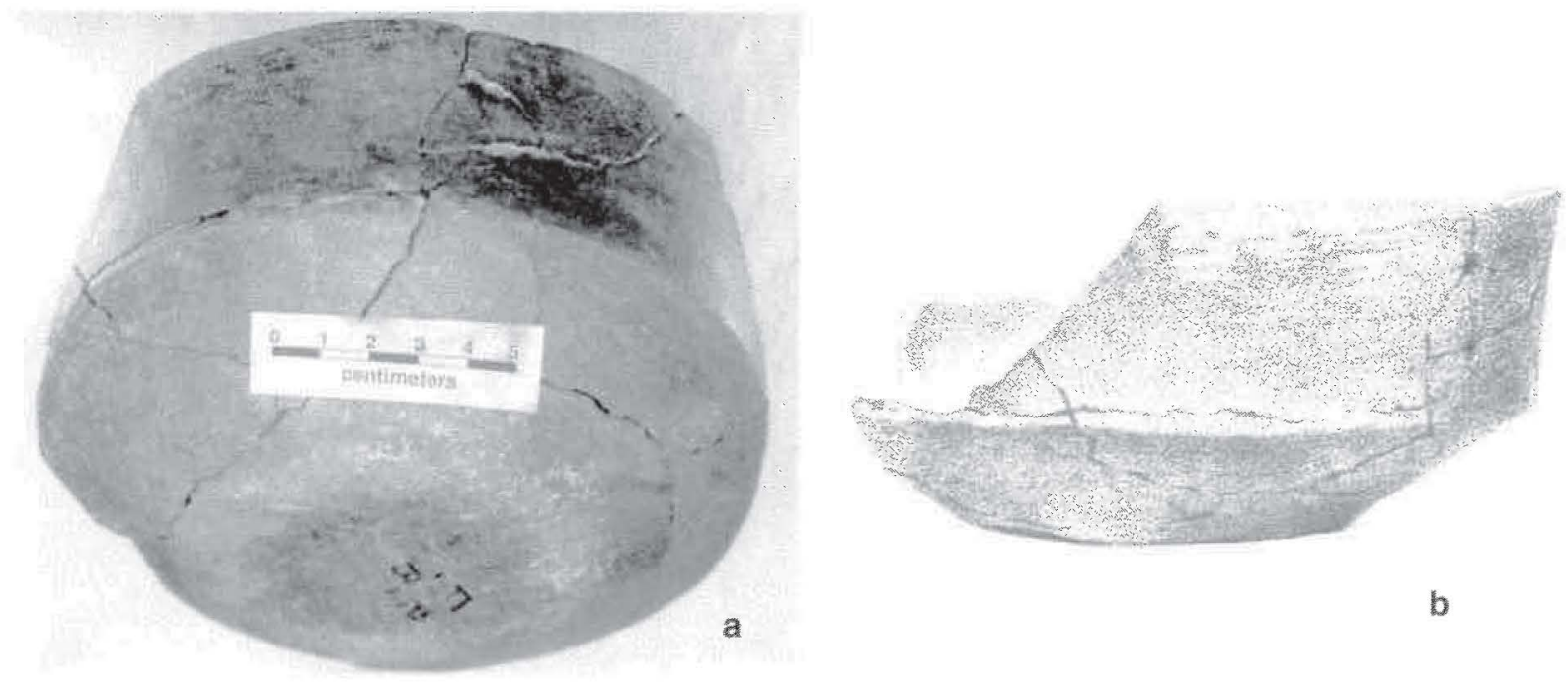

Figure 30. Plain carinated bowl from Feature 2: a, photograph; b, drawing by Bryan Boyd.

\section{ORIFICE DIAMETERS FOR PLAIN AND DECORATED RIMS SHERDS}

Thirty of the tims (14 plain wares, three fine ware, and 13 utility ware) are large enough to measure the orifice diameter of the vessels they came from, and thus obtain some idea of the size and range in vessels 
used at the Leaning Rock site. There are two plain bottle neck rims with $5 \mathrm{~cm}$ orifice diameters (suggesting substantial-sized bottles), but the others are from jars, bowls, and carinated bowls (plain or decorated),

The plain and decorated vessels from Leaning Rock come in four different size groups, from small to very large (Table 10), and there are examples from each size group among the plain wares, fine wares, and utility wares. Large vessels are most common (36\%) among all the non-bottle rims, and are most common among the plain wares and utility ware rims. The only very large vessel rim sizes occur in the utility wares; these are probably decorated storage vessels.

Table 10. Orifice diameters on measurable rims from the Leaning Rock site.

\begin{tabular}{|lcccc|}
\hline $\begin{array}{l}\text { Vessel Size Category } \\
\text { (Orifice diameter) }\end{array}$ & Plain ware & Utility ware & Fine ware & $\mathrm{N}$ \\
\hline Small $(13-15 \mathrm{~cm})$ & 4 & 3 & 1 & 8 \\
Medium $(16-20 \mathrm{~cm})$ & 3 & 3 & 1 & 7 \\
Large $(22-27 \mathrm{~cm})$ & 5 & 4 & 1 & 10 \\
Very large $(33-34 \mathrm{~cm})$ & - & 3 & - & 3 \\
Totals & 12 & 13 & 3 & 28 \\
\hline
\end{tabular}

\section{USE OF TEMPER}

Grog (crushed sherds) is the preferred temper among the plain wares, utility wares, and fine wares (Table 11). Between $83-100 \%$ of the sherds examined in detail have grog temper, sometimes in combination with crushed bone, hematite, or charred organic materials. Grog temper is most commonly used in the plain wares and utility wares,

Table 11. Temper classes by ceramic wares.

\begin{tabular}{|lccc|}
\hline Temper Category & Plain ware & Fine ware & Utility ware \\
\hline grog & $52.1^{*}$ & 70.0 & 55.1 \\
grog-bone & 12.5 & 3.3 & 11.2 \\
grog-bone-hematite & 12.5 & 6.7 & 5.1 \\
grog-hematite & 20.8 & 3.3 & 19.4 \\
hematite & - & 6.7 & - \\
bone & - & - & 4.1 \\
bone-organics & - & - & 1.0 \\
grog-bone-organics & - & - & 1.0 \\
bone-hematite & - & -- & 2.0 \\
none & - & 30.0 & 1.0 \\
Totals & 24 & & 98 \\
\hline *percentage & & & \\
\hline
\end{tabular}


as are sherds tempered with bone (24-25\%) or hematite (26.5-33\%). The only sherds with charred organics in the paste are utility wares. Plain wares and utility wares have comparable tempering strategies used by Caddo potters, with coarser tempered pastes than the fine wares. The addition of angular pieces of bone and hematite would have made the clay paste in the vessels more plastic, would have helped to better bond the walls of the vessel together, limited the tendency for the later development of cracks during use, and increased their strength or use-life.

Not too surprisingly, bone and hematite temper was more abundant in the decorated utility wares and plain wares than they are in the decorated fine ware vessel sherds. The use of grog would have slowed the oxidation process of ceramic vessels during firing, allowing them to be fired longer, and producing a harder ceramic vessel. Grog temper in the paste would have also contributed to the ability of fired vessels to withstand heat-related stresses and increase their flexural strength (Rice 1987:362).

\section{FIRING CONDITIONS}

The Caddo potters at the Leaning Rock site fired most of their vessels in a reducing or low oxygen environment. possibly smothered in a bed of coals from a wood fire. Many of these vessels - particularly the decorated vessels-were subsequently cooled in a high oxygen environment (Table 12), suggesting that the fire-hardened vessel was removed from the fire to cool. This allowed either one or both surfaces of the vessels to become oxidized, producing a lighter brown to reddish-brown vessel color with a dark gray to black core.

Table 12. Firing conditions of the ceramic sherds by ware.

\begin{tabular}{|lccc|}
\hline \multicolumn{1}{|c}{ Firing conditions } & Plain rim & Fine ware & Utility ware \\
\hline $\begin{array}{l}\text { Oxidized* } \\
\text { Incompletely }\end{array}$ & $4.2 * *$ & 23.3 & 16.7 \\
$\begin{array}{l}\text { Oxidized } \\
\text { Reduced }\end{array}$ & 20.9 & 13.3 & 13.6 \\
Reduced, cooled & 41.7 & 6.7 & 23.0 \\
in a high oxygen & & & \\
environment & 33.3 & 56.6 & 47.0 \\
\hline *see Teltser (1993) & & & \\
** percentage & & \\
\hline
\end{tabular}

The differences in firing conditions apparent in the Table 12 data for ceramic vessel sherds indicate that the Leaning Rock fine wares and utility wares were fired differently by Caddo potters than the plain wares. Nevertheless, fring conditions are relatively heterogeneous among all three ceramic wares, suggesting that these vessel wares were used for multiple purposes (and had multiple forms) - cooking pots, containers, and serving vessels, to mention the most common vessel forms--since the diversity in firing is matched by the diversity in forms, temper, and pastes. It is clear that the primarily grog-tempered ceramic wares at Leaning Rock were fired in such a way that they were quite serviceable and durable, and fired for as long a time that the vessels were not subject to diminished strength from cumulative thermal fatigue, cracks, or fractures. 


\section{PIPE SHERDS}

There is a single pipe bowl sherd from the Leaning Rock site (Unit 13,10-20 cm bs). It is probably from an elbow pipe. The pipe is bone-tempered, and the bowl had been lightly brushed before the pipe was fired, and there is a grid of incised lines overlying the brushing background (Figure 31 ).

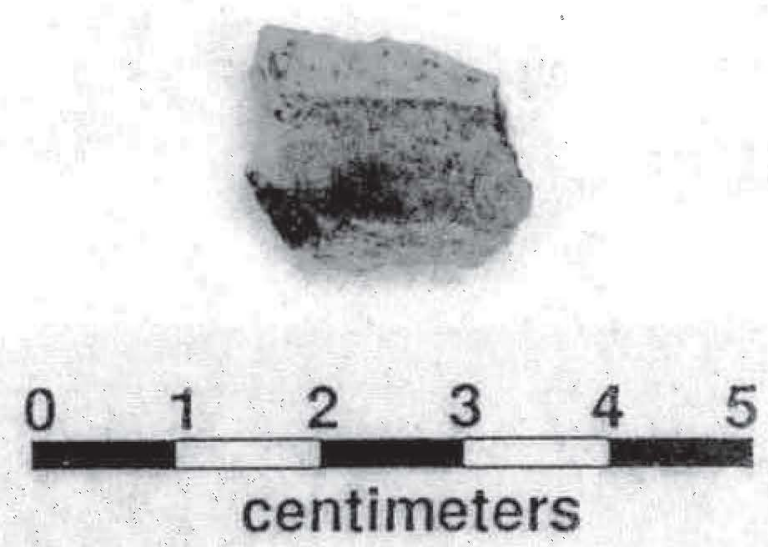

Figure 31. Leaning Rock site pipe bowl sherd.

\section{MODIFIED SHERDS}

\section{Mark Walters and Timothy K. Perttula}

Six sherds have drilled perforations in them (Figure 32a-b). The sherds are thick body or base sherds from broken vessels. These drilled sherds are considered to be broken or incomplete spindle whorls used by Caddo weavers in the making of textile fabrics. Actually, the drilled base sherd is the whorl that was placed on a wooden spindle to add weight to maintain the spinning motion, and to prevent the fiber from falling off of the rod as it was being spun. The spindle is rotated while the fibers were pulled from the rod with one's fingers, spinning yarn. This method of spinning goes back thousands of years until it was replaced by the spinning wheel in the 16th century. Through history whorls were made of many substances: wood, stone, bone, metal, and pottery. In Southern Peru, Walters excavated tombs of females with the surviving wooden spindle, a ball of yarn, and polished stone whorls. The weavers at Leaning Rock recycled a base from a broken pot as was common all across North America. Unfortunately, preservation in East Texas is not equal to that in Peru, and thus we have no indication concerning what fibers the weavers at Leaning Rock were using.

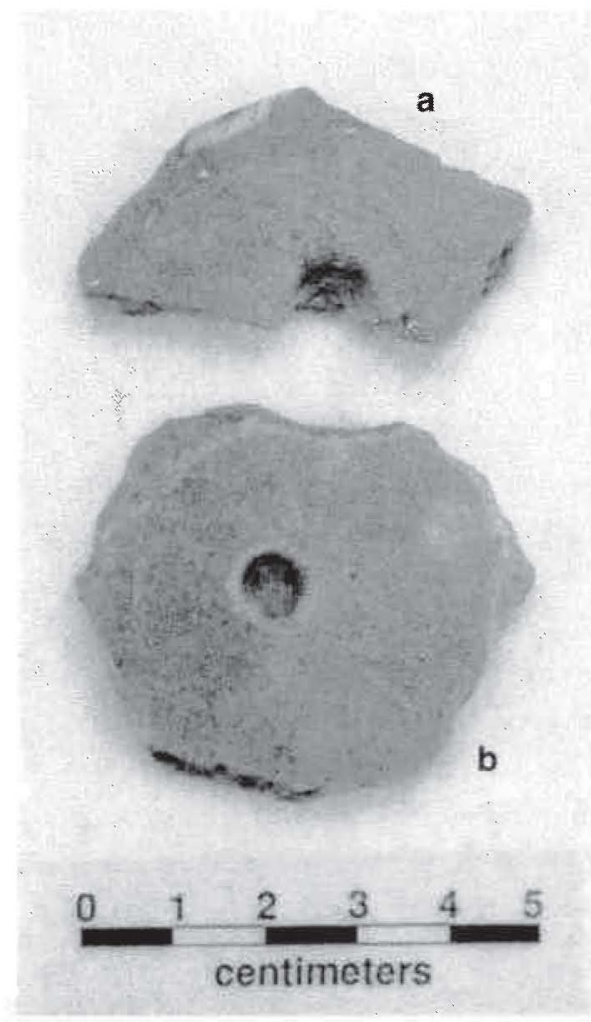

Figure 32. Modified sherds. Provenience: $a$, Unit 12. Iv. 2 ; b, Unit 11, 1v. 3. 
The one complete drilled base sherd or spindle whorl is from Unit $11,40-50 \mathrm{~cm}$ bs. The diameter of the drilled hole was $12 \mathrm{~mm}$ and the hole was beveled on the upper and lower surfaces. The three broken spindle whorls have 7-10.0 mm diameter perforations; the modified sherds are broken along the perforation. Two other base sherds have incomplete perforations begun on either the interior or exterior surfaces of the sherds. Perforation diameters ranged from $7.4-10.8 \mathrm{~mm}$.

\section{PLAIN BODY SHERDS AND BASES FROM LEANING ROCK}

\section{Plain Body Sherds}

In addition to the decorated sherds from the Leaning Rock site (see above), and the 130 plain rims, there were 2334 plain body sherds from the site. A total of 343 were collected from the surface, and 303 of these were from a controlled surface collection prior to excavations (Figure 33). The highest densities of plain sherds occur in the southern and western part of the surface collection grid, as well as in the southwestern part of the landform. Sherd densities in the surface collection ranged from $0-16$ sherds per $5 \times 5 \mathrm{~m}$ collection unit. The sherds are distributed over a 35 (north-south) $45 \mathrm{~m}$ (east-west) area, with three smaller concentrations of sherds that may correlate to areas of possible midden deposits (see Figures 1 and 33). The remaining 1991 plain body sherds from Leaning Rock were from the excavations, and they occur at a density of 66 sherds per $\mathrm{m}^{3}$ of excavated archeological deposits.

All plain body sherds are included in one category, although they were obviously from different vessel forms as well as vessels with different functions. The thicker sherds are inferred to be from utility vessels because "in general larger vessels require thicker walls for structural support" (Rice 1987:227). The overall average thickness of the plain body sherds was $7.5 \mathrm{~mm}$.

As noted in the description of the decorated sherds and plain rims, there was a notable percentage of plain vessels at Leaning Rock. Also portions of decorated vessels, especially those that were only decorated on the rim area rather than the body, would have been plain. It would be impossible to determine if an individual plain sherd came from a decorated or plain vessel.

Overall, the plain body sherds are primarily from vessels tempered with grog (Table 13). Thirty-two percent had bone temper, and $33 \%$ had pieces of hematite or crushed sandstone added to the clay paste.

Firing conditions of the plain body sherds as observed in sherd cross-section revealed $17 \%$ were from vessels that were fired in an oxidizing environment. Another $5.8 \%$ were incompletely oxidized, $24 \%$ were from vessels fired and cooled in a reducing atmosphere, while $53 \%$ were fired in a reducing atmosphere but cooled in the open air.

One obvious observation of the plain sherds from Leaning Rock was their excellent preservation. In addition to their overall large size, they had well preserved surfaces and sharp breaks. This may be the result of increased organics from the midden matrix that made the soil less acidic and thus limited sherd surface degradation. As previously mentioned, soil tests revealed that $\mathrm{pH}$ levels in the midden area were 6.47 (slightly acid) compared to levels of 5.56 (medium acid) outside the midden area.

The sherds retained the evidence of various surface treatments, techniques that were used in the finishing process of pottery construction. Approximately $62 \%$ of the plain body sherds were burnished on both interior and exterior surfaces; $35 \%$ had burnished exterior surfaces and smoothed interior surfaces; and $1.5 \%$ had 


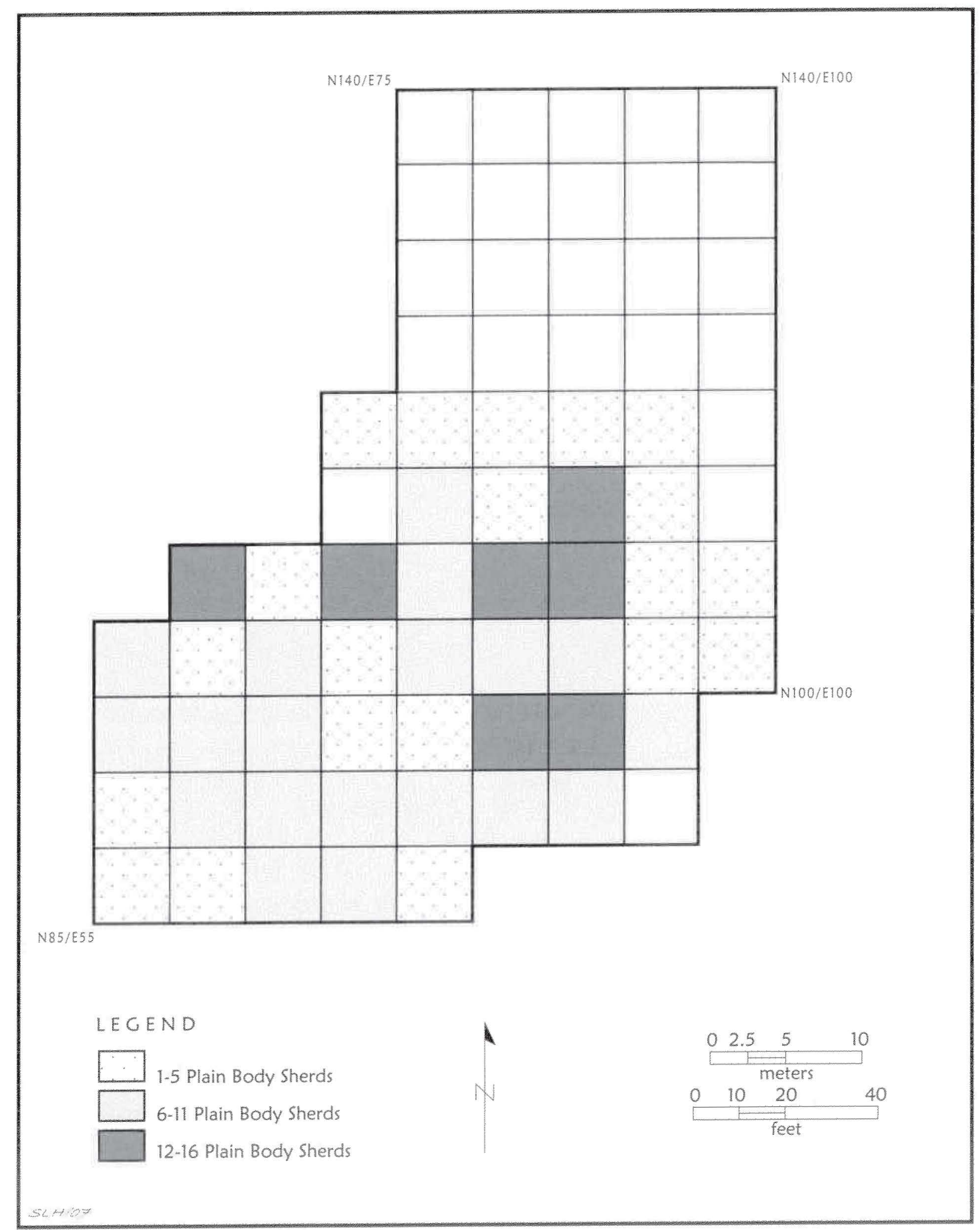

Figure 33. Distribution of plain body and base sherds in the Leaning Rock site surface collection. 
Tabe 13. Proportions of tempered sherds among the plain body awd base sherds.

\begin{tabular}{|c|c|}
\hline Temper & Parcentage \\
\hline Grog & $50 \%$ \\
\hline Grog-bone & 17 \\
\hline Grog-bone-hematite" & 15 \\
\hline Grog-hematite & 13 \\
\hline Hematite & 5 \\
\hline $\begin{array}{l}\text { * Crushed ferruginou } \\
\text { hematite }\end{array}$ & Ustone cemented by \\
\hline
\end{tabular}
purposes, or a combination of both, the end result was a ceramic vessel that showed a great deal of timeconsuming dedication.

Durability or serviceability would have been important properties of the pottery produced by the potters at Leaning Rock. Hardness (Table 14 ) is one aspect that would have infuenced how long a vessel would have been serviceable.

Ten sherds were selected from the Leaning Rock plain body sherd collection and compared with equal numbers of plain body sherds from the nearby Redwine (4ISM193) and Bryan Hardy (4ISM55) sites using the Mohs' mineral hardness scale (Table 15). This hardness test was conducted by geologist Berne Ward, a long-time TAS member.

Results from non-kin-fired pottery commonly ranges between 3 and 5 in hardness. Results from the Mohs" hardness test on a sample of sherds from Leaning Rock, Redwine, and Bryan Hardy indicate a hardness range from 2.5104 .5 .

The hardness of a given clay generally increases with the temperature of Gring: all things being equal (Rice 1987:354). $800-900$ degrees $C$ is the range at which much of non-kin-fred

interior bumishing and exterior smoothing. A small percentage, $1.1 \%$, had exterior surfaces that were polished with bumished interiors. In his discussion oflihes from Leaning Rock, Shater (2007) describes several polishing stones that were probably used in the surface treatment stage of pottery production to produce a bumished surface. A bumished surface is characterized by "namow parallel linear facets" on the surface that by "compaction and reoricntation of the fine clay particles (through plastic how) grves a surface luster" (Rice 1987:138). At Leaning Rock the potters rubbed the ceramic vessel surface back and forth with a hard object, such as the pebbles recovered from excavations, in a horizontal direction that followed the colls making up the vessel wall. Whether this technique was for functional or stylistic
a ceramic vessel that showed a great deal of time-

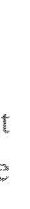

\section{.}


Table 15. Hardness Comparisons from Leaning Rock, Redwine, and Bryan Hardy sites.

\begin{tabular}{|c|c|c|c|c|c|}
\hline Site & $\begin{array}{l}\text { Exterior } \\
\text { Hardness }\end{array}$ & $\begin{array}{l}\text { Interior } \\
\text { Hardness }\end{array}$ & Temper & Firing* & $\begin{array}{l}\text { Surface } \\
\text { Treatment } \\
\text { (Int./Ext.) }\end{array}$ \\
\hline \multicolumn{6}{|c|}{ Leaning Rock } \\
\hline 1 & 2.5 & 3.0 & $\mathrm{~B} / \mathrm{G}^{* *}$ & $\mathrm{H}$ & $2 / 5 * * *$ \\
\hline 2 & 2.5 & 3.0 & G & B & $2 / 5$ \\
\hline 3 & 3.5 & 3.5 & G/Hem & B & $2 / 5$ \\
\hline 4 & 3.0 & 3.5 & $\mathrm{G}$ & G & $2 / 5$ \\
\hline 5 & 3.5 & 3.5 & $G$ & $\mathrm{~B}$ & $2 / 5$ \\
\hline 6 & 2.5 & 3.0 & $\mathrm{G} / \mathrm{B}$ & $\mathrm{A}$ & $2 / 5$ \\
\hline 7 & 3.5 & 3.5 & $\mathrm{G} / \mathrm{B}$ & G & $2 / 5$ \\
\hline 8 & 3.5 & 3.5 & $\mathrm{G} / \mathrm{Hem}$ & $\mathrm{C}$ & $2 / 5$ \\
\hline 9 & 3.0 & 3.5 & $\mathrm{G} / \mathrm{Hem}$ & $\mathrm{A}$ & $2 / 5$ \\
\hline 10 & 3.5 & 3.5 & G & A & $2 / 5$ \\
\hline \multicolumn{6}{|c|}{ Redwine } \\
\hline 1 & 3.5 & 3.5 & $\mathrm{G}$ & $\mathrm{G}$ & $1 / 4$ \\
\hline 2 & 3.5 & 3.5 & G & B & $2 / 5$ \\
\hline 3 & 3.5 & 3.5 & G & B & $2 / 5$ \\
\hline 4 & 3.0 & 3.5 & G/Hem & D & $2 / 5$ \\
\hline 5 & 3.5 & 3.5 & $\mathrm{~B} / \mathrm{G} / \mathrm{Hem}$ & B & $2 / 5$ \\
\hline 6 & 2.5 & 2.5 & $\mathrm{~B} / \mathrm{G}$ & A & $2 / 5$ \\
\hline 7 & 3.5 & 3.5 & $\mathrm{G} / \mathrm{Hem}$ & $F$ & $2 / 5$ \\
\hline 8 & 3.5 & 3.5 & $\mathrm{G} / \mathrm{Hem}$ & $\mathrm{E}$ & $2 / 5$ \\
\hline 9 & 3.5 & 4.0 & $\mathrm{G} / \mathrm{Hem}$ & $B$ & $2 / 5$ \\
\hline 10 & 3.5 & 3.5 & G & G & $2 / 5$ \\
\hline \multicolumn{6}{|c|}{ Bryan Hardy } \\
\hline 1 & 3.5 & 3.5 & G & B & $2 / 5$ \\
\hline 2 & 2.5 & 3.0 & $\mathrm{G}$ & G & $2 / 5$ \\
\hline 3 & 3.0 & 3.5 & $\mathrm{G}$ & $\mathrm{G}$ & $2 / 5$ \\
\hline 4 & 3.0 & 4.5 & $\mathrm{G}$ & A & $2 / 5$ \\
\hline 5 & 3.5 & 4.5 & $\mathrm{G}$ & G & $2 / 5$ \\
\hline 6 & 4.5 & 4.5 & $\mathrm{G}$ & $B$ & $2 / 5$ \\
\hline 7 & 3.0 & 3.5 & $\mathrm{G} / \mathrm{B}$ & $\mathrm{D}$ & $2 / 5$ \\
\hline 8 & 2.5 & 3.0 & $\mathrm{G}$ & D & $2 / 5$ \\
\hline 9 & 2.0 & 2.5 & $\mathrm{G}$ & $\mathrm{C}$ & $2 / 5$ \\
\hline 10 & 3.5 & 3.5 & $\mathrm{G} / \mathrm{B}$ & $\mathrm{E}$ & $2 / 5$ \\
\hline $\begin{array}{l}* \text { Firir } \\
* * \mathrm{G}=\mathrm{s} \\
* * 2 / 4\end{array}$ & $\begin{array}{l}\text { follow Telts } \\
\text {; Hem=hem } \\
\text { crior burnis }\end{array}$ & 3: Figure 2) & oothed & & \\
\hline
\end{tabular}


prehistoric pottery was fired. Taking an average of exterior and interior hardness scores, the Redwine pottery has the highest average of 3.4 with Bryan Hardy next with 3.35, and Leaning Rock last with an average hardness of 3.23. By comparison, the ceramic sherds from the Smithport Landing site - an Early to Middle Caddo settlement in De Soto Parish, Louisiana-has hardness values ranging only from 2 to 3 (Webb 1963:151).

Hardness can also be affected by the firing atmosphere. A low oxygen or reduced atmosphere firing will result in a harder pottery. Over $50 \%$ of the scores over 3.5 in hardness came from vessels that had been fired in a reduced atmosphere. Only $16 \%$ of incompletely fired and $10 \%$ of oxidized sherds rated 3.5 hardness or higher. One interesting note is the fact that in several instances interior hardness scores are higher than the exterior scores. In fact, there is no instance where exterior scores are higher than interior scores.

A comparison of plain body sherds from Leaning Rock with similar sherds from Redwine and Bryan Hardy sites indicates that they shared similar technologies in the production of non-kiln-fired pottery, at least to the extent of maximum hardness of ceramic vessels. The Mohs' hardness test could be used as a formal test in comparing other Caddo pottery assemblages in the region that represent different time and space contexts.

\section{PLAIN BASES}

There were also 26 base sherds, one from the controlled surface collection and the rest from excavations. Thickness ranged from $9.2 \mathrm{~mm}$ to $16.7 \mathrm{~mm}$ with $12.9 \mathrm{~mm}$ being the average base sherd thickness. The bases were all flat, which is the most stable form but "may not be the most efficient for cooking because of thermal differentials" (Rice 1987:241-242).

\section{Function based on an examination of the plain body and base sherds}

Most of the vessels represented by the plain body sherd collection at Leaning Rock were simple bowls, carinated bowls, and jars. There were few examples of the "water bottle" form that is commonly present on many Caddo sites. While it is hard to reconstruct the function of vessels from plain sherds, Rye (1981:27) states "cook pots do not usually have sharp angles," such as carinated bowls, "which would cause uneven heating and thermal stress over the fire." At Leaning Rock, sherds with exterior sooting and heavy interior cooking residue (such as one specimen that was submitted for phytolith and starch analysis, see Linda Scott Cummings, this article) came from jar forms. Perhaps the carinated bowl form was reserved for serving and/or storage.

\section{INSTRUMENTAL NEUTRON ACTIVATION ANALYSIS}

\section{Timothy K. Pertula}

Twenty ceramic sherds (three from fine wares and 17 utility ware sherds) and two clay samples have been submitted for instrumental neutron activation analysis (INAA) from the Leaning Rock site to the Missouri University Research Reactor (MURR). Our research interests in the INAA of Leaning Rock Caddo sherds and clay samples center on determining the likely compositional origin and manufacturing locale of the utility ware and fine ware vessels from this domestic Caddo settlement. Being situated in the middle Sabine River basin, were these vessels made using Smith or Rusk chemical group clays (Descantes et al. 2003; Perttula 2002), or were other clay sources (such as the Titus chemical group) within the region important to the Leaning Rock Caddo potters? 
We particularly wished to establish the compositional nature of locally made ceramic wares at the site and possibly pinpoint their manufacturing locales within this part of the middle Sabine River basin. There is a possibility that a certain percent of the ceramic vessels at the site were obtained by trade and exchange with contemporaneous Caddo groups, and the INAA of the Leaning Rock sherds (especially the engraved fine wares, which are more commonly traded and exchanged) ought to help establish, to some extent, the presence and direction of the trade of non-locally produced Caddo vessels. These determinations will be facilitated by comparisons with the 10 existing Caddo ceramic compositional groups in the MURR database.

As the following contribution by Ferguson and Glascock indicates, $60 \%$ of the submitted sherd INAA samples from the Leaning Rock site are from vessels made with Titus chemical group clays, and another $15 \%$ are probably made from these clays; the other $25 \%$ of the sherds are not currently assigned to a chemical group. Titus chemical group clays in ceramic vessel sherds are found most commonly on Caddo sites between the Sulphur River on the north and the Sabine River on the south (Perttula 2002:Figure 5.2), including sites such as Leaning Rock situated on streams that drain north into the Sabine River, such as Jackson Creek.

The analyzed vessel sherds (tempered with grog, bone-hematite, bone-grog, and grog-hematite) from definite Titus chemical group clays at the Leaning Rock site include those with the following decorations: parallel brushed-tool punctated $(n=1)$; curvilinear incised zone filled with tool punctates $(n=1)$; fingernail punctated rows $(n=1)$; tool punctated rows $(n=1)$; hatched pendant triangles on an engraved bottle $(n=1)$; cross-hatched engraved panel $(n=1)$; cross-hatched incised $(n=3)$; and diagonal incised $(n=1)$. Both plain rims in the sample are included in the Titus chemical group.

Those sherds from vessels probably made of Titus chemical group clays include two decorated with parallel brushed marks and one with diagonal incised lines $(n=1)$ on the rim of an utility ware jar. The five sherds from unidentified chemical group clays comprise one body sherd with a triangular incised zone filled with tool punctates; another with a cross-hatched engraved panel; a diagonal brushed rim and a body sherd with overlapping brushed marks; and a body sherd with cross-hatched incised lines above a set of horizontal incised lines.

It is worth noting that none of the four brushed sherds in the INAA sample from the Leaning Rock can be definitively assigned to the Titus chemical group, which apparently represents a local clay source used by the Caddo potters that lived at the Leaning Rock site. This suggests several possibilities, the first being that the Leaning Rock Caddo potters used a different clay (one still unidentified chemically) to manufacture their brushed cooking jars. Another possibility is that the brushed utility ware jars found at the Leaning Rock site-which comprise approximately $17 \%$ of the decorated sherds-may not have been made by Leaning Rock potters but other as yet unknown Caddo potters from another community, but ended up at the site through local trade and exchange activities.

\title{
INSTRUMENTAL NEUTRON ACTIVATION ANALYSIS OF CADDO POTTERY AND CLAY SAMPLES FROM THE LEANING ROCK SITE (41SM325)
}

\author{
Jeffrey R. Ferguson, Lesite G. Cecil, and Michael D. Glascock
}

\section{INTRODUCTION}

Pottery $(n=20)$ and clay samples ( $n=2)$ from the Leaning Rock site ( 4 ISM325) were analyzed by instrumental neutron activation analysis (INAA) at the University of Missouri Research Reactor Center (MURR). Here, 
we describe sample preparation and analytical techniques used at MURR and report the compositional group membership of the new samples. The Caddo database consists of approximately 900 samples and 10 reference groups. We are currently in the process of reassessing all of the Caddo samples to create more inclusive reference groups, but for the purpose of assigning these samples, the tightly defined reference groups presented in Ferguson and Glascock (2006) are used.

\section{SAMPLE PREPARATION}

Pottery samples were prepared for INAA using procedures standard at MURR. Fragments of about $1 \mathrm{~cm}^{2}$ were removed from each sample and abraded using a silicon carbide burr in order to remove glaze, slip, paint, and any adhering soil, thereby reducing the risk of measuring contamination. The samples were washed in deionized water and allowed to dry in the laboratory. Once dry, the individual sherds were ground to powder in an agate mortar to homogenize the samples. Archival samples were retained from each sherd (when possible) for future research.

Two analytical samples were prepared from each source specimen. Portions of approximately $150 \mathrm{mg}$ of powder were weighed into clean high-density polyethylene vials used for short irradiations at MURR. At the same time, $200 \mathrm{mg}$ of each sample was weighed into clean high-purity quartz vials used for long irradiations. Individual sample weights were recorded to the nearest $0.01 \mathrm{mg}$ using an analytical balance. Both vials were sealed prior to irradiation. Along with the unknown samples, standards made from National Institute of Standards and Technology (NIST) certified standard reference materials of SRM-1633a (coal fly ash) and SRM-688 (basalt rock) were similarly prepared, as were quality control samples (e.g., standards treated as unknowns) of SRM-278 (obsidian rock) and Ohio Red Clay (a standard developed for in-house applications).

\section{IRRADIATION AND GAMMA-RAY SPECTROSCOPY}

Neutron activation analysis of ceramics at MURR, which consists of two irradiations and a total of three gamma counts, constitutes a superset of the procedures used at most other INAA laboratories (Glascock 1992; Neff 1992, 2000). As discussed in detail by Glascock (1992), a short irradiation is carried out through the pneumatic tube irradiation system. Samples in the polyvials are sequentially irradiated, two at a time, for five seconds by a neutron flux of $8 \times 10^{13} \mathrm{n} \mathrm{cm}^{-2} \mathrm{~s}^{-1}$. The 720 -second count yields gamma spectra containing peaks for nine short-lived elements aluminum ( $\mathrm{Al}$ ), barium (Ba), calcium ( $\mathrm{Ca}$ ), dysprosium (Dy), potassium $(\mathrm{K})$, manganese $(\mathrm{Mn})$, sodium (Na), titanium (Ti), and vanadium (V). The samples are encapsulated in quartz vials and are subjected to a 24 hour irradiation at a neutron flux of $5 \times 10^{13} \mathrm{n} \mathrm{cm}^{-2} \mathrm{~s}^{-1}$. This long irradiation is analogous to the single irradiation utilized at most other laboratories. After the long irradiation, samples decay for seven days, and then are counted for 1,800 seconds (the "middle count") on a high-resolution germanium detector coupled to an automatic sample changer. The middle count yields determinations of seven medium half-life elements, namely arsenic (As), lanthanum (La), lutetium (Lu), neodymium (Nd), samarium $(\mathrm{Sm})$, uranium (U), and ytterbium (Yb). After an additional three- or four-week decay, a final count of 8,500 seconds is carried out on each sample. The latter measurement yields the following 17 long half-life elements: cerium (Ce), cobalt (Co), chromium (Cr), cesium (Cs), europium (Eu), iron (Fe), hafnium (Hf), nickel (Ni), rubidium ( $\mathrm{Rb}$ ), antimony ( $\mathrm{Sb})$, scandium ( $\mathrm{Sc})$, strontium ( $\mathrm{Sr}$ ), tantalum (Ta), terbium (Tb), thorium (Th), zine $(\mathrm{Zn})$, and zirconium ( $\mathrm{Zr})$.

The element concentration data from the three measurements are tabulated in parts per million ( $\mathrm{ppm}$ ) using the EXCEL spreadsheet program. Descriptive data for the archeological samples were appended to the 
concentration spreadsheet. The data are also stored in a dBASE/FOXPRO database file useful for organizing, sorting, and extracting sample information.

\section{INTERPRETING CHEMICAL DATA}

The analyses at MURR described previously produced elemental concentration values for 33 elements in most of the analyzed samples. Data for $\mathrm{Ni}$ in most samples was below detection limits (as is the norm for most New World ceramic analyses) and was removed from consideration during the statistical analysis. Calcium levels were found to be high enough in approximately one-third of the specimens to require a calcium correction of the dataset. Because calcium has the potential to affect (dilute) the concentrations of other elements in the analysis, all samples were mathematically corrected to compensate for any possible calcium-included effects (the data were examined before and after calcium correction and the results were similar). The following mathematical correction was used as it has been proven to be effective in other calcium-rich datasets (Cogswell et al. 1998:64; Steponaitis et al. 1996):

$$
e^{\prime}=\frac{10^{6} e}{10^{6}-2.5 c}
$$

where $e$ is the corrected concentration of a given element in ppm, $e$ is the measured concentration of that element in ppm, and $c$ is the concentration of elemental calcium in ppm. After the calcium correction, statistical analysis was subsequently carried out on base-10 logarithms of concentrations on the remaining 31 elements. Use of log concentrations rather than raw data compensates for differences in magnitude between the major elements, such as calcium, on one hand, and trace elements, such as the rare earth or lanthanide elements (REEs). Transformation to base 10 logarithms also yields a more normal distribution for many trace elements.

The interpretation of compositional data obtained from the analysis of archeological materials is discussed in detail elsewhere (e.g., Baxter and Buck 2000; Bieber et al. 1976; Bishop and Neff 1989; Glascock 1992; Harbottle 1976; Neff 2000) and will only be summarized here. The main goal of data analysis is to identify distinct homogeneous groups within the analytical database. Based on the provenance postulate of Weigand et al. (1977), different chemical groups may be assumed to represent geographically restricted sources. For lithic materials such as obsidian, basalt, and cryptocrystalline silicates (e.g, chert, flint, or jasper), raw material samples are frequently collected from known outcrops or secondary deposits and the compositional data obtained on the samples are used to define the source localities or boundaries. The locations of sources can also be inferred by comparing unknown specimens (i.e., ceramic artifacts) to known specimens (i.e., clay samples), by indirect methods such as the "criterion of abundance" (Bishop et al. 1992), or by arguments based on geological and sedimentological characteristics (e.g., Steponaitis et al. 1996). The ubiquity of ceramic raw materials usually makes it impossible to sample all potential "sources" intensively enough to create groups of knowns to which unknowns can be compared. Lithic sources tend to be more localized and compositionally homogeneous in the case of obsidian or compositionally heterogeneous as is the case for most cherts.

Compositional groups can be viewed as "centers of mass" in the compositional hyperspace described by the measured elemental data. Groups are characterized by the locations of their centroids and the unique relationships (i.e.. correlations) between the elements. Decisions about whether to assign a specimen to a particular compositional group are based on the overall probability that the measured concentrations for the specimen could have been obtained from that group.

Initial hypotheses about source-related subgroups in the compositional data can be derived from non-compositional information (e.g. archeological context, decorative attributes, etc.) or from application of various 
pattern-recognition techniques to the multivariate chemical data. Some of the pattern recognition techniques that have been used to investigate archeological data sets are cluster analysis (CA), principal components analysis (PCA), and discriminant analysis (DA). Each of the techniques has it own advantages and disadvantages that may depend upon the types and quantity of data available for interpretation.

The variables (measured elements) in archeological and geological data sets are often correlated and frequently large in number. This makes handling and interpreting patterns within the data difficult. Therefore, it is often useful to transform the original variables into a smaller set of uncorrelated variables in order to make data interpretation easier. Of the above-mentioned pattern recognition techniques, PCA is a technique that transforms the data from the original correlated variables into uncorrelated variables most easily.

PCA creates a new set of reference axes arranged in a decreasing order of the variance subsumed. The individual PCs are linear combinations of the original variables. The data can be displayed on combinations of the new axes, just as they can be displayed on the original elemental concentration axes. PCA can be used in a pure pattern-recognition mode (i.e., to search for subgroups in an undifferentiated data set), or in a more evaluative mode (i.e., to assess the coherence of hypothetical groups suggested by other criteria). Generally, compositional differences between specimens can be expected to be larger for specimens in different groups than for specimens in the same group, and this implies that groups should be detectable as distinct areas of high point density on plots of the first few components.

It is well known that PCA of chemical data is scale dependent (Mardia et al. 1979), and analyses tend to be dominated by those elements or isotopes for which the concentrations are relatively large. As a result, standardization methods are common to most statistical packages. A common approach is to transform the data into logarithms (e.g., base-10). As an initial step in the PCA of most chemical data at MURR, the data are transformed into log concentrations to equalize the differences in variance between the major elements such as $\mathrm{Al}, \mathrm{Ca}$, and $\mathrm{Fe}$, on one hand and trace elements, such as the rare-earth elements, on the other hand. An additional advantage of the transformation is that it appears to produce more nearly normal distributions for the trace elements.

One frequently exploited strength of PCA, discussed by Baxter (1992), Baxter and Buck (2000), and Neff (1994, 2002), is that it can be applied as a simultaneous R-and Q-mode technique, with both variables (elements) and objects (individual analyzed samples) displayed on the same set of principal component reference axes. A plot using the first two principal components as axes is usually the best possible two-dimensional representation of the correlation or variance-covariance structure within the data set. Small angles between the vectors from the origin to variable coordinates indicate strong positive correlation; angles at 90 degrees indicate no correlation; and angles close to 180 degrees indicate strong negative correlation. Likewise, a plot of sample coordinates on these same axes will be the best two-dimensional representation of Euclidean relations among the samples in log-concentration space (if the PCA was based on the variance-covariance matrix) or standardized logconcentration space (if the PCA was based on the correlation matrix). Displaying both objects and variables on the same plot makes it possible to observe the contributions of specific elements to group separation and to the distinctive shapes of the various groups. Such a plot is commonly referred to as a "biplot" in reference to the simultaneous plotting of objects and variables. The variable inter-relationships inferred from a biplot can be verified directly by inspecting bivariate elemental concentration plots (note that a bivariate plot of elemental concentrations is not a biplot).

Whether a group can be discriminated easily from other groups can be evaluated visually in two dimensions or statistically in multiple dimensions. A metric known as the Mahalanobis distance (or generalized distance) makes it possible to describe the separation between groups or between individual samples and groups on multiple 
dimensions. The Mahalanobis distance of a specimen from a group centroid (Bieber et al. 1976; Bishop and Neff 1989 ) is defined by:

$$
D_{x}^{2}=[y-\bar{X}]^{T} L[y-\bar{X}]
$$

where $y$ is the $1 \times \mathrm{m}$ array of logged elemental concentrations for the specimen of interest $X$ is the $\mathrm{n} x \mathrm{~m}$ data matrix of logged concentrations for the group to which the point is being compared with $X^{-}$being its $1 \mathrm{x} \mathrm{m}$ centroid, and $I_{v}$ is the inverse of the $m x$ variance-covariance matrix of group $X$. Because Mahalanobis distance takes into account variances and covariances in the multivariate group, it is analogous to expressing distance from a univariate mean in standard deviation units. Like standard deviation units, Mahalanobis distances can be converted into probabilities of group membership for individual specimens. For relatively small sample sizes, it is appropriate to base probabilities on Hotelling's $T^{2}$, which is the multivariate extension of the univariate Student's $t$.

When group sizes are small, Mahalanobis distance-based probabilities can fluctuate dramatically depending upon whether or not each specimen is assumed to be a member of the group to which it is being compared. Harbottle (1976) calls this phenomenon "stretchability" in reference to the tendency of an included specimen to stretch the group in the direction of its own location in elemental concentration space. This problem can be circumvented by cross-validation, that is, by removing each specimen from its presumed group before calculating its own probability of membership (Baxter 1994; Leese and Main 1994). This is a conservative approach to group evaluation that may sometimes exclude true group members.

Small sample and group sizes place further constraints on the use of Mahalanobis distance: with more elements than samples, the group variance-covariance matrix is singular, thus rendering calculation of $I_{x}$ (and $D^{2}$ itself) impossible. Therefore, the dimensionality of the groups must somehow be reduced. One approach would be to eliminate elements considered irrelevant or redundant. The problem with this approach is that the investigator's preconceptions about which elements should be discriminate may not be valid. It also squanders the main advantage of multi-element analysis, namely the capability to measure a large number of elements. An alternative approach is to calculate Mahalanobis distances with the scores on principal components extracted from the variance-covariance or correlation matrix for the complete data set. This approach entails only the assumption, entirely reasonable in light of the above discussion of PCA, that most group-separating differences should be visible on the first several PCs. Unless a data set is extremely complex, containing numerous distinct groups, using enough components to subsume at least $90 \%$ of the total variance in the data can be generally assumed to yield Mahalanobis distances that approximate Mahalanobis distances in full elemental concentration space.

Lastly, Mahalanobis distance calculations are also quite useful for handling missing data (Sayre 1975). When many specimens are analyzed for a large number of elements, it is almost certain that a few element concentrations will be missed for some of the specimens. This occurs most frequently when the concentration for an element is near the detection limit. Rather than eliminate the specimen or the element from consideration, it is possible to substitute a missing value by replacing it with a value that minimizes the Mahalanobis distance for the specimen from the group centroid. Thus, those few specimens which are missing a single concentration value can still be used in group calculations.

\section{RESULTS AND CONCLUSIONS}

The primary questions addressed here are: (1) How do the new samples fit within the compositional group structure previously developed for the Caddoan archeological area? (2) Are the clay samples related to either 
the newly analyzed sherds or to the previously defined compositional groups? Table 16 displays the group assignments and some descriptive data for the samples.

Table 16. Chemical group assigments and descriptive data for pottery and clay samples.

\begin{tabular}{|c|c|c|}
\hline ANID & Chemical Group & Material \\
\hline TKP804 & Titus & Brushed-punctated utility ware \\
\hline TKP805 & Titus & Plain rim \\
\hline TKP806 & Titus & Plain rim \\
\hline TKP807 & Titus & Incised-punctated utility ware \\
\hline TKP808 & Unassigned & Incised-punctated utility ware \\
\hline TKPSOG & Titus & Fingernail punctated utility ware \\
\hline TKP810 & Titus & Tool punctated utility ware \\
\hline TKP811 & Titus & Fine ware engraved bottle sherd \\
\hline TKP812 & Titus & Engraved fine ware \\
\hline TKP813 & Unassigned & Engraved fine ware \\
\hline TKP814 & titus? & Parallel brushed utility ware \\
\hline TKP815 & titus? & Parallel brushed utility ware \\
\hline TKP816 & Unassigned & Overlapping brushed utility ware \\
\hline TKP817 & Unassigned & Diagonal brushed utility ware \\
\hline TKP818 & Titus & Cross-hatched incised utlity ware \\
\hline TKP819 & Titus & Diagonal incised utility ware \\
\hline TKP820 & titus'? & Diagonal incised utility ware \\
\hline TKP821 & Unassigned & Cross-hatched and horizontal incised utility ware \\
\hline TKP822 & Titus & Cross-hatched incised utility ware \\
\hline TKP823 & Titus & Cross-hatched incised utility ware \\
\hline TKP824 & Unassigned & Clay from the Leaning Rock site area \\
\hline TKP825 & Unassigned & Clay from the Leaning Rock site area \\
\hline
\end{tabular}

\section{COMPOSITIONAL GROUP STRUCTURE}

Before discussing the compositional group assignments of the new samples, it is necessary to discuss the current status of the reference groups. The similarity of the clay sources in the Caddoan archeological area results in large compositional groups with considerable overlap. In the most recent analysis of Caddo pottery (Ferguson and Glascock 2006) we refined the reference groups to allow for some separation of the groups using Mahalanobis distance calculations. Prior to this reanalysis, the reference groups had grown to the point that there was very little chemical separation. As an unfortunate result of this refinement, approximately half of the Caddo sherds in the database are now unassigned. The reference groups are now reduced to much tighter groups that allow more confident assignment of new samples; however, this results in many new samples not fitting well into existing reference groups. In the following paragraphs we explain why none of the new samples belong in any of the reference groups except for the Titus reference group, and we classify the Titus group sherds as either clearly assigned to the reterence group or likely (but not statistically verified) members.

The most chemically unique reference group is the Sandy Paste group; the Sandy Paste sherds were made in Woodland period times (i.e. before ca. A.D. 800) in parts of East Texas. This group has diluted concentrations of 
most elements, likely resulting from large amounts of sand (although we are not sure if this is due to the use of a sandy clay. or the addition of sand as a temper). None of the Leaning Rock samples plot well within this group.

The first group, Rusk, consists of 20 members, and thus precludes the use of Mahalanobis distance calculations (due to small sample size). Figure 34 plots the distribution of the new samples relative to the Rusk and Sandy Paste groups, according to concentrations of chromium and lutetium. Figure 35 plots the new samples relative to the very small ( $n=5$ ) Washington Square reference group. Figures 36 and 37 plot the Leaning Rock samples against the Hurricane $1(n=20)$ and Hurricane $2(n=25)$ reference groups, respectively. Figures 38 and 39 plot the samples against the Cypress $1(n=14)$ and Cypress $2(n=16)$ reference groups. The Cypress 1 reference group is a problematic group because is consistently overlaps with many other reference groups, particularly with the Titus reference group. The overlap of the Cypress 1 reference group with the Titus reference group is the likely reason why there are no plots that completely separate the new samples from the Cypress 1 reference group. This relationship may become clearer following the reanalysis of the entire Caddo database that is currently underway.

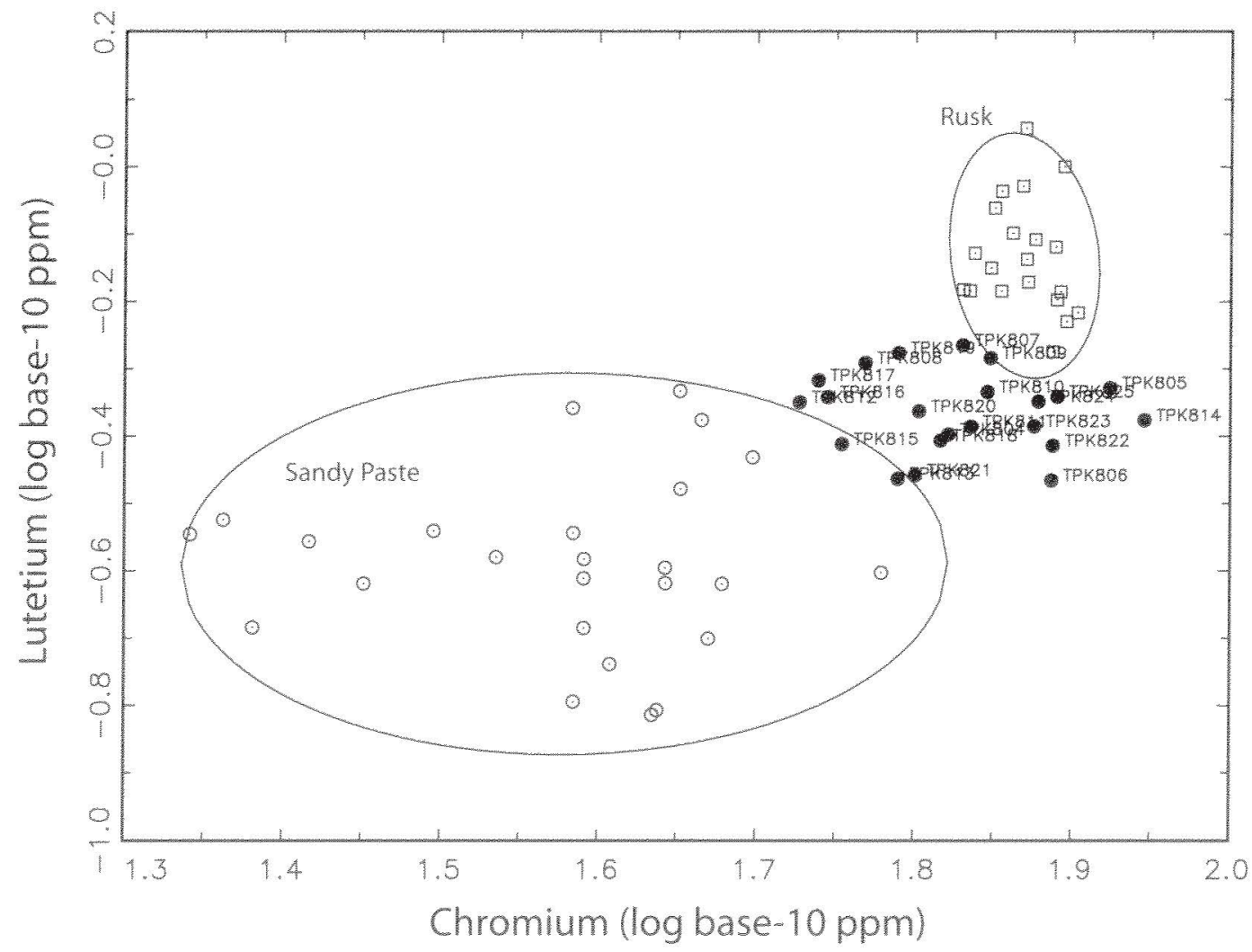

Figure 34. Bivariate plot of chromium and lutetium base-10 logged concentrations showing that the new samples do not match with either the Rusk or Sandy Paste Reference Groups. Ellipses represent a $90 \%$ confdence level for membershin in the group.

The three remaining reference groups, Titus, Smith, and Red River, are all large enough to permit statistical assessment of group membership using probabilities of group membership calculated from a Mahalanobis distance projection. Table 17 lists the probabilities of membership in each of the three groups for the new sherds from the Leaning Rock site assigned to the Titus reference group. Table 18 lists the probabilities of membership for each of the unassigned samples. Membership in the Titus reference group was accepted for sherds with at least 


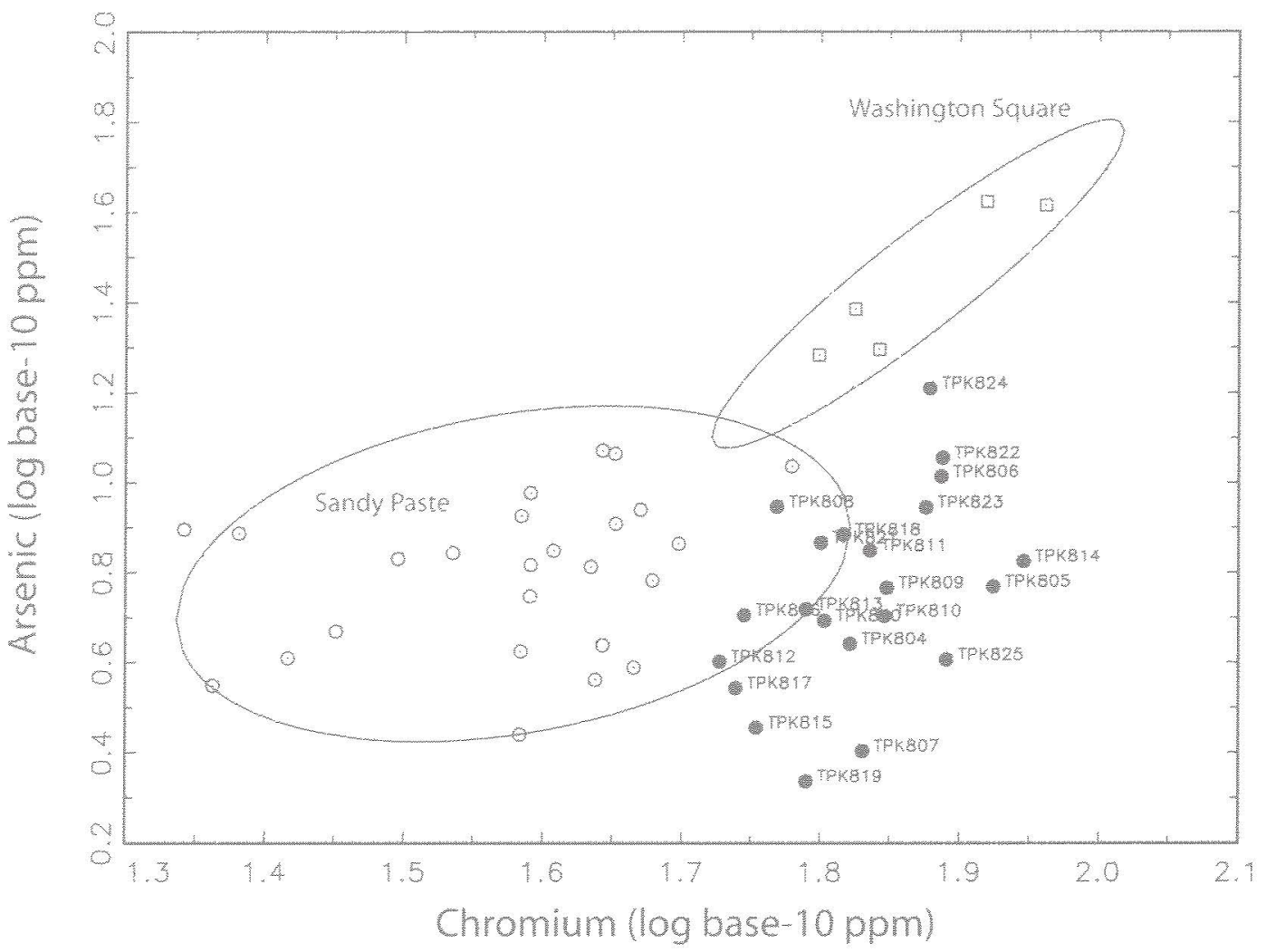

Figure 35. Bivariate plot of chromim and arsenic base-10 logged concentrations showing that the new samples do not natch with the Washington Square Reference Group. Elipses represent a $90 \%$ confidence lavel for membership in the group.

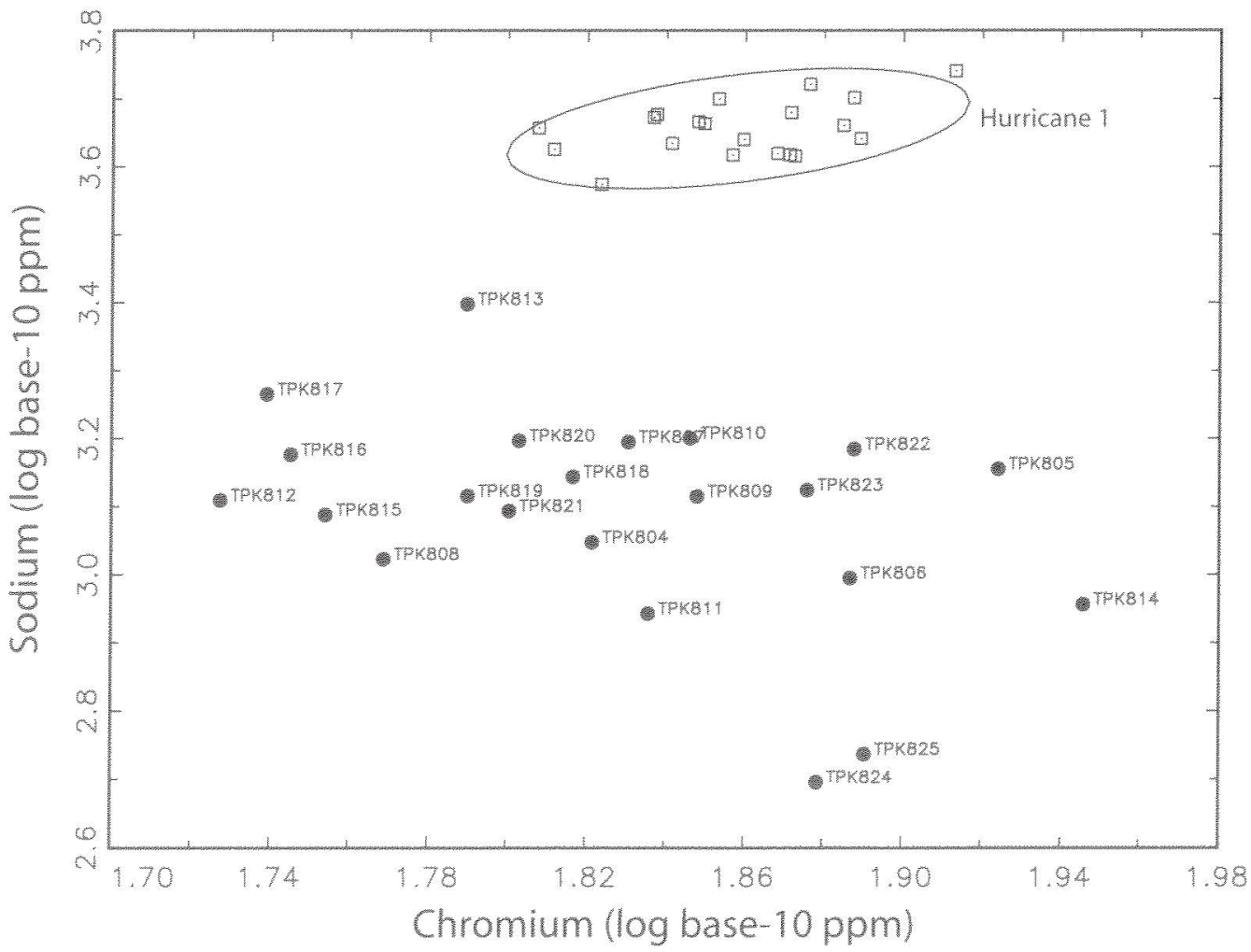

Figure 36 . Bivariate plot of sodum and chromim base-10 logged concentrations showing the separation from the Hurricane I Reference Group. Ellipses represent a $96 \%$ contence level for mambersin in the groum. 


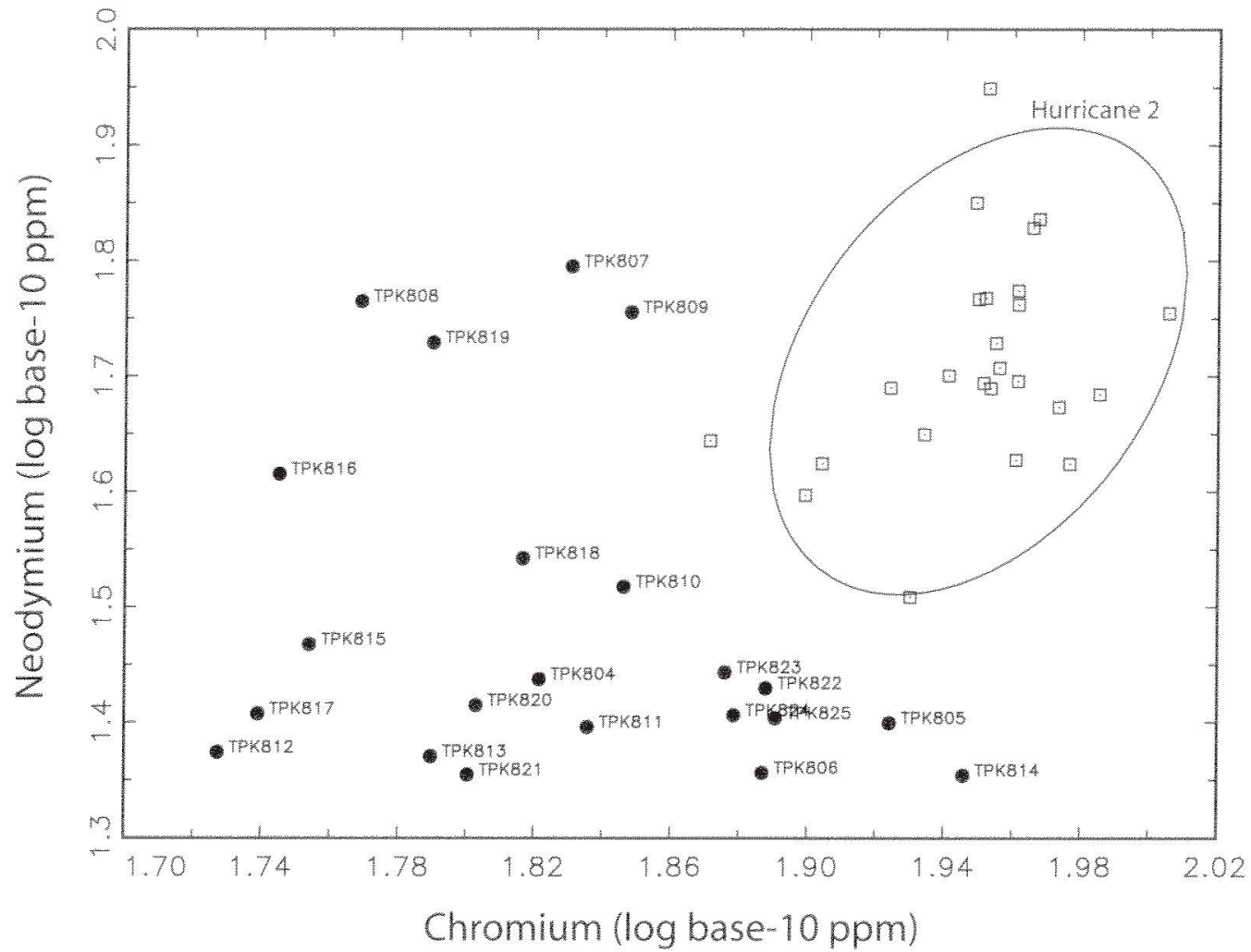

Figure 37. Bivariate plot of sodium and chromium base-10 logged concentrations showing the separation from the Hurricane 2 Reference Group. Ellipses represent a $90 \%$ confidence level for membership in the group.

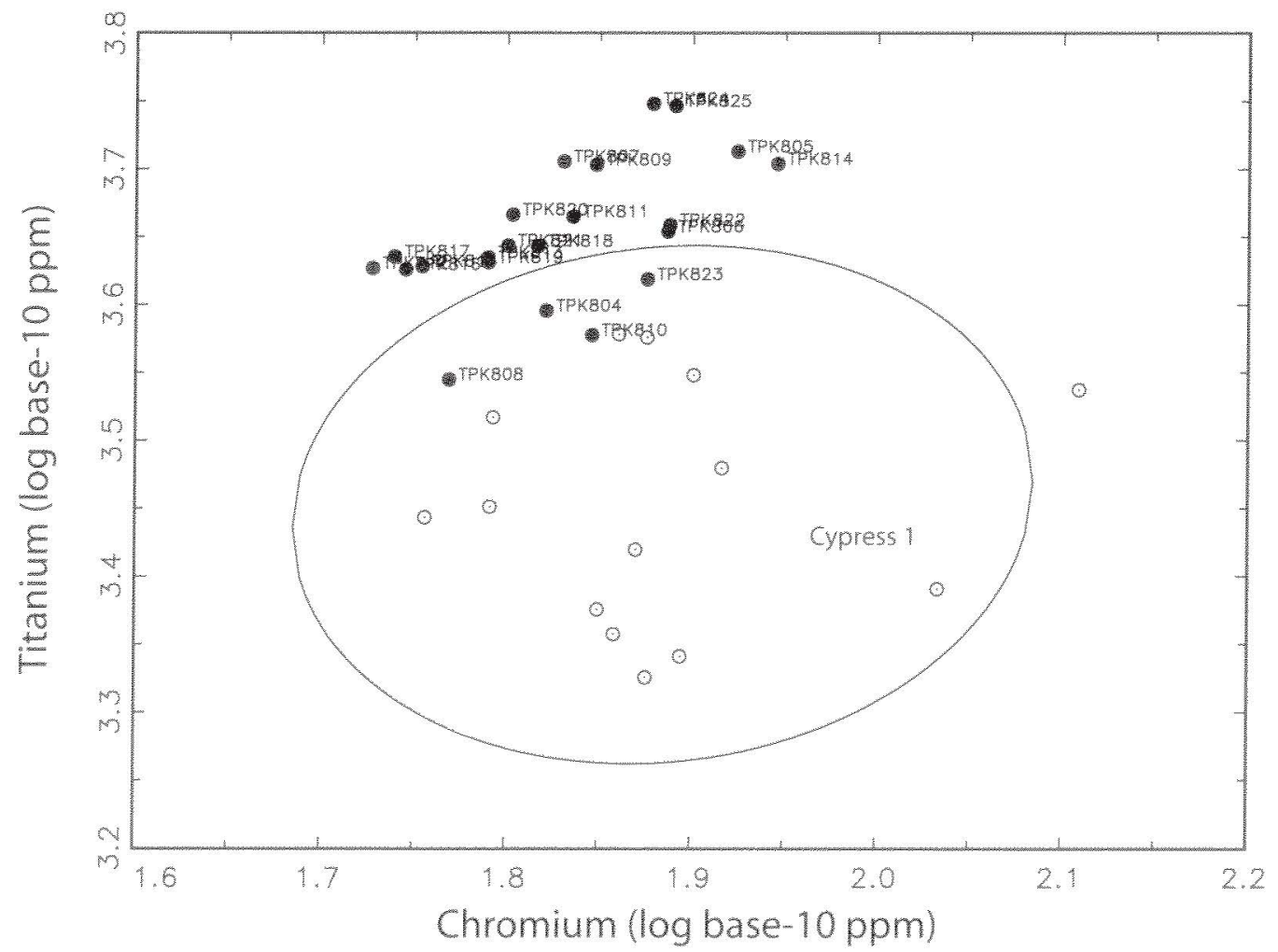

Figure 38. Bivariate plot of sodim and chromium base-10 logged concentrations showing he separation from the Cypress 1 Reference Group. Ellipses represent a $90 \%$ confudence level for membership in the group. 


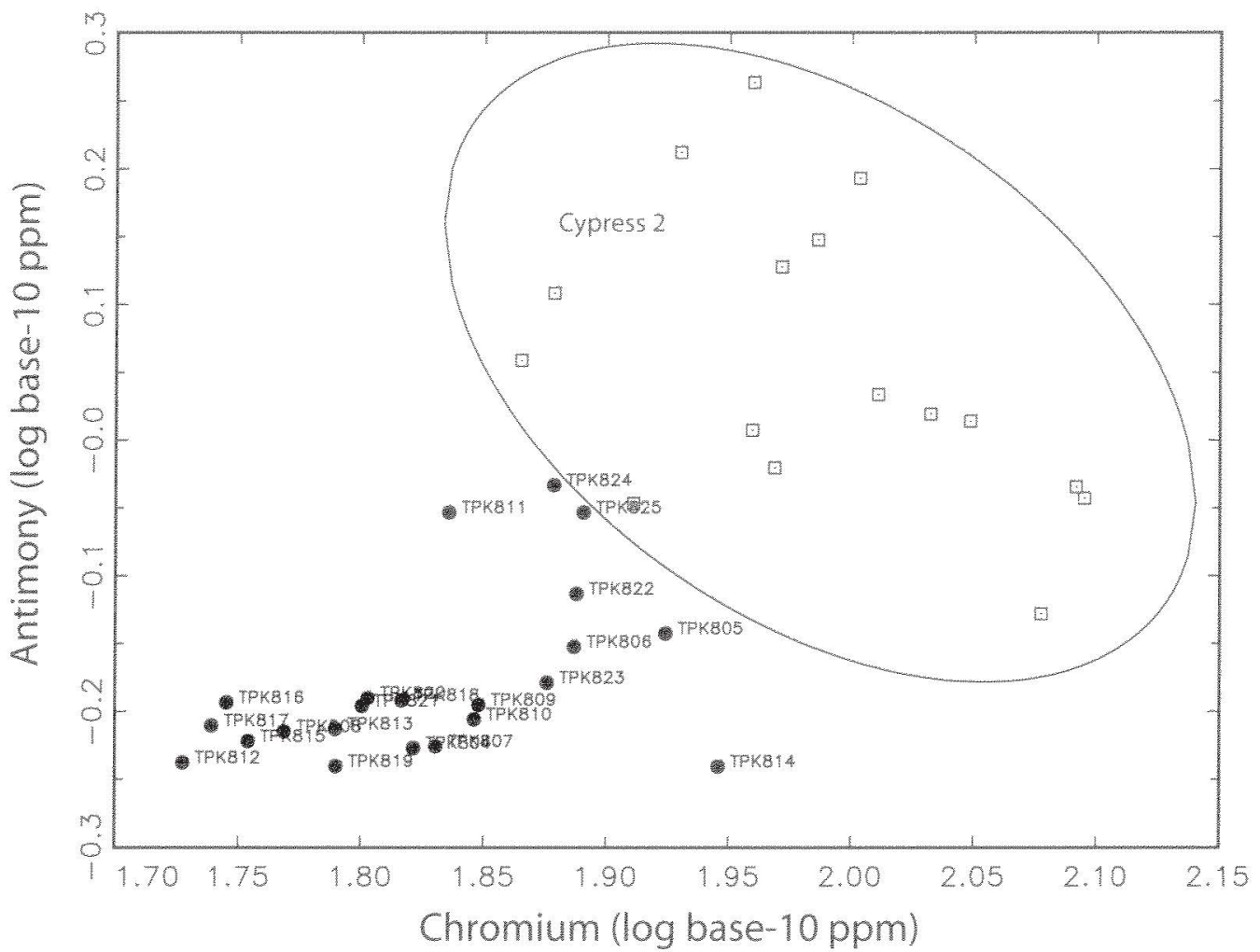

Figure 39. Bivariate plot of sodium and chromium base-10 logged concentrations showing the separation from the Cypress 2 Reference Group. Ellipses represent a $90 \%$ confidence level for membership in the group.

Table 17. Probabilites of group membership based on a Mahalanobis distance calculation for each of the sherds assigned to the Thus Rererence Group.

Mahalanobis distance calculation and posterior classification for two or more groups.

Variables used:

ASLALUND SMUYB CE COCR CSEUFEHF RB SB SC SRTA TB THZNZR

AL BA DYKMN NATIV

Probabilities are jackknied for specimens included in each group.

The following specimens are in the group TITUS

Probabilities:

$\begin{array}{lccc}\text { TD.NO. } & \text { ThUS } & \text { Smith } & \text { Red Rver } \\ \text { TPK804 } & 1.528 & 0.000 & 0.000 \\ \text { TPK805 } & 1.773 & 0.002 & 0.000 \\ \text { TPK806 } & 1.040 & 0.049 & 0.000 \\ \text { TPK807 } & 16.353 & 0.039 & 0.001 \\ \text { TPK809 } & 35.925 & 2.526 & 0.025\end{array}$


Table 17. (Continued)

\begin{tabular}{|lccc|}
\hline TPK810 & 93.667 & 0.105 & 0.000 \\
TPK811 & 1.243 & 0.000 & 0.000 \\
TPK812 & 3.499 & 0.046 & 0.000 \\
TPK818 & $\mathbf{2 . 9 8 2}$ & 0.002 & 0.000 \\
TPK819 & 40.699 & 0.004 & 0.000 \\
TPK822 & 35.309 & 0.294 & 0.000 \\
\hline
\end{tabular}

Table 18. Probabilities of group membership based on a Mahalanobis distance projection for each of the unassigned sherds. Sherds classified as likely members of Titus are shown in bold type.

Mahalanobis distance calculation for miscellaneous specimens projected against two or more groups.

Reference groups and numbers of specimens:

$\begin{array}{ccc}1 & \text { TITUS } & 241 \\ 2 & \text { SMTTH } & 48 \\ 3 & \text { REDRIVER } & 44\end{array}$

Variables used:

AS LA LU ND SM U YB CE CO CR CSEU FE HF RB SB SC SR TA TB TH ZN ZR AL BA DY K MN NA TIV

The following specimens are unassigned

Probabilities:

$\begin{array}{llll}\text { ID.NO. } & \text { TITUS } & \text { SMITH } & \text { RED RIVER } \\ \text { TPK808 } & 0.006 & 0.000 & \\ \text { TPK813 } & 0.012 & 0.000 & 0.000 \\ \text { TPK814 } & 0.849 & 0.057 & 0.000 \\ \text { TPK815 } & 0.431 & 0.003 & 0.000 \\ \text { TPK816 } & 0.003 & 0.001 & 0.000 \\ \text { TPK817 } & 0.004 & 0.000 & 0.000 \\ \text { TPK820 } & 0.921 & 0.019 & 0.000 \\ \text { TPK821 } & 0.018 & 0.002 & 0.000 \\ \text { TPK824 } & 0.229 & 0.002 & 0.000 \\ \text { TPK825 } & 0.000 & 0.000 & 0.000\end{array}$

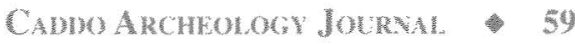




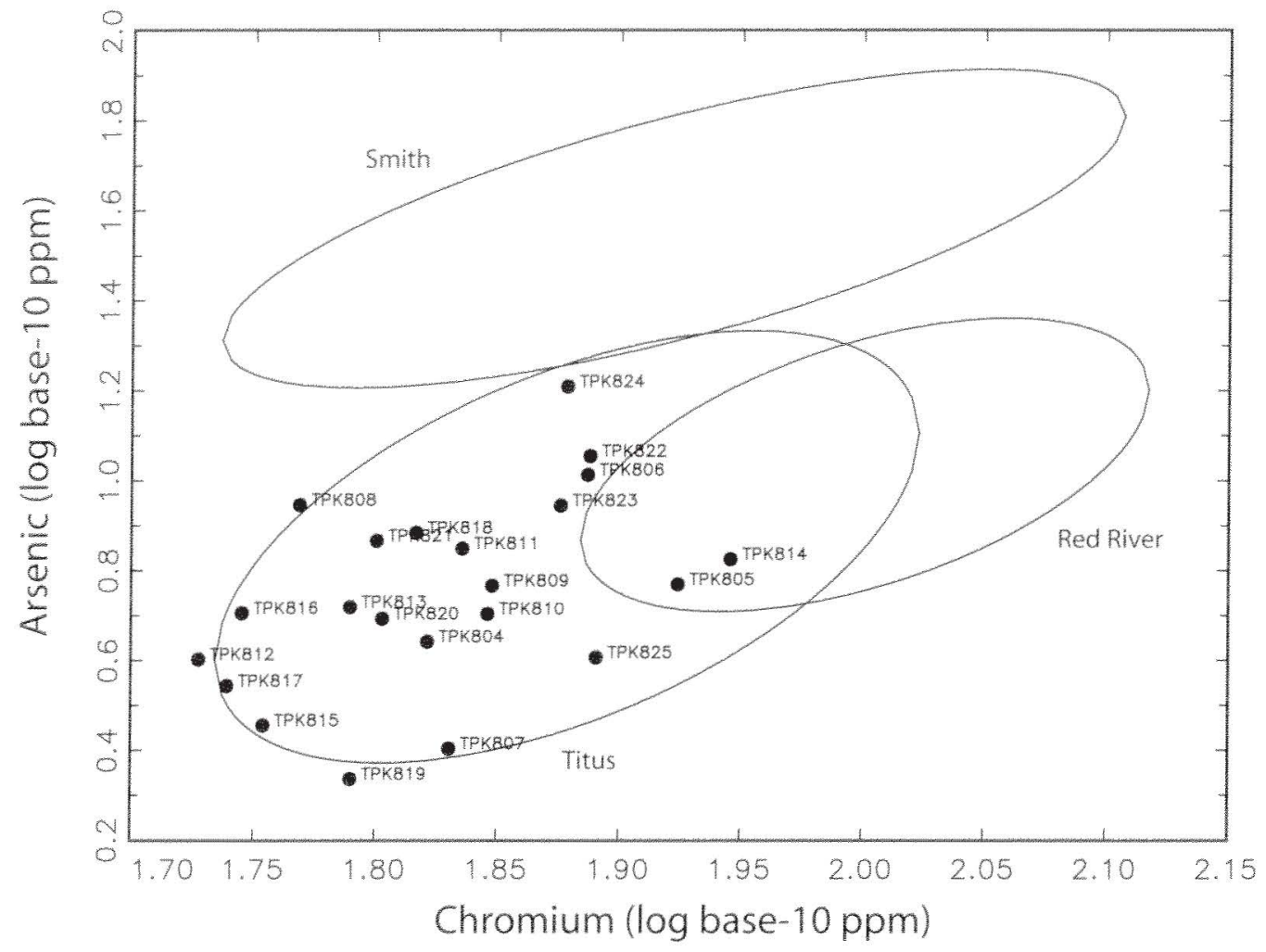

Figure 40 . Bivariate plot of arsenic and chromium base- 10 logged concentrations showing the relationship between the Leaning Rock samples and the three largest Caddo Reference Groups. Ellipses represent a $90 \%$ confidence level for membership in the group.

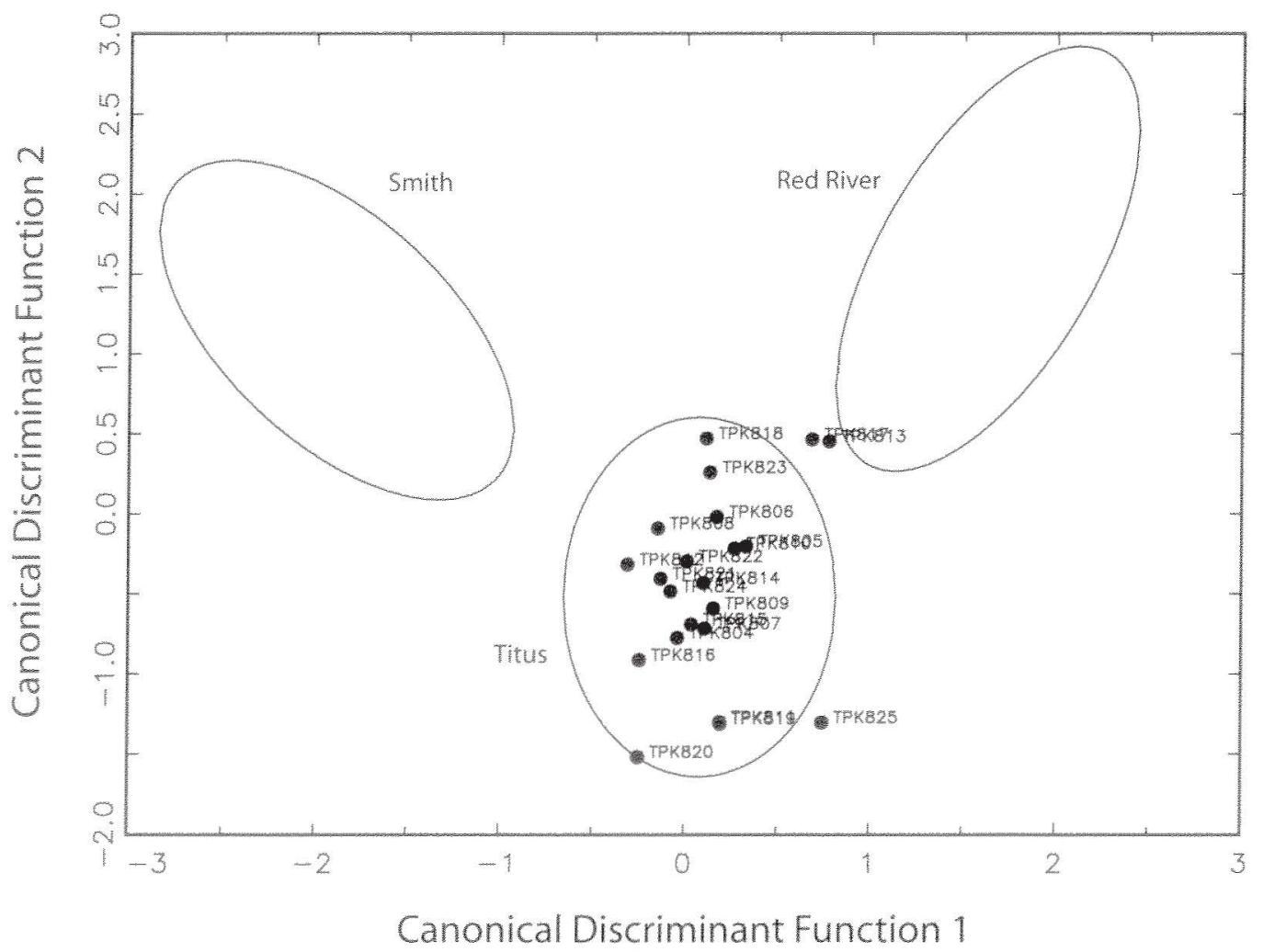

Figure 41. Biplot of canonical discriminant functions one and two showing the relationship between the Leaning Rock samples and the three largest Caddo Reference Groups. Ellpses represent a $90 \%$ confidence level for membership in the group. 
a $1 \%$ probability of group membership, and likely membership was assigned for samples with a $0.4 \%$ or greater probability. With the exception of a few sherds confidently assigned to the Titus group, none of the samples had probabilities greater than $0.01 \%$ of membership in either the Smith or Red River reference groups. Figure 40 is a bivariate plot of arsenic and chromium of the Leaning Rock samples and the three largest reference groups. Figure 41 shows the same groups according to canonical discriminant functions 1 and 2 , and clearly shows the exclusive association between the new samples and the Titus reference group.

\section{Clay Analysis}

Two samples of clay were submitted for analysis, and they are similar to the 20 sherds analyzed from the Leaning Rock site, as shown in Figures 34 through 41 . Interestingly, one of the clay samples (TKP 824) has a slight probability of membership in the Titus reference group (0.229\%), whereas the other clay sample (TKP825) has $0.000 \%$ probability of membership in Titus, Smith, or Red River reference groups. The ongoing reanalysis of the Caddo ceramic database, particularly the GIS mapping of each site location from which sherds have been analyzed, may illuminate the production locations for the Leaning Rock sherds better. As of now, it appears that they might have been made from local clays, but the geographic distribution of the Titus reference group sherds is not yet available in order to assess the probability of non-local manufacture.

\section{CONCLUSIONS}

Of the 20 sherds analyzed from the Leaning Rock Site, 12 are assigned to the Titus reference group, three are tentatively assigned to that group, and five are unassigned. Both clay samples are unassigned, but one (TKP824) might be slightly related to the Titus reference group. These findings should be considered preliminary until the reanalysis of the entire Caddo database, currently underway, is completed.

\section{LOCALAND REGIONAL CERAMIC COMPARISONS}

\section{Timothy K. Pertula}

In this section, I examine the decorated ceramic vessel sherd assemblages from other contemporaneous Middle Caddo sites in the middle reaches of the Sabine River basin (Table 19). Middle Caddo period ceramics, as seen from the ceramic vessel sherds found on sites, from this part of the Sabine River basin are diverse in decorative treatment, use of tempers, and in the relative abundance of plain ware vessels. This diversity in vessel decoration and manufacture suggest the existence of several different Caddo communities living in the area around and after ca. A.D. 1200-1250. At that time, the cultural landscape of the Caddo people along the middle Sabine was changing dramatically, as the land was filling up with people, but locally and socially independent communities were developing their own ethnic and stylistic expressions (Perttula and Rogers 2007:90-91).

The ceramics on Middle Sabine River basin Caddo sites, including the Leaning Rock site, are represented almost exclusively by six primary decorative treatments: brushing, punctation, engraving, incising, incised-punctated, and brushed-punctated (see Table 19). Pre-A.D. 1250 Caddo sites in this area do not have brushed or brushedpunctated utility wares (see Bruseth and Perttula 2006: Table 3) in their ceramic sherd assemblages.

At Leaning Rock, incised vessel sherds are the most common kind of decorated sherd, followed by those that are brushed, punctated, and engraved vessel sherds. Approximately 16\% of the decorated vessel sherds are bone-tempered. Leaning Rock also has a significant plain ware assemblage, based on a decorated sherd/plain 
rim ratio of only 5.3:1 (see Table 6). Other Middle Caddo sites in this part of the Middle Sabine that are broadly similar to the Leaning Rock site in terms of their ceramic vessel sherds are Redwine (Walters et al. 1998) and Bryan Hardy (Walters and Haskins 2000). Perttula and Rogers (2007: Figure 12) consider the Iatter two sites to be part of a distinct Middle Caddo period ceramic complex, and I include Leaning Rock in that ceramic complex. The INAA results from the Leaning Rock site (see Ferguson et al., above) indicate that the decorated and plain ceramics (both utility ware and fine ware) that are a part of this Middle Caddo ceramic complex were made from local clay sources.

Even within this distinct ceramic complex with Caddo sites radiocarbon-dated to between A.D. 1300-1430 (cal), there are some subtle and not so subtle stylistic and technological differences, hinting at micro-scale social and/or temporal differences in ceramic traditions. The use of bone temper is very abundant at Redwine (45\%),

Table 19. Comparison of Middle Caddo Ceramic Assemblages in the Sabine River basin, East Texas.

\begin{tabular}{|c|c|c|c|c|c|}
\hline $\begin{array}{l}\text { Decorated } \\
\text { Sherds }\end{array}$ & $\begin{array}{c}\text { Leaning Rock } \\
\text { (41SM325) }\end{array}$ & $\begin{array}{l}\text { Oak Hill } \\
\text { (4IRK214) }\end{array}$ & $\begin{array}{l}\text { Redwine } \\
\text { (4ISM193) }\end{array}$ & $\begin{array}{c}\text { Nawi haia ina } \\
(41 \text { RK } 170)\end{array}$ & $\begin{array}{c}\text { Bryan Hardy } \\
\text { (41SM55) }\end{array}$ \\
\hline N & 693 & 3958 & 597 & 651 & 729 \\
\hline Rattlesnake el. & $* *$ & $* *$ & - & - & - \\
\hline Plain rims & 130 & 331 & 65 & 92 & 37 \\
\hline \multicolumn{5}{|l|}{ Decorated: Plain } & $19.7: 1$ \\
\hline \multicolumn{6}{|l|}{$\begin{array}{l}\text { Percent bone- } \\
\text { tempered }\end{array}$} \\
\hline \multicolumn{6}{|c|}{ Principal Decorative Classes } \\
\hline Brushed & $17.0 \%$ & 13.8 & 27.8 & 2.8 & 20.4 \\
\hline Punctated & 16.3 & 37.2 & 19.1 & 30.0 & 25.1 \\
\hline Engraved & 16.3 & 11.5 & 22.6 & 22.0 & 6.6 \\
\hline Incised & 35.8 & 19.4 & 13.4 & 25.7 & 20.9 \\
\hline $\begin{array}{l}\text { Incised-Punctated } \\
\text { Brushed- }\end{array}$ & 8.2 & Brushed- & 7.0 & 16.0 & 5.5 \\
\hline Punctated & 2.0 & 4.6 & 7.7 & 1.8 & 15.6 \\
\hline \multicolumn{6}{|c|}{ Minor Decorative Classes } \\
\hline Pinched & 0.4 & 0.6 & 1.3 & - & 2.1 \\
\hline Red-slipped & 0.3 & 0.6 & 1.0 & 0.3 & 0.8 \\
\hline Incised-appliqued & - & Trace & -- & 0.1 & - \\
\hline Brushed-incised & 1.9 & 0.4 & - & 0.1 & 2.2 \\
\hline $\begin{array}{l}\text { Brushed- } \\
\text { Punctated-appliqu }\end{array}$ & ued 0.1 & 0.3 & - & 0.1 & 0.7 \\
\hline
\end{tabular}


Table 19. (Continued)

\begin{tabular}{|c|c|c|c|c|c|}
\hline $\begin{array}{l}\text { Decorated } \\
\text { Sherds }\end{array}$ & $\begin{array}{l}\text { Leaning Rock } \\
\text { (4ISM325) }\end{array}$ & $\begin{array}{l}\text { Oak Hill } \\
\text { (4lRK214) }\end{array}$ & $\begin{array}{l}\text { Redwine } \\
\text { (4ISM193) }\end{array}$ & $\begin{array}{l}\text { Nawi haia ina } \\
(41 \text { RK } 170)\end{array}$ & $\begin{array}{l}\text { Bryan Hardy } \\
\text { (41SM55) }\end{array}$ \\
\hline \multicolumn{6}{|c|}{ Minor Decorative Classes, continued } \\
\hline \multicolumn{6}{|c|}{ Brushed- } \\
\hline Lip notched & 0.1 & Trace & & 0.8 & - \\
\hline \multicolumn{6}{|l|}{ Washington $\mathrm{Sq}$. } \\
\hline Paneled & 0.6 & $* *$ & $* *$ & & - \\
\hline Appliqued & 0.3 & 0.2 & & & 0.1 \\
\hline Brushed-pinched & 0.3 & & - & -. & - \\
\hline \multicolumn{6}{|l|}{ Appliqued- } \\
\hline Punctated & 0.1 & Trace & - & - & - \\
\hline $\begin{array}{l}\text { Appliqued- } \\
\text { Brushed-punctated }\end{array}$ & - & 0.5 & - & - & - \\
\hline Trailed-incised & - & Trace & - & - & - \\
\hline $\begin{array}{l}\text { Decorated } \\
\text { Sherds }\end{array}$ & \multicolumn{4}{|c|}{ Sherds } & \\
\hline $\mathrm{N}$ & 187 & 280 & & & \\
\hline Rattlesnake el. & -+ & - & & & \\
\hline Plain rims & 5 & 10 & & & \\
\hline $\begin{array}{l}\text { Decorated: Plain } \\
\text { Rim Ratio }\end{array}$ & $37.4: 1$ & $28: 1$ & & & \\
\hline $\begin{array}{l}\text { Percent bone- } \\
\text { tempered }\end{array}$ & 16.5 & 10.4 & & & \\
\hline \multicolumn{6}{|c|}{ Principal Decorative Classes } \\
\hline Brushed & 32.6 & 10.4 & & & \\
\hline Punctated & 17.7 & 36.1 & & & \\
\hline Engraved & 12.8 & 27.9 & & & \\
\hline Incised & 4.8 & 15.4 & & & \\
\hline Incised-Punctated & 10.2 & 6.8 & & & \\
\hline $\begin{array}{l}\text { Brushed- } \\
\text { Punctated }\end{array}$ & 11.8 & 0.4 & & & \\
\hline
\end{tabular}


Table 19. (Cominued)

\begin{tabular}{|c|c|c|}
\hline $\begin{array}{l}\text { Decorated } \\
\text { Sherds }\end{array}$ & $41 R K 240$ & $41 \mathrm{RK} 243$ \\
\hline \multicolumn{3}{|c|}{ Minor Decorative Classes } \\
\hline Pinched & 3.7 & \\
\hline Red-slipped & & \\
\hline Incised-appliqued & & \\
\hline Brushed-incised & 3.2 & 2.8 \\
\hline $\begin{array}{l}\text { Brushed- } \\
\text { Punctated-appliqued }\end{array}$ & & \\
\hline $\begin{array}{l}\text { Brushed- } \\
\text { Appliqued }\end{array}$ & - & - \\
\hline Lip notched & - & - \\
\hline $\begin{array}{l}\text { Washington Sq. } \\
\text { Paneled }\end{array}$ & *** & + \\
\hline Appliqued & - & 0.7 \\
\hline Brushed-pinched & - & - \\
\hline $\begin{array}{l}\text { Appliqued- } \\
\text { Punctated }\end{array}$ & - & - \\
\hline $\begin{array}{l}\text { Appliqued- } \\
\text { Brushed-punctated }\end{array}$ & 1.1 & - \\
\hline Trailed-incised & - & - \\
\hline \multicolumn{3}{|c|}{$\begin{array}{l}\text { "percentage } \\
\text { ** Present } \\
\text { - a rattlesnake decorated sherd is present at } 41 \text { RK242 (Pertula 2001a:Figure 30i) } \\
\text { S- Washington Square Paneled rim sherd is present at } 41 \text { RK276 (Perttula 2001a:Figure 32) } \\
\text { Sources: Leaning Rock (this paper); Oak Hill (Pertula 2004b); Redwine (Walters et al. 1998); Nawi haia ina } \\
\text { (Perttula and Nelson 2003); Bryan Hardy (Walters and Haskins 2000): } 4 \text { (RK240 (Pertula 2001a), } 4 \text { IRK243 } \\
\text { (Perttula 2001a, 2001b) }\end{array}$} \\
\hline
\end{tabular}

but much less so at Bryan Hardy and Leaning Rock. Plain wares are particularly abundant at Leaning Rock and Redwine. but considerably less at the Bryan Hardy site (see Table 19). With respect to broad ceramic decorative methods/treatments, engraved fine wares are most common at Leaning Rock and Redwine, while incised vessel sherds dominate the decorated sherds at Leaning Rock. Conversely, brushed-punctated sherds--most often seen on Caddo sites in the region that were occupied after ca. A.D. 1350-are 4.8 times more common at Redwine and Bryan Hardy than they are at the Leaning Rock site. The Redwine and Bryan Hardy sites were probably occupled by the Caddo contemporaneously with the Caddo settlement at Leaning Rock. but then also for some time (1-2 generations) after the Leaning Rock site was abandoned.

A second Middle Caddo ceramic complex includes three settlements in the Martin Creek drainage basin, 20-50 km east of the Leaning Rock-Redwine-Bryan Hardy ceramic complex (see Perttula and Rogers 2007: Figure 12). These sites are Oak Hill (4IRK214), 4IRK240, and 4IRK243 (Perttula 2001a. 2001b, 2004b). One difference between these sites and Leaning Rock is the low occurrence of plain wares in the Martin Creek basin 
sites: decorated sherd/plain rim ratios that range from 12:1 to 37:1, compared to $5.3: 1$ at Leaning Rock. Site 41 RK240 is consistently different from the Oak Hill site or 4IRK243 in the relative proportions of ceramic decorative treatments among the major decorative methods (see Table 19). This difference is considered to be primarily a temporal one, given the higher frequencies of brushed $(32.6 \%)$ and brushed-punctated $(11.8 \%)$ sherds at 41RK240. This site also has the lowest amount of plain ware vessels (see Table 19).

The Naw haia ina site (4IRK170, see Perttula and Nelson 2003) is part of a third related Middle Caddo ceramic complex. This site is ca. $10 \mathrm{~km}$ south of the Oak Hill ceramic complex (see Perttula and Rogers 2007: Figures 1 and 12). This particular Middle Caddo ceramic assemblage is distinctive for its very low frequency of brushed (2.8\%) or brushed-punctated (1.8\%) sherds among the utility wares, but abundant amounts of incised-punctated (16.0\%) sherds; the latter are twice as common here as they are in the Leaning Rock or Oak Hill ceramic complexes. Punctated, incised, and engraved sherds are also more popular decorative treatments in the Nawi haia ina site ceramic sherd assemblage than is generally the case in either the Leaning Rock or Oak Hill ceramic complexes.

\section{SUMMARY OF THE LEANING ROCK SITE (41SM325) DECORATED SHERD ASSEMBLAGE}

\section{Timorhy K. Pertula}

The prehistoric Caddo ceramic assemblage from the Leaning Rock site is from a single component 14 th century Middle Caddo period settlement in the middle reaches of the Sabine River basin in East Texas. Investigations have produced a large and stylistically diverse domestic Caddo ceramic vessel sherd collection from a nonmortuary and non-mound context.

The Leaning Rock site ceramic decorated vessel sherd assemblage (as well as the plain ware rim sherds) includes a range of vessel sizes, including a number that are greater than $22 \mathrm{~cm}$ in orifice diameter. The utility ware vessel sherds at the site are decorated with incised, brushed, punctated, and incised-punctated designs, as well as a small number that have brushed-punctated and brushed-incised decorations. There are also engraved fine ware sherds from carinated bowls, bowls, and bottles, a number of which have a red pigment worked into the design. Most of the utility ware and fine ware decorations are geometric elements, including cross-hatching, diagonal lines, opposed lines, or horizontal lines or rows of decorations. One new engraved type-Leaning Rock Engraved--is present in the fine wares from the site.

The Leaning Rock decorated sherds are from vessels primarily tempered with grog, with a moderate use of bone or hematite as additional temper inclusions. These same vessels were fired usually in a reducing or low oxygen environment to produce serviceable and durable vessels less subject to heat-related stresses, cracks, or fractures. The INAA results indicate that both fine wares and utility wares were likely made at the site or in the general locality using locally available clays.

Clear differences in temper, firing conditions, and the kinds of decorations placed on vessel rims and body surfaces are apparent in the Leaning Rock sherds between the fine wares and the utility wares. These differences can be readily traced to specific technological, functional, and stylistic decisions made by the Caddo potters living at the Leaning Rock site on how to make, finish, and decorate ceramic vessels that were used in domestic tasks here. The Leaning Rock ceramic vessels are part of a larger Middle Caddo ceramic complex in the middle reaches of the Sabine River basin in northeastern Texas. 


\section{MUD DAUBER WASP NESTS}

Dirt-dauber or mud dauber wasp (Sceliphron caementarium) belong to the Family Sphecidae. Nests are usually constructed in protected areas such as inside barns or under house eaves. The Black and Yellow mud dauber builds a series of cylindrical cells that are eventually plastered over with mud to form a smooth mud nest about the size of a fist. This is the type of nest found in exeavations at Leaning Rock (Figure 42). The nest would need to be thermally altered, such as in a house fire, to have survived in the archeological record. Otherwise the nest would have eventually dissolved. The fact that at least two of the nests are intact also indicates that whatever they were attached to probably also burned since it would be impossible to pry one off of its support without destroying it. Fired mud dauber nests were recovered from four contexts in the excavations: Unit $3,22 \mathrm{~cm}$ bs; Unit 11, 30-40 cm; Unit 12, 30-40 cm, and Unit 13,30-40 cm.

\section{FIRED CLAY/DAUB}

There were 10 pieces of fred clay/daub (160.5 g) collected from the surface and excavations at Leaning Rock (Table 20). Like most Caddo sites south of the Sabine River, daub and/or fired clay are scarce items at Leaning Rock. There is no reason that Caddo groups south of the Sabine River did not have houses burn, either intentionally or unintentionally, which is how daub is preserved. That a structure burned at the site is evident from the preserved mud dauber nests. This would suggest that Caddo peoples south of the river may have practiced a different type of house construction that did not use both wattle and daub.

\section{MODIFIED CANE OBJECT}

There was a segment of charred giant

Figure 42. Mud dauber nest. cane (Arundinaria gigantea) recovered from Feature 5 between $80-90 \mathrm{~cm}$ bs that showed evidence of having been modified or altered for some unknown use. Giant or river cane, a perennial, is a native bamboo that is well adapted to swampy areas. Early explorers in the Caddo area remarked on canebrakes that were miles in length and so dense as to be impenetrable. The canebrakes also provided habitat for the canebrake rattlesnake, a snake that played an important role in Caddo mythology (Walters 2006).

Bamboo is a highly versatile native plant that the Caddo certainly must have utilized in many ways. It can be used as wood for construction work, furniture, utensils, fiber, fuel, and innumerable small articles (Farrelly 1984). Bamboo is lightweight, very strong, and pliable when green. It also splits easily and would have been used for weaving baskets and mats such as its use in the Yucatan today as a substitute for plywood sheeting. The bamboo would have made excellent arrow shafts and when sharpened could have been used as a knife or 
Table 20. Fired Clay/Daub.

\begin{tabular}{|c|c|c|}
\hline Provenience & Depth & Comments \\
\hline TU 9, Fea. 2 & $30-44 \mathrm{~cm}$ & $\begin{array}{l}4 \mathrm{~cm} \text { diameter rough ball of fired clay with small stick } \\
\text { impressions on one side }(5.3 \mathrm{~g})\end{array}$ \\
\hline TU 1 & $20-30 \mathrm{~cm}$ & $\begin{array}{l}\text { (1) } 2.5 \mathrm{~cm} \text { diameter rough ball of fired red clay }(13.7 \mathrm{~g}) \\
\text { (2) } 4 \mathrm{~cm} \text { diameter rough ball with organic inclusions }(31.1 \mathrm{~g}) \\
3 \mathrm{~cm} \text { diameter rough ball with hematite inclusions ( } 19.8 \mathrm{~g}) \\
2 \mathrm{~cm} \text { diameter rough ball with grass/small stick impressions }(5.3 \mathrm{~g})\end{array}$ \\
\hline TU 12, Fea. 5 & $70-80 \mathrm{~cm}$ & $\begin{array}{l}\text { (1) } 4.5 \times 3.5 \times 3.5 \text { diameter oblong fired clay with lateral stick } \\
\text { impressions on two sides }(42.8 \mathrm{~g} \text { ) } \\
\text { (2) } 4.5 \times 1 \mathrm{~cm} \text { diameter fired clay coil }(7.5 \mathrm{~g}) \\
\text { (1) } 2.5 \times 2.5 \mathrm{~cm} \text { rough ball of fired clay }(12.1 \mathrm{~g})\end{array}$ \\
\hline TU 13 & $20-30 \mathrm{~cm}$ & $4 \mathrm{~cm}$ diameter rough ball with stick impression on one side ( $19.2 \mathrm{~g}$ ) \\
\hline Surface & general & $2.5 \mathrm{~cm}$ diameter $\mathrm{x} 1 \mathrm{~cm}$ thick fired clay with grass impressions $(3.7 \mathrm{~g}$ ) \\
\hline
\end{tabular}

tattooing needle. Young shoots can be eaten as a pot herb.

The Leaning Rock specimen was a split section of cane that was $46.13 \mathrm{~mm}$ in length, but broken on one end. It was $7.7 \mathrm{~mm}$ wide on the exterior surface, narrowing to $5.5 \mathrm{~mm}$ wide on the interior surface with the beveled split edges showed evidence of smoothing or sanding. The wall of the cane object was $2.7 \mathrm{~mm}$ thick. There was a $1.3 \mathrm{~mm}$ diameter hole drilled in the unbroken end (Figure 43). A small area on the exterior surface where the hole was drilled had been sanded flat, perhaps to construct a platform to drill the hole rather than try and drill a hole on a curved and slick surface.
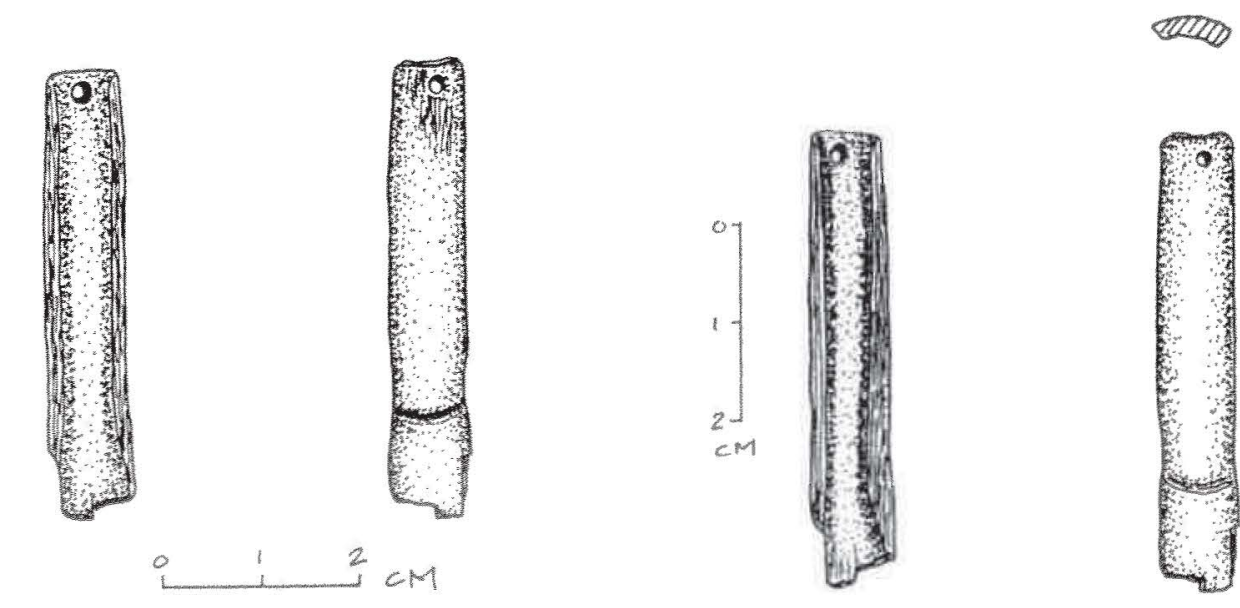

Figure 43. Drawing by LeeAnna Schniebs of several views of the modified cane object from Feature 5 , $80-90 \mathrm{~cm}$ bs. 


\section{PLANT REMAINS FROM THE LEANING ROCK SITE (41SM325)}

\section{J. Phil Dering}

The purpose of this analysis is to provide an assessment of the different kinds of plant remains recovered from the Leaning Rock site and to document their distribution. The analysis is first based on four flotation samples from Feature I (Unit 7, 14-31 cm bs and Unit $8,20-30 \mathrm{~cm}$ bs) totaling 20.0 liters; the flotation effort averaged 5 liters per sample. Two of the samples, Flot-1 and Flot-2, were floated by Mark Walters. The other two samples, Flot-3 and Flot -4 , were floated by Phil Dering. Additionally several maize cobs and fragments were submitted for analysis. Subsequently, nine more flotation samples and nine macrobotanical samples were also submitted for analysis. These additional flotation samples were collected from Features 1 and 2 , and from four non-feature contexts. Pre-flotation volume of these sediment samples totaled 45 liters, an average of 5 liters per sample. All told, 65 liters of archeological sediments were processed as part of this analysis.

\section{LABORATORY METHODS}

Flotation is the process by which organic remains, especially charred plant fragments, are recovered from archeological sediments using water as the separating agent. The first four samples were recovered from two proveniences and were processed using two different methods. The purpose of dual samples was to compare collection techniques. Therefore, each provenience is represented by two flotation samples, each processed slightly differently.

Sample numbers Flot-1 and Flot-2 were processed by Mark Walters using a simple 5 gallon bucket device designed by Bo Nelson, along with the nine additional flotation samples discussed below. The soil sample, up to 2 liters or so in volume, were agitated by water pressure while gently stirring the mixture. The light fraction was captured as it floated to the surface and exited the bucket via a 3 -inch PVC elbow positioned through the bucket near the top. Ladies ' hose was used as a handy screen and was fastened to the elbow by a rubber band. After the light fraction was collected, the heavy fraction remaining at the bottom of the bucket was water-screened through $1 / 64$ th-inch window screen.

Sample numbers Flot-3 and Flot-4 were processed by Phil Dering using a simple screen and swirl technique by pouring the sample into 5 gallon, water-filled buckets. The samples were stirred gently with a narrow metal rod, and rocked back and forth. The heavy material, consisting of rocks, some bone, and occasionally heartwood or nut charcoal, falls to the bottom of the bucket, and the lighter material, including most of the plant material, both carbonized and uncarbonized, floats to the surface. The floating material is directed onto a 0.45 $\mathrm{mm}$ screen, a mesh small enough to catch the smallest seeds, such as tobacco. This floating material is called the light fraction. The material that sinks to the bottom, termed the heavy fraction, is passed through a $1 \mathrm{~mm}$ stainless steel screen.

Both fractions were tagged and dried slowly before they were sorted and examined in the laboratory using a stereomicroscope. After the material is dry, both fractions of each flotation sample are passed through a nested set of screens of $4 \mathrm{~mm}, 2 \mathrm{~mm}, 1 \mathrm{~mm}$, and $0.450 \mathrm{~mm}$ mesh and examined for charred material that is separated for identification. Plant remains were sorted into three categories--woody fragments, nut fragments, and seed/ fruit fragments including maize parts. Identification of carbonized wood was accomplished by using the snap technique, examining the fragments at 8 to 45 magnifications with a hand lens or a binocular dissecting microscope, and comparing the material to samples in the archeobotanical herbarium. All seed identifications were made using seed manuals and reference collections at Shumla Archeobotanical Services, Maize cobs and parts 
were measured to the nearest $0.1 \mathrm{~mm}$ using a set of electronic calipers. Measurement and description followed procedures described by Wagner (1986).

Carbonized wood from the $4 \mathrm{~mm}$ and $2 \mathrm{~mm}$ screens (smaller pieces are seldom identifiable) is separated in a 25 piece grab sample and identified and each category is weighed. Care is taken to select representative materials from both levels (cf. Diehl 2003:213; Huckell 2002:645; Miksicek 1994:243). If the sample contains a large quantity of charred wood (i.e., more than 25 charcoal fragments), a grab sample of 25 fragments is first selected and identified. Then the remaining material is scanned and separated into taxonomic categories, but not individually counted. The volume of each taxon or type in the remaining material is measured, and then the material weighed to the nearest $0.1 \mathrm{~g}$.

Macrobotanical samples are carbonized plant remains that are collected by hand, either from an excavator's screen or point-collected in situ. Macrobotanical samples were recovered from Features 2 and 5 , and several non-feature contexts.

At the vast majority of open sites, only carbonized plant remains are considered to be potentially a part of the archeological record. In some rare cases certain durable and easily identifiable wood types such as juniper may survive in a partially carbonized state, but primarily at younger sites in relatively dry conditions. Deposits in the current study have been exposed to the elements for a sufficient time period that only carbonized plant material is included in the archeological record.

\section{DISTURBANCE INDICATORS}

Sample content may be affected by various biological disturbance factors, including insect or small mammal activity, and plant root growth. In an effort to assess this impact, the amounts of insect parts, termite pellets, gastropods, mammal remains (including fecal pellets), and modern uncharred seeds are estimated for each flotation sample. These amounts are reported on a scale of 1-25 fragments or units $(+), 25-50$ $(++)$, and over $50(+++)$. Termite pellets occur in higher numbers when samples are taken from an area containing wood that has been exposed to the elements for a long time before burning. In the desert, this can occur in dead trees or roots, in which case the termite pellets can appear in any locus that this wood is burned, such as in a hearth or roasting pit. However, evidence of termite infestations seems to be more abundant in samples drawn from the remains of burned prehistoric habitations with vertical elements constructed of wood.

\section{RESULTS AND DISCUSSION}

The overview in Table 21 summarizes flotation sample volume, seed density, seed taxa abundance, and disturbance indicators for the first four flotation samples from Feature 1. Table 22 presents the identifications and counts of material recovered from the flotation samples.

Disturbance indicators were abundant, and these four flotation samples contained a large quantity of roots and some insect parts. This is typical of Caddo sites. Results from each method of flotation from each provenience were comparable. Nut charcoal was much more abundant than wood charcoal in both contexts, and total charcoal from Flots 2 and 4 , the Feature 1 provenience, measured within $0.01 \mathrm{~g}$.

The samples from TU-8 (Flots 1 and 3) contained a small quantity of oak and hickory wood, and 139 hickory nut fragments weighing $0.8 \mathrm{~g}$. In addition, a single maize cupule fragment was recovered from Flot-1. The 


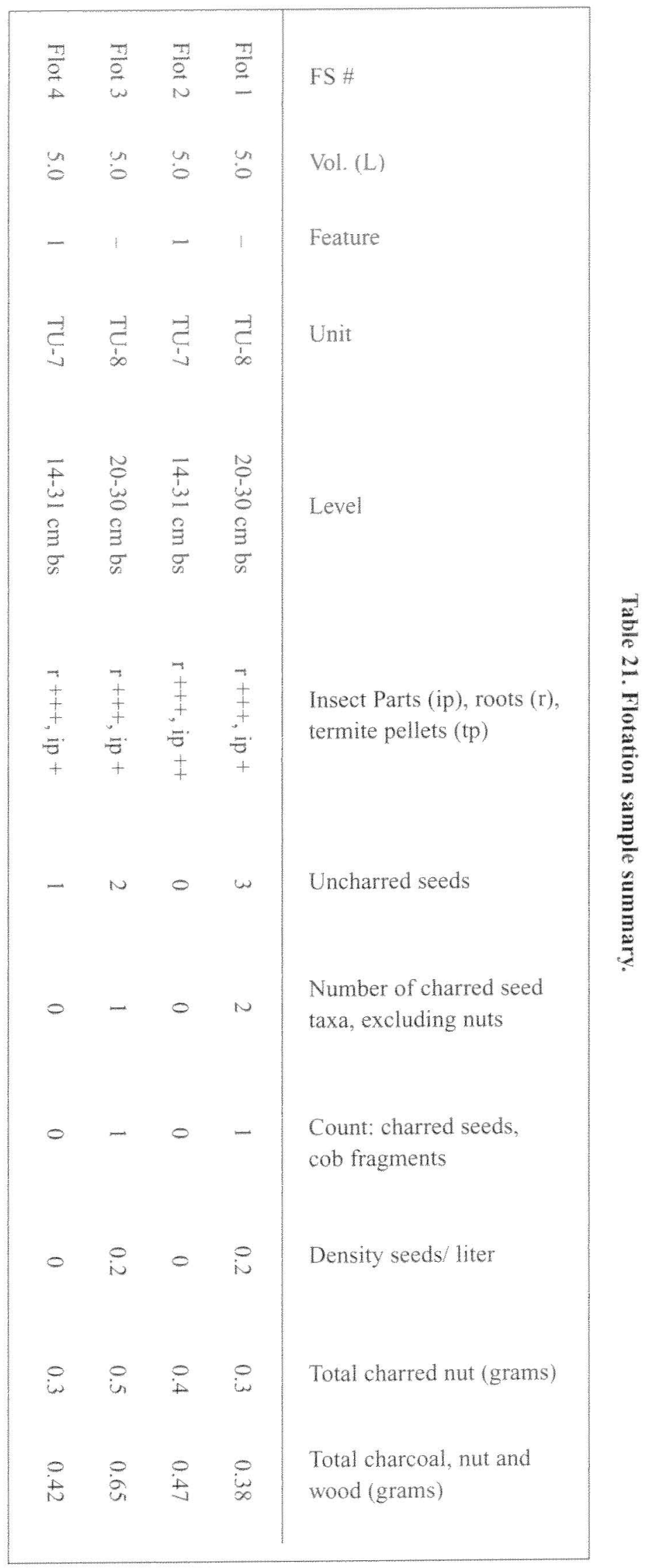


Table 22. Flotation sample counts.

\begin{tabular}{|c|c|c|c|c|c|c|c|}
\hline Sample\# & Unit & Feature & Taxon & Common & Part & Count & Wt $(g)$ \\
\hline mot 1 & TU.8 & $-\cdots$ & Quencus sp. & Oak & Wood & 6 & 0.02 \\
\hline Flot 1 & TU-8 & - & Caryasp. & Hickory & Wood & 5 & 0.04 \\
\hline Flot 1 & TU-8 & - & Canyasp. & Hickory & Nut & 61 & 0.3 \\
\hline Flot 1 & TU-8 & - & Zea mays & Maize & Cupule fragment & 1 & 0.02 \\
\hline Flot 3 & TU.8 & - & Camasp. & Hickory & Nut & 78 & 0.5 \\
\hline Flot 3 & TU-8 & -.. & Quercus sp. & Oak & Wood & 14 & 0.05 \\
\hline Flot 3 & TU-8 & - & Canasp. & Hickory & Wood & 7 & 0.1 \\
\hline Flot 2 & TU-7 & 1 & Caryasp. & Hickory & Nut & 20 & 0.4 \\
\hline Flot 2 & TU.7 & 1 & Quercus sp. & Oak & Wood & 2 & 0.02 \\
\hline Flot 2 & TU.7 & 1 & Carya sp. & Hickory & Wood & 7 & 0.05 \\
\hline Flot 4 & TU-7 & 1 & Coryasp. & Hickory & Wood & 12 & 0.05 \\
\hline Flot 4 & TU.7 & 1 & Carya sp. & Hickory & Nut & 18 & 0.3 \\
\hline Flot 4 & TU-7 & 1 & Quercus sp. & Oak & Wood & 6 & 0.07 \\
\hline
\end{tabular}

samples from TU-7 (Flots 2 and 4) were very similar, containing a total of 38 nut fragments weighing $0.8 \mathrm{~g}$. Wood included oak and hickory.

Seven maize samples were submitted for description. These samples exhibited some diversity in row number: The cobs that were complete enough to provide row numbers included a 10-row cob and a 14-row cob. Two other samples were estimated to be 8 - and 12-row cobs. The small sample suggests that the maize crop was diverse.

The light fractions of the nine additional flotation samples from the Leaning Rock site were relatively small (Table 23). They did, however, contain charred remains of wood, nut fragments, and maize fragments. Hickory wood, pine wood, and oak wood occurred in the samples. Both hickory nut and black walnut fragments also were recovered. Furthermore, maize cupules and a glume fragment were identified in the flotation material. The heavy fractions of the flotation samples contained mostly hickory nut fragments, and the charred plant material outweighed the charcoal from the light fractions. Interestingly, two maize cupules, usually a component of the light fraction, were recovered from the heavy fraction of a sample collected from Unit 6 , Feature 1, 20-31 cm.

Four flotation samples were examined from Feature I in Units 5, 6, and 8. These samples contained abundant hickory nut fragments, a black walnut fragment, and three maize cupule fragments. Wood identified from the feature included pine, oak, and hickory. The content of samples examined from Feature 1 did not differ radically from the non-feature samples. Non-feature samples recovered from Unit 5,6,7, and 8 contained pine, oak, hickory, and cottonwood/willow wood charcoal. Maize and hickory nut fragments also were noted in the non-feature samples (Table 24). Maize seems to be concentrated in the upper levels (15-31 cm bs), because the sample recovered from a slightly deeper context $(30-40 \mathrm{~cm}$ bs) contains only hickory nut and wood charcoal.

As noted in Table 25, the macrobotanical samples from the Leaning Rock site contained materials that differed from the content of the flotation samples, including acorn cotyledons and a squash seed. Acorn cotyledons were recovered in levels from $20-40 \mathrm{~cm}$ bs from Units 3 and 4 , as well as Unit 12 in Feature 5. A single sample from Feature 2 contained maize kernels. The squash seed was recovered from Unit 12, in the $40-50 \mathrm{~cm}$ level. 
Table 23. Summary of the additional nine fotation samples from the Leaning Rock site.

\begin{tabular}{|c|c|c|c|c|c|c|c|c|c|c|}
\hline 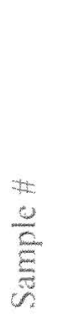 & $\stackrel{\Xi}{\Xi}$ & 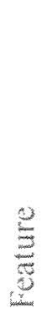 & $\begin{array}{l}\frac{8}{E} \\
\frac{E}{3} \\
\frac{3}{3} \\
\frac{3}{3}\end{array}$ & 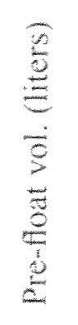 & 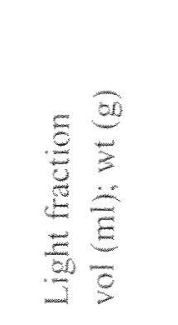 & 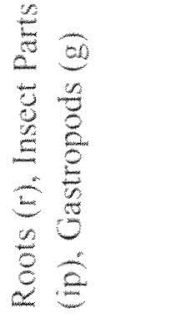 & 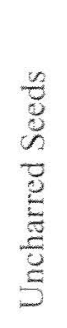 & 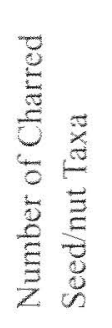 & 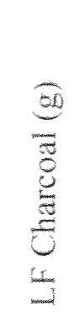 & 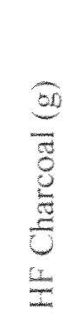 \\
\hline 1 & 5 & 1 & $15-31$ & 5.0 & $4 \mathrm{ml} ; 1.7 \mathrm{~g}$ & $\mathrm{r}++, \mathrm{ip}+$ & 2 & 2 & 0.1 & 0.4 \\
\hline 2 & 5 & 1 & $|5-3|$ & 5.0 & $5 \mathrm{ml} ; 2.9 \mathrm{~g}$ & $r+, g+$ & 0 & 1 & $<.1$ & 0.3 \\
\hline 3 & 5 & 1 & $20-30$ & 5.0 & $7 \mathrm{ml} ; 3.2 \mathrm{~g}$ & $\mathrm{r}+, \mathrm{ip}++$ & 1 & 2 & 0.2 & 0.6 \\
\hline 4 & 5 & - & $20-30$ & 5.0 & $4 \mathrm{ml} ; 1.7 \mathrm{~g}$ & $r+t+$ & 0 & 1 & 0.3 & 0.5 \\
\hline 5 & 6 & - & $20-30$ & 5.0 & $3 \mathrm{ml} ; 9 \mathrm{~g}$ & $r+t$ & 1 & 2 & 0.2 & 0.4 \\
\hline 6 & 6 & 1 & $20-31$ & 5.0 & $3 \mathrm{ml} ; 1.2 \mathrm{~g}$ & $r+$ & 3 & 2 & 0.1 & 0.1 \\
\hline 7 & 8 & 1 & $15-31$ & 5.0 & $3 \mathrm{ml} ; 2.4 \mathrm{~g}$ & $\mathrm{r}+, \mathrm{g}+$ & 0 & 2 & 0.1 & 0.1 \\
\hline 8 & 8 & - & $30-40$ & 5.0 & $4 \mathrm{ml} ; 2.7 \mathrm{~g}$ & $r+$ & 0 & 1 & 0.3 & $<.1$ \\
\hline 9 & 7 & & $20-30$ & 5.0 & $7 \mathrm{ml} ; 2.5 \mathrm{~g}$ & $\mathrm{r}++; g+$ & 1 & 1 & 0.6 & 0.5 \\
\hline
\end{tabular}

Table 24. Plant remains identified from the additional flotation samples, light and heavy fractions.

\begin{tabular}{|c|c|c|c|c|c|c|c|c|c|c|}
\hline Sample & $\begin{array}{l}\text { Light } \\
\text { Heavy } \\
\text { Fraction }\end{array}$ & Unit & Feature & $\begin{array}{l}\text { Level } \\
\text { (cm bs) }\end{array}$ & Taxon & Common & Part & Count & $\begin{array}{l}\text { Vol. } \\
(\mathrm{ml})\end{array}$ & $\begin{array}{l}\mathrm{Wt} \\
(\mathrm{g})\end{array}$ \\
\hline 1 & LF & 5 & I & $15-31$ & Caryasp. & Hickory & Nut & 34 & - & 0.1 \\
\hline 1 & LF & 5 & 1 & $15-31$ & Carya sp. & Hickory & Wood & 10 & $-\cdots$ & $<.1$ \\
\hline 1 & LF & 5 & 1 & $|5-3|$ & Zea mays & Maize & Cupule & 1 & - & $<.1$ \\
\hline 1 & HF & 5 & 1 & $|5-3|$ & Carya sp. & Hickory & Nut & 11 & -- & 0.4 \\
\hline 2 & LF & 5 & 1 & $|5-3|$ & Carya sp. & Hickory & Nut & 11 & - & $<.1$ \\
\hline 2 & LF & 5 & 1 & $|5-3|$ & Carva sp. & Hickory & Wood & 8 & -- & $<.1$ \\
\hline 2 & HF & 5 & 1 & $|5-3|$ & Carya sp. & Hickory & Nut & 5 & -- & 0.3 \\
\hline 3 & $\mathrm{LF}$ & 5 & FS2 & $20-30$ & Caryasp. & Hickory & Nut & 16 & -- & 0.2 \\
\hline 3 & LF & 5 & FS2 & $20-30$ & Indeterminate & NA & Wood & 3 & - & $<.1$ \\
\hline 3 & $L F$ & 5 & FS2 & $20-30$ & Zea mays & Maize & Cupule & 1 & $\ldots$ & $<1$ \\
\hline 3 & $\mathrm{HF}$ & 5 & $\mathrm{FS} 2$ & $20-30$ & Carya sp. & Hickory & Nut & $25+$ & 3 & 0.6 \\
\hline 4 & LF & 5 & - & $20-30$ & Carva sp. & Hickory & Nut & 24 & -- & 0.3 \\
\hline 4 & LF & 5 & - & $20-30$ & Indeterminate & NA & Wood & 12 & - & $<.1$ \\
\hline 4 & HF & 5 & - & $20-30$ & Caryasp. & Hickory & Nut & 20 & $\ldots$ & 0.5 \\
\hline
\end{tabular}


Table 24. (Continued)

\begin{tabular}{|c|c|c|c|c|c|c|c|c|c|c|}
\hline $\begin{array}{c}\text { Sample } \\
\#\end{array}$ & $\begin{array}{l}\text { Light } \\
\text { Heavy } \\
\text { Fraction }\end{array}$ & Unit & Feature & $\begin{array}{l}\text { Level } \\
\text { (cm bs) }\end{array}$ & Taxon & Common & Part & Count & $\begin{array}{l}\text { Vol. } \\
(\mathrm{ml})\end{array}$ & $\begin{array}{l}\text { Wt } \\
\text { (g) }\end{array}$ \\
\hline 5 & LF & 6 & - & $20-30$ & Pinus sp. & Pine & Wood & 2 & $\cdots$ & $<.1$ \\
\hline 5 & LF & 6 & - & $20-30$ & Indeterminate & NA & Wood & 17 & -- & $<.1$ \\
\hline 5 & LF & 6 & - & $20-30$ & Carya sp. & Hickory & Nut & 14 & - & 0.1 \\
\hline 5 & LF & 6 & - & $20-30$ & Zea mavs & Maize & Glume & 1 & -- & $<.1$ \\
\hline 5 & $L F$ & 6 & - & $20-30$ & Zea mays & Maize & Cupule & 1 & -- & $<.1$ \\
\hline 5 & $\mathrm{HF}$ & 6 & - & $20-30$ & Caryasp. & Hickory & Nut & $25+$ & 2 & 0.4 \\
\hline 6 & LF & 6 & 1 & $20-31$ & Pinus sp. & Pine & Wood & 2 & $\cdots$ & $<1$ \\
\hline 6 & LF & 6 & 1 & $20-31$ & Carya sp. & Hickory & Nut & 10 & - & 0.1 \\
\hline 6 & LF & 6 & 1 & $20-31$ & Indeterminate & NA & Wood & 10 & -- & 0.1 \\
\hline 6 & $\mathrm{HF}$ & 6 & 1 & $20-31$ & Zea mays & Maize & Cupule & 2 & $-\infty$ & $<.1$ \\
\hline 6 & HF & 6 & 1 & $20-31$ & Carya sp. & Hickory & Nut & 9 & $=$ & 0.1 \\
\hline 7 & LF & 8 & 1 & $|5-3|$ & Quercus sp. & Oak & Wood & 16 & $\cdots$ & 0.1 \\
\hline 7 & LF & 8 & 1 & $15-31$ & Carya sp. & Hickory & Nut & 13 & - & $<1$ \\
\hline 7 & $\mathrm{HF}$ & 8 & 1 & $15-31$ & Juglans nigra & Black walnut & Nut & 1 & - & $<.1$ \\
\hline 7 & HF & 8 & 1 & $15-31$ & Carya sp. & Hickory & Nut & 7 & - & 0.1 \\
\hline 8 & LF & 8 & - & $30-40$ & Quercus sp. & Oak & Wood & 25 & - & 0.2 \\
\hline 8 & LF & 8 & - & $30-40$ & Carya sp. & Hickory & Nut & 19 & - & 0.1 \\
\hline 8 & HF & 8 & - & $30-40$ & Carya sp. & Hickory & Nut & 14 & - & $<.1$ \\
\hline 9 & & 7 & - & $20-30$ & Salicaceae & $\begin{array}{l}\text { Willow/ } \\
\text { cottonwood }\end{array}$ & $\begin{array}{l}\text { Wood } \\
\text { Wood }\end{array}$ & $\begin{array}{l}25+ \\
25+\end{array}$ & $\begin{array}{l}3 \\
3\end{array}$ & $\begin{array}{l}0.5 \\
0.5\end{array}$ \\
\hline 9 & & 7 & - & $20-30$ & Caryasp. & Hickory & Nut & 9 & - & $<.1$ \\
\hline
\end{tabular}

Table 25. Identification of point- or screen-collected macrobotanical samples.

\begin{tabular}{|lccccccc|}
\hline Unit & Feature & Level $(\mathrm{cm})$ & Taxon & Common & Part & Count & Weight \\
\hline TU-12 & & $20-30$ & Quercus sp. & Oak & Acorn-cotyledon & 1 & 0.1 \\
TU-12 & & $40-50$ & Quercus sp. & Oak & Acorn-cotyledon & 1 & 0.3 \\
TU-12 & & $40-50$ & Cucurbita sp. & Squash & Sced & 1 & $-\ldots$ \\
TU-12 & 5 & $60-70$ & Quercus sp. & Oak & Acorn-cotyledon & 2 & 0.2 \\
TU-12 & & $70-80$ & Indeterminate & NA & Wood & 5 & $<.1$ \\
TU-12 & 5 & $30-40$ & Quercus sp. & Oak & Acorn-cotyledon & 1 & 0.2 \\
TU-3 & & $30-40$ & Quercus sp. & Oak & Acom-cotyledon & 2 & 0.1 \\
TU-4 & & $20-30$ & Quercus sp. & Oak & Acorn-cotyledon & 1 & - \\
& & & & & & & \\
\hline
\end{tabular}




\section{CONCLUSIONS}

Analysis of the first four flotation samples yielded oak and hickory wood, and relatively abundant hickory nut fragments. A single maize cupule fragment was recovered from TU-8. Comparison of two methods of flotation yielded very similar results. The analysis of maize remains $(n=7$ ) showed that 10- and 14 - row cobs were present at the site (Table 26). Estimates of row number were obtained from two other specimens, and these were 8- and 12-row cobs. The cobs from the Leaning Rock site, therefore, exhibited some diversity, but the sample size was very small.

Although maize was not abundant in the current study, it was fairly widespread, occurring in $44.4 \%$ of the nine later flotation samples, but only one cupule fragment was noted in the first four flotation samples. All told, maize is present in $38.5 \%$ of the 13 flotation samples from the Leaning Rock site. Interestingly, the same

Table 26. Description of maize remains.

\begin{tabular}{|c|c|c|c|c|}
\hline Sample \# & $\begin{array}{l}\text { Provenience } \\
(\mathrm{cm} \mathrm{bs})\end{array}$ & Row \# & Part Measured & $\begin{array}{l}\text { Measurement } \\
\qquad(\mathrm{mm})\end{array}$ \\
\hline 1 & TU3, 20-30(1/4") & 10-row & $\begin{array}{l}\text { Cob diameter } \\
\text { Cob length } \\
\text { Cupule width } \\
\text { Cupule width } \\
\text { Cupule width } \\
\text { Cupule width } \\
\text { Cupule length } \\
\text { Cupule length } \\
\text { Cupule length } \\
\text { Cupule length }\end{array}$ & $\begin{array}{l}8.3 \\
19.8 \\
3.6 \\
3.5 \\
3.1 \\
2.9 \\
1.1 \\
1.0 \\
1.2 \\
1.1\end{array}$ \\
\hline 2 & TU3, $30-40\left(1 / 4^{\prime \prime}\right)$ & 14-row & $\begin{array}{l}\text { Cob diameter } \\
\text { Cob length } \\
\text { Cupule width } \\
\text { Cupule width } \\
\text { Cupule width } \\
\text { Cupule width } \\
\text { Cupule length } \\
\text { Cupule length } \\
\text { Cupule length } \\
\text { Cupule length }\end{array}$ & $\begin{array}{c}11.3 \\
\text { Partial cob } \\
3.1 \\
3.6 \\
3.2 \\
3.4 \\
1.0 \\
1.0 \\
1.1 \\
1.1\end{array}$ \\
\hline $2 \mathrm{a}$ & TU3, $30-40\left(1 / 4^{n}\right)$ & 8-row (est.) & $\begin{array}{l}\text { Cob diameter } \\
\text { (Cob segment split } \\
\text { longitudinally in 1/2) } \\
\text { Cupule width } \\
\text { Cupule width } \\
\text { Cupule width } \\
\text { Cupule width } \\
\text { Cupule length } \\
\text { Cupule length } \\
\text { Cupule length } \\
\text { Cupule length }\end{array}$ & $\begin{array}{l}3.1 \\
3.2 \\
3.6 \\
3.4 \\
2.2 \\
1.9 \\
1.8 \\
2.1\end{array}$ \\
\hline
\end{tabular}


Table 26. (Coninued)

\begin{tabular}{|c|c|c|c|c|}
\hline Sample & $\begin{array}{l}\text { Provenience } \\
\text { (cni bs) }\end{array}$ & Row $\#$ & Part Measured & $\begin{array}{l}\text { Measurement } \\
\text { (mm) }\end{array}$ \\
\hline \multirow[t]{9}{*}{$3 a$} & TU4, 30-40 & 12-row (est.) & $\begin{array}{l}\text { Cob diameter } \\
\text { (Cob segment split } \\
\text { longitudinally in } 1 / 2 \text { ) }\end{array}$ & 11.1 \\
\hline & & & Cupule width & 4.0 \\
\hline & & & Cupule width & 3.8 \\
\hline & & & Cupule width & 4.1 \\
\hline & & & Cupule width & 4.0 \\
\hline & & & Cupule length & 1.6 \\
\hline & & & Cupule length & 1.4 \\
\hline & & & Cupule length & 1.8 \\
\hline & & & Cupule length & 1.4 \\
\hline \multirow[t]{2}{*}{$3 b$} & TU $4,30-40$ & No row count- & Cupule width & 6.6 \\
\hline & & too small & Cupule length & 1.8 \\
\hline \multirow[t]{2}{*}{$3 \mathrm{c}$} & TU4, $30-40$ & No row count-- & Cupule width & 5.4 \\
\hline & & too small & Cupule Iength & 1.9 \\
\hline \multirow[t]{2}{*}{$3 d$} & TU4, $30-40$ & No row count-- & Cupule width & 4.9 \\
\hline & & too small & Cupule length & 0.9 \\
\hline
\end{tabular}

site has yielded at least six cob fragments, four of which were large enough to provide row counts. These cobs showed some variety, and included 8-row, 10-row, 12-row and 14-row cobs. The squash seed, identified in a single macrobotanical sample from Unit 12, provided further evidence for plant production.

The fotation and macrobotanical samples also contain evidence for both hickory nut and acorn processing, Hickory nut fragments were both abundant and ubiquitous, which is typical of Caddo sites in East Texas. Acorns are typically under-represented in archeological assemblages (Petruso and Wickens 1984). The presence of charred acorn cotyledons (the meat of the acorn), recovered from at least four different units, suggests that acorns may have been processed in large quantities at the site.

Therefore, the plant remains recovered in the archeological investigations suggest that the Caddo inhabitants of the Leaning Rock site were practicing maize-based agriculture that likely included squash and beans. Several row sizes of maize were utilized, indicating crop diversity. But the economy was decidedly mixed, and the settlement devoted considerable effort to harvesting and processing forest mast, including acorns, hickory nuts, and walnuts. This investment of labor into both plant production and wild plant harvesting is typical of the Caddo economy in historic times, as described by Solis (1931) and Espinosa (Tous 1930). Caddo settlements clearly continued to rely on forest mast and other wild plants even though they cleared and planted fields for at least two forms of maize, early green corn and a late-season flour crop. Although it is impossible to determine the varieties of com from the charred remains from this site, the variety of different cob rows attests to a diverse gene pool in the maize crop. 


\title{
CERAMIC RESIDUE ANALYSIS (PHYTOLITHS AND STARCH) OF A SHERD FROM THE LEANING ROCK SITE (4ISM325), TEXAS
}

\author{
Linda Scott Cummings
}

\section{INTRODUCTION}

A single ceramic sherd recovered from the Leaning Rock site (41SM325) representing a Caddo household in eastern Smith County, Texas, contained charred residue that was examined for phytolith and/or starch evidence of foods that might have been cooked in the vessel. This plain rim sherd appeared to be part of a large jar.

\section{METHODS}

Charred, organic residue recovered from ceramic sherds should represent residue of foods cooked in the vessel. A small ceramic rim sherd and adhering organic residue were cleaned of all visible dirt, then was cleaned using pressurized air to remove any modern contaminants. Following this, the ceramic sherd with organic residue was placed in a $600 \mathrm{ml}$ beaker containing reverse osmosis water and placed in a sonicator to remove as much sediment from the porous residue as possible. Sonication removed some visible fine debris. Using a dental pick, the charred organic residue was removed from two small indentations or score marks along the rim of the ceramic sherd. This charred, organic residue was sieved through 150 -micron mesh to help break it into smaller fragments, then placed in a centrifuge tube. The supernatant was removed by centrifuging and decanting. The charred, organic residue was treated with Schulze solution, a mixture of concentrated nitric acid and potassium chlorate, to which small quantities of concentrated $(35 \%)$ hydrogen peroxide were added. The tube, containing the sample and Schulze solution, were placed in a beaker of hot sand to speed the chemical reaction designed to remove carbonized organic debris. When the reaction appeared to be complete, the tube was removed from the hot sand and centrifuged. The supernatant was decanted and reverse osmosis water was added to rinse the sample. Several reverse osmosis water rinses and centrifuge/decant cycles were completed, then the sample was rinsed with alcohol to prepare it for mounting on a microscope slide. A single microscope slide was made with the residue using a mixture of cinnemaldehyde and canola oil. The sample was examined with a Nikon light microscope at a magnification of 500x. Phytolith diagrams are produced using Tilia, which was developed by Dr. Eric Grimm of the llinois State Museum for diagramming pollen.

\section{DISCUSSION AND CONCLUSIONS}

Midden deposits at a small Caddo household in eastern Smith County, Texas contained numerous pottery sherds and lithic debris. Calibrated radiocarbon ages of AD 1200-1320 and AD 1270-1420 were returned on nutshell from the midden area around a hearth (see Table 3). A plain bone-grog tempered rim sherd measuring $5 \times 8 \mathrm{~cm}$ and approximately $8 \mathrm{~mm}$ thick, was recovered from Unit 1 in level $3(20-30 \mathrm{~cm}$ bs). The bone/grog tempered sherd appears to represent a large jar with burnished surfaces on both the interior and exterior. A heavy residue was noted on the interior of the sherd, so it was submitted to Paleo Research Institute for analysis. After removal of the residue and extraction of any phytoliths and/or starches that might be present, the sample was examined using a light microscope. The phytolith record appears to represent grasses (Figure 44), which are expected as part of the local vegetation. In addition, a single Zea mavs cob-type phytolith was recovered, identifying maize as a food cooked in this large jar. Recovery of the large quantity of grass phytoliths indicates infiltration of 


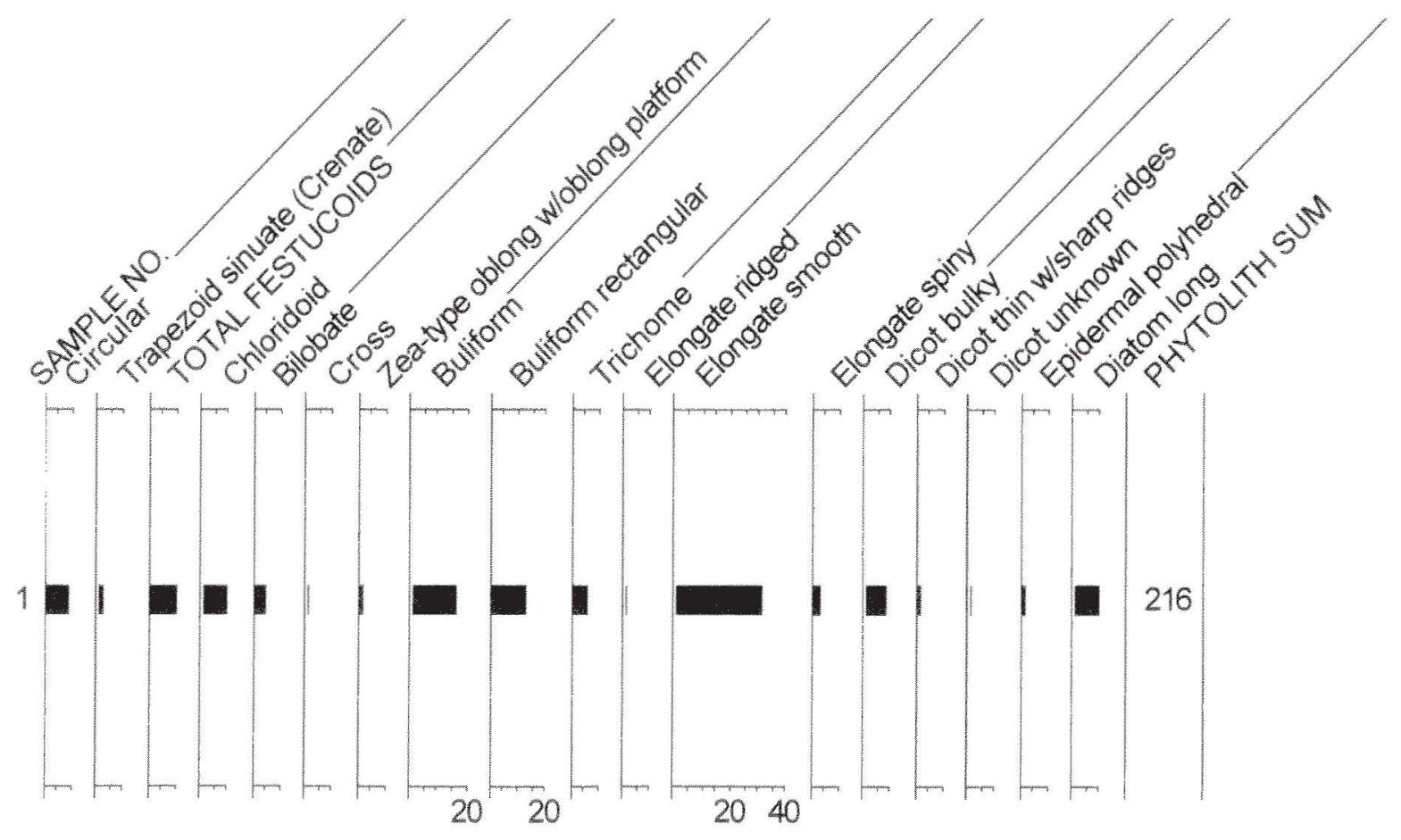

Figure 44. Phytolith diagram from the Leaning Rock site (41SM325).

the porous, charred residue with microscopic remains from the surrounding midden matrix. No starches were observed while examining this sample.

\section{CHARRED NUTSHELL AND WOOD}

The abundance of nutshell indicates that hickory nut processing played an important part in the Caddo subsistence at Leaning Rock. Sixty percent ( $320.5 \mathrm{~g}$ ) of the charred nutshell came from Feature 5 (Table 27). The majority of the remaining charred nutshell and wood charcoal came from $20-40 \mathrm{~cm}$ bs in the midden zone.

Table 27. Charred nutshell and wood by weight.

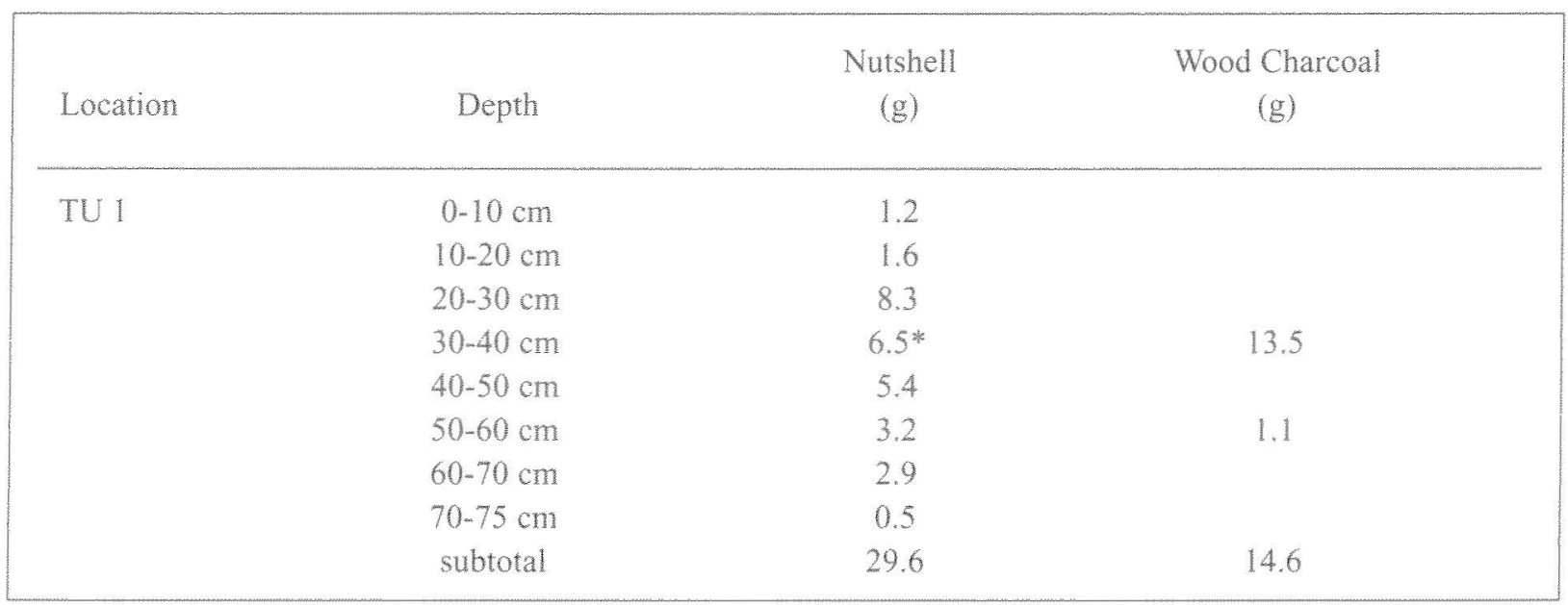


Table 27. (Continued)

\begin{tabular}{|c|c|c|c|}
\hline Location & Depth & $\begin{array}{c}\text { Nutshell } \\
\text { (g) }\end{array}$ & $\begin{array}{c}\text { Wood Charcoal } \\
\text { (g) }\end{array}$ \\
\hline \multirow[t]{3}{*}{ TU 2} & $10-20 \mathrm{~cm}$ & 0.5 & \\
\hline & $20-30 \mathrm{~cm}$ & 2.3 & \\
\hline & subtotal & 2.8 & 0.0 \\
\hline \multirow[t]{5}{*}{ TU 3} & $10-20 \mathrm{~cm}$ & 0.2 & 0.8 \\
\hline & $20-30 \mathrm{~cm}$ & 0.9 & 0.5 \\
\hline & $30-40 \mathrm{~cm}$ & $6.3^{*}$ & 2.1 \\
\hline & $40-50 \mathrm{~cm}$ & 2.6 & 1.2 \\
\hline & subtotal & 10.0 & 4.6 \\
\hline \multirow[t]{5}{*}{ TU 4} & $10-20 \mathrm{~cm}$ & 0.8 & \\
\hline & $20-30 \mathrm{~cm}$ & 5.7 & 1.8 \\
\hline & $30-40 \mathrm{~cm}$ & 6.1 & 3.0 \\
\hline & $40-50 \mathrm{~cm}$ & 3.3 & 4.8 \\
\hline & subtotal & 15.9 & 9.6 \\
\hline \multirow[t]{5}{*}{ TUS } & $10-20 \mathrm{~cm}$ & 0.3 & \\
\hline & $20-30 \mathrm{~cm}$ & 0.6 & 0.3 \\
\hline & $30-40 \mathrm{~cm}$ & 2.8 & \\
\hline & $40-60 \mathrm{~cm}$ & 1.2 & \\
\hline & subtotal & 4.9 & 0.3 \\
\hline \multirow[t]{5}{*}{ TU 6} & $0-10 \mathrm{~cm}$ & 0.1 & \\
\hline & $10-20 \mathrm{~cm}$ & 0.7 & \\
\hline & $20-30 \mathrm{~cm}$ & 1.7 & \\
\hline & $30-40 \mathrm{~cm}$ & 1.8 & 1.9 \\
\hline & subtotal & 12.9 & 1.9 \\
\hline \multirow[t]{4}{*}{ TU 7} & $10-20 \mathrm{~cm}$ & 1.5 & 0.4 \\
\hline & $20-30 \mathrm{~cm}$ & 3.2 & 1.1 \\
\hline & $30-40 \mathrm{~cm}$ & 4.0 & 0.8 \\
\hline & subtotal & 8.7 & 2.3 \\
\hline \multirow[t]{3}{*}{ TU 8} & $20-30 \mathrm{~cm}$ & 1.6 & \\
\hline & $30-40 \mathrm{~cm}$ & 1.8 & \\
\hline & subtotal & 3.4 & 0.0 \\
\hline \multirow[t]{4}{*}{ TU 9} & $10-20 \mathrm{~cm}$ & 0.3 & \\
\hline & $20-30 \mathrm{~cm}$ & 1.4 & 28.3 \\
\hline & $30-40 \mathrm{~cm}$ & 4.5 & 60.0 \\
\hline & subtotal & 6.2 & 88.3 \\
\hline
\end{tabular}


Table 27. (Continued)

\begin{tabular}{|c|c|c|c|}
\hline Location & Depth & $\begin{array}{l}\text { Nutshell } \\
\text { (g) }\end{array}$ & $\begin{array}{l}\text { Wood Charcoal } \\
\text { (g) }\end{array}$ \\
\hline \multirow[t]{5}{*}{ TU 10} & $10-20 \mathrm{~cm}$ & & 1.4 \\
\hline & $20-30 \mathrm{~cm}$ & 1.2 & 1.2 \\
\hline & $30-40 \mathrm{~cm}$ & 1.4 & 1.7 \\
\hline & $40-50 \mathrm{~cm}$ & 1.9 & 1.8 \\
\hline & subtotal & 4.5 & 6.1 \\
\hline \multirow[t]{4}{*}{ TU 11} & $10-20 \mathrm{~cm}$ & 0.5 & 5.0 \\
\hline & $20-30 \mathrm{~cm}$ & 0.9 & 6.5 \\
\hline & $30-40 \mathrm{~cm}$ & 2.4 & 33.9 \\
\hline & subtotal & 3.8 & 45.4 \\
\hline \multirow[t]{6}{*}{ TU 12} & $0-10 \mathrm{~cm}$ & 0.3 & \\
\hline & $10-20 \mathrm{~cm}$ & 2.2 & \\
\hline & $20-30 \mathrm{~cm}$ & 26.4 & 3.3 \\
\hline & $30-40 \mathrm{~cm}$ & 20.5 & 4.9 \\
\hline & $40-50 \mathrm{~cm}$ & 46.9 & 1.0 \\
\hline & subtotal & 96.3 & 9.2 \\
\hline \multirow[t]{4}{*}{ TU 13} & $10-20 \mathrm{~cm}$ & 1.1 & \\
\hline & $20-30 \mathrm{~cm}$ & 1.0 & \\
\hline & $30-40 \mathrm{~cm}$ & 3.5 & \\
\hline & subtotal & 5.6 & \\
\hline Fea. 2 & $30-44 \mathrm{~cm}$ & 8.6 & \\
\hline Fea. 3 & $50-88 \mathrm{~cm}$ & 2.0 & 2.0 \\
\hline Fea. 4 & $50-77 \mathrm{~cm}$ & 0.1 & \\
\hline Fea. 5 & $50-60 \mathrm{~cm}$ & $47.8^{*}$ & 10.4 \\
\hline Fea. 5 & $60-70 \mathrm{~cm}$ & 80.8 & 3.7 \\
\hline Fea. 5 & $65-75 \mathrm{~cm}$ & 19.7 & 10.3 \\
\hline Fea. 5 & $75-85 \mathrm{~cm}$ & 19.7 & 2.7 \\
\hline Fea. 5 & $70-80 \mathrm{~cm}$ & 76.1 & 7.3 \\
\hline Fea. 5 & $80-90 \mathrm{~cm}$ & 48.8 & \\
\hline Fea. 5 & $90-100 \mathrm{~cm}$ & 13.0 & 1.4 \\
\hline Fea. 5 & $100-107 \mathrm{~cm}$ & 11.0 & 1.6 \\
\hline \multirow[t]{2}{*}{ Fea. 6} & $55-75 \mathrm{~cm}$ & 0.4 & \\
\hline & Subtotal & 328.0 & 39.4 \\
\hline \multirow[t]{3}{*}{ STI } & $20-40 \mathrm{~m}$ & 0.1 & \\
\hline & $40-60 \mathrm{~cm}$ & 0.2 & \\
\hline & subtotal & 0.3 & 0.0 \\
\hline \multirow[t]{2}{*}{ ST 2} & $0.20 \mathrm{~cm}$ & 1.7 & \\
\hline & subtotal & 1.7 & 0.0 \\
\hline
\end{tabular}


Table 27. (Continued)

\begin{tabular}{|c|c|c|c|}
\hline Location & Depth & $\begin{array}{l}\text { Nutshell } \\
\text { (g) }\end{array}$ & $\begin{array}{c}\text { Wood Charcoal } \\
\text { (g) }\end{array}$ \\
\hline ST 3 & $\begin{array}{l}20-40 \mathrm{~cm} \\
\text { subtotal }\end{array}$ & $\begin{array}{l}0.9 \\
0.9\end{array}$ & 0.0 \\
\hline ST 4 & $\begin{array}{c}0-20 \mathrm{~cm} \\
20-40 \mathrm{~cm} \\
\text { subtotal }\end{array}$ & $\begin{array}{l}0.5 \\
0.7 \\
1.2\end{array}$ & 0.0 \\
\hline ST 5 & $\begin{array}{l}20-40 \mathrm{~cm} \\
\text { subtotal }\end{array}$ & $\begin{array}{l}1.7 \\
1.7\end{array}$ & 0.0 \\
\hline Totals & & 533.9 & 221.7 \\
\hline
\end{tabular}

\section{LEANING ROCK SITE (41SM325) FAUNAL ANALYSIS}

\section{LeeAnna Schniebs \\ INTRODUCTION}

Investigations at the Leaning Rock site (41SM325), a Middle Caddo period habitation site/farmstead in eastern Smith County, Texas, yielded a total of 4,592 faunal specimens (weighing 2,215 grams). Because of budgetary considerations, unidentifiable bone fragments were consolidated into one miscellaneous category, comprised mostly of large bird and small, medium, and large mammal remains. These pieces were counted and weighed only, and will not be discussed further. This was done so as to not minimize the importance of the unidentifiable bones.

Approximately $16 \%$ of the assemblage ( $\mathrm{n}=712,853.32$ grams) was identified to the taxonomic level of class or lower (family, genus, or species). Identifiable bones were recovered from six surface collection units, two shovel tests, and 13 hand-excavated units, including four features. Depths range from the modern ground surface to 107 centimeters below surface ( $\mathrm{cm}$ bs).

\section{METHODS}

Standard zooarcheological methods have been used. Attributes of the identifiable pieces consist of taxon, element and portion of that element, anatomical location of the element, any notes on age, burning, and presence of modification if applicable. Provenience information was also recorded. The prehistoric vertebrate remains were inventoried using Excel 5.0 to manipulate the generated data. An Ohaus digital scale, Model CT600-S, 
was used to record bone weight. Identifications were made to the most specific category possible depending on condition of the bone and available comparative material. Only positive identifications resulted in the assignment of elements to genus or species.

Quantification of the assemblage is summarized as number of identified specimens per taxon (NISP) and as minimum number of individuals (MNI) for identified elements. The minimum numbers method was chosen as the most suitable analytical measure of abundance. "It involves no hypotheses and is purely factual. The minimum number of animals that the bones could have come from is an indisputable fact" (Chaplin 1971:69-70).

MNI estimates were calculated according to the most frequently occurring element, based on symmetry and element portion (Munzel 1986). In the mammalian class, teeth are usually used whenever possible. Teeth retained in socket were recorded but not counted or weighed. Loose teeth (those not in socket) were counted and weighed as separate elements. This allows for MNI calculations without elevating specimen counts or skewing the data. However, post-cranial elements were used in this site collection. In some cases, the presence of a single element constituted an MNI of one.

\section{RESULTS}

The following section describes the preferred habitat and provenience for all of the identifiable vertebrate taxa recovered from the Leaning Rock site. All vertebrate classes are represented, but mammals dominate the identifiable faunal sample. Number of identified specimens (NISP), minimum number of individuals (MNI), and weights for each taxon are summarized in Table 28.

Table 28. Identifable Faunal Specimens from the Leaning Rock Site (41SM325) by Provenience.

\begin{tabular}{|c|c|c|c|c|c|c|c|c|c|c|c|}
\hline TU & Depth & Feat & Qty & Taxon & Elem/Por & Side & Age & Burn & Mod & Wtig & Comments \\
\hline 1 & Otolo & & 1 & deer & mtpod shft frg & & & $b$ & & 0.6 & \\
\hline 1 & Otolo & & 1 & turtle & carapace frg & & & not & & 0.2 & \\
\hline 1 & $10 t 020$ & & 1 & deer & mtpod prox frg & & & $\mathrm{b}$ & & 2.2 & \\
\hline 1 & $10 t 020$ & & 1 & turtle & shell frg & & & $b$ & & 0.2 & \\
\hline 1 & 15 to 24 & & 1 & deer & diastema & $\mathrm{R}$ & & not & & 3.5 & FS \\
\hline 1 & $15 t 024$ & & I & deer & mtpod shft frg & & & $b$ & & 0.5 & $\mathrm{FS}$ \\
\hline 1 & $15 t 024$ & & 1 & kinostemidae & carapace frg & & & not & & 0.1 & FS \\
\hline 1 & $15 t 024$ & & 3 & turtle & shell ftg & & & $b$ & & 0.3 & FS \\
\hline 1 & $20 t 030$ & & 1 & colubridaes & vertebra & $\mathrm{A}$ & & not & & 0.2 & \\
\hline 1 & 201030 & & 1 & deer & vert facet & & & $b$ & & 0.9 & \\
\hline 1 & $20 t 030$ & & 1 & deer & mtpod dist condyle & & & not & & 3 & \\
\hline 1 & 201030 & & 3 & deer & mtpod shnt frg & & & $b$ & & 1 & \\
\hline 1 & 20 to 30 & & 1 & deer & mtpod shet frg & & & not & & 1.4 & \\
\hline 1 & $20 t 030$ & & 1 & deer & antler mg & & & $b$ & & 1.5 & \\
\hline 1 & $20 t 030$ & & 1 & deer & sesamoid & & & $b$ & & 0.2 & \\
\hline 1 & $20 t 030$ & & 1 & med bird & phx & & & $b$ & & 0.2 & \\
\hline 1 & 20 to 30 & & 1 & squirrel & fem hexd & $L$ & & not & & 0.2 & \\
\hline
\end{tabular}


Table 28. (Continued)

\begin{tabular}{|c|c|c|c|c|c|c|c|c|c|c|c|}
\hline TU & Depth & Feat & Qty & Taxon & Elem:Por & Side & Age & Burn & Mod & Wig & Comments \\
\hline 1 & $20 \operatorname{to} 30$ & & 7 & turtle & shell frg & & & $b$ & & 1.3 & \\
\hline 1 & $20 t 030$ & & 1 & turtle & shell frg & & & not & & 0.1 & \\
\hline 1 & $24 t 033$ & & 1 & pock goph & phx & & & $b$ & & 0.01 & FS \\
\hline 1 & $24 t 033$ & & 1 & squirel & ulna prox & $\mathrm{R}$ & & not & & 0.1 & FS \\
\hline 1 & $24 t 033$ & & 3 & turtle & shell frg & & & $b$ & & 0.3 & FS \\
\hline 1 & $30 t 040$ & & 1 & box & hypo frg & $\mathrm{L}$ & & $b$ & & 0.6 & \\
\hline 1 & $30 t 040$ & & 1 & deer & scap & R & & not & & 23.3 & \\
\hline 1 & $30 t 040$ & & 3 & deer & scap frg & & & not & & 4 & \\
\hline 1 & $30 t 040$ & & 1 & deer & mtpod shft frg & & & not & & 0.7 & \\
\hline 1 & 30 to 40 & & 1 & deer & antler frg & & & $b$ & & 1.2 & \\
\hline 1 & 30 to 40 & & 1 & $\lg \operatorname{mam}$ & 1.b.frag & & & not & blunt & 1.1 & \\
\hline 1 & 30 to40 & & 1 & squirrel & hum dist & R & & not & & 0.4 & \\
\hline 1 & 30 to40 & & 1 & swamp & tooth upper & & & not & & 0.2 & \\
\hline 1 & 30 to40 & & 1 & turkey & hum shft & L & & not & & 27.2 & \\
\hline 1 & 30 to 40 & & 6 & turtle & shell frg & & & $b$ & & 1.4 & \\
\hline 1 & $36 t 040$ & & 1 & pock goph & phx & & & $b$ & & 0.01 & FS \\
\hline 1 & $40 t 050$ & & 1 & box & coracoid & & & not & & 0.1 & \\
\hline 1 & 40 to50 & & 2 & box & carapace frg & & & $\mathrm{b}$ & & 0.4 & \\
\hline 1 & 40 to50 & & 1 & box & peripheral & & & b & & 0.3 & \\
\hline 1 & 40 to 50 & & 1 & ctail & sternibrae frg & $\mathrm{A}$ & & not & & 0.1 & \\
\hline 1 & 40 to50 & & 1 & deer & paradigit & & $\mathrm{mm}$ & not & aw! & 0.7 & broken \\
\hline & & & & & & & & \multicolumn{3}{|c|}{ "exped tool" 0.7} & polish \\
\hline 1 & 40 tos0 & & 3 & deer & antler frg & & & $b$ & & 1.8 & \\
\hline 1 & 40 to50 & & 1 & deer & paradigit & & & not & & 0.5 & \\
\hline 1 & 40 to50 & & 1 & deer & patella frg & $\mathrm{R}$ & & $b$ & & 2.2 & \\
\hline 1 & 40 to50 & & 1 & deer & podial frg & & & $b$ & & 0.9 & \\
\hline 1 & 40 to50 & & 5 & turtle & shell fig & & & $b$ & & 0.8 & \\
\hline 1 & $40+050$ & & 1 & turtle & phx & & & b & & 0.2 & $\begin{array}{l}\text { very lg. } \\
\text { individual }\end{array}$ \\
\hline 1 & $50 t 060$ & & 1 & deer & vert facet & & & b & & 0.7 & \\
\hline 1 & 50 to60 & & 2 & deer & mtpod shft frg & & & b & & 1.4 & \\
\hline 1 & 50 to60 & & 1 & deer & antler frg & & & b & & 0.6 & \\
\hline 1 & 50 to60 & & 1 & deer & lunate & $\mathrm{R}$ & & $b$ & & 1.4 & \\
\hline 1 & 50 to60 & & 1 & swamp & nasal & R & & not & & 0.2 & \\
\hline 1 & $60 t 070$ & & 1 & box & shell frg & & & $b$ & & 0.5 & \\
\hline 1 & 60 to 70 & & 1 & deer & antler frg & & & $b$ & & 0.5 & \\
\hline 1 & 601070 & & 2 & Ig bird & eggshell & & & not & & 0.1 & \\
\hline 1 & 601070 & & 4 & turtle & shell fry & & & $b$ & & 0.5 & \\
\hline 1 & 70075 & & 1 & deer & antler frg & & & $b$ & & 0.6 & \\
\hline 1 & 70075 & & 1 & kinostemidae & pleural frg & & & b & & 0.1 & \\
\hline 1 & 70 to 75 & & 1 & turte & shell frg & & & $b$ & & 0.2 & cf box \\
\hline 2 & Otolo & & 1 & box & plastron frg & & & b & & 0.1 & \\
\hline 2 & Otolo & & 1 & deer & fem shft frg & & & not & & 1.4 & \\
\hline 2 & Otolo & & 1 & deer & antler frg & & & $\mathrm{b}$ & & 0.2 & \\
\hline 2 & 10 to20 & & 1 & box & peripheral frg & & & b & & 0.4 & \\
\hline
\end{tabular}


Table 28. (Continued)

\begin{tabular}{|c|c|c|c|c|c|c|c|c|c|c|c|}
\hline TU & Depth & Feat & Qty & Taxon & Elem/Por & Side & Age & Bum & Mod & Wtg & Comments \\
\hline 2 & $10 t 020$ & & 1 & box & plastron frg & & & $b$ & & 0.1 & \\
\hline 2 & 10 to20 & & 1 & deer & mtpod shft frge & & & $b$ & & 0.7 & \\
\hline 2 & 101020 & & 1 & deer & tooth frg & & & not & & 0.3 & \\
\hline 2 & $20 \mathrm{to} 30$ & & 1 & box & hyo frg & $\mathrm{R}$ & & $b$ & & 0.4 & \\
\hline 2 & $20 t 030$ & & 2 & box & plastron frg & & & b & & 0.4 & \\
\hline 2 & $20 t 030$ & & 3 & deer & mtpod shft frg & & & b & & 1.5 & \\
\hline 2 & 20 to30 & & 1 & turtle & carapace frg & & & not & & 0.3 & \\
\hline 3 & Otolo & & 1 & deer & mtpod shft frg & & & $b$ & & 0.2 & \\
\hline 3 & 10 to20 & & 1 & box & plastron frg & & & b & & 0.2 & \\
\hline 3 & 101020 & & 2 & deer & mtpod shft frg & & & b & & 1.2 & \\
\hline 3 & $20 \operatorname{to} 30$ & & 1 & box & hypo frg & $\mathrm{R}$ & & b & & 0.7 & \\
\hline 3 & 201030 & & 1 & box & nuchal frg & A & & b & & 0.3 & \\
\hline 3 & 20 to 30 & & 1 & bos & peripheral frg & & & $b$ & & 0.5 & \\
\hline 3 & 20 to 30 & & 1 & box & pleural frg & & & not & & 0.3 & \\
\hline 3 & 20 to 30 & & 1 & deer & mtpod shff frg & & & $b$ & & 0.7 & \\
\hline 3 & 20 to 30 & & 1 & deer & rad prox frg & $\mathrm{R}$ & & b & & 2.2 & \\
\hline 3 & $20 t 030$ & & 3 & deer & antler frg & & & $b$ & & 7.5 & \\
\hline 3 & $20 t 030$ & & 1 & deer & sesamoid & & & b & & 0.3 & \\
\hline 3 & $20 t 030$ & & 1 & kinosternidae & peripheral frg & & & $\mathrm{b}$ & & 0.1 & \\
\hline 3 & $20 t 030$ & & 1 & sm bird & l.b.frag & & & not & & 0.1 & \\
\hline 3 & 20 to 30 & & 1 & turtle & shell frg & & & $b$ & & 0.3 & \\
\hline 3 & 20 to 30 & & 2 & turile & shell frg & & & not & & 0.8 & f box \\
\hline 3 & 30 to 40 & & 1 & deer & hum shft frg & $\mathrm{L}$ & & not & & 7 & \\
\hline 3 & 30 to 40 & & 1 & deer & tib shft frg & & & $b$ & & 4.1 & \\
\hline 3 & $30 t 040$ & & 1 & turkey & phx & & & b & & 0.2 & \\
\hline 3 & 30 to 40 & & 8 & turtle & shell frg & & & $b$ & & 1.3 & \\
\hline 3 & 40 toso & & 1 & deer & mtpod shft frg & & & not & & 1 & \\
\hline 3 & 40 to50 & & 1 & turkey & tmt dist med frg & $\mathrm{R}$ & & $b$ & & 0.3 & \\
\hline 3 & 40 to50 & & 1 & turtle & shell frg & & & $b$ & & 0.1 & \\
\hline 4 & 0 tolo & & 1 & box & shell frg & & & not & & 0.8 & \\
\hline 4 & $10 t 020$ & & 1 & deer & tooth frg & & & not & & 0.3 & \\
\hline 4 & 101020 & & 1 & turtle & shell frg & & & $\mathrm{b}$ & & 0.2 & \\
\hline 4 & $20 t 030$ & & 1 & box & neural frg & A & & not & & 1.3 & \\
\hline 4 & $20 \operatorname{to} 30$ & & 1 & deer & scap head & $L$ & & not & & 20.9 & \\
\hline 4 & $20 t 030$ & & 1 & deer & rad shft frg & & & $b$ & & 1.4 & \\
\hline 4 & $20 t 030$ & & 1 & turkey & hum shft frg & & & not & & 1.5 & \\
\hline 4 & 20 to 30 & & 5 & turte & shell frg & & & $b$ & & 0.7 & \\
\hline 4 & $30 t 040$ & & 1 & box & plastron frg & & & $b$ & & 0.2 & \\
\hline 4 & 301040 & & 1 & deer & rad shoft frg & & & $b$ & & 0.4 & \\
\hline 4 & 301040 & & 1 & deer & astrag med frg & L & & $b$ & & 0.8 & \\
\hline 4 & 301040 & & 1 & deer & cuneiform frg & $R$ & & $b$ & & 0.8 & \\
\hline 4 & 306040 & & 1 & deer & mtpod shft frg & & & not & & 4.3 & \\
\hline 4 & 30 to 40 & & 2 & turtle & shell frg & & & $b$ & & 0.5 & \\
\hline 4 & $40 w 50$ & & 1 & deer & vert centrum & $\mathrm{A}$ & & b & & 5 & \\
\hline 4 & $40 t 050$ & & 1 & deer & mtpod shft frg & & & $b$ & & 0.3 & \\
\hline
\end{tabular}


Table 28. (Continued)

\begin{tabular}{|c|c|c|c|c|c|c|c|c|c|c|c|}
\hline TL: & Depth & Feat & Qty & Taxon & Elempor & Side & Age & Burn & Mod & Wtg & Conments \\
\hline 4 & 40 to 50 & & 1 & deer & una shtt fre & & & $b$ & & 0.6 & \\
\hline 4 & 40 to50 & & 1 & deer & antler frg & & & $b$ & & 0.6 & \\
\hline 4 & 401050 & & 1 & squirtel & atlas & A & & not & & 0.1 & \\
\hline 4 & $40 t 050$ & & 1 & turtle & shell frg & & & $b$ & & 0.1 & \\
\hline 5 & $10+020$ & & 1 & box & carapace frg & & & not & & 0.3 & \\
\hline 5 & 20 to 30 & & 2 & deer & mtpod shft frg & & & not & & 2.3 & \\
\hline 5 & $20 t 030$ & & 1 & deer & phx frg & & & b & & 0.2 & \\
\hline 5 & 20 to 30 & & 2 & turtle & shell frg & & & $b$ & & 0.2 & \\
\hline 5 & $30 t 040$ & & 1 & deer & mtpod prox trg & & & b & & 1.2 & \\
\hline 5 & 30 to 40 & & 1 & deer & unar facet & $\mathrm{R}$ & & $b$ & & 2.6 & \\
\hline 5 & $30 t 040$ & & 1 & turtle & shell frg & & & $b$ & & 0.1 & \\
\hline 5 & $31 t 040$ & & 1 & deer & mtpod shft frg & & & not & & 0.5 & below $\mathrm{Fl}$ \\
\hline 6 & 23 & & 1 & deer & astragalus & $\mathrm{R}$ & & $\mathrm{b}$ & & 10.2 & pp7 \\
\hline 6 & 10 to 20 & & 1 & deer & M3 lo & $\mathrm{R}$ & $5 ?$ & not & & 2.4 & \\
\hline 6 & $10 t 020$ & & 1 & turtle & shell frg & & & $b$ & & 0.1 & \\
\hline 6 & $20 t 030$ & & 1 & deer & M3 lo frg & $L$ & & not & & 2.5 & \\
\hline 6 & $20 t 030$ & & 2 & turtle & shell frg & & & $b$ & & 0.4 & \\
\hline 6 & 30 to 40 & & 1 & box & carapace frg & & & $b$ & & 0.4 & \\
\hline 6 & 30 to 40 & & 1 & ctail & fem shft frg & $L$ & & not & & 1.2 & \\
\hline 6 & 30 to 40 & & 1 & deer & mand condyle & $L$ & & not & & 1.9 & \\
\hline 6 & 30 to 40 & & 1 & swamp & Mt4 prox & $\mathrm{R}$ & & not & & 0.1 & \\
\hline 6 & $30 t 040$ & & 1 & turkey & sternum frg & & & not & & 1.4 & \\
\hline 7 & 0 to 10 & & 1 & deer & mtpod shft frg & & & $b$ & & 0.3 & \\
\hline 7 & 10 to 20 & & 1 & box & nuchal frg & $A$ & & b & & 0.2 & \\
\hline 7 & $10 t 020$ & & 3 & deer & intpod shft frg & & & b & & 3.1 & \\
\hline 7 & 10 to 20 & & 1 & rabbit & fem frg & $\mathrm{R}$ & & b & & 0.1 & \\
\hline 7 & $10 t 020$ & & 2 & turtle & shell frg & & & $\mathrm{b}$ & & 0.2 & \\
\hline 7 & $20 t 030$ & & 1 & deer & vert facet & & & not & & 1.5 & \\
\hline 7 & $20 \operatorname{to} 30$ & & 1 & deer & tib shft frg & & & $b$ & & 0.7 & \\
\hline 7 & 30 to 40 & & 1 & box & plastron frg & & & not & & 0.3 & \\
\hline 7 & 30 to 40 & & 0 & ctail & PM3 lo & $L$ & & not & & 0 & \\
\hline 7 & $30 t 040$ & & 1 & ctail & mand frg & $L$ & & not & & 0.4 & \\
\hline 7 & $30 \mathrm{to} 40$ & & 1 & deer & tib dist frg & $L$ & & $b$ & & 1.6 & \\
\hline 7 & 301040 & & I & deer & ulnar notch frg & & & b & & 0.3 & \\
\hline 7 & 30 to 40 & & $\xi$ & deer & antler frg & & & $b$ & & 0.7 & \\
\hline$?$ & 301040 & & I & deer & astragalus & $L$ & & not & & 9.7 & \\
\hline$?$ & 301040 & & 1 & opossum & palatine & $A$ & & not & & 1.5 & \\
\hline 8 & Otolo & & 1 & deer & mtpod shfl frg & & & $b$ & & 0.6 & \\
\hline 8 & $10 t 020$ & & 1 & deer & introd shfitrg & & & $b$ & & 29 & \\
\hline 8 & 201030 & & 2 & box & peripheral & & & not & & 1.5 & \\
\hline 8 & $20 t 030$ & & 1 & ctail & scap head & $L$ & & $b$ & & 0.3 & \\
\hline 8 & 201030 & & 1 & deer & paradigit & & & not & $a w l$ & 0.3 & $\begin{array}{l}\text { polish } \\
\text { "exped } \\
\text { too" }\end{array}$ \\
\hline 8 & $20 t 030$ & & 1 & deer & antler fry & & & $b$ & & 0.6 & \\
\hline
\end{tabular}


Table 28. (Continued)

\begin{tabular}{|c|c|c|c|c|c|c|c|c|c|c|c|}
\hline TU: & Depth & Feat & Qty & Taxon & Elempor & Side & Age & Bum & Mod & Wtg & Comments \\
\hline 8 & 201030 & & 2 & deer & tooth frg & & & not & & 0.9 & \\
\hline 8 & 20 to 30 & & 1 & lgbird & phx & & & not & & 0.3 & \\
\hline 8 & $20 t 030$ & & 3 & mrtle & shell frg & & & $b$ & & 0.7 & \\
\hline 8 & 301040 & & 1 & deer & vert facet & & & $b$ & & 1.3 & \\
\hline 8 & 306040 & & 1 & deer & metpot dist condyle frg & & & $b$ & & 0.8 & \\
\hline 8 & 301040 & & 1 & dear & mipod prox frg & & & not & & 1.7 & \\
\hline 8 & $30 t 040$ & & 1 & dear & Ml up & L & 5yrs & not & & 29 & \\
\hline 9 & 0 tolo & & 1 & wrtle & shell frg & & & $b$ & & 0.3 & \\
\hline 9 & 101020 & & 1 & box & peripheral frg & & & $b$ & & 0.5 & \\
\hline 9 & $10 t 020$ & & 3 & deer & mipod shtt frg & & & b & & 1.2 & \\
\hline 9 & 10 to 20 & & I & deer & antler frg & & & $b$ & & 0.8 & \\
\hline 9 & 10 to 20 & & 1 & deer & tooth frg & & $\mathrm{imm}$ & not & & 0.4 & broken \\
\hline 9 & 10 to20 & & 1 & swamp & mand frg & R & & not & & 1.5 & in 2 frgs \\
\hline 9 & 10 to 20 & & 2 & turtle & shell frg & & & $b$ & & 0.4 & \\
\hline 9 & $20 t 030$ & & 1 & etail & scap neck & L & & $b$ & & 0.2 & \\
\hline 9 & 201030 & & 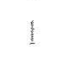 & deer & vert facet & & & $b$ & & 0.4 & \\
\hline 9 & $20 t 030$ & & 1 & deer & palatine frg & $A$ & & $b$ & & 1.2 & \\
\hline 9 & 20 to 30 & & 2 & deer & mipod dist condyle frg & & & $b$ & & 1.2 & \\
\hline 9 & $20 t 030$ & & 3 & deer & mpod shft frg & & & $b$ & & 2.4 & \\
\hline 9 & $20 t 030$ & & 4 & deer & mipod shft frg & & & not & & 7.6 & \\
\hline 9 & 201030 & & 5 & deer & anter frg & & & b & & 1.5 & \\
\hline 9 & $20 t 030$ & & 1 & deer & sesamoid frg & & & not & & 0.2 & \\
\hline 9 & 20 to 30 & & 1 & deer & tooth frg & & $\mathrm{imm}$ & not & & 0.4 & \\
\hline 9 & 20 to 30 & & 1 & deer & tooth frg & & & not & & 0.3 & \\
\hline 9 & 20 to 30 & & 1 & rabbit & rib head & & & not & & 0.1 & \\
\hline 9 & $20 t 030$ & & 1 & turtle & shell frg & & & not & disk & 0.5 & $\begin{array}{l}\text { gnawt } \\
\text { polish }\end{array}$ \\
\hline 9 & 201030 & & 6 & turtle & shell frg & & & $b$ & & 1.2 & \\
\hline 9 & $30 t 040$ & & 1 & box & peripheral frg & & & not & & 0.4 & \\
\hline 9 & $30 t 040$ & & 1 & deer & mtpod shft frg & & & not & blunt & 5.3 & \\
\hline 9 & $30 t 040$ & & 1 & deer & rib frg & & & not & & 2.5 & \\
\hline 9 & $30 t 040$ & & 1 & deer & rib head & & & b & & 0.8 & \\
\hline 9 & $30 t 040$ & & 1 & deer & scap head & $\mathrm{R}$ & & $b$ & & 16.8 & \\
\hline 9 & $30 t 040$ & & 1 & deer & squamosal frg & $\mathrm{R}$ & & not & & 1.6 & sm indiv \\
\hline 9 & 30 to 40 & & 1 & deer & fem shit frg & & & $b$ & & 0.8 & muscle \\
\hline & & & & & & & & & & & scar \\
\hline 9 & $30 t 040$ & & 1 & deer & hum shft lig & $\mathrm{R}$ & & not & & 32 & \\
\hline 9 & $30 t 040$ & & 2 & deer & mipod shft frg & & & $b$ & & 2.7 & \\
\hline 9 & 301040 & & 2 & deer & mpod shft irg & & & not & & 6 & \\
\hline 9 & 301040 & & 1 & deer & metar prox frg & & & not & & 4.3 & \\
\hline 9 & $30 t 040$ & & 1 & text & calcaneus & $L$ & & not & & 17.2 & $\begin{array}{l}\text { minus dist } \\
\text { frg }\end{array}$ \\
\hline 9 & $30 t 040$ & & 1 & sn bird & tht dist & $L$ & & not & & 0.2 & $\begin{array}{c}\text { meadow } \\
\text { lark }\end{array}$ \\
\hline 9) & 301040 & & 1 & squirrel & calcaneus & $L$ & & not & & 0.2 & \\
\hline
\end{tabular}


Table 28. (Contmued)

\begin{tabular}{|c|c|c|c|c|c|c|c|c|c|c|c|}
\hline TU & Depth & Feat & Qty & Taxon & Elem/Por & Side & Age & Burn & Mod & Whig & Comments \\
\hline 9 & 30 to 40 & & 1 & turkey & tbt shet frg & $\mathrm{R}$ & & not & & 0.9 & \\
\hline 9 & $30 t 040$ & & 1 & turtle & shell frg & & & $b$ & & 0.1 & \\
\hline 9 & $30 \operatorname{to} 40$ & & 1 & turtle & shell frg & & & not & & 0.2 & \\
\hline 10 & 0 tolo & & 1 & deer & mtpod shft frg & & & $\mathrm{b}$ & & 0.5 & \\
\hline 10 & $10 t 020$ & & 1 & deer & mipod dist condyle frg & & & $b$ & & 0.6 & \\
\hline 10 & 10 to 20 & & 1 & deet & tib shft frg & & & $b$ & & 1.2 & \\
\hline 10 & 10 to 20 & & 1 & deer & uha shfit frg & & & $\mathrm{b}$ & & 0.3 & \\
\hline 10 & $10 t 020$ & & 1 & deer & antler frg & & & $b$ & & 0.6 & \\
\hline 10 & $10+020$ & & 3 & turtle & shell fry & & & $b$ & & 0.3 & \\
\hline 10 & $10 \operatorname{to} 20$ & & 1 & turtle & shell frg & & & not & & 0.2 & \\
\hline 10 & $20 t 030$ & & 2 & deer & mtpod shft frg & & & $b$ & & 1.1 & \\
\hline 10 & $20 \operatorname{to} 30$ & & 1 & deer & uha shft frg & & & $b$ & & 0.5 & \\
\hline 10 & 20 to 30 & & 1 & deer & phx3 dist & $L$ & & $b$ & & 0.5 & \\
\hline 10 & $20 \operatorname{to} 30$ & & 3 & deer & tooth frg & & & not & & 1.7 & \\
\hline 10 & $20 t 030$ & & 1 & turkey & phx & & & $b$ & & 0.2 & \\
\hline 10 & $20 t 030$ & & 3 & turtle & shell frg & & & $b$ & & 0.5 & \\
\hline 10 & 20 to 30 & & 1 & turtle & shell frg & & & not & & 0.1 & \\
\hline 10 & 30 to 40 & & 1 & box & carapace frg & & & not & & 0.3 & \\
\hline 10 & $30 t 040$ & & 3 & box & peripheral frg & & & not & & 2 & \\
\hline 10 & $30 t 040$ & & 1 & deer & mand trow & $L$ & & not & & 14.7 & $\begin{array}{c}\text { inc } \mathrm{MI}+2 \\
\text { frg }\end{array}$ \\
\hline 10 & 30 to 40 & & 1 & deer & fem shft frg & $\mathrm{R}$ & & not & & 4 & \\
\hline 10 & 30 to 40 & & 1 & deer & hum dist med frg & $R$ & & not & & 10.3 & \\
\hline 10 & $30 t 040$ & & 4 & deer & mtpod shft frg & & & $b$ & & 2.5 & \\
\hline 10 & 30 to 40 & & 1 & deer & mtpod shft frg & & & not & & 3 & \\
\hline 10 & 30 to 40 & & 1 & deer & mittar prox lat frg & $L$ & & $b$ & & 1.5 & \\
\hline 10 & 30 to 40 & & 1 & deer & tib prox med frg & $\mathrm{R}$ & & $b$ & & 2.5 & in 2 frgs \\
\hline 10 & $30 t 040$ & & 3 & deer & antler frg & & & $b$ & & 1.6 & \\
\hline 10 & 30 to 40 & & 1 & deer & phxl dist & $R$ & & $b$ & & 1.1 & \\
\hline 10 & 30 to 40 & & 1 & deer & calc dist ant frg & $L$ & & $b$ & & 0.5 & \\
\hline 10 & $40 t 050$ & & 1 & box & peripheral frg & & & $b$ & & 1 & \\
\hline 10 & 40 to 50 & & 1 & deer & thoracic frg & A & & not & & 2.1 & \\
\hline 10 & $40 t 050$ & & 1 & deer & hum dist med frg & $\mathrm{R}$ & & $b$ & & 7.3 & \\
\hline 10 & 40 toso & & 1 & deer & antler frg & & & b & & 0.3 & \\
\hline 10 & 40 to 50 & & 1 & deer & phxl dist & & & $b$ & & 0.6 & \\
\hline 10 & 40 to50 & & 1 & deer & phx 2 prox & $L$ & & $b$ & & 0.7 & \\
\hline 10 & 40 to50 & & 2 & deer & tooth frg & & & not & & 0.4 & \\
\hline 10 & 40 to50 & & 1 & squirrel & scap head & $L$ & & not & & 0.1 & \\
\hline 10 & $40 t 050$ & & 2 & turtle & shell frg & & & b & & 0.4 & \\
\hline 11 & 28 & & 1 & deer & antler pedicle & & & not & grinder & 41.5 & plot 5 \\
\hline$\|$ & 38 & & 1 & deer & mtpod dist & & & $b$ & & 7.4 & plot 1 \\
\hline 11 & 38 & & 1 & deer & mtpod shft & & & $b$ & & 3.1 & plat 1 \\
\hline 11 & 0 tolo & & 1 & box & peripheral frg & & & $\mathrm{b}$ & & 0.6 & \\
\hline H & 10 to 20 & & 2 & deet & mipod shft hg & & & $b$ & & 0.7 & \\
\hline 11 & 10 to 20 & & 1 & deer & tib dist & $L$ & & $b$ & & 6.6 & \\
\hline
\end{tabular}


Table 28. (Continued)

\begin{tabular}{|c|c|c|c|c|c|c|c|c|c|c|c|}
\hline TU & Depth & Feat & Qty & Taxon & Elen Por & Side & Age & Bum & Mod & Wtg & Comments \\
\hline 11 & $10 t 020$ & & 1 & deer & antler frg & & & b & & 0.4 & \\
\hline 11 & $10 t 020$ & & 1 & deer & phx2 dist & $L$ & & $b$ & & 0.6 & \\
\hline 11 & 10 to 20 & & 2 & turtle & shell frg & & & $b$ & & 0.4 & \\
\hline 11 & $20+030$ & & 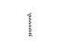 & box & hyo frg & $\mathrm{R}$ & & $b$ & & 0.4 & \\
\hline 11 & 20 to 30 & & 1 & box & peripheral frg & & & not & & 0.5 & \\
\hline 11 & 20 to 30 & & 1 & deer & mtrod shft frg & & & $b$ & scored & 1.8 & $\begin{array}{l}\text { bum } \\
\text { crack? }\end{array}$ \\
\hline 11 & $20 t 030$ & & 1 & deer & vert frg & & & not & & 9 & \\
\hline 11 & 20 to 30 & & 2 & deer & ascend ramus frg & $\mathrm{L}$ & & not & & 1.6 & \\
\hline 11 & 20 to 30 & & 1 & deer & petrous frg & & & $b$ & & 3 & \\
\hline 11 & $20 t 030$ & & 1 & deer & ntpod prox frg & & & $b$ & & 0.7 & \\
\hline 11 & $20 t 030$ & & 1 & deer & mtpod prox frg & & & $b$ & & 0.7 & \\
\hline$\Pi$ & $20 t 030$ & & 1 & deer & mtpod shft trg & & & $b$ & & 0.7 & \\
\hline 11 & 20 to 30 & & 1 & deer & ulna shft frg & & & $b$ & & 0.6 & \\
\hline 11 & $20 t 030$ & & 1 & deer & anter frg & & & $b$ & & 1.3 & \\
\hline 11 & $20 \mathrm{ro} 30$ & & 4 & deer & antler frg & & & not & & 12 & \\
\hline 11 & 201030 & & I & deer & phx3 & $L$ & & not & & 1.6 & \\
\hline II & $20 t 030$ & & 1 & deer & plx 3 dist & $L$ & & $b$ & & 0.3 & \\
\hline 11 & 20 to 30 & & 1 & deer & nay cub frg & $L$ & & $b$ & & 0.3 & \\
\hline 11 & 20 to 30 & & 1 & deer & M3 10 & $L$ & $3 y \mathrm{rs}$ & not & & 6 & \\
\hline 11 & 20 to 30 & & 1 & deer & tooth frg & & & not & & 0.2 & \\
\hline 11 & $20 t 030$ & & 1 & $\lg \operatorname{man}$ & 1,b.frag & & & not & $\begin{array}{l}\text { spatulate } \\
\text { frg }\end{array}$ & 0.5 & $\begin{array}{l}\text { ground, } \\
\text { polish }\end{array}$ \\
\hline 11 & 201030 & & 1 & opossum & mand trow & $\mathrm{R}$ & & not & & 2.7 & $\begin{array}{c}\text { inc } \\
M 1,2,3,4\end{array}$ \\
\hline 11 & 201030 & & 1 & raccoon & rad dist & $L$ & & $b$ & & 0.4 & \\
\hline 11 & 201030 & & 1 & turkey & phx frg & & & not & & 0.1 & \\
\hline 11 & $20 t 030$ & & 1 & turtle & l. befrag & & & not & & 0.1 & \\
\hline 11 & $30 t 040$ & & 1 & c'tail & M310 & $\mathrm{R}$ & & not & & 0.05 & \\
\hline 11 & 301040 & & 2 & deer & fen shtt frg & & & $b$ & mod frg & 2.9 & \\
\hline 11 & 301040 & & 1 & deer & mtpod shft fig & & & $b$ & mod frg & 0.9 & \\
\hline 11 & 301040 & & I & deer & diastema frg & $L$ & & $b$ & & 0.8 & \\
\hline 11 & $30 t 040$ & & I & deer & mpod dist condyle frg & & & 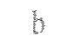 & & 1.2 & \\
\hline 11 & 301040 & & 1 & deer & mtpod prox frg & & & $b$ & & 1.4 & \\
\hline 11 & $30 t 040$ & & 3 & deer & mtpod shft frg & & & $b$ & & 2.7 & \\
\hline 11 & 301040 & & 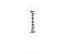 & deer & mitpod shft hrg & & & not & & 0.8 & \\
\hline 11 & 301040 & & 1 & deer & rad shft frg & & & $b$ & & 0.7 & \\
\hline 11 & 30040 & & I & deer & ulna shtt frg & & & $b$ & & 0.4 & \\
\hline 11 & 301040 & & 1 & deer & antler frg & & & $b$ & & 0.9 & \\
\hline 11 & 301040 & & 1 & deer & astrag frg & & & $b$ & & 1.8 & \\
\hline 11 & 306040 & & 1 & deer & dpm 310 & $L$ & $<6$ no & not & & 0.6 & neonatal? \\
\hline 11 & 301040 & & 1 & $\lg \mathrm{mam}$ & lb.frag & & & $b$ & mod frg & 1 & \\
\hline 11 & $30 \mathrm{to} 40$ & & 1 & rabbit & fem shft frg & & & $\mathrm{b}$ & & 0.4 & \\
\hline 11 & 300040 & & 1 & swamp & acetabulum & $\mathrm{L}$ & & not & & 1.5 & \\
\hline 11 & 300040 & & 2 & turtle & shell frg & & & not & & 0.6 & \\
\hline
\end{tabular}


Table 28. (Continued)

\begin{tabular}{|c|c|c|c|c|c|c|c|c|c|c|c|}
\hline TU & Depth & Feat & Qty & Taxon & Elem/Por & Side & Age & Burn & Mod & Wtg & Comments \\
\hline 11 & $40 t 050$ & & 1 & deer & mtpod shft frg & & & not & & 2.1 & \\
\hline 11 & $40 t 050$ & & 1 & deer & antler frg & & & $b$ & & 1.8 & \\
\hline 11 & 501088 & 3 & 1 & deer & mtpod prox frg & & & b & & 2.1 & \\
\hline 11 & $50 t 088$ & 3 & 1 & deer & mtpod shft frg & & & $b$ & & 1 & \\
\hline 11 & $50 t 088$ & 3 & 1 & deer & tooth frg & & & not & & 1.2 & \\
\hline 11 & 501088 & 3 & 1 & turkey & digit2 & $L$ & & not & & 0.3 & \\
\hline 11 & $50 \mathrm{to} 88$ & 3 & 3 & turtle & shell frg & & & not & & 1.9 & \\
\hline 12 & 0 tolo & & 1 & deer & mtpod shft frg & & & $b$ & & 0.3 & \\
\hline 12 & 0 tolo & & 2 & deer & antler frg & & & b & & 0.8 & \\
\hline 12 & 0 tolo & & 1 & deer & sesamoid & & & b & & 0.4 & \\
\hline 12 & Otolo & & 1 & lg mam & l.b.frag & & & b & blunt & 0.5 & \\
\hline 12 & Dtolo & & 1 & furkey & phx dist & & & $b$ & & 0.3 & \\
\hline 12 & Otolo & & 2 & turtle & shell frg & & & b & & 0.3 & \\
\hline 12 & 100 to! 107 & 5 & 1 & deer & thoracic facet & $\mathrm{A}$ & & b & & 1.6 & \\
\hline 12 & $100 t 0107$ & 5 & 2 & deer & antler frg & & & $b$ & & 1,1 & \\
\hline 12 & $100 t 0107$ & 5 & 1 & squirrel & ulna shft frg & $\mathrm{R}$ & & not & & 0.1 & \\
\hline 12 & $10 t 020$ & & 1 & box & peripheral frg & & & $b$ & & 0.5 & \\
\hline 12 & 10 to20 & & 1 & deer & Intpod shft frg & & & $b$ & chisel & 1 & frag only \\
\hline 12 & $10+020$ & & 1 & deer & mtpod prox frg & & & not & & 2.2 & \\
\hline 12 & $10 t 020$ & & 5 & deer & mtpod shft frg & & & $\mathrm{b}$ & & 2.8 & \\
\hline 12 & 101020 & & 1 & deer & rad shft frg & & & b & & 0.8 & \\
\hline 12 & 10 to 20 & & 6 & deer & antler frg & & & b & & 5 & \\
\hline 12 & 10 to20 & & 1 & deer & nav cub frg & L & & b & & 0.5 & \\
\hline 12 & 10020 & & 1 & $\lg$ mam & 1.b.frag & & & $b$ & blunt & 0.9 & \\
\hline 12 & 101020 & & 1 & squirrel & fem shft frg & L & & not & & 0.2 & \\
\hline 12 & 101020 & & 1 & swamp & premax & $\mathrm{R}$ & & not & & 0.2 & \\
\hline 12 & 101020 & & 1 & swamp & incisor up & $\mathrm{R}$ & & not & & 0.1 & broken \\
\hline 12 & 10 to20 & & 1 & turtle & shell frg & & & $b$ & & 0.2 & \\
\hline 12 & 201030 & & 1 & $b o x$ & scap frg & & & not & & 0.1 & \\
\hline 12 & 201030 & & 1 & box & hypo frg & $\mathrm{R}$ & & not & & 0.3 & \\
\hline 12 & $20 t 030$ & & 2 & box & peripheral frg & & & $b$ & & 1.2 & \\
\hline 12 & 201030 & & 1 & colubridae & vertebra & $\mathrm{A}$ & & not & & 0.1 & \\
\hline 12 & 200030 & & 1 & deer & cran post frg & L & & not & & 8.6 & $\begin{array}{c}\text { ine } \\
\text { petrous frg }\end{array}$ \\
\hline 12 & 201030 & & 1 & deer & mand condyle & $\mathrm{R}$ & & $b$ & & 1.1 & \\
\hline 12 & $20 t 030$ & & 1 & deer & mand condyle & $\mathrm{R}$ & & not & & 1.9 & \\
\hline 12 & 200030 & & 1 & deer & mtcar prox & $\mathrm{R}$ & & not & & 5.3 & \\
\hline 12 & $20 \operatorname{te} 30$ & & 1 & deer & motpod dist condyle frg & & & $b$ & & 0.4 & \\
\hline 12 & $20+030$ & & 4 & deer & mtpod shft frg & & & $b$ & & 3.8 & \\
\hline 12 & $20 t 030$ & & 1 & deer & mitar prox frg & & & b & & 1.3 & \\
\hline 12 & 201030 & & 8 & deer & antler frg & & & b & & 4.1 & \\
\hline 12 & 201030 & & 3 & deet & phx dist frg & & & b & & 1.3 & \\
\hline 12 & $20 t 030$ & & 1 & deet & phx prox frg & & & $b$ & & 0.4 & \\
\hline 12 & $20 t 030$ & & 1 & deer & phx2 dist & $\mathrm{R}$ & & not & & 1.3 & \\
\hline 12 & $20 t 030$ & & 1 & deer & tooth frg & & & not & & 0.1 & \\
\hline
\end{tabular}


Table 28. (Continued)

\begin{tabular}{|c|c|c|c|c|c|c|c|c|c|c|c|}
\hline TL & Deph & Feat & Qty & Taxon & Elempor & Side & Age & Bum & Mod & Wtg & Comments \\
\hline 12 & $20 t 030$ & & 1 & fish & vert & A & & not & & 0.1 & \\
\hline 12 & $20 t 030$ & & 1 & $\lg$ man & 1.b.frag & & & $b$ & tool shft & 1.5 & hipolish \\
\hline 12 & 20030 & & 1 & squirre: & parietal frg & $L$ & & not & & 0.1 & \\
\hline 12 & 200030 & & 1 & swamp & fem shet & & & $b$ & tool shft & 0.6 & hi polish \\
\hline 12 & 200030 & & 1 & swanp & $\mathrm{Mt3}$ & $\mathrm{R}$ & & not & & 0.5 & \\
\hline 12 & 20030 & & 1 & turkey & thoracic frg & $\mathrm{A}$ & & not & & 1 & \\
\hline 12 & $20 t 030$ & & 14 & turtle & shell frg & & & $b$ & & 3.6 & \\
\hline 12 & 301040 & & 1 & box & peripheral & & & $b$ & & 0.3 & \\
\hline 12 & 30040 & & 1 & box & plastron frg & & & $b$ & & 0.4 & \\
\hline 12 & $30 t 040$ & & 1 & ctall & frontal & $L$ & & not & & 0.5 & \\
\hline 12 & 301040 & & 1 & ctail & ulna shft & $\mathrm{R}$ & & not & & 0.3 & \\
\hline 12 & 301040 & & 1 & deer & thoracic facet & A & & $b$ & & 1.1 & \\
\hline 12 & $30 t 040$ & & 1 & deet & petrous & $\mathrm{R}$ & & $b$ & & 3.3 & in 2 frgs \\
\hline 12 & $30 t 040$ & & 1 & deer & mtpod dist condyle & & & $b$ & & 1.5 & \\
\hline 12 & $30 t 040$ & & 3 & deer & intpod shtt frg & & & $b$ & & 1.7 & \\
\hline 12 & $30+040$ & & 1 & deer & antler frg & & & not & & 2.1 & \\
\hline 12 & $30 t 040$ & & 1 & deer & phxl prox & $\mathrm{R}$ & & $\mathrm{b}$ & & 2.8 & \\
\hline 12 & $30 t 040$ & & 1 & nsh & vert & A & & not & & 0.1 & \\
\hline 12 & $30+040$ & & 1 & fish & unid & & & not & & 0.05 & \\
\hline 12 & $30 t 040$ & & 1 & kinostenndae & peripheral & & & not & & 0.1 & \\
\hline 12 & $30 t 040$ & & 1 & squirel & acetabulum & $L$ & & not & & 0.2 & \\
\hline 12 & 30040 & & 1 & scuirte & parietal & $L$ & & not & & 0.2 & \\
\hline 12 & $30 t 040$ & & 1 & squirrel & tib shft & L & & not & & 0.8 & \\
\hline 12 & $30 t 040$ & & 1 & turkey & tbet shft fry & & & not & & 0.5 & \\
\hline 12 & $30 t 040$ & & 2 & witle & shell frg & & & $\mathrm{b}$ & & 0.8 & \\
\hline 12 & 301040 & & 3 & turtle & shell frg & & & not & & 0.6 & \\
\hline 12 & $40 t 050$ & & 1 & boo & hyo frg & & & b & & 02 & \\
\hline 12 & $40 t 050$ & & 1 & ctail & tib shft frg & $\mathrm{R}$ & & not & & 0.2 & \\
\hline 12 & 40 to50 & & 1 & deer & vert facet & & & not & & 1.6 & \\
\hline 12 & 400050 & & 1 & deer & fem med dist frg & L & & $b$ & & 6.9 & \\
\hline 12 & $40 t 050$ & & 2 & deer & mtpod shft frg & & & b & & 2.8 & \\
\hline 12 & $40 \operatorname{tos} 60$ & & 1 & deer & ulna prox & $\mathrm{R}$ & & b & & 8.6 & \\
\hline 12 & $40 t 050$ & & 4 & deer & antler frg & & & b & & 3.5 & \\
\hline 12 & 40 to 50 & & 1 & deer & astragalus & $L$ & & b & & 7.8 & \\
\hline 12 & $40 t 050$ & & 1 & deer & podial frg & & & b & & 0.4 & \\
\hline 12 & $40 t 050$ & & 1 & deer & sesamoid & & & $\mathrm{b}$ & & 0.3 & \\
\hline 12 & $40 t 050$ & & 1 & deer & tooth frg & & & not & & 0.2 & \\
\hline 12 & 40050 & & 1 & opossum & frontal frg & $A$ & & not & & 0.8 & \\
\hline 12 & 40050 & & 1 & squirrel & clavicle & 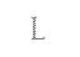 & & not & & 0.1 & \\
\hline 12 & 400050 & & 1 & squimel & hum shft & $\mathrm{R}$ & & not & & 0.2 & \\
\hline 12 & 401050 & & 1 & sq̣ume & the shet & $\mathrm{R}$ & & not & & 0.6 & \\
\hline 12 & 40050 & & 1 & toadfrug & long bone & & & not & & 0.1 & \\
\hline 12 & $40 t 050$ & & 1 & turley & tmt shft frg & & & not & & 1 & \\
\hline 12 & $40 t 050$ & & 1 & turkey & una dist & $\mathrm{R}$ & & $b$ & & 2.3 & \\
\hline 12 & 40050 & & 6 & wrile & shell irg & & & b & & 1.3 & \\
\hline
\end{tabular}


Table 28. (Continued)

\begin{tabular}{|c|c|c|c|c|c|c|c|c|c|c|c|}
\hline TU & Deph & Feat & Qty & Taxon & Elem Por & Side & Age & Burn & Mod & Wt/g & Comments \\
\hline 12 & 500060 & 5 & 1 & box & hypo frg & R & & b & & 0.9 & FS \\
\hline 12 & 501060 & 5 & 1 & ctail & vertebra & A & $\mathrm{imm}$ & $b$ & & 0.2 & FS \\
\hline 12 & $50 t 060$ & 5 & 1 & $c^{\prime}$ tail & frontal & L & & not & & 0.4 & \\
\hline 12 & $50 t 060$ & 5 & 1 & $c^{\prime}$ tail & tib dist & $\mathrm{R}$ & & b & & 0.1 & FS \\
\hline 12 & $50 \operatorname{to6} 0$ & 5 & 1 & deer & ascend ram frg & R & & not & & 2.2 & FS \\
\hline 12 & $50 t 060$ & 5 & 1 & deer & fem head & $\mathrm{L}$ & & not & & 11.6 & \\
\hline 12 & $50 t 060$ & 5 & 1 & deer & fem shft fry & & & $b$ & & 5.7 & FS \\
\hline 12 & $50 t 060$ & 5 & 1 & deer & mtpod shtt frg & & & b & & 0.6 & \\
\hline 12 & $50 t 060$ & 5 & 1 & deer & mtpod shft frg & & & b & & 1.9 & FS \\
\hline 12 & 50 to60 & 5 & 1 & deer & mttar prox frg & & & b & & 2.6 & \\
\hline 12 & 50 to60 & 5 & 1 & deer & ulnar notch frg & R & & b & & 1.7 & FS \\
\hline 12 & $50+060$ & 5 & 2 & deer & antler frg & & & b & & 2 & FS \\
\hline 12 & 50 to60 & 5 & 1 & deer & phx dist frg & & & b & & 0.6 & \\
\hline 12 & 50 to60 & 5 & 1 & deer & phx 1 dist & $\mathrm{R}$ & & b & & 2.3 & \\
\hline 12 & $50 t 060$ & 5 & 1 & deer & sesamoid & & & $b$ & & 0.1 & FS \\
\hline 12 & $50 t 060$ & 5 & 1 & rabbit & incisor to frg & & & not & & 0.2 & FS \\
\hline 12 & 50 to60 & 5 & 1 & squirrel & clavicle & L & & not & & 0.1 & FS \\
\hline 12 & 50 to60 & 5 & 1 & swamp & hum dist & $\mathrm{R}$ & & not & & 0.3 & \\
\hline 12 & 50 to60 & 5 & 1 & swamp & tib dist & L & & not & & 0.5 & \\
\hline 12 & $50 t 060$ & 5 & 1 & turtle & shell frg & & & $b$ & & 0.3 & \\
\hline 12 & 50 to60 & 5 & 5 & turtle & shell frg & & & b & & 1.3 & FS \\
\hline 12 & 60 to70 & 5 & 1 & box & peripheral & & & $b$ & & 2.6 & \\
\hline 12 & $60 t 070$ & 5 & 1 & box & plastron frg & & & $\mathrm{b}$ & & 0.6 & broken \\
\hline 12 & 601070 & 5 & 1 & $c^{\prime}$ tail & rad dist & L & & not & & 0.3 & \\
\hline 12 & $60 t 070$ & 5 & 1 & c'tail & thb shft frg & & & b & & 1.2 & \\
\hline 12 & 601070 & 5 & 1 & colubridae & vertebra & A & & not & & 0.2 & med-size \\
\hline 12 & 601070 & 5 & 1 & deer & $a c e t a b$ frg & L & & $\mathrm{b}$ & & 5.7 & \\
\hline 12 & 60 to 70 & 5 & 2 & deer & mtpod shft frg & & & b & & 0.8 & \\
\hline 12 & $60 \mathrm{to} 70$ & 5 & 1 & deer & mitar prox frg & & & b & & 2.7 & \\
\hline 12 & 601070 & 5 & 4 & deer & antler frg & & & b & & 7.6 & \\
\hline 12 & 601070 & 5 & 1 & deer & phx2 dist & L & & b & & 0.3 & \\
\hline 12 & 60 to 70 & 5 & 1 & deer & phx 2 prox & L & & $b$ & & 0.9 & \\
\hline 12 & 60 to 70 & 5 & 1 & deer & paradigit frg & & & not & & 0.2 & \\
\hline 12 & 601070 & 5 & $i$ & deer & nav cub post med frg & L & & b & & 3.2 & \\
\hline 12 & $60 t 070$ & 5 & 1 & deer & podial frg & & & $\mathrm{b}$ & & 0.4 & cf magnum \\
\hline 12 & $60 \mathrm{to} 70$ & 5 & 1 & thad/frog & long bone & & & not & & 0.1 & med-size \\
\hline 12 & 601070 & 5 & 2 & turtle & shell frg & & & $b$ & & 0.6 & \\
\hline 12 & 651075 & 5 & 1 & ctail & $\max$ frg & L & & not & & 0.2 & FS \\
\hline 12 & $65 t 075$ & 5 & 1 & $c^{\prime}$ tail & astragalus & L & & not & & 0.2 & FS \\
\hline 12 & 651075 & 5 & 1 & $c^{\prime}$ tail & tooth upper & & & not & & 0.2 & FS \\
\hline 12 & 650075 & 5 & 0 & deer & M1 lo & $R$ & $>5$ & not & & 0 & FS \\
\hline 12 & 651075 & 5 & 0 & deer & M2 10 & $\mathrm{R}$ & $>5$ & not & & 0 & FS \\
\hline 12 & 65 to 75 & 5 & 1 & deer & mand trow & $\mathrm{R}$ & $>5$ & not & & 8.3 & FS \\
\hline 12 & 651075 & 5 & 1 & deer & nasal frg & $\mathrm{R}$ & & not & & 1.8 & FS \\
\hline 12 & 651075 & 5 & 1 & deer & mtpod shft frg & & & $b$ & & 0.7 & FS \\
\hline
\end{tabular}


Table 28. (Conimued)

\begin{tabular}{|c|c|c|c|c|c|c|c|c|c|c|c|}
\hline TU & Depth & Feat & Qty & Taxon & Elem Por & Side & Age & Burn & Mod & Why & Comments \\
\hline 12 & 651075 & 5 & 1 & deer & pisiform & $L$ & & not & & 0.9 & FS \\
\hline 12 & 651075 & 5 & 1 & squirrel & premax & $L$ & & not & & 0.3 & $\begin{array}{c}\text { FS; } \\
\text { In } 2 \text { frgs }\end{array}$ \\
\hline 12 & $65 t 075$ & 5 & 1 & squirrel & fbula & & & not & & 0.1 & FS \\
\hline 12 & $65 t 075$ & 5 & 1 & squirrel & mtpod prox & & & $\mathrm{b}$ & & 0.05 & FS \\
\hline 12 & 65075 & 5 & 1 & squirrel & mtpodial & & & not & & 0.1 & FS \\
\hline 12 & $65 t 075$ & 5 & 2 & squirrel & incisor upper & & & not & & 0.3 & FS \\
\hline 12 & $65 t 075$ & 5 & 1 & swamp & tib dist & $L$ & & not & & 0.4 & FS \\
\hline 12 & 651075 & $3^{3}$ & 1 & swamp & unar notch & $\mathrm{R}$ & & $b$ & & 0.3 & $\mathrm{FS}$ \\
\hline 12 & $65 t 075$ & 5 & 1 & turkey & digit & & & not & & 0.3 & FS \\
\hline 12 & $65 t 075$ & 5 & 1 & turlle & shell frg & & & $\mathrm{b}$ & & 0.1 & FS \\
\hline 12 & $70 t 080$ & 5 & 1 & ctail & scap neck & $L$ & & b & & 0.1 & \\
\hline 12 & 701080 & 5 & 1 & deer & ilum frg & $\mathrm{R}$ & & $b$ & & 4 & sm indiy \\
\hline 12 & $70 t 080$ & 5 & 1 & deer & vert centrum & $A$ & $\mathrm{imm}$ & b & & 1.8 & \\
\hline 12 & 701080 & 5 & 1 & deer & vert facet & & & $b$ & & 0.4 & \\
\hline 12 & 706080 & 5 & 1 & deer & mand condyle & $\mathrm{R}$ & & not & & 3.3 & \\
\hline 12 & 701080 & 5 & 1 & deer & mtpod dist condyle & & & $b$ & & 1.9 & \\
\hline 12 & 701080 & 5 & 2 & deer & mipod shft frg & & & $b$ & & 0.7 & \\
\hline 12 & $70 t 080$ & 5 & 1 & deer & mtpod shft frg & & & not & & 2 & \\
\hline 12 & $70 t 080$ & 5 & 1 & deer & rad shft frg & & & $\mathrm{b}$ & & 0.5 & \\
\hline 12 & 706080 & 5 & 1 & deer & tib shft frg & & & b & & 1 & \\
\hline 12 & $70 t 080$ & 5 & 8 & deer & anter frg & & & $b$ & & 10 & \\
\hline 12 & $70 t 080$ & 5 & 1 & deer & phx dist frg & & & b & & 0.4 & \\
\hline 12 & 706080 & $\xi$ & 1 & deer & phxl dist & L & & b & & 1.7 & \\
\hline 12 & $30 t 080$ & 5 & 1 & deer & cale platform & $\mathrm{R}$ & & $b$ & & 4.5 & \\
\hline 12 & $70 t 080$ & 5 & 1 & drum & otolith & $\mathrm{R}$ & & $b$ & & 0.7 & $\begin{array}{c}\mathrm{L}=15 ; \\
\mathrm{W}=11 \mathrm{~mm}\end{array}$ \\
\hline 12 & 701080 & 5 & 1 & opossum & stap head & $\mathrm{R}$ & & not & & 1.4 & \\
\hline 12 & 70 to80 & 5 & 1 & squirrel & nasal & $\mathrm{R}$ & & not & & 0.1 & \\
\hline 12 & 700080 & 5 & 1 & swamp & rad dist & $L$ & & not & & 0.5 & \\
\hline 12 & 700080 & 5 & 1 & swamp & uina dist & $L$ & & not & & 0.2 & \\
\hline 12 & $70 t 080$ & $\xi$ & 2 & turte & shell frag & & & $b$ & & 1 & \\
\hline 12 & 75085 & 5 & 1 & deer & mitur shft frg & & & $b$ & $\begin{array}{l}\text { lool } \\
\text { shaft }\end{array}$ & 3.5 & FS \\
\hline 12 & $75 t 085$ & 5 & 2 & deer & antler frg & & & $b$ & & 1.1 & FS \\
\hline 12 & $75 t 085$ & 5 & 1 & deer & phx dist fry & & & b & & 0.1 & FS \\
\hline 12 & $75 t 085$ & 5 & 1 & lgmam & unid & & & b sh & namp awl tip & 1.9 & FS \\
\hline 12 & 751085 & 5 & 1 & squirrel & mtpodial & & & not & & 0.1 & FS \\
\hline 12 & $75 t 085$ & 5 & 1 & squirrel & whar notch & $\mathrm{R}$ & & $\mathrm{b}$ & & 0.1 & FS \\
\hline 12 & 751085 & 5 & 1 & turkey & tmo dist frg & & & b & & 0.1 & FS \\
\hline 12 & 75085 & 5 & 1 & turkey & me shft frg & & & $b$ & & 1.3 & $\mathrm{FS}$ \\
\hline 12 & $80 t 090$ & 5 & 1 & deer & nasal & $\mathrm{R}$ & & not & & 1.7 & \\
\hline 12 & 808090 & 5 & 3 & deer & minod shft frg & & & b & & 5.7 & \\
\hline 12 & $80 t 090$ & 5 & 1 & deer & rad shft frg & & & $b$ & & 2.2 & \\
\hline
\end{tabular}


Table 28. (Conimued)

\begin{tabular}{|c|c|c|c|c|c|c|c|c|c|c|c|}
\hline ח! & Depth & Feat & Qty & Taxon & ElenPor & Side & Age & Bum & Mod & Wrg & Comments \\
\hline 12 & $80 t 000$ & 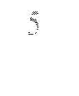 & 1 & deer & the dist ned the & $L$ & & $b$ & & 0.5 & $\begin{array}{c}\text { process } \\
\text { only }\end{array}$ \\
\hline 12 & 80000 & 5 & 1 & deer & tib $d x$ & $\mathrm{R}$ & imm & not & & 10,9 & $\begin{array}{l}2 \text { frgs } \\
\text { xmend }\end{array}$ \\
\hline 12 & $80 t 090$ & 5 & 3 & deer & anter fry & & & $b$ & & 7.9 & \\
\hline 12 & 801090 & 5 & 1 & swamp & mand frg & $\mathrm{R}$ & & not & & 0.7 & $\begin{array}{l}2 \text { frys } \\
\text { xmend }\end{array}$ \\
\hline 12 & 80 to 90 & 5 & 1 & swamp & hum dist & $\mathrm{R}$ & & not & & 0.7 & \\
\hline 12 & 801000 & $\xi$ & 1 & turle & shell fig & & & $b$ & & 0.1 & \\
\hline 12 & $80 t 000$ & 5 & 1 & turte & shell trg & & & not & & 0.5 & \\
\hline 12 & 90 tolo0 & 5 & 2 & deer & antler frg & & & $b$ & & 2.8 & \\
\hline 12 & $90 t 0100$ & 5 & 1 & deer & phu dist frg & & & $b$ & & 0.2 & \\
\hline 13 & 101020 & & 1 & deer & petrous frg & & & $b$ & & 1.8 & \\
\hline 13 & $10 t 020$ & & 3 & deer & mtpod shtt irg & & & $b$ & & 1.6 & \\
\hline 13 & $10 t 020$ & & 2 & mntle & shell frg & & & $b$ & & 0,3 & \\
\hline 13 & $20+030$ & & 1 & dedr & rbhead trg & & & $b$ & & 0.3 & \\
\hline 13 & 206030 & & 3 & deer & mtpod sht frg & & & $b$ & & 1.5 & \\
\hline 13 & $20+030$ & & 1 & deer & mtpod sht frg & & & not & & 0.5 & \\
\hline 13 & 201030 & & 1 & turle & hell me & & & $b$ & & 0.4 & \\
\hline 13 & $30+040$ & & 1 & doer & palatine fre & A & & $b$ & & 1 & rs \\
\hline 13 & 301040 & & 1 & deer & em sht trg & & & not & & 3.8 & \\
\hline 13 & $30 t 040$ & & 1 & deer & mtpod dist condyle & & & not & & 2.7 & \\
\hline 13 & $30 t 040$ & & 1 & deer & mipod prox mag & & & not & & 3.9 & \\
\hline 13 & 301040 & & 1 & deer & antler frg & & & $b$ & & 1 & FS \\
\hline 13 & 301040 & & 1 & squirel & fen shttrg & L. & & not & & 0.4 & \\
\hline 13 & 301040 & & 0 & swamp & M110 & L. & & not & & 0 & FS \\
\hline 13 & $30 t 040$ & & 0 & swamp & Melo & $L$ & & not & & 0 & FS \\
\hline 13 & $30 t 040$ & & 0 & swamp & PM4lo & $L$ & & not & & 0 & FS \\
\hline 13 & 306040 & & ! & swamp & mand trow & L & & not & & 0.9 & FS \\
\hline 13 & $30+040$ & & 2 & turtle & shell frg & & & $b$ & & 0.2 & $\mathrm{Fs}$ \\
\hline $11+4$ & 551075 & 6 & 1 & deer & petrous & $L$ & & not & & 43 & $\operatorname{stan} A$ \\
\hline $11+4$ & 551075 & 6 & 1 & deer & Wum dist frg & & & not & & 3 & $\operatorname{stain} A$ \\
\hline $9 \mathrm{~A}$ & 30040 & & 1 & deer & nitpod shlt frg & & & $b$ & & 0.4 & \\
\hline $9 \mathrm{~A}$ & 301040 & & 1 & deer & anler in & & & $b$ & & 05 & \\
\hline $9 \mathrm{~A}$ & 306040 & & 1 & deer & cale shat & $\mathrm{R}$ & & not & & 4.4 & \\
\hline $9 \mathrm{~A}$ & 301040 & & 1 & deer & secamoid & & & not & & 0.6 & \\
\hline $9 A$ & $30 t 040$ & & 1 & fish & vert frg & $A$ & & not & & 0.2 & \\
\hline B2 & $\operatorname{surf}$ & & 1 & dear & hum dist ing & & & b & & 1.5 & \\
\hline B21 & surf & & 1 & urte & shell trg & & & $b$ & & 01 & \\
\hline B22 & surf & & 1 & deer & mowed shtithy & & & $b$ & & 07 & \\
\hline B22 & $\operatorname{sinf}$ & & 1 & swamp & rad dist & L & & b & & 0.1 & \\
\hline B 23 & surf & & 1 & deer & anter fry & & & $b$ & & 0.4 & \\
\hline B 37 & surf & & 1 & wurle & shell fry & & & b & & 0.1 & \\
\hline B37 & surf & & 3 & turte & shell frg & & & $b$ & & 0.1 & \\
\hline $\mathrm{B} 42$ & surf & & 1 & wrte & shell fry & & & $b$ & & 01 & \\
\hline
\end{tabular}


Table 28. (Continued)

\begin{tabular}{|c|c|c|c|c|c|c|c|c|c|c|c|}
\hline TL! & Depth & Feat & Qty & Taxon & Eempor & Side & Age & Burn & Mod & Wtg & Comments \\
\hline none & 300044 & 2 & 1 & ctail & innom lry & & & $b$ & & 0.2 & \\
\hline none & 30 to 44 & 2 & 1 & ctail & prenax & $L$ & & not & & 0.2 & \\
\hline none & 30 to44 & 2 & 1 & ctail & nariwuar & $L$ & & $b$ & & 0.1 & \\
\hline none & 301044 & 2 & 1 & ctail & incisor lower & $\mathrm{R}$ & & not & & 0.1 & \\
\hline none & $30 t 044$ & 2 & 1 & ctal & incisor up & $L$ & & not & & 0.1 & \\
\hline none & 30 to44 & 2 & 1 & c'tail & M3up & & & not & & 0.05 & \\
\hline none & 306044 & 2 & 2 & deer & mtpod shft fry & & & $b$ & & 0.8 & \\
\hline none & 301044 & 2 & 1 & deer & mtpod shft fry & & & not & & 3 & \\
\hline none & 30044 & 2 & 1 & deer & antler frg & & & $b$ & & 04 & \\
\hline none & 306044 & 2 & 1 & deer & PM3 lo frg & $L$ & & not & & 0.5 & \\
\hline none & 301044 & 2 & 1 & fish & vert & A & & not & & 0.05 & \\
\hline none & $30 t 044$ & 2 & 1 & fish & dentary & & & not & & 0.2 & \\
\hline none & 30 to 44 & 2 & 1 & fish & spinous process & & & not & & 0.05 & \\
\hline none & $30 t 044$ & 2 & 1 & squirrel & nasal & $\mathrm{R}$ & & not & & 0.1 & \\
\hline none & 301044 & 2 & 1 & squirrel & squamosal & $\mathrm{R}$ & & not & & 0.1 & \\
\hline none & 301044 & 2 & 1 & squirrel & mtpodial & & & not & & 0.1 & \\
\hline none & 30044 & 2 & 1 & squirrel & tib dist & L & & not & & 0.1 & \\
\hline none & $30 t 044$ & 2 & 5 & turtle & shell frg & & & $b$ & & 0.6 & \\
\hline none & $30 t 044$ & 2 & 1 & turtle & shell frg & & & not & & 0.1 & \\
\hline none & gen surf & & 1 & deer & mtpod shft firg & & & $b$ & & 0.4 & \\
\hline none & gen surf & & 1 & deer & nav cub fry & $\mathrm{R}$ & & not & & 3.6 & \\
\hline ST5 & $0 t 020$ & & 1 & deer & tooth root & & & $b$ & & 0.3 & \\
\hline ST5 & 200040 & & 1 & deer & fem head & L & & $\mathrm{b}$ & & 6.7 & 2 frgs \\
\hline ST5 & $20 t 040$ & & I & deer & calc shft & $\mathrm{R}$ & & not & & 2.1 & \\
\hline ST6 & 201040 & & 2 & deer & antler frg & & & $b$ & & 0.9 & \\
\hline ST6 & 20 to 40 & & 1 & deer & astrag dist & $\mathrm{R}$ & & $b$ & & 5.5 & \\
\hline
\end{tabular}

\section{ASSEMBLAGE COMPOSITION}

\section{Class Osteichthyes}

\section{Onder Perciformes, Family Sciaenidae}

Freshwater drum (Aplodinotus grumniens) is represented by one burned otolith, recovered from a large pit feature (Feature 5) in Unit 12,70 to $80 \mathrm{~cm}$ bs. Based on specimen measurements, this individual's body length is $377 \mathrm{~mm}$, and body weight is 740 grams (Witt 1960). At just over 26 pounds, this was quite a large fish. The preferred habitat of the freshwater drum includes lake shallows and large rivers, and it produces a grunting sound that is audible to man (Collins 1959).

Additionally, seven unidentifiable fish bone fragments were recovered from two levels (20 to 30 and 30 to $40 \mathrm{~cm}$ bs) in Unit 12. Unit 9 ( 30 to $40 \mathrm{~cm}$ bs). and one of the pit features (Feature 2, 30 to $44 \mathrm{~cm}$ bs). None of these elements are burned. Fragmentation prevented specific identification. 
The presence of fish remains in the collection is not unusual. The project area includes aquatic habitats, and fish undoubtedly occupied the fluctuating local creeks and rivers. The Leaning Rock site is located on a small intermittent stream in the headwater region of Prairie Creek and some $15 \mathrm{~km}$ from the Sabine River, the nearest large water source that could have produced the large drum fish. Fish were used extensively by the Caddo Indians, with no known limitations on variety or size (Newcomb 1993). They were caught in several ways, employing trotlines: short lines hung about a foot apart from a long line with hooks baited with "dough bait" or meat. The line can be checked several times a day, yielding good-sized fish. The method is almost identical to the one used today.

\section{Class Amphibia}

\section{Order Anura, Family Indeterminate}

Toad/frog is represented by two long bones, recovered from two levels in Unit 12. There are several species of toads and frogs that inhabit the area, but lack of comparative material prevented specific identification. Because of their moist skin, most frogs and toads are prone to desiccation, and therefore confined to wet or moist habitats. However, some species have adapted to more arid habitats by burrowing into the soil or hiding beneath rocks or logs to avoid the heat (Behler 1995). Because toads secrete a substance that causes skin irritation, they are probably not a popular dietary supplement except during times of stress. However, frog legs are a delicacy still enjoyed today. These may represent a food gathered by children as they could have been easily procured and would have been quite plentiful during warmer weather.

\section{Class Reptilia}

\section{Order Testudinata, Family Kinostenidae}

Musk/mud turtle is represented by four shell fragments. They were recovered from four levels in three units, and two fragments are burned. There are two genera north of Mexico: Stemotherus, with four species of musk turtles, and Kinosternon, with five species of mud turtles. Currently, the mud turtle ( $K$. subrubrum), the musk turtle (S. carinatus), and the stinkpot (S, odorans) occupy the area.

These turtles all generally prefer slow-moving or shallow waters with soft bottoms and abundant vegetation. They all have two pairs of musk glands beneath the border of the carapace, and the secretions are very offensive (Behler 1995).

\section{Order Testudinata, Family Emydidae}

Forty-five pieces of turtle shell and two post-cranial elements from box turtle (Terrapene sp.) were recovered from the Leaning Rock site, representing at least two individuals. Thirty-one fragments are burned. Box turtles, which are strictly North American, range widely over the eastern and central United States and into the Southwest, and they also occur in many parts of Mexico. These are dry-land turtles that close their shells tightly when danger threatens (Conant 1975).

Unidentifiable turtle is represented by 152 shell fragments, one long bone fragment, and one toe bone. They were recovered from surface collection and numerous levels in all 13 units, including Features 2,3 , and 5 . Most of these specimens are burned (n=134). Based on the size of the shell fragments, they are probably the remains of the box turtle or musk/mud turtle. Both are common turtles in the area, and would have been easily procured by the population as an additional dietary supplement. It is noted in Table 28 that the toe bone is from 
a large individual, possibly a pond turtle such as Chrwemys sp., snapper (Chelydridae), or softshell (Trionix sp.). However, none of these larger lurtles were identified in the collection.

\section{Order Squamata, Suborder Serpentes, Family Colubridae}

Three vertebrae from non-poisonous snake were recovered from Level 3 in Units 1 and 12, and Level 7 in Unit 12, Feature 5 . The specimens are not bumed, and may or may not be subsistence debris.

\section{Class Aves}

\section{Order Galliformes, Family Phasianidae}

Turkey (Meleagris gallopavo) is represented by 17 specimens. Seven fragments are burned, and a minimum of one individual was present at the site. The bones were recovered from several levels in eight units, including Features 3 and 5 . The two pieces of eggshell from Level 7 in Unit I may also represent turkey. The turkey occurs as wild fowl in open woodland environments (Robbins 1983). Although they are good fliers, turkeys prefer to run from predators, and roost in trees (Collins 1959).

\section{Class Mammalia}

\section{Order Marsupialia, Family Didelphidae}

Four elements from Virginia opossum (Didelphis virginiana) were recovered from four levels in three units, and the specimens are not burned. The opossum is widespread throughout eastern Texas, and probably occur in every county; next to the raccoon, opossums are probably the most common medium-sized mammal in eastern Texas (Schmidly 1983).

Opossums are primarily inhabitants of deciduous woodlands, but are often found in prairies, marshes, and farmlands. Hollow trees are preferred sites, but they will den in woodpiles, rock piles, and other areas such as underground burrows previously dug or built by other animals since they are not good diggers (Davis 1978).

The opossum is the only marsupial in North America, and is among the most primitive of living mammals. It can be found in woodlands and along streams throughout most of the eastern half of the country, south into Mexico, and along the Pacific coast. Sometimes it is hunted for sport, especially in the South, but the edible meat is oily. Occasionally it is blamed for poultry raids, but also consumes mice and insects. The fur is salable, but of little value (Burt and Grossenheider 1980).

\section{Onler Lagomorpha, Family Leporidae}

Two species of cottontail rabbit (Sylvilagus sp.) inhabit the area: the Eastern cottontail (S. floridanus) prefers heavy brush, strips of forest with open areas, edges of swamps, and weed patches; swamp rabbit (S. aquuticus) prefers swamps, marshes, and wet bottomlands (Burt and Grossenheider 1980). Osteologically, the swamp rabbit is the largest of the cottontails within its range (Davis 1978). Eastem cottontail is represented by 24 elements. recovered from seven units, including Features 2 and 5. Eight pieces are burned. Swamp rabbit is represented by 19 specimens, and only three pleces are burned. They were found in six units, including Feature 5 . Both rabbits each have an MNI of two. Rabbits are easily procured by hunters and frequently found in Caddo faunal assemblages. 
The Eastern cottontail occurs throughout eastern Texas in all vegetational regions and in all habitats except the aquatic ones. In the forested Pineywoods region. the swamp rabbit is usually more common than any other lagomorph in second-growth timber over 12 years old (Schmidly 1983).

\section{Order Rodentia, Family Scuridae}

Squirrel (Sciurus sp.) is represented by 30 bone fragments, recovered from six units (including Features 2 and 5). Only two specimens are burned. A minimum of two individuals are present in the site assemblage. Three species of squirrel occupy the area. The fox squirrel ( $S$. niger) prefers pine forests with interspersed clearings, and the gray squirrel (S. comlinensis) prefers hardwood forests with nut trees and river bottoms (Burt and Grossenheider 1980). It is unlikely that the specimens recovered are the remains of the third species, the southern flying squirrel (Glaucomys volans) because it is a much smaller squirrel and the elements recovered at the site are from a larger animal. Gray squirrels are seldom found in the pine woods and upland forests. Fox squirrels occur wherever adequate timbered habitats exist in eastern Texas, although they seemingly occur in greater densities in the mature oak-hickory woodlands of the central portion of the region (Schmidly 1983).

\section{Order Rodentia, Family Geomyidae}

Pocket gopher (Geomys sp.) is represented by two burned toe bones, recovered from fine screen samples taken in two levels of Unit 1 . These are probably the remains of Louisiana pocket gopher ( $G$. breviceps), but a specific identification was not attempted based only on these toe bones.

Pocket gophers in eastern Texas have historically been grouped in one wide-ranging, morphologically variable species, Geomys bursarius. However, recent studies have revealed that in actuality there are three species in eastern Texas. The Louisiana pocket gopher has a continuous distribution east of the Brazos River in all vegetation regions where soils are suitable. Soils having a low content of clay and a high content of sand are preferred by these gophers (Schmidly 1983).

\section{Order Carnivora, Family Procyonidae}

Raccoon (Procyon lotor) is represented by one burned radius fragment, found in Level 3 of Unit 11 . They seldom occur far from water, and do much of their foraging near or in bodies of water (Davis 1978).

Raccoons are among the most common fur-bearing mammals in eastern Texas, and they occur in all vegetational regions. They prefer hardwood-timbered habitats and are especially abundant along the larger streams, where wide floodplains and adjacent sloping uplands support mature stands of oak timber together with other hardwoods. They also occur in a variety of other habitats, including bottomland swamps, marshes, around lakes or ponds surrounded by narrow stands of trees, famlands (especially those with cornfields), and heavily wooded residential areas in cities (Schmidly 1983).

\section{Order Artiodactyla, Family Cervidae}

Deer (Odocolleus sp.) is represented by 380 bone fragments, with a site MNI of three. They range in age from immature (less than six months old) to approximately five years old. This estimate is based on tooth wear and eruption. Every unit and practically every level yielded deer remains, including Features $2,3,5$, and 6 . Whitetail Deer $(O$. virginianus) is the only species that occupies the general area. found in forests, swamps, and open brushy areas (Burt and Grossenheider 1980). They occur in all vegetal regions, but in eastem Texas they are found 
in larger numbers in timbered areas (Schmidly 1983). Deer is the most common large game animal preferred by the Caddo, and also one of their main subsistence animals. The Caddos were adept imitators of deer, and a hunter disguised with the antlers and hide of a deer was able to approach his quarry closely, and even to attract it to himself (Newcomb 1993).

It is generally thought that non-meat parts of large game are frequently left at the hunt/kill location and only those body parts with high meat yield or tool value are transported from the hunting area back to the habitation site as distance increases. The recovery of certain elements, or lack of recovery, can be considered evidence of the procurement strategles practiced. In general, the list of deer elements (Table 29) is dominated by long bones. Extreme lower limb bones, cranial, and axial elements were also recovered, but quantities are relatively low. Pieces of antler and tooth fragments comprise the remainder of the list of elements recovered but breakage must be considered. The majority of deer remains consists of long bone fragments, supporting the theory that mainly useful and/or important portions are transported. These limb bones also provided material necessary for tool manufacturing.

\section{HABITAT, SEASONALITY, AND HUNTING PRACTICES}

Aquatic species are abundant, but their contribution to the diet is probably minimal, based on the small size of most of the animals recovered. Wooded edges were hunted for deer, cottontail, and turkey. The remaining animals were found in woodlands and bottomlands. A summary of habitats preferred is listed in Table 30.

The Leaning Rock faunal assemblage suggests that the site was probably occupied throughout the year because the animals identified would have been available during all seasons, specifically the fish, turkey, rabbits, and squirrel. However, the young deer indicates hunting during the summer or early fall, as offspring are born in the spring. The shed antler pedicle from Unit 11 implies a late winter kill. Winter hunting may also be indicated by the presence of the opossum and raccoon. Their pelts become especially luxurious and more valued than the rest of the year. Turtles, however, were probably obtained during warmer times of the year.

The recovery of small animals, especially the turtles, suggests the possibility that entire families took part in the procurement of food. These animals could have been obtained by women and children using passive hunting techniques. Men were generally the hunters of deer, which surely provided the main meat source for the Caddo. However, turtle, opossum, rabbit, squirrel, pocket gopher, and raccoon are also important dietary resources.

\section{MODIFIED BONE}

Modified bone refers to faunal specimens with evidence of human alteration such as cutting, grinding, or other modifications, as well as finished bone tools or jewelry. The Leaning Rock site yielded 19 modified specimens (Table 31), and the majority came from Units 11 and 12 . However, since most of them are broken, few inferences can be deduced about the associated activities of the site occupants, such as stone tool production, plant food processing, or hide processing. For purposes specific to this site, they have been grouped into nine categories, distinguished by assumed function and/or form. The system is based loosely on Kidder's (1932) scheme for bone artifacts from Pecos, New Mexico, and an adaptation of this scheme by Beach and Causey (1984) for Arroyo Hondo, New Mexico. In large modified bone assemblages, the categories are often primarily sorted by anatomical element, animal used, then function. The following section describes each of the artifacts and recovery provenience. 
Table 29. Composition of Faunal Elements from 41 SM325.

\begin{tabular}{|c|c|c|c|c|c|c|c|c|c|}
\hline Scientific Name & Common Name & $\begin{array}{c}\text { Element } \\
\text { unid. }\end{array}$ & cranial & teeth & axial & $\begin{array}{l}\text { long } \\
\text { bone }\end{array}$ & podial & phalanx & other \\
\hline Osteichthyes & unid. bony fish & 1 & 1 & & 4 & & & & 1 \\
\hline Aplodinotus grunniens & freshwater drum & & 1 & & & & & & \\
\hline Anura & toad/frog & & & & & 2 & & & \\
\hline Testudinata & unid. turtle & & & & & 1 & & 1 & 152 \\
\hline Kinosternidae & musk/mud turtle & & & & & & & & 4 \\
\hline Terrapene sp. & box turtle & & & & 2 & & & & 45 \\
\hline Colubridae & non-poisonous snake & & & & 3 & & & & \\
\hline Ave (small) & sm. bird & & & & & 2 & & & \\
\hline Ave (medium) & med, bird & & & & & & & 1 & \\
\hline Ave (large) & lg. bird & & & & & & & 1 & 2 \\
\hline Meleagris gallopavo & turkey & & & & 2 & 9 & & 6 & \\
\hline Mammalia (large) & lg. mammal & 1 & & & & 6 & & & \\
\hline Didelphis virginiana & opossum & & 3 & & 1 & & & & \\
\hline Leporidae & rabbit & & & 1 & 1 & 2 & & & \\
\hline Sylvilagus floridanus & eastern cottontail & & 5 & 5 & 6 & 6 & 2 & & \\
\hline Sylvilagus aquaticus & swamp rabbit & & 5 & 2 & 1 & 11 & & & \\
\hline Sciuridae & squirrel & & 6 & 2 & 5 & 16 & 1 & & \\
\hline Geomy:s sp. & pocket gopher & & & & & & & 2 & \\
\hline Procyon lotor & raccoon & & & & & 1 & & & \\
\hline Odocoilenss sp. & deer & & 21 & 23 & 24 & 172 & 29 & 26 & 85 \\
\hline & TOTAL & 2 & 42 & 33 & 49 & 228 & 32 & 37 & 289 \\
\hline \multicolumn{10}{|c|}{$\begin{array}{l}\text { NOTE: } \\
\text { "Cranial" includes skull and mandible fragments. } \\
\text { "Teeth" includes complete teeth and enamel fragments. } \\
\text { "Axial" includes sternibra, scapula, rib, vertebra, coracoid, clavicle, and pelvis fragments. } \\
\text { "Long bone" includes complete as well as fragmented limb bones. Most of these are long bone fragments. } \\
\text { "Podial" includes lower limb bones (carpals and tarsals). } \\
\text { "Phalanx" includes toe bone fragments. }\end{array}$} \\
\hline
\end{tabular}


Table 30. Preferred Habitat of Vertebrate Fauna from $41 \mathrm{SM} 325$.

\begin{tabular}{|c|c|c|}
\hline Scientific Name & Common Name & Habitat \\
\hline Osteichthyes & unidentified bony fish & aquatic \\
\hline Aplodinotus grunniens & freshwater drum & aquatic \\
\hline Anura & toad/frog & aquatic + bottomlands \\
\hline Kinosternidae & musk/mud turtle & aquatic \\
\hline Terrapene sp. & box turtle & woodlands + bottomlands \\
\hline Colubridae & non-poisonous snake & various \\
\hline Meleagris gallopavo & turkey & wooded edges \\
\hline Didelphis virginima & opossum & woodlands \\
\hline Sylvilagus floridanus & eastem cottontail & wooded edges \\
\hline Sylvilagus aquaticus & swamp rabbit & bottomlands \\
\hline Sciuridae & squirrel & woodlands + bottomlands \\
\hline Geomys sp. & pocket gopher & sandy \\
\hline Procyon lotor & raccoon & woodlands + bottomlands \\
\hline Odocolleussp. & deer & wooded edges \\
\hline
\end{tabular}

\section{Type A}

This is the only sharply pointed specimen in the collection (Figure 45a). Recovered from a fine screen sample taken in Feature 5, Unit 12, at $75-85 \mathrm{~cm}$ bs, it is manufactured from an unidentifiable large mammal bone fragment. It is finely crafted, but broken at mid-shaft and measures $3.5 \mathrm{~cm}$ in length. Pointed pieces such as this are generally called awls, but because of the triangular shape it is possible that this may be a hunting implement such as a projectile point.

\section{Type B}

These two specimens are polished deer paradigit metatarsals (see Figure 45b-c). Commonly called expediency tools, they are naturally shaped small, pointed bones. They are perfect ready-made awls. Although one is broken at the tip and the other is broken mid-shaft, they are about $5.0 \mathrm{~cm}$ long when complete. The surfaces are striated and polished from use-wear. One was recovered from Unit 1 (40 to $50 \mathrm{~cm}$ bs), and the other one came from Unit 8 (20 to $30 \mathrm{~cm}$ bs).

\section{Type C}

This category includes four blunt tool fragments. The blunt-tipped pieces are thought to function as small scrapers, for preparation of vegetal material, ceramics, basketry and textiles, or hide preparation. The one manufactured from a deer metapodial shaft fragment came from Unit 9 (20 to $30 \mathrm{~cm}$ bs). The other three are unidentifiable large mammal long bones (most likely deer), found in Unit 1 ( 30 to $40 \mathrm{~cm}$ bs, see Figure $45 \mathrm{~d}$ ), and Unit $12(0$ to 10 and 10 to $20 \mathrm{~cm}$ bs). Blunt awls are often referred to as flakers used in stone tool production. But lack of evidence of marring on the surface of these pieces from contact with stone disputes this suggestion. They were probably a multi-functional tool. possibly broken and reworked pointed awls. 
Table 31. Modified Faunal Specimens.

\begin{tabular}{|c|c|c|c|c|c|c|c|c|c|c|c|}
\hline TU & Depth $(\mathrm{cm} \mathrm{b}$ & cature & Type & Quantity & Taxon & Elem/Portion & Age & Burned & Modification & Wt/g & Comments \\
\hline 12 & $75-85$ & 5 & A & 1 & lg mam & unid & & b & sharp awl tip & 1.9 & FS \\
\hline 1 & $40-50$ & & $\mathrm{~B}$ & 1 & deer & paradigit & $\mathrm{imm}$ & not & awl "exped tool" & 0.7 & broken, polish \\
\hline 8 & $20-30$ & & B & 1 & deer & paradigit & & not & awl "exped tool" & 0.3 & polish \\
\hline 9 & $30-40$ & & C & 1 & deer & mtpod shft frgy & & not & blunt & 5.3 & \\
\hline 1 & $30-40$ & & $\mathrm{C}$ & 1 & $\lg$ mam & 1.b.trag & & not & blunt & 1.1 & \\
\hline 12 & $0-10$ & & $\mathrm{C}$ & 1 & Ig mam & I.b.frag & & $b$ & blunt & 0.5 & \\
\hline 12 & $10-20$ & & $\mathrm{C}$ & 1 & Ig mam & 1.b.frag & & $b$ & blunt & 0.9 & \\
\hline 11 & 28 & & $\mathrm{D}$ & 1 & deer & antler pedicle & & not & grinder & 41.5 & plot 5 \\
\hline 12 & $75-85$ & 5 & $\mathrm{E}$ & 1 & deer & mttar shft frg & & $\mathrm{b}$ & tool shaft & 3.5 & FS \\
\hline 12 & $20-30$ & & E. & 1 & Ig mam & 1.b.frag & & $b$ & tool shft & 1.5 & high polish \\
\hline 12 & $20-30$ & & $\mathrm{E}$ & 1 & swamp & fem shft & & $b$ & tool shet & 0.6 & high polish \\
\hline 9 & $20-30$ & & $\mathrm{~F}$ & 1 & turtle & shell frg & & not & disk & 0.5 & gnaw+polish \\
\hline 11 & $20-30$ & & $\mathrm{G}$ & 1 & deer & mtpod shft frg & & $b$ & scored & 1.8 & burn crack? \\
\hline 12 & $10-20$ & & $\mathrm{H}$ & 1 & deer & mtpod shft frg & & $b$ & chisel & 1 & frag only \\
\hline 11 & $20-30$ & & $H$ & 1 & lg mam & 1.b.frag & & not & spatulate frg & 0.5 & ground, polish \\
\hline 11 & $30-40$ & & 1 & 2 & deer & fem shft frg & & $b$ & mod frg & 2.9 & \\
\hline 11 & $30-40$ & & 1 & 1 & deer & mtpod shft frg & & b & $\bmod f r g$ & 0.9 & \\
\hline 11 & $30-40$ & & 1 & 1 & lg mam & l.b.frag & & $\mathrm{b}$ & mod frg & 1 & \\
\hline \multirow{9}{*}{\multicolumn{6}{|c|}{$\begin{array}{l}A=\text { large mammal awl tip } \\
B=\text { deer digit probable awl (expediency tool) } \\
C=\text { deer and large mammal "blunt awl" } \\
D=\text { rubbing or grinding tool } \\
E=\text { tool shaft fragments } \\
F=\text { disk } \\
G=\text { scoreditool in preparation } \\
H=\text { indeterminate function (chisel fragment }+ \text { spatulate fragment) } \\
H=\text { unidentified modified fragments }\end{array}$}} & \multirow{9}{*}{\multicolumn{3}{|c|}{$\begin{array}{l}\mathrm{b}=\text { burned } \\
\mathrm{lg}=\text { large } \\
1 . \mathrm{b}=\text { long bone } \\
\text { frag or frg = fragment }\end{array}$}} & & & \\
\hline & & & & & & & & & & & \\
\hline & & & & & & & & & & & \\
\hline & & & & & & & & & & & \\
\hline & & & & & & & & & & & \\
\hline & & & & & & & & & & & \\
\hline & & & & & & & & & & & \\
\hline & & & & & & & & & & & \\
\hline & & & & & & & & & & & \\
\hline
\end{tabular}




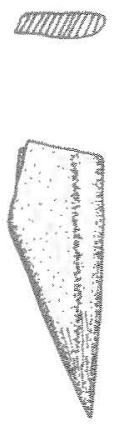

a

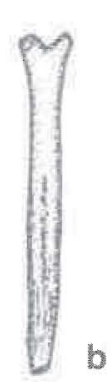

b

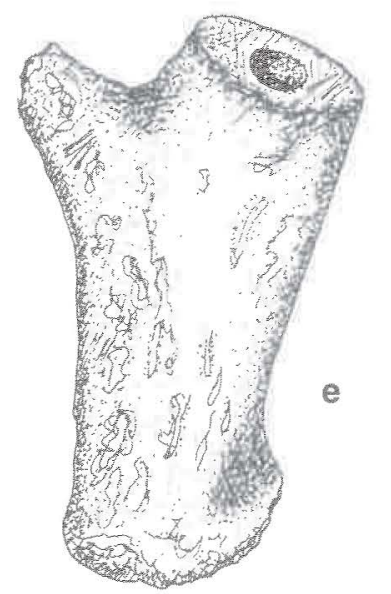

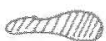

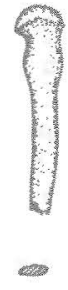

c

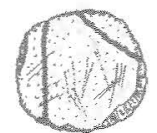

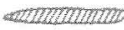

I

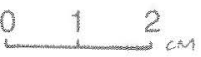

Figure 45. Modified bone from the Leaning Rock site: a, Type A; b-c, Type B; d, Type C; e, Type D; f, type F. Provenience: a, Unit 12, Feature 5.75-85 cm; b, Unit 1, 40-50 cm; c, Unit 8, 20-30 cm; d, Unit 1, 30-40 cm; e, Unit $11,28 \mathrm{~cm}$; f, Unit 9.20-30 cm. Drawings by LeeAnna Schniebs.

Type D

Manufactured from a shed antler pedicle, this specimen was recovered from Unit 11 at $28 \mathrm{~cm}$ bs (see Figure 45e). Possibly used as a rubbing or grinding tool, the antler shaft is bisected and the exposed surface is striated and highly polished. However, the edges of the worked surface are not rounded, as a pestle is rounded. It fits comfortably in the palm of the hand, and the rough surface of the shaft provides a firm grip. There is also a central hole in the distal end; perhaps this piece functioned as some sort of handle as well.

\section{Type E}

Three specimens are recorded as broken tool shaft fragments. Two pieces came from Unit 12,20 to $30 \mathrm{~cm}$ bs. The large mammal long bone fragment is manufactured from a dense piece of bone and is striated and highly polished. The swamp rabbit femur shaft fragment is split longitudinally, and the edges are rounded and polished. The third artifact is from a fine screen sample taken in Feature 5, Unit $12(75$ to $85 \mathrm{~cm}$ bs). It was manufactured from a deer metatarsal shaft, and is split longitudinally on the medial and lateral sides. The edges are rounded, similar to the swamp rabbit artifact. 


\section{Type F}

A possible ornament or game piece was recovered from Unit 9,20 to $30 \mathrm{~cm}$ bs (see Figure 450 ). It is a small piece of turtle shell that is circular in shape and polished around the edges. Although it is rodent gnawed, it is believed that the gnawing occurred post-depositionally.

\section{Type G}

This artifact from a deer metapodial shaft appears to have been transversely engraved or scored, but examination revealed these even, parallel lines are probably slight fractures from burning. However, it is longitudinally scored down the anterior groove, a method used in beginning tool manufacture preparation common to the deer metapodial.

\section{Type H}

One broken chisel-shaped fragment was recovered from Unit 12,10 to $20 \mathrm{~cm}$ bs. It is manufactured from a deer metapodial shaft. The chisel is thought to be used to split or process wood or other vegetal materials. A broken spatula-like fragment from Unit 11,20 to $30 \mathrm{~cm}$ bs, is an unidentifiable large mammal bone. The unbroken working edges on both pieces are shaped, ground, and polished. Fragmentation prevents specific identification of tool function.

\section{Type I}

Four unidentifiable fragments comprise this category. They are broken pieces of unknown tool types, but the bone surfaces are striated and polished. Two specimens are deer femur shafts, one is a deer metapodial shaft, and the third is an unidentifiable large mammal long bone. All were recovered from Unit 11,30 to $40 \mathrm{~cm}$ bs.

\section{SUMMARY OF THE FAUNAL REMAINS ANALYSIS}

The Leaning Rock Site faunal collection is well preserved and generally in good condition, despite rodent gnawing on many of the bones. Approximately $67 \%(\mathrm{n}=477)$ of the identifable specimens are burned (Table 32). Burning can be evidence of trash disposal as well as indicative of food processing or tool manufacturing activities. Bumed unidentifiable bones were not counted.

The purpose of the faunal analysis was to determine the animal subsistence practices of the site residents, specifically the utilization of avallable natural resources in the area. Archeological remains indicate the middle Caddo folks at Leaning Rock relied both on the hunting and gathering of natural resources as well as the growing of maize. The faunal sample demonstrates that hunting activities played an important role in the diet at Leaning Rock, although the paucity of arrow points or lithic artifacts in general leaves open the question of how the game was procured. Previous investigations at other Caddo sites in the area have found similar animal resource utilization patterns as well as the use of the same general range of species. Environmental areas exploited include aquatic and riparian habitats, forests, and open meadows with wooded edges. The modified bone fragments from the Leaning Rock site reveals further evidence of site activities such as plant processing as well as animal procurement and subsequent processing. 
Table 32. Summary of Burned Faunal Specimens.

\begin{tabular}{|c|c|c|c|}
\hline Scientific Name & Common Name & Not Burned & Burned \\
\hline Osteichthyes & unidentified bony fish & 7 & \\
\hline Aplodinotus grunniens & freshwater drum & & 1 \\
\hline Anura & toad/frog & 2 & \\
\hline Testudinata & unidentified turtle & 20 & 134 \\
\hline Kinostemidae & musk/mud turtle & 2 & 2 \\
\hline Terrapene sp. & box turtle & 16 & 31 \\
\hline Colubridae & non-poisonous snake & 3 & \\
\hline Ave & small bird & 2 & \\
\hline Ave & medium bird & & 1 \\
\hline Ave & large bird & 3 & \\
\hline Meleagris gallopavo & turkey & 10 & 7 \\
\hline Mammalia & large mammal & 2 & 5 \\
\hline Didelphis virginiana & opossum & 4 & \\
\hline Leporidae & rabbit & 2 & 2 \\
\hline Sylvilagus floridanus & eastern cottontail & 16 & 8 \\
\hline Sylvilagus aquaticus & swamp rabbit & 16 & 3 \\
\hline Sciuridae & squirrel & 28 & 2 \\
\hline Geomys sp. & pocket gopher & & 2 \\
\hline Procyon lotor & raccoon & & 1 \\
\hline \multirow[t]{2}{*}{ Odocoileus sp. } & deer & 102 & 278 \\
\hline & TOTAL & 235 & 477 \\
\hline
\end{tabular}

\section{MOLLUSCA FROM THE LEANING ROCK SITE (41SM325), SMITH COUNTY, TEXAS}

\section{Jesse Todd}

The following discussion presents the results of the analysis of the gastropoda (snails) and pelecypoda (freshwater mussels) from the Leaning Rock site (4ISM325) (Appendix II). Most of the freshwater mussels were fragmented and unidentifiable. However, some of the fragments were quite large, indicating the mussels they came from were large and probably from a stable environment such as the Sabine River. Several freshwater mussel fragments ranged from being burned black, indicating intensive heating, to gray from light heating. It is doubtful that the mussels were intensively burned to open the mussels; therefore, these shells were probably discarded into a fire after use. The mussels were probably steamed, which would be indicated by the gray color of the shell. Also based upon the amount of shell present, it was not a major subsistence food at the site and may have been incidental to gathering other aquatic resources. None of the identified freshwater mussels appeared to have been decorated or used as a tool.

The gastropoda consist of Helicina orbiculata, Glyphylinia (Retinella) indentata, and Linisa (Polygyra) texasiana. These snail shells were recovered from $20-30 \mathrm{~cm}$ bs and indicate the presence of year round vegetation with forest debris. 
Six species of freshwater mussels were identified from the excavations and consist of Fusconaia flava (n=4), Lampsilis teres $(\mathrm{n}=1)$, Lampsilis hydiana $(\mathrm{n}=1)$, Quadrula apicutana $(\mathrm{n}=1)$, Quadrula mortoni $(\mathrm{n}=1)$ and Tritogonia verncosa $(n=4)$. The identification of the mussel species Tritogonia verrucosa was difficult due to the amount of weathering present (Figure $46 \mathrm{a}-\mathrm{e}$ ). The species was identified using the general shell outline, the pseudocardinal teeth, the anterior adductor scar, and the inflation of the shell in the umbo area.

Seven of the valves were taken from Unit 12. Feature 5, and along with the amount of fragments recovered from the test unit, indicates the greatest concentration area for the site. The sizes range from small to quite large. The variety of species indicates that no one species was targeted and the differences in size indicate that age selection was not important. Also, based upon the seasonal distribution of the species, it is unlikely that one species was targeted during a specific time period. The Fusconala flava mussel shell recovered from Unit 12 , Feature $5(75-85 \mathrm{~cm}$ bs), has a nick (see Figure $46 \mathrm{e}$ ) in the posterior portion of the shell that is similar to those recovered from the Shanklin site, which is a historic Native American site in Wharton County, Texas (Hudgins 1984:47). Hudgins (1984:37) could not provide an answer to why 30 percent of the shells were notched and neither can 1 .

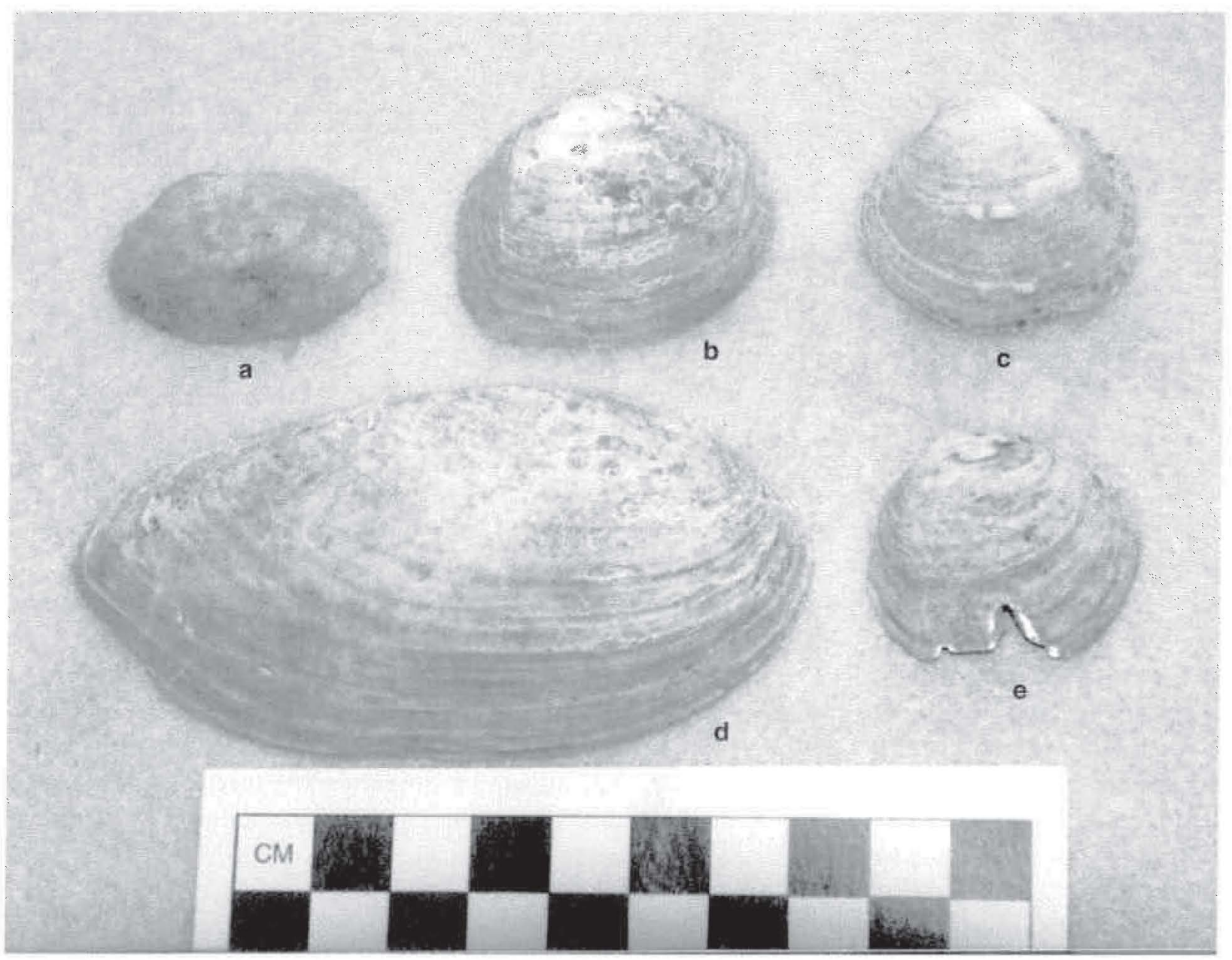

Figure 46. Examples of freshwater mussel shells from the Leaning Rock site: a, Lampsih hvdiana, b, Lampsils teres; ${ }$,

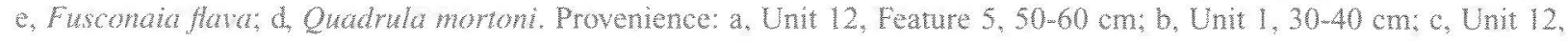
Feature $5,30-40 \mathrm{~cm}$, Unit $1,50-60 \mathrm{~cm}$; e. Unit 12. Feature $5,75-85 \mathrm{~cm}$ 
Environmentally, the freshwater mussel species from Texas are generalists; however, some paleoenvironmental statements can be made. Both Fusconala flava and Lampsilis teres cannot tolerate deep, shifting sands. The presence of Tritogonia verrucosa indicates moderate to good quality water, meaning the amount of sediment in the stream ranged from a medium to a light load. Also, the water was well-oxygenated and riffes were present. The shape of the Fusconaia fleva shells are compressed, except for one that borders on being inflated, which indicates they were taken from a small river. Lampsilis hydiana is usually associated with a riverine environment; however, I have taken shells from Denton Creek in North Central Texas, which is a large creek, but not a riverine environment.

Three streams are present within the general vicinity of the study area: Jackson Creek, Prairie Creek, and the Sabine River. Jackson Creek is a tributary to Prairie Creek and was dry in 2006 and is never more than a small branch (Mark Walters, 2006 personal communication). It is doubtful that the mussel shells were taken from Jackson Creek. Probably, all the freshwater mussel species were taken from the Sabine River, especially when one looks at the large size of the shells and the fragments. However, small shells are present and could have been taken from Prairie Creek, possibly in the vicinity of where the creek flows into the Sabine River.

\section{EPILOGUE}

This epilogue will finish this article on the Leaning Rock site. In the meantime I made another visit just the other day (July 2007) to Leaning Rock, as it is only a couple of miles up the road from the house. Across the road from where I turn into the pasture leading to Leaning Rock is a lone gravestone dating to 1880 , marking the influx of Europeans into this area. At the gate are daffodils marking the location of a black tenant house dating to the turn of the 20th century, another remnant of the past. Arriving at the Leaning Rock site, I notice that the pasture (improved pasture and beef cattle production only becoming prevalent since the 1950 s) is greening up due to recent rains, although the landowner has not restocked from the droughty conditions that prevailed during fieldwork there. Walking around on the site no one would guess that this was home to a different people from a different time. This to me is what makes archeology so interesting. As a kid I spent my time on Jackson Creek and surrounding creeks trapping, hunting, and exploring. Later I made my livelihood from working these soils. But my way of life is also changing and will soon be a faded memory.

I would give anything to have parted the bushes at the time the Leaning Rock folks were living here to get a glimpse of how they lived. We learned from our meager investigations at Leaning Rock (Figure 47) that people had been traveling across and living at this location for thousands of years. Were the Caddo that occupied the Leaning Rock site during Middle Caddo period times (Ca. A.D. 1200-1400) the product of a gradual evolution of a specific group of people that had lived in this area for generations, or, as I suspect, were there movements of Caddo peoples into and out of the area, with more of a punctuated settlement pattern? Investigations in the area of the Leaning Rock site indicate a modest Woodland period occupation preceding the advent of the Caddo culture, though it is difficult to tie the two together or relate them culturally or genetically. There are few Early Caddo sites (i.e., predating ca. A.D. 1200) nearby, but again it is hard to document specific cultural relationships between Early Caddo and Middle Caddo peoples that would be indicative of cultural transitions and gradual cultural changes. For some reason, or perhaps for multiple reasons, there appears to be a florescence of Caddo culture around the period of time that Leaning Rock was occupied. Sites of this time period are more visible on the landscape and seem to have been more intensively used, at least based on the midden deposits left at sites such as Leaning Rock. I would like to think that life for the Caddo at Leaning Rock was good, judging from the remains of the many cooking pots dumped around the hearth area, and there were no apparent signs of stress or conflict in the archeological record here or at other sites in the area. Yet following the occupation at sites 
like Leaning Rock, around the mid-15th century A.D., this area appears to have been abandoned by the Caddo, with no concrete archeological evidence of Caddo sites dating to later than the Middle Caddo period. It would be interesting to know if the Leaning Rock folks had any premonition or forewarning that their way of life on Jackson Creek was to experience a radical transformation. Indeed, I wonder if there are lessons to be learned at Leaning Rock that would profit our own society, by teaching us what shaped the world we live in (and how we understand it) and what might shape our future.

It has been difficult to trace where the Leaning Rock Caddo folks went. However, wherever the Leaning Rock folks went and for whatever reason, I hope their journey was a happy one.

\section{ACKNOWLEDGEMENTS}

This article would have never happened without the contributions of many friends and colleagues. It is heartening to know that these special people cared enough for the advancement of Caddo archeology to donate their time and energy to this project. My heartfelt thanks to those unpaid contributors, who include Dr. Harry Shafer, Dr. Phil Dering, Jesse Todd, Chester P. Walker, and lastly Dr. Timothy K. Perttula, who not only contributed the sections on decorated sherds and plain rims, but also edited the rest of the article, and donated an AMS date on a charred maize cob.

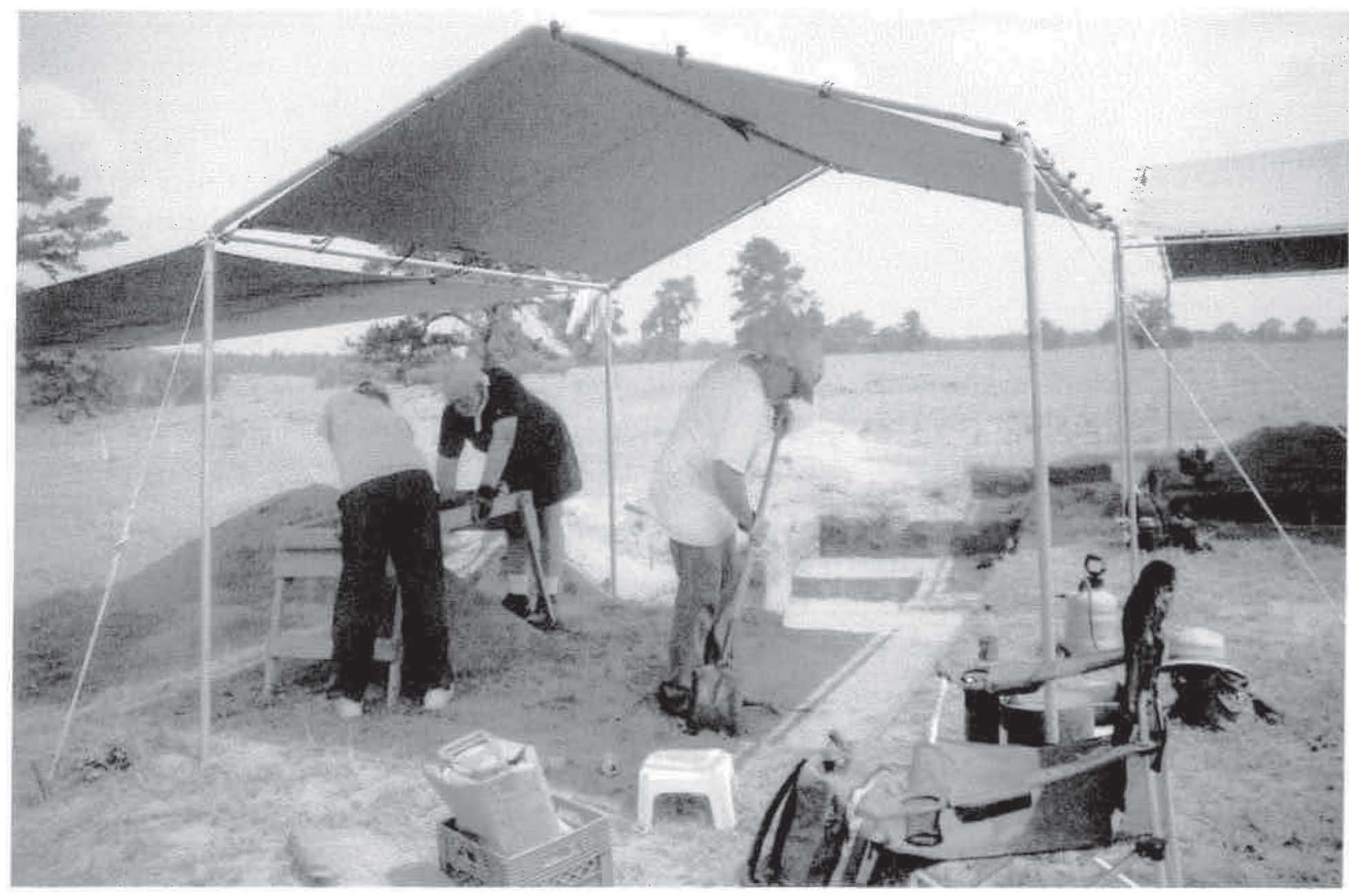

Figure 47. Excavations at the Leaning Rock site. Participants, from left to right, are Brittainy Tidwell, Michael Bartley, and Bryan Boyd. 
Other folks who donated their time and expertise include Shawn Marceaux, Clay Schultz, Bryan Boyd, Susan Hollyday and her granddaughter Brittainy Tidwell, Dona Stone, Kelly Doharty, and Michael Bartley. Also helping were Dr. Tom Middlebrook, his wife Sylvia and daughters Holly and Emily, and members of his "Action" team: Dylan Baggett, Joanna McMurry, Drew Hall, and Anne and Kip Tindall. My granddaughter Madeline Walters Weikel helped with excavations and the washing and sorting of artifacts. Bo Nelson deserves special thanks for his help with the excavation of Feature 1. He also took the photographs of artifacts included in this article.

Thanks are extended to the Donor's Fund Trustees and the Board of Directors of the Texas Archeological Society for funds to study the fauna from Leaning Rock. LeeAnna Schniebs completed the faunal analyses.

I thank Robert Brooks, owner of Leaning Rock, for permission to conduct excavations in his pasture.

In conclusion, I would like to thank my wife Sandra for putting up with this obsession, including the capital outlays that could have been used around the house and for boarding occasional itinerant archeologists.

Perttula thanks Bo Nelson for taking the many fine photographs of vessel sherds from the Leaning Rock site, and Sandra Hannum for preparing a number of figures. He would also like to thank John Miller for sharing his thoughts concerning the prehistoric Caddo use of bone temper. Finally, he appreciates Mark Walters allowing him the opportunity to study this important prehistoric Caddo ceramic assemblage.

Ferguson, Cecil, and Glascock acknowledge Ben Zalaski for his role in preparing the INAA samples for irradiation. The INAA project work was supported in part by NSF grant BCS-0504015 to the Archaeometry Laboratory at the University of Missouri Research Reactor. 


\section{REFERENCES CITED}

Banks, L. D.

1990 From Mountain Peaks to Alligator Stonachs. Memoir No. 4. Oklahoma Anthropological Society, Norman.

Banks, L. D. and J. Winters

1975 The Bentsen-Clark Site, Red River Couny, Texas: A Preliminary Report. Special Publication No. 2. Texas Archeological Society, San Antonio.

Baxter, M.J.

1992 Archaeological uses of the biplot a neglected technique? In Computer Applications and Quantitative Methods in Archaeology, 1991, edited by G. Lock and J. Moffett, pp. 141-148. BAR International Series S577. Tempvs Reparatvm, Archacological and Historical Associates, Oxford.

1994 Exploratory Multivariate Analysis in Archatology. Edinburgh University Press. Edinburgh.

Baxter, M. J. and C. E. Buck

2000 Data Handling and Statistical Analysis. In Modern Analytical Methods in An and Archacology, edited by E. Ciliberto and $\mathrm{G}$. Spoto, pp. 681-746. John Wiley and Sons, Inc., New York.

Beach, M. A. and C. S. Causey

1984 Bone Artifacts from Arroyo Hondo Pueblo. In The Fawnal Remains From Arroyo Hondo Pueblo, New Mexico: A Study in Short-Term Subsistence Change, by R. W. Lang and A. H. Harris. Arroyo Hondo Archaeological Series, Vol. 5. School of American Research Press, Santa Fe.

Behler, J.L.

1995 National Audubon Society Field Gudie to North American Reptiles and Amphibians. Chanticleer Press, New York.

Bevan, B. M

1983 Electromagnetics for Mapping Buried Earth Features. Joumal of Field Archaeology 10:47-54.

1998 Geophysical Exploration for Archaeology: An Introduction to Geophysical Exploration. Special Report No. 1. Midwest Archeological Center, Lincoln, Nebraska.

Bieber, A. M. Jr., D. W. Brooks, G. Harbottle, and E. V. Sayre

1976 Application of multivariate techniques to analytical data on Acgean ceramics. Archaeometry 18:59-74.

Bishop, R. L. and H. Neff

1989 Compositional data analysis in archaeology. In Archaeological Chemistry W, edited by R, O. Allen, pp. $576-586$. Advances in Chemistry Series 220. American Chemical Society, Washington, D.C.

Bishop, R. L., R. L. Rands, and G. R. Holley

1992 Ceramic compositional analysis in archaeological perspective. In Advances in Archaeological Method and Theory, Vol. 5, edited by M. B. Schiffer, pp. 275-330. Academic Press, New York.

Brewington, R. L., J. E. Dockall, and H. J. Shafer

1995 Ancheology of $41 \mathrm{MXS}$ : A Late Prehistoric Caddoan Hamlet in Morris County. Texas. Reports of Investigations No. 1. Center for Enviromental Archaeology, Texas A\&M University, College Station.

Bruseth, J. E. and T. K. Perttula, with contributions by G. J. Fritz and B. C. Yates

2006 Archeological Investigations at the Hudnall-Pirtle Site (4IRK4): An Early Caddo Mound Center in Northeast Texas. Caddo Archeology Journal 15:57-158.

Bruseth, J. E, and B. Pierson

2004 Magnetometer Survey at the George C. Davis Site (41CE19). Cument Archeology in Texas 6(1):7-9.

Burt, W. H. and R. P. Grossenheider

1980 A Ficld Guide to the Mammals, Peterson Field Guide Series. 3rd edition, Houghton Mimin Company, Boston. 
Campbell, T. N.

1936 A Study of Omamentation in the Pottery of Prehistoric East Texas, with Special Attention given to Designs. Master's thesis, Department of Anthropology, The University of Texas at Austin.

Chaplin, R. E.

1971 The Study of Animal Bones from Archaeological Sites. Seminar Press, New York.

Clay, B. R.

2006 Conductivity Survey: A Survival Manual. In Remote Sensing in Archaeology: An Explicitly North American Perspective, edited by J. K. Johnson, pp. 79-107. University of Alabama Press, Tuscaloosa.

Cogswell, J.W., H. Neff, and M. D. Glascock

1998 Analysis of shell-tempered pottery replicates: Implications for provenance studies. American Antiquity $63(1): 63-72$.

Collins, H. H. Jr.

1959 Complete Field Guide to American Wildlife. Murray Printing Company, Forge Village, Massachusetts.

Conant, R.

1975 A Field Guide to Reptiles and Amphibians of Eastern and Central North America. 2nd Edition. Peterson Field Guide Series. Houghton Mifflin Company, Boston.

Conyers, L. B.

2004 Ground-Penetrating Radar. AltaMira Press, Walnut Creek, California.

Conyers, L. B. and J. Lucius

1996 Velocity analysis in archaeological ground-penetrating radar studies. Archaeological Prospection 3:25-38.

Creel, D. G., D. Hudler, S. M. Wilson, T. C. Schultz, and C. P. Walker

2005 A Magnetometer Survey of Caddoan Mounds State Historic Site. Technical Report 51. Texas Archeological Research Laboratory, The University of Texas at Austin.

Culleton, B. I.

2006 Implications of a freshwater radiocarbon reservoir correction for the timing of late Holocene settlement of the Elk Hills, Kern County, California. Joumal of Archaeological Science 33:1331-1339.

Dalan, R. A.

2006 Magnetic Susceptibility. In Remole Sensing in Archaeology: An Explicitly North American Perspective, edited by J. K. Johnson, pp. 161-203. University of Alabama Press, Tuscaloosa.

David, A.

1995 Geophysical Survey in Archaeological Field Evaluation. Ancient Monuments Laboratory, English Heritage Society, London.

Davis, W. B.

1978 The Mammals of Texas. Bulletin No. 41, revised. Texas Parks and Wildlife Department, Austin.

Descantes, C., R. J. Speakman, and M. D. Glascock

2003 Letter Report to Timothy K. Pertula with enclosed figures and tables, September 3, 2003. University of Missouri Research Reactor, Columbia.

Diehl, M.

2003 Prehistoric Subsistence Strategies and the Macrobotanical Assemblage. In Hohokam Farming on the Salt River Floodplain, edited by T. K. Henderson, pp. 211-230. Anthropological Papers No. 42, Center for Desert Archaeol. ogy, Tucson, and Anthropological Papers No.9, Pueblo Grande Museum, Phoenix.

Duffield, L. F.

1963 The Wolfshead Site: An Archaic-Neo-American Site in San Augustine County, Texas. Bulletin of the Texas Archeological Society 34:83-141. 
Farrelly, D.

1984 The Book of Bamboo: A Comprehensive Guide to This Remarkable Plant, Its Uses, und Its History. Sierra Club Books, San Francisco.

Ferguson, J. R, and M. D. Glascock

2006 Instrumental Neutron Activation Analysis of Caddoan Pottery and Clay Samples from Texas and Louisiana. Report prepared for Timothy K. Pertula. September 14,2006.

Frederick, C. and J. T. Abbott

1992 Magnetic Prospection of Prehistoric Sites in an Alluvial Environment: Examples from NW and West-Central Texas. Joumal of Field Archaeology 19(2):139.153.

Gaffney, C. and J. Gater

2003 Revealing the Buried Past: Geophysics for Archaeologists. Tempus Publishing Ltd., Stroud, United Kingdom.

Girath, J.S.

1995 The Chipped Stone Collection: Technological, Functional, and Typological Analysis. In: The Deshazo Site, Nacogdoches Connty, Texas, Vol. 2. Arlfacts of Native Mantifacture, edited by D. A. Story, pp. 33-156. Studies in Archeology 21 . Texas Archeological Research Laboratory, The University of Texas at Austin.

Glascock. M. D.

1992 Characterization of archaeological ceramics at MURR by neutron activation analysis and multivariate statistics. In Chemical Characterization of Ceramic Pastes in Archaeology. edited by H. Neff, pp. $11-26$. Prehistory Press, Madison. Wisconsin.

Gleick, P. H.

1996 Basic water requirements for human activities: meeting basic needs. Water Intemational $21: 83=92$.

Harbottle, G.

1976 Activation andysis in archacology. Radiochemistry 3:33-72.

Hart, J.P.

1982 An Analysis of the Aboriginal Ceramics from the Washington Square Mound Site, Nacogdoches County, Texas. Master's thesis, Department of Anthropology, Northeast Louisiana University, Monroe.

Hatherly, D. T.

1993 Soil Survey of Smith County, Texas. United States Department of Agriculture, Soil Conservation Service, in cooperation with the Texas Agricultural Experiment and the Texas State Soll and Water Conservation Board.

Holliday, V.T.

1992 Soils in Archaeology. Smithsonian Institution Press, Washington and London.

2004 Soils in Archaeological Research. Oxford University Press, New York.

Howells, R. G., R. W. Neck. and H. D. Murray

1996 Freshwater Mussels of Texas. Texas Parks And Wildife Press, Austin.

Huckell, L.

2002 Paleocthnobotany. In Tonto Creek Archaeological Project Artifact and Environmental Analyses. Volume 2: Stone Tool and Subsisience Sudies, edited by J. 1. Clark, pp. 643.709. Anthropological Papers No. 23. Center for Desert Archaeology, Tucson

Hudgins, J. D.

1984 A Historic Indian Site in Wharton County, Texas. Bulletin of the Texas Archeological Society $55: 29-51$.

Kidder. A. V.

1932 The Arifacts of Pecos. Yale Unversity Press, Andover, Massachusetts.

Kraus, E. H. W. F. Hunt, and L. S. Ramsdell

1951 Minerdogy. McGraw-Hill Book Company, Inc., New York. 
Kvamme, K. L.

2003 Geophysical Surveys as Landscape Archacology. American Antiquitw 68:435-457.

2006 a Integrating Multidimensional Geophysical Data. Archaeological Prospection 13:57-72.

2006b Magnetometry: Nature's Gift to Archacology. In Remote Sensing in Archaeology: An Explicith Norih American Perspective, edited by J. K. Johnson, pp. 205-233. Universily of Alabama Press, Tuscaloosa.

$2006 c$ Data Processing and Presentation. In Remote Sensing in Archaeology: An Explicitly North American Perspective, edited by J. K. Johnson, pp. 235-250. University of Alabama Press, Tuscaloosa.

Kvamme, K. L., J. K. Johnson, and B. S. Haley

2006 Multiple Methods Surveys: Case Studies. In Remote Sensing in Archaeology: An Explicitly North American Perspecive. edited by J. K. Johnson, pp. 251-267. University of Alabama Press, Tuscaloosa.

Leese, M. N. and P. L. Main

1994 The efficient computation of unbiased Mahalanobis distances and their interpretation in archaeometry. Archaeometry $36: 307-316$.

Leopold, L. B., M. G. Wolman, and J. P. Miller.

1965 Fluvial Processes in Geomorphology, Dover Publications, Inc., New York.

Lipo, C. P., R. C. Dunnell, and D. O. Larsen

2004 Studying the Evolution of Complex Societies: Recent Geophysical Studies in the Central Mississippi Valley. The Missouri Archaeologist 65:68-106.

Lockhart. J. J.

2006 Multi-sensor archaeogeophysics in disparate physiographic regions of Arkansas. Lecture in University of Oklahoma Anthropology Graduate Student Association Lecture Series, Norman.

2007 Prehistoric Caddo of Arkansas: A Multiscalar Examination of Past Cultural Landscapes. Ph.D. dissertation, Department of Anthropology, University of Arkansas, Fayetteville.

Lockhart, J. J. and T. J. Green

2006 The Current and Potential Role of Archaeogeophysics in Cultural Resource Management in the United States. In Remote Sensing in Archacology. An Explicitly Norh American Perspective, edited by 1. K. Johnson, pp. 18 m2. University of Alabama Press, Tuscaloosa.

Lucius, J. H. and M. H. Powers

2002 GPR data processing computer sofware for the PC. Open File Report 02-166. United States Geological Survey, Washington D.C.

Mardia, K. V., J. T. Kent, and J. M. Bibby

1979 Multivariate Analysis. Academic Press, London.

Miksicek, C.

1994 Deceptive Barrenness: Archaeobotanical Material from the Schuk Toak Project Area. In Archaeological Studies of the Avra Valley, Arizona: Excavations in the Schuk Toak District. Volume 2: Scientific Studies and Interpretations. edited by A. Dart, pp. 243-266. Anthropological Papers No. 16. Center for Desert Archaeology, Tucson.

Milsom, J.

2005 Field Geophysics: The Geological Field Guide Series, 3rd edition. Wiley, West Sussex, United Kingdom.

Munzel, S.

1986 Quantitative Analysis and the Reconstruction of Site Patterning. Paper presented at the Vth International Conference of the International Council for ArchaeoZoology, August 25-30, Bordeaux, France.

Nef, $\mathrm{H}$

1992 Introduction. In Chemical Characterization of Ceramic Pastes in Archaeology, edited by H. Nerf, pp. 1 -10. Prehistory Press, Madison, Wisconsin.

1994 RQ-mode principal components analysis of ceramic compositional data. Archazometry 36:115-130.

2000 Neutron activation analysis for provenance determination in archaeology. In Modern Analytical Methods in Art and Anchaeology, edited by E. Ciliberto and G. Spoto, pp. 81-134. John Wilcy and Sons, Inc., New York. 
2002 Quantitative techniques for analyzing ceramic compositional data. In Ceramic Sontce Determination in the Greater Southwest, edited by D. M. Glowacki and H. Neff, pp. 15-36. Monograph 44. Cotsen Institute of Archacology. UCLA, Los Angeles.

Newcomb. W.W., It.

1993 The Indians of Texas from Prehistoric to Modem Times. 2nd Edition. University of Texas Press, Austin.

Pertula, T. K.

2001 a The Analysis of Caddo Ceramics from Four Sites in Rusk County, Texas. In National Register Eligibility Testing (4IRK107. 4IRK240, 4IRK242.41RK243, 4IRK276, and 4IRK286) and Additonal Testing (4IRK243) Investigahons within the Oak Hill Mine, Permit No. 46 , Rusk Coumty: Texas. by D. L. Sherman, T. K. Perttula, S. S. Victor, and M. A. Nash, pp. 95-115. Document No. 000237. PBS\&J, Austin.

20016 The Caddo Ceramics from Additional Investigations at 41RK243. In National Register Eligibility Testing (4IRK I07, 4IRK240,4IRK242, 4IRK243, 41RK276, and 41RK286) and Additional Testing (41RK243) Investigations within the Oak Hill Mine, Permit No. 46, Rusk County, Texas, by D. L. Sherman, T. K. Pertula, S. S. Victor, and M. A. Nash, pp. 116-125. Document No. 000237. PBS\&J. Austin.

2002 Atchaeological Evidence for the Long-Distance Exchange of Caddo Indian Ceramics in the Southern Plains, Midwest, and Southeastern United States. In Geochemical Evidence for Long-Distance Exchange, edited by $M$. D. Glascock, pp, 89-107. Bergin and Garvey, Westport, Connecticut.

2004 a The Prehistoric and Caddoan Archeology of the Northeastern Texas Pineywoods. In The Prehistory of Texas, edited by T. K. Pertula, pp. 370-407. Texas A\&M University Press, College Station.

2004 b Decorated Ceramics. In The Oak Hill Village Site (41RK214). Rusk County, Texas, by R. Rogers and T. K. Perttula, pp. 209-271. Document No. 030083. PBS\&J, Austim.

Pertula, T. K. and B. Nelson

2003 The Nawi haia ina Site (4IRK170): Archeological lnvestigations in the City of Hendersons Southride Wastewater Treatment Plant, Rusk County. Texas. Report of Investigations No. 51 . Archeological \& Environmental Consultants, LLC, Austin.

2004 Woodland and Caddo Archeology at the Broadway or Kanduts' 'ah Kuhnihdahahdisa' Site (4ISM273) on the City of Tyler-Lake Palestine WTP Project, Smith County, Texas. Report of Investigation No. 50. Archeological \& Environmental Consultants, LLC, Austin.

2007 Archeological Survey Investigations and Test Excavations at 4 /CE354 at the North and South Lake areas of the H.R.C. Cherokee Tree Farm. L.P. Project, Cherokee County, Teras. Report of Investigations No. 80. Archeological \& Environmental Consultants, LLC. Austin.

Pertula, T. K, and R. Rogers

2007 The Evolution of a Caddo Community in Northeastem Texas: The Oak Hill Village Site (41RK214), Rusk County, Texas. Americun Antiquity $72(1): 71-94$.

Perttula, T. K. and M. Walters

2007 Texas Archeological Society Academy 101 Field Survey Day, Februany 19, 2005. Smith Coumtv, Texas. Texas Archeological Society, San Antonio.

Perttula, T. K., B. Nelson, and T. C. Schultz

2002 Archaeological Survey of the U.S. 27\%. Mount Pleasant Loop, Titus County, Texas for the Texas Department of Transportation. Archeological \& Envirommental Consultants, LLC, Austin.

Petruso, $K$. and J. Wickens

1984 The Acorn in Aboriginal Subsistence in Eastern North America: A Report on Miscellaneous Experiments. In Experiments and Observations on Aboriginal Wild Plant Food Utilization in Eastern North America, edited by P. J. Munson, pp. 360-378. Prehistory Research Series 6(2). Indiana Historical Society. Indianapolis.

Rice, P. M.

1987 Pottery Analysis: A Sourcebook. University of Chicago Press, Chicago.

Robbins. C. S. B. Brum, and H. S. Zim

1983 A Guile to Field ldentification: Birds of North America. Revised edition by Western Publishing, Racine, Wiscon$\sin$ 
Rogers, R. and T. K. Pertula

2004 The Oak Hill Village Site (4lRk214), Rusk Comty, Texas. Document No. 030083. PBS\&I, Austin.

Rye. O.S.

1981 Potten Technologw: Princinles und Reconstruction. Taraxacum, Washington, D.C.

Sayre, E. V.

1975 Brookhaven Procedures for Statstical Analves of Multivalate Archaeometric Data. Report BNL-23128. Brookhaven National Laboratory. New York.

Schambach, F. F.

2001 A Prelminary Report on the 2001 Investigations by the Arkansas Archeological Survey and the Arkansas Archeological Society at the Grandview Prairie Wildife Management Area, Hempstead County, Southwest Arkansas. Field Notes 301:5 11. Newsletter of the Arkansas Archeological Socicty.

2002 The Grandview Archeological Project: The Arkansas Archeological Survey/Arkansas Archeological Society's 2002 Field Season at the Grandview Prairie Wildife Management Area, Columbus, Arkansas. Field Notes 308:3-8. Newsletter of the Arkansas Archeological Society.

Schambach. F. E. and J. J. Lockhart

2003 The 2001-2002 Investigations by the Arkansas Archeological Survey and the Arkansas Archeological Society at the Tom Jones Site (3HE40), a Late 4 th-Early 15 th Century Caddo Mound Group in Southwest Arkansas. Paper presented at the 45th Anmual Caddo Conlerence, Arkadelphia, Arkansas.

Schmidly, D. $J$

1983 Texas Mammals East of the Batcones Funl Zone. Texas A\&M Univarsity Press, College Station.

Shafer. H. J.

1973 Lithic Technology at the George C. Davis Site, Cherokee County, Texas. Ph.D. dissertation, Department of Anthropology, The University of Texas at Austin.

2003 Mimbres Archaeology at the NAN Ranch Ruin. University of New Mexico Press, Albuquerque.

2007 Leaning Rock Site (4ISM325) Lithics. Caddo Archeology, Journal 16:57-70.

Solis, Fr. G.J. de

1931 Diary of a Visit of Inspection of the Texas Missions Made by Fray Caspar José de Solis in the year 1767-1768. Translated by M. K. Kress. Souhweriem Historical Quarterly 35:28-76.

Somers, $L$

2006 Resistivity Survey. In Remote Sensing in Archaeology: An Explicitly North American Perspective. edied by J. K. Johnson, pp. 109-129. University of Alabama Press, Tuscaloosa.

Steponaitis, V.. M. J. Blackman, and H. Nef?

1996 Large-scale compositional pattems in the chemical composition of Mississippian pottery. American Amiunity $61: 555-572$.

Studer, J. M.

1982 Archatc Pebble Core Reduction Technology in East Texas: The lcy Eve Example. Papers in Anthropology No. 3. Stephen F. Austin State University. Nacogdoches.

Suhm, D. A. and E. B. Jelks (editors)

1962 Hundbook of Texas Archeology: Type Descriptions. Special Publication No. 1, Texas Archeological Society, and Bulletin No. 4, Texas Memorial Museum.

Suhm, D. A. A. D. Krieger, and E. B. Jelks

1954 An Introductory Handbook of Texas Archeology. Bulletin of the Texas Archeological Society $25: 1.562$.

Teltser. P.A.

1993 An Analytic Strategy for Studying Assemblage-Scale Ceramic Variation: A Case Study from Southeast Missouri. American Antiquity 58(3):530-543. 
Tous, $G$.

1930 The Espinosa-Olivares-Aguirre Expedition. Preliminary Studies of the Texas Catholic Historical Soctery 1(4): $2-24$.

Turner E. S. and T. R. Hester

1999 A Field Guide to the Stone Artifacts of Texas Indians. Gulf Publishing Company, Houston.

Wagner, G. E.

1984 The Corn and Cultivated Beans of the Fort Ancient Indians. The Missouri Archueologist 47:107-135.

Walker, C. P. and T. K. Perttula

2007a Remote Sensing at the Horace Cabe Site (4IBW 14). Caddo Archeology Journal 16:37-44.

2007b Geophysical Surveying at the Tallow Grove (4INA231), Foggy Fork (41NA235), and Beech Ridge (41NA242) sites. In Lake Naconiche Archeology, Nacogdoches County, Texas: Results of the Data Recovery Exoavations at Five Prehistoric Archeological Sites, edited by T. K. Perttula. 2 Vols. Report of Investigations No. 60 . Archeological \& Environmental Consultants, LLC, Austin.

Walker, C. P. and T. C. Schultz

2006 Magnetometer Survey and Results. In An Intensive Cultural Resources Survey and Remote Sensing and Geomorphological Investigations for the Bowie County Levee Realignment Project, Bowie County. Texas and Little River County, Arkansas, by S. A. Sundermeyer, J. T. Penman, and T. K. Perttula, pp. 158-168. Miscellaneous Reports, Report of Investigations No. 29. LopezGarcia Group, Dallas, Texas.

Walker, C. P. T. C. Schultz, D. G. Creel, D. Hudler, and S. M. Wilson

2003 Magnetometer Survey and Intrasite Structure of the George C. Davis Site in Northeast Texas. Paper presented at the 11 th East Texas Archeological Conference, Texarkana, Texas.

Walters, $M$.

2006 The Lake Clear (41SM243) Site and Crotalus horridus atricaudatus. Caddo Archeology Journal 15:5-39.

Walters, M. and P. Haskins

2000 The Bryan Hardy Site (41SM55), Smith County, Texas. Joumal of Northeast Texas Archaeology 12:1-26.

Walters, M., P. Haskins, D. H. Jurney, S. E. Goldborer, and T. K. Perttula

1984 Archeological Investigations at the Redwine Site (41SM193). Smith County, Texas. Joumal of Northeast Texas Archaeology 11:1-38.

Webb, C.H.

1963 The Smithport Landing Site: An Alto Focus Component in De Soto Parish, Louisiana. Bulletm of the Texas Archeological Society 34:143-187.

Weigand, P. C., G. Harbottle, and E. V. Sayre

1977 Turquoise sources and source analysis: Mesoamerica and the southwestem U.S.A. In Exchange Systems in Prelistory, edited by T. K. Earle and J. E. Ericson, pp. 15-34. Academic Press, New York.

Witt, A., Ir.

1960 Length and Weight of Ancient Freshwater Drum, Aplodinotws grumiens, Calculated from Otoliths Found in Indian Middens. Copeia 3:181-185 


\section{Appendix I, Ground Penetrating Radar Investigations at the Leaning Rock Site (41SM325)}

Velicia R. Bergstrom, John Ippolito, and Kent Schneider

INTRODUCTION

On March 25, 2005, a research team from the United States Department of Agriculture, Forest Service, conducted a shallow geophysics study using ground penetrating radar (GPR) at 4ISM325, The Leaning Rock site. The area of survey included a single $40 \times 40 \mathrm{~m}$ grid, with its southwest conner at N90 E60 (see Figure 1). The principal objectives of the GPR survey were to: (1) determine the utility of GPR at the site; (2) determine the location of unknown prehistoric structures or features; and (3) inform and guide subsequent excavation work in the area.

\section{GROUND PENETRATING RADAR}

Ground penetrating radar (GPR) has grown in popularity in usage on archeological sites (Conyers and Goodman 1997:11). GPR involves the observation of the reflected component of transmitted electromagnetic waves into the subsurface. The reflections, unlike that of acoustical waves, occur at the interfaces of materials of differing electrical conductivity or permittivity. The depth of penetration for radar waves is frequency dependent and the attenuation of the radar wave in the ground is rather quick compared to that of seismic waves: a few meters compared to kilometers.

As many, if not most, buried features of archeological interest are not deeply found, then GPR has utility in the search and characterization of these features. GPR is characterized as a WYSIWYG technique: what you see is what you get. The GPR output is a series of radar wavelet traces or scans produced on a chart recorder or computer sereen as an antenna is pulled across the ground surface. The radar wave perturbations can directly yield reffection depth, and the relative strength of the reflections, such that the form and location of a buried object or feature can be ascertained rather readily. If the velocity of the radar waves can be determined, then the conversion of travel-time, between the transmitter and receiver, of the reflected wave, can be converted to distance similar to that done in seismic studies. Indeed, the advanced processing of GPR data is done using software that was originally developed in the analysis of acoustical data. Mathematical protocols such as "stacking"" migration, and deconvolution are now commonly applied to GPR data in order to tease out the finest details as to stratigraphy and shape of subsurface reflectors or features.

The $40 \times 40 \mathrm{~m}$ area at the Leaning Rock site surveyed with GPR were done using a Geophysical Survey Systems Inc. (GSSI) Model SIR 2000 GPR unit composed of a digital console, cable, and a $400 \mathrm{MHz}$ antenna. Given a relatively non-conductive soil, where the radar wave's energy is not dissipated by refraction and absorption, up to $3 \mathrm{~m}$ below the antenna can be surveyed with GPR. For the present study, the following settings were used:

$\begin{array}{ll}\text { Time window: } & 60 \text { nanoseconds } \\ \text { Samples per scan: } & 512 \\ \text { Resolution: } & 8 \text { bits } \\ \text { Gain Points: } & -1,40,53,69,72\end{array}$




\section{DATA PROCESSING METHODS}

We present the various radar data sets in X-Y plots using GPR Slice, written by Dean Goodman, to produce amplitude slice maps at depths $Z$, displayed in nanoseconds (ns). The maps are amplitude displays with the intensity or presence of a buried feature inferred by the strength and shape of it on the respective displays. The plots of the GPR data are multi-level "slices" varying in depth of penetration as a function of travel-time in ns. The use of multi-level slices of these data allows the observer to get a sense of the depth and shape of the subsurface features and their co-occurrence in comparable plots.

\section{DISCUSSION OF RESULTS}

The data was collected using zigzag lines spaced $0.5 \mathrm{~m}$ apart along the $\mathrm{Y}$ coordinate in a XY grid where $\mathrm{X}$ equals $40 \mathrm{~m}$ and $Y$ equals $40 \mathrm{~m}$. Marks were made every $1 \mathrm{~m}$ along each $Y$ line. The raw data was downloaded onto a computer where 20 4-ns slice maps were created (Figure 48). From this data, further refinements were made via interpolations and application of low pass filters to produce revised slice maps that better display the data indicative of the presence of anomalies in the area (Figure 49).

Figure 50 depicts the location of Unit 1 within a midden area at Leaning Rock. To the east-southeast of this area is of high interest, likely indicative of soil changes in this area, and may in fact be representative of the midden area. To the west of this unit there is another area of interest, it being somewhat circular in nature (see Figure 50). This area lies between E78-85 and N97-105. There are other areas that depict possible anomalies and these should eventually be evaluated as well, although they may be geologic in nature.

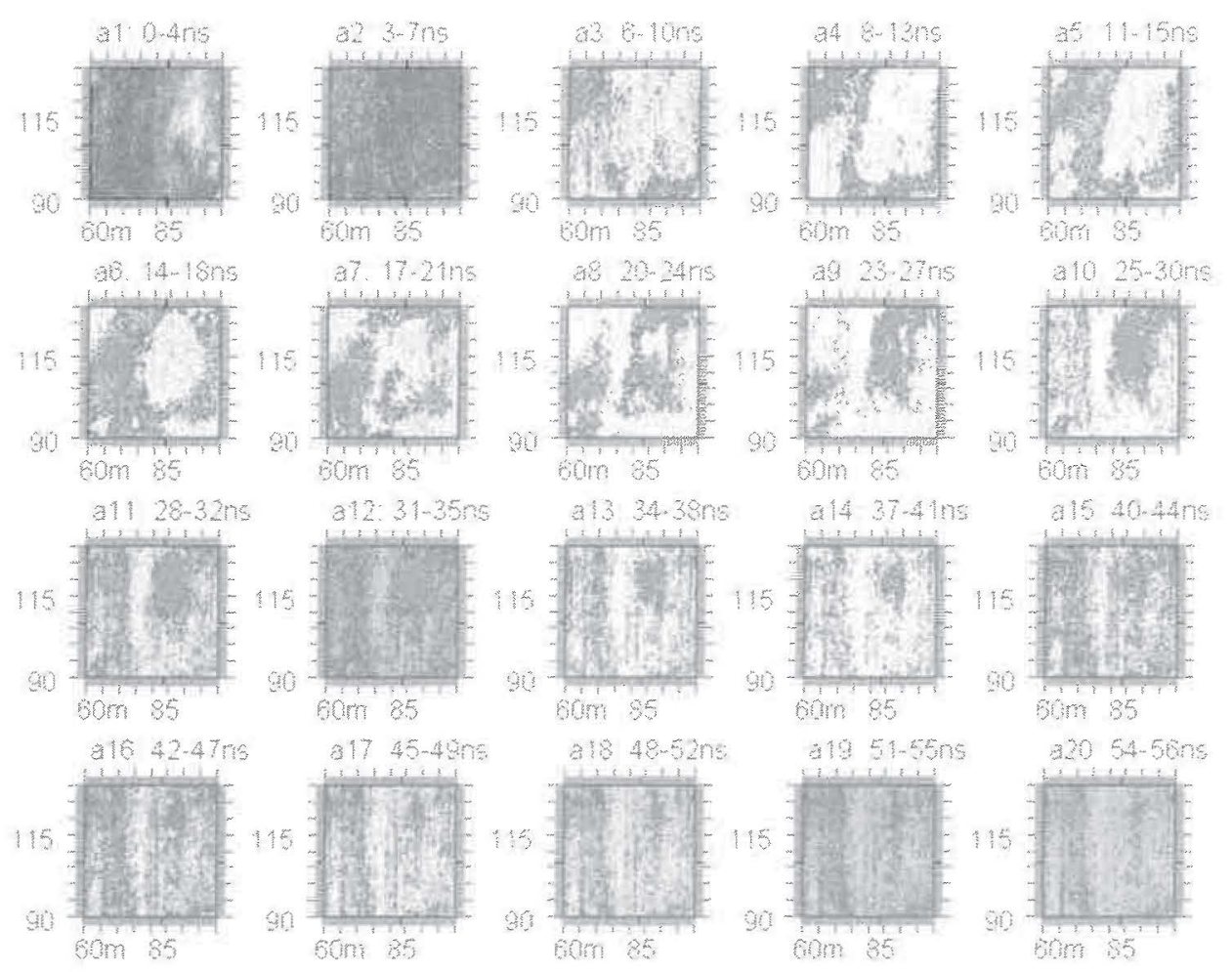

Figure 48. 20 4-nanosecond maps. 


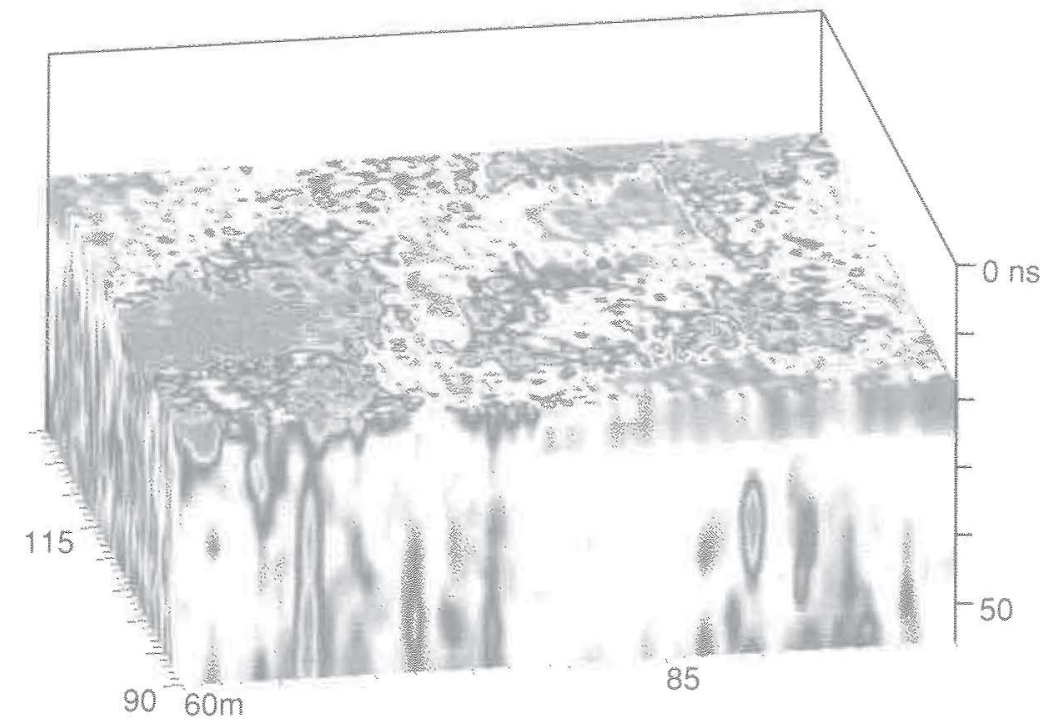

Figure 49. 3D results at $19 \mathrm{~ns}$ in depth, facing north.

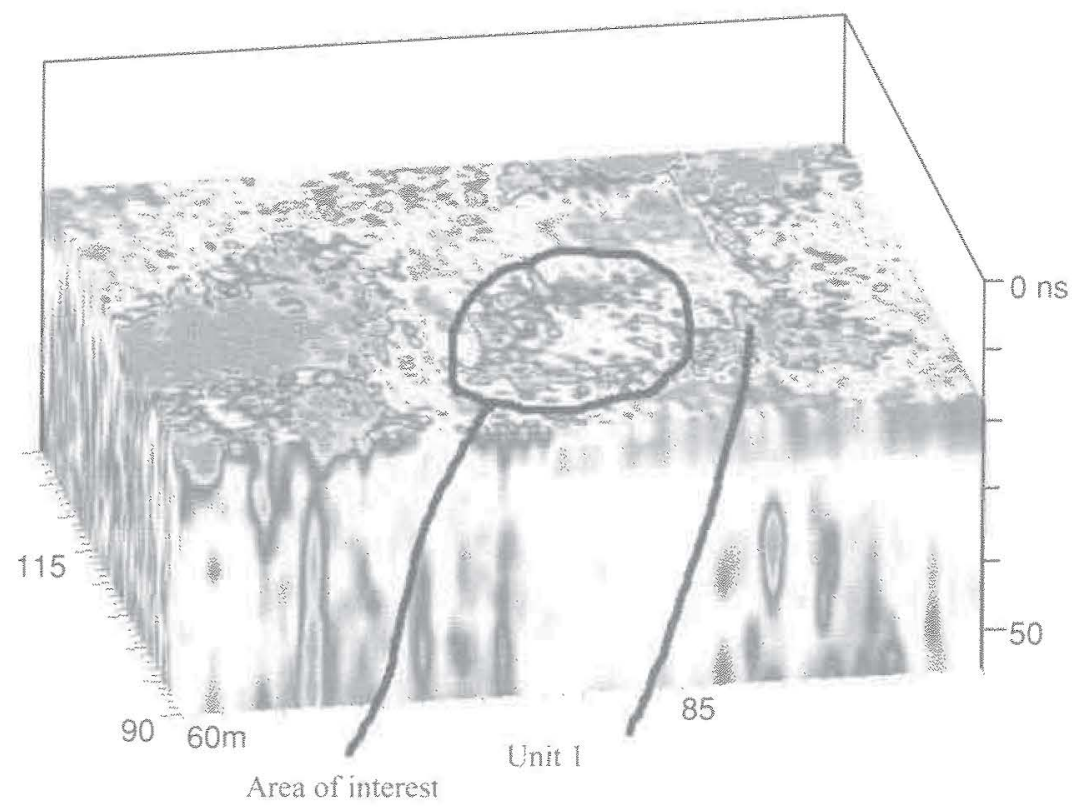

Figure 50. Areas of interest in the GPR data, facing north.

\section{ACKNOWLEDGEMENTS}

We would like to thank Mark Walters and Bo Nelson for having the foresight to continue our studies and research into GPR applications and for making this site available for such an endeavor.

\section{REFERENCES CITED}

Conyers, L. B. and D. Goodman

1997 Ground Penetromg Radar. An hntwduction for Ardeologists. AltaMira Press, Walnut Creek. California. 


\title{
Appendix II, Mussel Descriptions from the Leaning Rock Site (41SM325)
}

\author{
Jesse Todd
}

\section{Gastropoda}

Feature 1

$24.33 \mathrm{~cm}$

Helicina orbiculata

TU 12

$20-30 \mathrm{~cm}$

Glyphylinia (Retinella) indentata

Linisa (Polygyra) lexasiana

Helicina orbiculata

Identifiable Mollusca

TU

$30-40 \mathrm{~cm}$

$50-60 \mathrm{~cm}$

$60 \mathrm{~cm}$

TU $3 \quad 20-30 \mathrm{~cm}$

$30-40 \mathrm{~cm}$

TU $6 \quad 30-40 \mathrm{~cm}$

TU $12 \quad 20-30 \mathrm{~cm}$

$30-40 \mathrm{~cm}$

$50-60 \mathrm{~cm}$

Feature 5

Lampsilis teres right valve

$\mathrm{h}=47.7 \mathrm{~mm} ; 1=93.4 \mathrm{~mm}$

Quadrula mortoni left valve

$\mathrm{h}=31.1 \mathrm{~mm} ; \mathrm{l}=35.1 \mathrm{~mm}$

Tritogonia vernucosa left valve

$\mathrm{h}=54.9 \mathrm{~mm} ; \mathrm{I}=81.7 \mathrm{~mm}$

either Quadrula apiculata or Tritogonia verrucosa $10 \%$ present right valve

Tritogonia verrucosa right valve (30\%) present

Quadrula apiculata left valve

$\mathrm{h}=40.8 \mathrm{~mm} ; \mathrm{l}=56.9 \mathrm{~mm}$

Tritogonia vermucosa left valve - very weathered $\mathrm{h}=48 \mathrm{~mm}: \mathrm{I}=76.7 \mathrm{~mm}$

Fusconaia flava right valve

$\mathrm{h}=32.8 \mathrm{~mm} ; \mathrm{l}=$ unknown $(80 \%$ present $)$-- very

weathered

Fusconaia flava right valve

$\mathrm{h}=34.0 \mathrm{~mm} ;=41.7 \mathrm{~mm}$

Have thin fragment similar to Lumpsilis sp. or could be Leptodea fragilis or Potamilus ohioensis very thin

Lampsilishydiana left valve $\mathrm{h}=22.2 \mathrm{~mm} ; \mathbf{l}=35.6 \mathrm{~mm}$

$60-70 \mathrm{~cm} \quad$ Feature 5 Tritogonia verncosa left valve $\mathrm{h}=32.2 \mathrm{~mm} ; \mathrm{I}=51.0 \mathrm{~mm}$

Lampsilis sp. indet. $\quad 40 \%$ present

$80-90 \mathrm{~cm} \quad$ Feature 5 Fusconaia fava right valve $\mathrm{h}=31.1 \mathrm{~mm} \mathrm{I}=37.4 \mathrm{~mm}$

$75-85 \mathrm{~cm} \quad$ Feature 5 Fusconaia flava right valve ( $80 \%$ present) nicked along bottom

\section{Shell Fragments}

TU1 $\quad 15-24 \mathrm{~cm}$

unburned - some gray (heated)* 
Shell Tragments, continued

$20-30 \mathrm{~cm}$

$30-40 \mathrm{~cm}$

$40-50 \mathrm{~cm}$

$50 \sim 60 \mathrm{~cm}$

$60-70 \mathrm{~cm}$

TU $3 \quad 20-30 \mathrm{~cm}$

$30-40 \mathrm{~cm}$

$40-50 \mathrm{~cm}$

TU $4 \quad 20-30 \mathrm{~cm}$

$30-40 \mathrm{~cm}$

$40-50 \mathrm{~cm}$

TU5 $31.30 \mathrm{~cm}$

$30-40 \mathrm{~cm}$

TU7 $20-30 \mathrm{~cm}$

TU $6 \quad 30-40 \mathrm{~cm}$

$30-40 \mathrm{~cm}$

TU $8 \quad 10-20 \mathrm{~cm}$

$20-30 \mathrm{~cm}$

$30-40 \mathrm{~cm}$

TU $920-30 \mathrm{~cm}$

$30-40 \mathrm{~cm}$

TU 9A $\quad 30-40 \mathrm{~cm}$

TU $10 \quad 30-40 \mathrm{~cm}$

$40-50 \mathrm{~cm}$

TU $11 \quad 20-30 \mathrm{~cm}$

$50-88 \mathrm{~cm}$

TU 12

$10-20 \mathrm{~cm}$

$20-30 \mathrm{~cm}$

$30-40 \mathrm{~cm}$

$40-50 \mathrm{~cm}$

$50-60 \mathrm{~cm}$

$60-70 \mathrm{~cm}$

$75-85 \mathrm{~cm}$

$80-90 \mathrm{~cm}$

TU 13

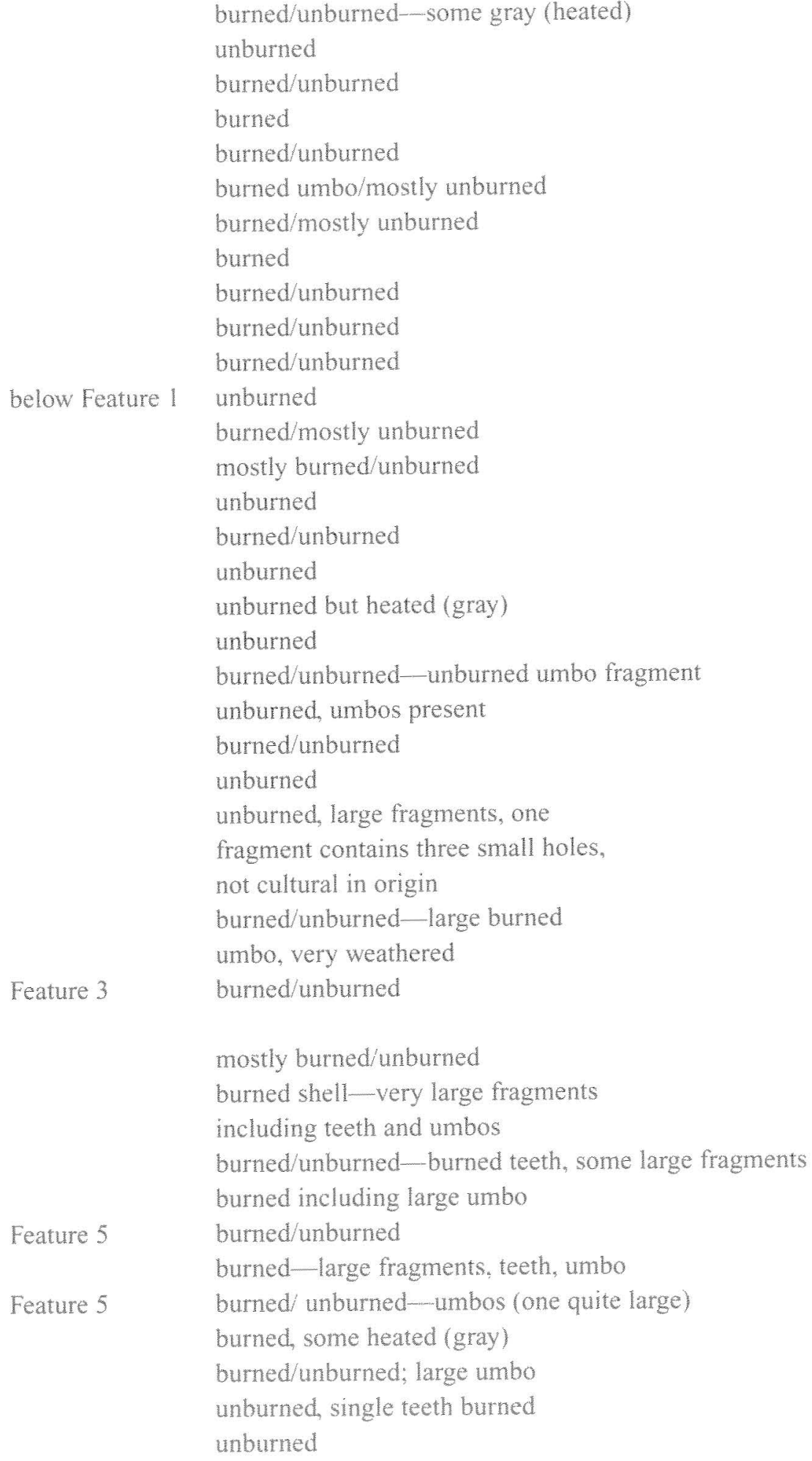

Feature 3

* some of the unbumed mussel shell is probably heated because of its gray color: bumed shell is dark gray to black. 